\title{
ISSN 2072-7607
}

Министерство науки и высшего образования Российской Федерации

Федеральное государственное бюджетное

образовательное учреждение высшего образования

«Рязанский государственный университет имени С.А. Есенина»

\section{ИНОСТРАННЫЕ ЯЗЫКИ \\ В ВЫСШЕЙ ШКОЛЕ}

Научный журнал

Выпуск 2 (57)

Рязань 2021 


\section{УЧРЕДИТЕЛЬ}

Федеральное государственное бюджетное образовательное учреждение высшего образования «Рязанский государственный университет имени С. А. Есенина»

Журнал зарегистрирован Федеральной службой по надзору в сфере связи, информационных технологий и массовых коммуникаций (Роскомнадзор) 20 марта 2018 г. Регистрационный номер ПИ № ФС77-72456

\section{РЕДАКЦИОННЫЙ СОВЕТ}

Я. М. Колкер, главный редактор, канд. пед. наук, доц., проф. каф. лингвистики и межкультурной коммуникации Рязанского государственного университета имени С. А. Есенина,

Е. С. Устинова, заместитель главного редактора, канд. пед. наук, доц. (Рязанский государственный университет имени С. А. Есенина),

С. Ю. Потапова, д-р филол. наук, проф. (центр немецкого языка - партнер Гёте-Института, Международная академия бизнеса и новых технологий, Ярославль),

В. Н. Степанов, д-р филол. наук, проф. (Международная академия бизнеса и новых технологий, Ярославль)

\section{РЕДАКЦИОННАЯ КОЛЛЕГИЯ}

Н. А. Ахренова, д-р филол. наук, доц. (Государственный социально-гуманитарный университет, Коломна)

В. Н. Бабаян, д-р филол. наук, доц. (Ярославское высшее военное училище ПВО),

Ван Цзиньлин, д-р филол. наук, проф. (Чанчуньский университет, Чанчунь, Китай),

Л. Г. Викулова, д-р филол. наук, проф. (Московский городской педагогический университет),

А. Н. Гордей, д-р филол. наук, проф. (Минский государственный лингвистический университет, Минск, Беларусь),

Г.-Г. Дрёссигер, д-р филол. наук, проф. (Каунасский филиал Вильнюсского университета, Литва),

С. Т. Золян, д-р филол. наук, проф. (Институг философии и права Национальной академии Армении, Ереван, Армения),

А. А. Колесников, д-р пед. наук, доц. (Рязанский государственный университет имени С. А. Есенина),

Т. Я. Кузнецова, д-р филол. наук, проф. (Северный (Арктический) федеральный университет, Архангельск),

Е. Г. Логинова, канд. филол. наук, доц. (Рязанский государственный университет имени С. А. Есенина),

Л. Н. Лунькова, д-р филол. наук, доц. (Государственный социально-гуманитарный университет, Коломна),

Альберто Манко, д-р филол. наук, доц. (Университет L’Orientale, Неаполь, Италия),

Е. Л. Марьяновская, канд. пед. наук, доц. (Рязанский государственный университет имени С. А. Есенина),

А. Д. Петренко, д-р филол. наук, проф. (Институг иностранной филологии Крымского федерального университета имени

В. И. Вернадского, Симферополь),

А. М. Поликарпов, д-р филол. наук, проф. (Северный (Арктический) федеральный университет, Архангельск),

В. Г. Решетов, д-р филол. наук, проф. (Рязанский государственный университет имени С. А. Есенина),

А. А. Решетова, д-р филол. наук, доц., проф. каф. литературы (Рязанский государственный университет имени С. А. Есенина),

T. С. Серова, д-р пед. наук, проф. (Пермский государственный технический университет),

О. В. Соколова, д-р филол. наук, старший научный сотрудник (Институг языкознания РАН, Москва),

В. В. Фещенко, канд. филол. наук, старший научный сотрудник (Институт языкознания РАН, Москва),

Д. М. Храбскова, канд. филол. наук, доц. (Институг иностранной филологии Крымского федерального университета имени В. И. Вернадского, Симферополь),

О. Г. Чупрына, д-р филол. наук, проф. (Московский городской педагогический университет, Московский педагогический госудаственный универститет),

И. М. Шеина, канд. филол. наук, доц., проф. каф. восточных языков и методики их преподавания (Рязанский государственный университет имени С. А. Есенина).

Журнал выходит 4 раза в год.

С 01.12.2015 г. входит в перечень российских рецензируемых научных изданий, в которых должны быть опубликованы основные научные результаты диссертаций на соискание ученой степени кандидата наук, на соискание ученой степени доктора наук.

Адрес и телефон редакции: 390000, г. Рязань, ул. Свободы, д. 46;

тел.: (4912) 21-57-23, e.ustinova@365.rsu.edu.ru

Ссылка на журнал «Иностранные языки в высшей школе» обязательна.

Редакция не всегда разделяет мнение авторов.

Подписаться на журнал можно в любом отделении связи.

Подписной индекс издания № 55170 в каталоге «Объединенный каталог Пресса России»

(C) Федеральное государственное бюджетное образовательное учреждение высшего образования «Рязанский государственный университет имени С. А. Есенина», 2021

(C) «Иностранные языки в высшей школе», 2021 


\section{СОДЕРЖАНИЕ}

\section{Раздел I \\ Теоретические вопросы семантики}

Гордей А. $\mathrm{H}$.

Семантическая разметка события и её отображение средствами

китайского и русского языков 5

Степанов В. Н.

Концепты Spiel (игра) и Kampf (борьба) в структуре концептосферы силы

в немецкой философской традиции

\section{Раздел II}

Семантика знаков в дискурсе: когнитивный аспект

Голубкова Е. Е., Таймур М. П.

Метафорическая креативность в дорожных знаках

Захаркив Е. В.

Ресемантизация дискурсивных слов в современной русско- и англоязычной поэзии 42

Орлова О. С.

Кодирование денотата в эвфемизмах и загадках на тему беременности и рождения

\section{Раздел III \\ Влияние условий общения на дискурс}

Бабаян В. $\boldsymbol{H}$.

$\mathrm{O}$ «переключении языкового кода» и смене темы разговора в диалогическом дискурсе терциарной речи 68

Калашникова Е. А., Соколова Г. А., Зимарин Д. Е.

Стилизация устной немецкой речи в современном медийном дискурсе 79

\section{Раздел IV \\ Русская классика и проблемы ее перевода}

Запруднова $A$. $A$.

Механизмы интертекстуальности и способы их передачи при переводе с русского языка на китайский язык (на примере отрывков из произведений А.П. Чехова).

Ли Чуньюй

Перевод и изучение творчества И. А. Крылова в Китае 99

\section{Раздел V}

\section{К 80-летию начала Великой Отечественной войны}

Колкер Я. М., Устинова Е. С.

Выразительность текста в парадигме «поэтика — поэзия — перевод» 108

Требования к публикациям и правила представления рукописей авторами 118 


\section{TABLE OF CONTENTS}

\section{Part I \\ Theoretical Issues of Semantics}

\section{Hardzei, Aliaksandr}

Semantic Markup of the Event and its Display by Means of the Chinese and Russian Languages 5

Stepanov, Valentin

The Concepts of Spiel (playing) и Kampf (struggle) within the Structure of the Conceptual Sphere of Power in the German Philosophic Tradition

\section{Part II}

Semantic Challenges of Sign Symbolism: The Cognitive Approach

Golubkova Ekaterina, Taymour Maria

Metaphorical Creativity in Road Signs

Zakharkiv, Ekaterina

Resemantization of Discourse Markers in Contemporary Russo- and Anglophone Poetry

Orlova, Olga

Denotation Coding in Euphemisms and Riddles about Pregnancy and Birth

\section{Part III}

The Influence of the Communicative Situation on Discourse

\section{Babayan, Vladimir}

On 'Code Switching' and Changing the Conversation Topic in a Tertiary

Speech Dialogical Discourse

Kalashnikova, Elena; Sokolova, Galina; Zimarin, Dmitrij

Stylization of Oral German Speech in Modern Media Discourse

\section{Part IV}

\section{Russian Classical Literature: a Translator's View}

\section{Zaprudnova, Anastasia}

Mechanisms of Intertextuality and Means of Rendering Them in Translation from Russian into Chinese (illustrated by excerpts from A. Chekhov's works).

\section{Li Chunyu}

Translation and study of I. A. Krylov's Works in China

\section{Part V}

80 Years Ago: Commemorating the Beginning of the Great Patriotic War

Kolker, Yakov; Ustinova, Elena

The Affective Aspect of the "Poetics — Poetry — Translation" Paradigm 108

Requirements to the papers submitted (in Russian) *

\footnotetext{
* Available in English at: http://fljournal.rsu.edu.ru/en
} 


\title{
РАЗДЕЛ I \\ ТЕОРЕТИЧЕСКИЕ АСПЕКТЫ ЛЕКСИЧЕСКОЙ СЕМАНТИКИ
}

Иностранные языки в высшей школе. 2021. № 2 (57). С. 5-26.

Foreign Languages in Tertiary Education. 2021;2(57):5-26.

Научная статья

УДК [811.581’37’322.2+811.161.1'37’322.2]:004.8

DOI: 10.37724/RSU.2021.57.2.001

\section{Семантическая разметка события и её отображение средствами китайского и русского языков}

\author{
Александр Николаевич Гордей \\ Минский государственный лингвистический университет, Минск, Беларусь \\ alieks2001@yahoo.com
}

Аннотация. На основе третьей редакции второй версии Теории автоматического порождения архитектуры знаний (ТАПАЗ-2) предложен новый подход к семантической разметке события и формализации синтаксиса китайских и русских предложений, а также намечены пути решения проблемы автоматического определения семантической эквивалентности текстовых документов и заимствования научных идей ${ }^{1}$.

Ключевые слова: комбина́торная семантика, сематическая разметка, семантический падеж, семантический классификатор, граф знаний, ролевой лист индивидов, субъект, объект, акция, макропроцесс, специализированный процесс, модель мира, ТАПАЗ-алгебра, ТАПАЗ-юнит.

Для цитирования: Гордей А. Н. Семантическая разметка события и её отображение средствами китайского и русского языков // Иностранные языки в высшей школе. 2021. № 2 (57). C. 5-26. DOI: 10.37724/RSU.2021.57.2.001.

Original article

\section{Semantic Markup of the Event and its Display by Means of the Chinese and Russian Languages}

\author{
Aliaksandr Hardzei \\ Minsk State Linguistic University, Minsk, Belarus \\ alieks2001@yahoo.com
}

Abstract. On the basis of the third edition of the second version of Theory for Automatic Generation of Knowledge Architecture (TAPAZ-2), a new approach to the semantic markup of an event and the syntax formalization of Chinese and Russian sentences is proposed, as well as ways of solving the problem of automatically identifying the semantic equivalence of text documents and borrowing scientific ideas.

Keywords: combinatory semantics, semantic markup, semantic case, semantic classifier, knowledge graph, role list of individs, subject, object, action, macroprocess, specialized process, world model, TAPAZalgebra, TAPAZ-unit.

${ }^{1}$ В статье развиваются положения, сформулированные автором (см.: Hardzei A. Plagiarism Problem Solving Based on Combinatory Semantics // Communications in Computer and Information Science (CCIS). Switzerland : Springer Nature Switzerland AG, 2020. Vol. 1282. Pp. 176-197. URL : https://link.springer.com/book/ 10.1007\%2F978-3-030-60447-9).

(C) Гордей А. Н., 2021 
For citation: Hardzei A. Semantic Markup of the Event and its Display by Means of the Chinese and Russian Languages. Foreign Languages in Tertiary Education. 2021;2(57):5-26 (In Russ.). DOI: 10.37724/ RSU.2021.57.2.001.

\author{
O, сколько нам открытий чудных \\ Готовят просвещенья дух, \\ И опыт, сын ошибок трудных, \\ И гений, парадоксов друг, \\ И случай, бог изобретатель.
}

А. С. Пушкин

\section{Введение}

Практически одновременно с появлением Интернета в американском научном сообществе родилась идея построения алгоритмов поиска релевантной информации по строго определенным семантическим правилам. В 2001 году создатель Всемирной паутины и нынешний глава консорциума W3C T. Бернерс-Ли в соавторстве с Дж. Хендлер и О. Лассила опубликовал в журнале "Scientific American" программную статью «Семантический вэб: понятная компьютерам новая форма веб-контента вызовет революцию новых возможностей» [Berners-Lee, Hendler, Lassila, 2001]. Основной упор в статье был сделан на развитии семантических технологий поиска и обработки информации в Интернете и с помощью Интернета: «На сегодняшний день Всемирная паутина развивается, прежде всего, как средство снабжения людей документами, нежели информацией, которой можно управлять автоматически. Дополняя веб-страницы данными, предназначенными для компьютеров, и добавляя документы исключительно для компьютеров, мы превратим Сеть в семантическую. Компьютеры найдут значение семантических данных по гиперссылкам на определения ключевых терминов и правил логического оперирования с ними. Полученная в результате инфраструктура будет стимулировать разработку автоматизированных веб-сервисов как высокофункциональных агентов. Обычные пользователи станут составлять страницы семантической паутины и добавлять новые определения и правила, используя готовое программное обеспечение, которое поможет с семантической разметкой» [Там же, с. 36].

Фактически авторы предлагали альтернативу набирающим популярность в искусственном интеллекте статистическим методам обработки информации: «Семантический вэб привнесёт структуру в содержимое веб-страниц, создав среду, в которой программные агенты, перемещающиеся от страницы к странице, смогут легко выполнять для пользователей сложные задачи. Такой агент, оказавшись на веб-странице клиники, будет знать не только об имеющихся на ней ключевых словах типа “лечение”, “медицина”, “физиотерапия”, “терапия” (как это кодируется сегодня), но и о том, что, например, доктор Хартман работает в этой клинике по понедельникам, средам и пятницам, что заявка подаётся с указанием даты в формате год-месяц-день и резервирует время приёма. Всё это семантическая сеть будет “знать" без обращения к искусственному интеллекту в духе Хэла-2001 или С-3РО из “Звёздных войн”» [Berners-Lee, Hendler, Lassila, 2001, с. 37]. И далее: «Для функционирования семантической сети компьютеры должны иметь доступ к структурированным коллекциям информации и наборам правил вывода, которые они могут использовать для проведения автоматизированных рассуждений. Специалисты в области искусственного интеллекта изучали такие системы задолго до появления Интернета. Представление знаний, как часто называют эту технологию, в настоящее время находится в состоянии, сравнимом с состоянием гипертекста до появления Интернета: это явно хорошая идея, и уже есть некоторые очень хорошие демонстрационные образцы, но они ещё не изменили мир. Они содержат семена для важных приложений, полная реализация потенциала которых возможна лишь путём их объединения в единую глобальную систему» [Там же]. 
Поскольку с помощью трансформационной грамматики Н. Хомского, на которой были построены контекстно-зависимые и контекстно-свободные грамматики, ставшие основой для объектно-ориентированных языков программирования высшего уровня типа Java, C++, C\# и т. д., удавалось лишь с переменным успехом формализовывать синтаксис, но никак не семантику, взгляды американских учёных обратились к семантическим падежам Ч. Филлмора [Филлмор, 1981a, 1981б, 1983, 1988 ; Fillmore, 1976, 1982 ; Fillmore, Atkins, 1994], ранним работам Р. Джекендоффа [Jackendoff, 1972, 1977] и «тэта-матрицам» T. Стоуэлла [Stowell, 1981]. Любопытно, что при этом на второй план оказалась отодвинутой формальная грамматика Р. Монтегю [Montague, 1974] с её PTQ (Proper Treatment of Quantification in ordinary English) и лямбда-абстракцией, хотя именно эта грамматика в ряде случаев обобщала в терминах математической логики достижения генеративной семантики Дж. Лакоффа [Lakoff, 1968] и интерпретационной семантики Р. Джекендоффа. Любопытно также и то, что за скобки был вынесен и семантический синтаксис Л. Теньера [Tesnière, 1959] с глагольными узлами из актантов и сирконстантов, фактически - аналогов семантических падежей Ч. Филлмора (труды Л. Теньера вышли в свет на 30 лет раньше, чем падежная грамматика Ч. Филлмора, а монография В. В. Мартынова «Кибернетика. Семиотика. Лингвистика» с прототипом универсального семантического кода (УСК) и описанием ролей знаков в ядерной семантической цепочке субъект - акиия - объект $(S A O)-$ на 2 года [Мартынов, 1966]. Отметим, что в настоящее время лингвистика располагает только одной синтетической (последовательно дедуктивной и процедуральной) моделью языка - грамматикой Панини, датируемой V веком до н. э., в которой с помощью 3959 кратких сутр (правил) исчерпывающим образом описано порождение, построение и преобразование всех единиц санскрита, начиная с фонетико-фонологического уровня и заканчивая семантикосинтаксическим [Ashtadhyayi or Sutrapath of Panini ; Топоров, 1961 ; Волошина, 2010]. До сих пор непонятно, какие формализмы положены в основание столь точного описания естественного языка и каким образом удалось достичь этого в столь давние времена, как, например, по сей день не неизвестно, по какой математической модели собраны гексаграммы древнекитайской книги «Перемен» 易經 (Изцин), анализ которых привёл Лейбница к идее двоичного исчисления, ставшего основой современной вычислительной техники, ясно одно - европейское языкознание, прежде всего французское, в скрытом виде заимствовало ряд положений грамматики Панини, в частности о том, что падеж является не столько морфологической, сколько семантико-синтаксической категорией - грамматику Панини основоположники структурной лингвистики не могли не знать, кафедры санскритологии были во многих европейских университетах. Однако подчеркнём, что семантические падежи были важным, но не единственным достижением Панини. Они органично вписывались во всю архитектуру грамматики, будучи выделенными с помощью некоторой алгебры. Без неё можно, хотя и с трудом, переводить грамматику Панини с одного языка на другие, но невозможно описывать другие языки, как Панини: формализация языков и перевод - задачи всё же разные. Поиском такой алгебры и занялся профессор В. В. Мартынов.

В период с 1974 по 2001 год были опубликованы 6 версий универсального семантического кода (УСК) [Мартынов, 1974, 1977, 1984, 1988, 2001 ; Martynov, 1995]. В версиях совершенствовался алгебраический аппарат, предлагался уточнённый список «несуществующих», по мнению Т. Винограда, исходных семантических примитивов ${ }^{2}$ и тем самым

${ }^{2}$ «Язык есть процесс коммуникации между людьми, и он сложнейшим образом переплетён со знаниями о мире, которыми эти люди располагают. Знания эти не являются простой сводкой определений и аксиом полных, чётких и последовательных. Скорее, они представляют собой совокупность понятий, выработанных для того, чтобы манипулировать мыслями. На самом деле они несовершенны, в сильной степени избыточны и часто непоследовательны. Не существует такого замкнутого множества «примитивов», исходя из которого можно было бы определить всё, что угодно. Определения «циркулярны», циклически связаны между собой, значения каждого из них зависит от других понятий» [Виноград, 1976, с. 48]. 
сужался перечень задач по оснащению компьютера энциклопедическими базами знаний. В окончательном виде данный перечень насчитывал пять пунктов:

«1. Исчислить примитивы, т. е. семантически неразложимые ключевые слова и правила их комбинаторики.

2. Установить необходимый и достаточный набор формальных характеристик, составляющих «словарную статью».

3. Определить набор семантических операций, позволяющий исчислять предметные области любого вида (выделено нами. - А. Г.).

4. Выработать эвристические правила обучения работе с такой системой.

5. Разработать систему взаимных отсылок на семантической основе» [Мартынов, 2001, c. 42].

Достигнутые успехи уже в 1993 году позволили сотрудникам научно-исследовательского центра «Семантика» под руководством В. В. Мартынова приступить к интенсивному поиску способов расширения базового семантического классификатора до энциклопедических баз знаний. В 1994 году впервые нами была предложена процедура исчисления предметных областей в виде особо ориентированного графа ранжирования сложных цепочек [Гордей, 1995]. Применение процедуры потребовало установления одно-однозначного (векторного) перехода между макропроцессами в базовом семантическом классификаторе и привело к созданию теории автоматического порождения архитектуры знаний (ТАПАЗ), основу которой составили формализованная теория, семантический двойник, таблица семантических примитивов (семантический классификатор макропроцессов), алгоритм ролей индивидов (ролевой лист индивидов) и граф поиска специализированных процессов через макропроцессы (граф знаний) [Гордей, 1998а, 1998б] (рис. 1).

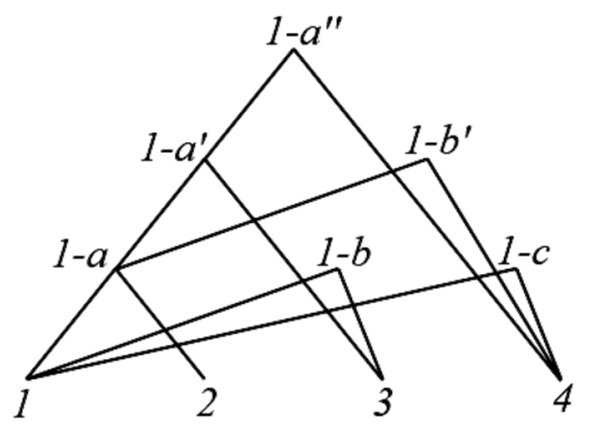

Puc. 1. Граф семантического классификатора (граф знаний ТАПАЗ)

1 - активный макропроцесс; 2, 3, 4 - уточняющие макропроцессы; 1-a, 1-b, 1-c - производные процессы с $1-a$ в качестве активного производного процесса; $1-a^{\prime}$ и $1-b^{\prime}-$ производные процессы второй степени с $1-a^{\prime}$ в качестве активного производного процесса второй степени; $1-a^{\prime \prime}-$ активный производный процесс третьей степени

Например, макропроцесс «реформование» можно рассматривать как множество, а процессы «лечить», «ремонтировать», «настраивать» — как его подмножества. Такой подход позволяет выявить изоморфизм предметных областей и создать структуру знаний с ячейками, заполненными специфическими для каждой предметной области процессами, сопряжёнными с макропроцессами семантического классификатора ТАПАЗ [Hardzei, Udovichenko, 2019].

Новая версия теории автоматического порождения архитектуры знаний ТАПАЗ-2 отличается от предыдущей упрощением алгебраического аппарата, увеличением правил интерпретации типовых совмещений индивидов и минимизацией семантических исчислений. Количество операций на цепочках семантического кода сокращено до двух. Теперь это алгебра вида

$$
\mathrm{A}=\langle\mathrm{M}, *,-\rangle
$$


где $M$ - множество элементов, * (звёздочка) - операция совмещения, - (крышка) - операция продления (детальное описание новой версии ТАПАЗ-алгебры см.: [Hardzei, 2017]).

Примеры формул ТАПАЗ:

$$
\begin{aligned}
& (((((((((((((\mathrm{X} * \overline{\mathrm{X}}) * \overline{\overline{\mathrm{Y}}}) * \overline{\mathrm{Y}}) * \mathrm{Y}) * \overline{\mathrm{Y}}) * \overline{\overline{\mathrm{Z}}}) * \overline{\mathrm{Z}}) * \mathrm{Z}) * \overline{\mathrm{Z}}) * \overline{\overline{\mathrm{Z}}}) * \overline{\overline{\mathrm{W}}}) * \overline{\mathrm{W}}) * \mathrm{~W}) * \overline{\mathrm{W}}) * \overline{\overline{\mathrm{W}}} ; \\
& ((((((((((((\mathrm{X} * \overline{\mathrm{X}}) * \overline{\overline{\mathrm{X}}}) * \overline{\overline{\mathrm{Y}}}) * \overline{\mathrm{Y}}) * \mathrm{Y}) * \overline{\mathrm{Y}}) * \overline{\overline{\mathrm{Z}}}) * \overline{\mathrm{Z}}) * \mathrm{Z}) * \overline{\mathrm{Z}}) * \overline{\overline{\mathrm{W}}}) * \overline{\mathrm{W}}) * \mathrm{~W}) * \overline{\mathrm{W}}) * \overline{\overline{\mathrm{W}}} \\
& (((((((((((((\mathrm{X} * \overline{\mathrm{X}}) * \overline{\overline{\mathrm{Y}}}) * \overline{\mathrm{Y}}) * \mathrm{Y}) * \overline{\mathrm{Y}}) * \overline{\overline{\mathrm{Z}}}) * \overline{\mathrm{Z}}) * \mathrm{Z}) * \overline{\mathrm{Z}}) * \overline{\overline{\mathrm{W}}}) * \overline{\mathrm{W}}) * \mathrm{~W}) * \overline{\mathrm{W}}) * \overline{\overline{\mathrm{W}}}) * \overline{\mathrm{W}} \text {; } \\
& ((((((((((((((\mathrm{X} * \overline{\mathrm{X}}) * \overline{\overline{\mathrm{Y}}}) * \overline{\mathrm{Y}}) * \mathrm{Y}) * \overline{\mathrm{Y}}) * \overline{\overline{\mathrm{Y}}}) * \overline{\overline{\mathrm{Z}}}) * \overline{\mathrm{Z}}) * \mathrm{Z}) * \overline{\mathrm{Z}}) * \overline{\overline{\mathrm{W}}}) * \overline{\mathrm{W}}) * \mathrm{~W}) * \overline{\mathrm{W}}) * \overline{\overline{\mathrm{W}}}) * \overline{\mathrm{W}} \text {; } \\
& (((((((((((((\mathrm{X} * \overline{\mathrm{X}}) * \overline{\overline{\mathrm{Y}}}) * \overline{\mathrm{Y}}) * \mathrm{Y}) * \overline{\mathrm{Y}}) * \overline{\overline{\mathrm{Z}}}) * \overline{\mathrm{Z}}) * \mathrm{Z}) * \overline{\mathrm{Z}}) * \overline{\overline{\mathrm{Z}}}) * \overline{\overline{\mathrm{W}}}) * \overline{\mathrm{W}}) * \mathrm{~W}) * \overline{\mathrm{W}}) * \overline{\overline{\mathrm{W}}}) * \overline{\mathrm{W}} \text {; } \\
& ((((((((((((((\mathrm{X} * \overline{\mathrm{X}}) * \overline{\overline{\mathrm{X}}}) * \overline{\overline{\mathrm{Y}}}) * \overline{\mathrm{Y}}) * \mathrm{Y}) * \overline{\mathrm{Y}}) * \overline{\overline{\mathrm{Z}}}) * \overline{\mathrm{Z}}) * \mathrm{Z}) * \overline{\mathrm{Z}}) * \overline{\overline{\mathrm{W}}}) * \overline{\mathrm{W}}) * \mathrm{~W}) * \overline{\mathrm{W}}) * \overline{\overline{\mathrm{W}}}) * \overline{\mathrm{W}} \text {; } \\
& ((((((((((((((\mathrm{X} * \overline{\mathrm{X}}) * \overline{\overline{\mathrm{Y}}}) * \overline{\mathrm{Y}}) * \mathrm{Y}) * \overline{\mathrm{Y}}) * \overline{\overline{\mathrm{Z}}}) * \overline{\mathrm{Z}}) * \mathrm{Z}) * \overline{\mathrm{Z}}) * \overline{\overline{\mathrm{W}}}) * \overline{\mathrm{W}}) * \mathrm{~W}) * \overline{\mathrm{W}}) * \overline{\overline{\mathrm{W}}}) * \overline{\mathrm{W}}) * \mathrm{~W} \text {; } \\
& (((((((((((((((\mathrm{X} * \overline{\mathrm{X}}) * \overline{\overline{\mathrm{Y}}}) * \overline{\mathrm{Y}}) * \mathrm{Y}) * \overline{\mathrm{Y}}) * \overline{\overline{\mathrm{Y}}}) * \overline{\overline{\mathrm{Z}}}) * \overline{\mathrm{Z}}) * \mathrm{Z}) * \overline{\mathrm{Z}}) * \overline{\overline{\mathrm{W}}}) * \overline{\mathrm{W}}) * \mathrm{~W}) * \overline{\mathrm{W}}) * \overline{\overline{\mathrm{W}}}) * \overline{\mathrm{W}}) * \mathrm{~W} \text {; } \\
& (((((((((((((((\mathrm{X} * \overline{\mathrm{X}}) * \overline{\overline{\mathrm{Y}}}) * \overline{\mathrm{Y}}) * \mathrm{Y}) * \overline{\mathrm{Y}}) * \overline{\overline{\mathrm{Z}}}) * \overline{\mathrm{Z}}) * \mathrm{Z}) * \overline{\mathrm{Z}}) * \overline{\overline{\mathrm{Z}}}) * \overline{\overline{\mathrm{W}}}) * \overline{\mathrm{W}}) * \mathrm{~W}) * \overline{\mathrm{W}}) * \overline{\overline{\mathrm{W}}} * \overline{\mathrm{W}}) * \mathrm{~W} \text {; } \\
& (((((((((((((((\mathrm{X} * \overline{\mathrm{X}}) * \overline{\overline{\mathrm{X}}}) * \overline{\overline{\mathrm{Y}}}) * \overline{\mathrm{Y}}) * \mathrm{Y}) * \overline{\mathrm{Y}}) * \overline{\overline{\mathrm{Z}}}) * \overline{\mathrm{Z}}) * \mathrm{Z}) * \overline{\mathrm{Z}}) * \overline{\overline{\mathrm{W}}}) * \overline{\mathrm{W}}) * \mathrm{~W}) * \overline{\mathrm{W}}) * \overline{\overline{\mathrm{W}}}) * \overline{\mathrm{W}}) * \mathrm{~W} \text {; } \\
& (((((((((((((((\mathrm{X} * \overline{\mathrm{X}}) * \overline{\overline{\mathrm{Y}}}) * \overline{\mathrm{Y}}) * \mathrm{Y}) * \overline{\mathrm{Y}}) * \overline{\overline{\mathrm{Z}}}) * \overline{\mathrm{Z}}) * \mathrm{Z}) * \overline{\mathrm{Z}}) * \overline{\overline{\mathrm{W}}}) * \overline{\mathrm{W}}) * \mathrm{~W}) * \overline{\mathrm{W}}) * \overline{\overline{\mathrm{W}}}) * \overline{\mathrm{W}}) * \mathrm{~W}) * \overline{\mathrm{W}} \text {; } \\
& (((((((((((()(((\mathrm{X} * \overline{\mathrm{X}}) * \overline{\overline{\mathrm{Y}}}) * \overline{\mathrm{Y}}) * \mathrm{Y}) * \overline{\mathrm{Y}}) * \overline{\overline{\mathrm{Y}}}) * \overline{\overline{\mathrm{Z}}}) * \overline{\mathrm{Z}}) * \mathrm{Z}) * \overline{\mathrm{Z}}) * \overline{\overline{\mathrm{W}}}) * \overline{\mathrm{W}}) * \mathrm{~W}) * \overline{\mathrm{W}}) * \overline{\overline{\mathrm{W}}}) * \overline{\mathrm{W}}) * \mathrm{~W}) * \overline{\mathrm{W}} \\
& ((((((((((((((((\mathrm{X} * \overline{\mathrm{X}}) * \overline{\overline{\mathrm{Y}}}) * \overline{\mathrm{Y}}) * \mathrm{Y}) * \overline{\mathrm{Y}}) * \overline{\overline{\mathrm{Z}}}) * \overline{\mathrm{Z}}) * \mathrm{Z}) * \overline{\mathrm{Z}}) * \overline{\overline{\mathrm{Z}}}) * \overline{\overline{\mathrm{W}}}) * \overline{\mathrm{W}}) * \mathrm{~W}) * \overline{\mathrm{W}}) * \overline{\overline{\mathrm{W}}}) * \overline{\mathrm{W}}) * \mathrm{~W}) * \overline{\mathrm{W}} \\
& ((((((((((((((((\mathrm{X} * \overline{\mathrm{X}}) * \overline{\overline{\mathrm{X}}}) * \overline{\overline{\mathrm{Y}}}) * \overline{\mathrm{Y}}) * \mathrm{Y}) * \overline{\mathrm{Y}}) * \overline{\overline{\mathrm{Z}}}) * \overline{\mathrm{Z}}) * \mathrm{Z}) * \overline{\mathrm{Z}}) * \overline{\overline{\mathrm{W}}}) * \overline{\mathrm{W}}) * \mathrm{~W}) * \overline{\mathrm{W}}) * \overline{\overline{\mathrm{W}}}) * \overline{\mathrm{W}}) * \mathrm{~W}) * \overline{\mathrm{W}}
\end{aligned}
$$

ТАПАЗ-2 - это инструмент для построения модели мира в форме, пригодной для обработки данных на естественном языке в системах искусственного интеллекта. Интеллектуальная база знаний компьютера включает семантический классификатор - финальный упорядоченный (векторный) набор семантических примитивов (акций и их участников) и семантическую онтологию - алгоритм порождения новых смысловых единиц из исходного набора примитивов, представленный в виде графа знаний ТАПАЗ.

Интеллектуальная (экспертная) поисковая система, основанная на семантическом классификаторе ТАПАЗ-2, состоит из интеллектуальной поисковой машины, которая находит, просматривает и выбирает интернет-контент по заданной теме, и диалогового пользовательского интерфейса, позволяющего в интерактивном режиме обрабатывать запросы пользователя и преобразовывать их в канонизированный вид, соответствующий машиночитаемой модели мира, причём пользователь во время обучения системы будет подтверждать, правильно ли было выполнено преобразование, и если нет, то предлагать свою расшифровку через семантический классификатор.

Интеллектуальная поисковая система может использоваться для решения различных экспертных задач, в том числе и автоматического определения семантически эквивалентных фрагментов текстовых документов, о чём речь пойдёт ниже. Её главными компонентами являются: модуль онлайн-мониторинга интернет-контента с адекватными веб-роботами краулером и степлером; модуль автоматического лексического анализа с тэггером на семантической (части языка), а не морфологической (части речи) основе ${ }^{3}$; модуль динамического синтаксического анализа (парсера) с алгоритмом рекурсивной реконструкции членов предложения по технологии комбина́торной семантики; модуль прямого и обратного преобразования синтаксических выражений в алгебраические формулы ТАПАЗ-2, а также интеллектуальная база знаний (ИБЗ), состоящая из ТАПАЗ-юнитов (ИБЗ-таксономии), собранных в порядке, указанном графом семантического классификатора (ИБЗ-онтологии). Во время автоматического лексического анализа таксономия базы знаний также используется в качестве семантического словаря соответствующей предметной области.

\footnotetext{
${ }^{3}$ О различии частей языка и частей речи см.: [Гордей, 2000, 2003, 2006, 2011 ; Карасева, 2014 ; Руденко, 2010].
} 


\section{Семантический классификатор ТАПАЗ}

\section{1. Таблица семантических примитивов (макропроцессов) или парадигма акций}

Таблицу составляют физические и информационные макропроцессы, упорядоченные ТАПАЗ-алгеброй, физические макропроцессы заштрихованы (рис. 2).

\begin{tabular}{|c|c|c|c|c|c|}
\hline & & $\mathrm{I}$ & II & III & IV \\
\hline \multirow{8}{*}{ A } & \multirow[t]{2}{*}{$a$} & 1 воспрннимание & запоминание & осмысливание & понимание \\
\hline & & притягивание 57 & скапливанне $\quad 58$ & ужимание $\quad 59$ & присоединение 60 \\
\hline & \multirow[t]{2}{*}{$b$} & 5 перенимание & 6 заучивание & 7 обдумывание & 8 усвапвание \\
\hline & & вбирание $\quad 61$ & накапливание $\quad 62$ & центрирование 63 & асспмилирование 64 \\
\hline & \multirow[t]{2}{*}{$c$} & \multirow{2}{*}{$\begin{array}{l}9 \text { прочувствование } \\
\text { перевбиранне } 65\end{array}$} & созерцание & 11 переживание & 12 изведывание \\
\hline & & & концентрирование 66 & центрифугирование 67 & дисспмшлирование 68 \\
\hline & \multirow[t]{2}{*}{$d$} & 13 отвергание & изглаживание & 15 переосмысливание & 16 изживание \\
\hline & & выделение $\quad 69$ & разуплотнение $\quad 70$ & отжимание $\quad 71$ & отъединение 72 \\
\hline \multirow{8}{*}{ B } & \multirow[t]{2}{*}{$a$} & 17 сообщение & 18 рекламирование & 19 внушение & 20 констатирование \\
\hline & & подведение 73 & наращивание 74 & прижимание 75 & подсоединение 76 \\
\hline & \multirow[t]{2}{*}{$b$} & 21 объяснение & 22 пропагандирование & 23 доказывание & 24 удостоверивание \\
\hline & & введение $\quad 77$ & нагнетание 78 & вжимание 79 & соединение $\quad 80$ \\
\hline & \multirow[t]{2}{*}{$c$} & 25 ниспослание & вещание & 27 просветление & 28 явление \\
\hline & & проведение 81 & распространение 82 & выжимание 83 & разъединение 84 \\
\hline & \multirow[t]{2}{*}{$d$} & 29 затемнение & 30 шифрование & 31 дискредитирование & 32 дезавуирование \\
\hline & & выведение 85 & осаживание $\quad 86$ & оттеснение $\quad 87$ & отсоединение 88 \\
\hline \multirow{8}{*}{$\mathrm{C}$} & \multirow[t]{2}{*}{$a$} & 33 информирование & 34 заинтересовывание & 35 уверение & 36 предрасположенше \\
\hline & & затрагивание 89 & обволакивание 90 & обжимание 91 & формование 92 \\
\hline & \multirow[t]{2}{*}{$b$} & 37 наставление & 38 обучение & 39 убежденпге & 40 воспитаниг \\
\hline & & вскрывание $\quad 93$ & наполнение 94 & сжимание 95 & формирование 96 \\
\hline & \multirow[t]{2}{*}{$c$} & 41 пронгмание & 42 пренсполнение & 43 преображение & 44 перевоплощенге \\
\hline & & пронизывание 97 & переполнение 98 & разжимание 99 & выхолашивание 100 \\
\hline & \multirow[t]{2}{*}{$d$} & 45 доншманше & 46 зомбирование & 47 умопомраченाе & 48 умалишение \\
\hline & & пробивание 101 & вздыманше $\quad 102$ & распускание $\quad 103$ & аннитилирование 104 \\
\hline \multirow{4}{*}{ D } & \multirow[t]{2}{*}{$a$} & 49 воспоминание & 50 воссоздание & 51 возобновление & 52 воспропзведение \\
\hline & & рехристаллизирование 105 & реинтегрирование 106 & регенерирование 107 & реформование 108 \\
\hline & \multirow[t]{2}{*}{$b$} & 53 репродуцитованпе & 54 рекультивирование & 55 возрожденше & 56 воскрешенте \\
\hline & & рекуперирование 109 & реабилитирование 110 & реактивирование 111 & реанімирование 112 \\
\hline
\end{tabular}

Puc. 2. Таблица семантических примитивов (макропроцессов)

или парадигма акций (рус.)

$A-$ группа активизации, $B$ - группа эксплуатации, $C$ - группа трансформации, $D-$ группа нормализации; $a$ - подгруппа среда-оболочк $a, b$ - подгруппа оболочка-ядро, $c$ - подгруппа ядро-оболочк $a, d$ - подгруппа оболочка-среда; $I$ - ряд инициации, $I I$ - ряд аккумуляции, $I I I$ - ряд амплификации, $I V$ - ряд генерации.

\section{2. Векторный лист ролей индивидов}

Упорядоченный ТАПАЗ-алгеброй векторный лист ролей индивидов (ролевой лист ТАПАЗ) представляет собой следующий набор ${ }^{4}$ :

субъекта (инициатора $\rightarrow$ вдохновителя $\rightarrow$ распространителя $\rightarrow$ вериителя) $\rightarrow$ инструмента (активатора $\rightarrow$ суппрессора $\rightarrow$ усилителя $\rightarrow$ преобразователя) $\rightarrow$ медиатора (ориентира $\rightarrow$ локуса $\rightarrow$ транспортёра $\rightarrow$ адаптера $\rightarrow$ акцептора $\rightarrow$ запаса $\rightarrow$ сепаратора $\rightarrow$ материала $\rightarrow$ макета $\rightarrow$ фиксатора $\rightarrow$ ресурса $\rightarrow$ стимула $\rightarrow$ регулятора $\rightarrow$ хронотопа $\rightarrow$ источника $\rightarrow$ индикатора) $\rightarrow$ объекта (покрытия $\rightarrow$ корпуса $\rightarrow$ прослойки $\rightarrow$ сердиевины $) \rightarrow$ продукта (заготовки $\rightarrow$ полуфабриката $\rightarrow$ прототипа $\rightarrow$ изделия).

${ }^{4}$ Посильную помощь в интерпретации некоторых формул ролевого листа ТАПАЗ оказала М. И. Святощик [Святощик, 2020]. 


\section{3. Граф знаний ТАПАЗ}

Граф описывает отношения между активным и уточняющим макропроцессами (см. рис. 1). Максимальная степень вершины в графе знаний равна количеству вершин в изначальном множестве (все вершины изначального множества участвуют в порождении вершины степени $n$ ). Таким образом, чтобы получить количество вершин в графе, необходимо просуммировать количество вершин всех степеней от 1 до $n$ :

$$
\mathrm{S}_{n}=\sum_{k=1}^{n} A_{n}^{k} \times C_{k}=\sum_{k=1}^{n} \frac{n !}{(n-k) !} \times \frac{(2(k-1)) !}{(k-1) k !} .
$$

Код программы на языке Python, вычисляющий функцию $S(n)$ по формуле (1):

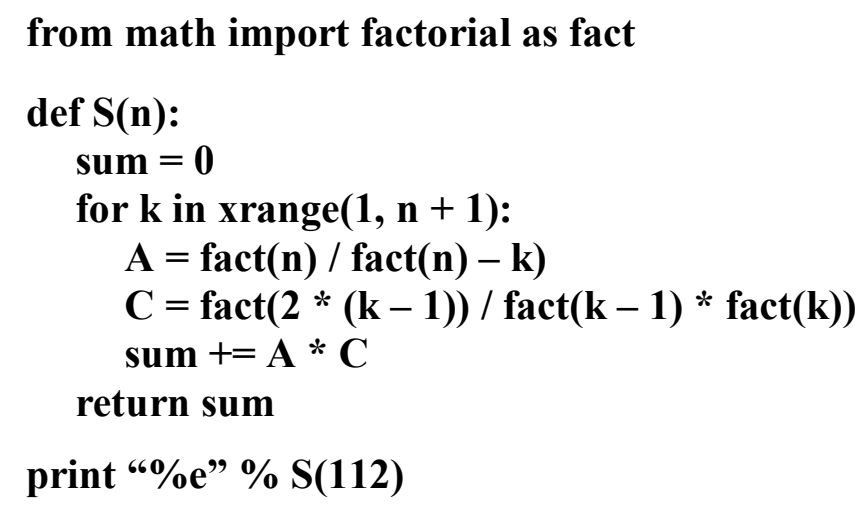

Таблица семантических примитивов ТАПАЗ (см. рис. 2) в основании графа знаний содержит 112 элементов. Подставив это число в формулу (1) в качестве $n$, получаем:

$$
S_{n} \approx 8,2 \times 10^{245}
$$

В настоящее время не существует вычислительных мощностей, способных обработать и сохранить подобный объём информации. Следовательно, необходимо адаптировать граф знаний ТАПАЗ к возможностям современной вычислительной техники, выделив в нём наиболее значимую часть. Сокращение количества вершин достигается тремя способами:

- вводом ограничений на способ порождения вершин;

- разделением полного графа на два отдельных подграфа;

- ограничением глубины детализации (спецификации) процессов.

Сочетание трёх способов позволяет регулировать количество обрабатываемых вершин. Например, можно найти степень $k$, при которой глубина детализации процессов достаточна для достижения требуемой семантической мощности, но при этом количество вершин в графе остаётся в пределах, доступных для обработки и хранения с помощью современных вычислительных средств.

Рассмотрим количество вершин в полном графе знаний ТАПАЗ и в графе, построенном методом последовательной детализации (табл. 1). Уже на уровне детализации $k_{\max }=3$ количество порождённых вершин, умноженное на количество ролей индивидов $k=31$, превышает 85 млн, притом что Словарь современного русского литературного языка в 17 томах содержит 120480 слов, заявленный объём Большого академического словаря русского языка 150000 слов, а имеющиеся электронные ресурсы Института лингвистических исследований РАН на 1,4 млрд словоупотреблений содержат около 5 млн русскоязычных слов XVIII-XXI веков [Кругликова, 2012]. 
Сокращение размерности графа знаний за счёт ограничения глубины детализации процессов

\begin{tabular}{|c|c|c|c|c|}
\hline $\begin{array}{c}\text { Глубина } \\
\begin{array}{c}\text { детализации } \\
\boldsymbol{k}_{\max }\end{array}\end{array}$ & \multicolumn{2}{|c|}{ Полный граф } & \multicolumn{2}{|c|}{ Граф стандартного вида } \\
\hline 2 & $S_{n}$ & $S_{n} \times 31$ & $S_{n}$ & $S_{n} \times 31$ \\
\hline 2 & 12544 & 388864 & 12544 & 388864 \\
\hline 3 & 2747584 & 85175104 & 2747584 & 85175104 \\
\hline 4 & 748045984 & 23189425504 & 598986304 & 18568575424 \\
\hline
\end{tabular}

На уровне же детализации $k_{\max }=4$ количество вершин полного графа знаний ТАПАЗ, умноженное на количество ролей индивидов, превышает 23 млрд. Поскольку раздельная генерация графов физических и информационных макропроцессов значительно сокращает количество полученных величин, такой способ исчисления позволяет увеличить возможную глубину детализации. Результаты представлены в таблице 2, аналогичной таблице 1, только для графа, построенного на множестве из 56 вершин первой степени.

Таблица 2

Размерность графов физических и информационных процессов с ограниченной глубиной детализации

\begin{tabular}{|c|c|c|c|c|}
\hline $\begin{array}{c}\text { Глубина } \\
\text { детализации } \\
\boldsymbol{k}_{\max }\end{array}$ & \multicolumn{2}{|c|}{ Полный граф } & \multicolumn{2}{|c|}{ Граф стандартного вида } \\
\cline { 1 - 5 } & $S_{n}$ & $S_{n} \times 31$ & $S_{n}$ & $S_{n} \times 31$ \\
\hline 2 & 3136 & 97216 & 3136 & 97216 \\
\hline 3 & 335776 & 10409056 & 335776 & 10409056 \\
\hline 4 & 44410576 & 1376727856 & 35595616 & 1103464096 \\
\hline 5 & 6461701456 & 200312745136 & 3702618976 & 114781188256 \\
\hline
\end{tabular}

На глубине детализации $k_{\max }=4$ количество вершин в полном графе знаний ТАПАЗ, умноженное на количество ролей индивидов, не превышает 2 млрд. Таким образом, мы получаем дополнительный уровень детализации для увеличения точности исчисления предметных областей 5 .

\section{4. Семантический словарь ТАПАЗ}

Должно быть одно-однозначное соответствие не только между именными группами и тематическими ролями, как отмечал Н. Хомский [Chomsky, 1981], но и одно-однозначное соответствие между ролями индивидов в событии, членами предложения, описывающего это событие ${ }^{6}$, и частями языка - субстантивами и предикативами ${ }^{7}$, в роли членов данного

\footnotetext{
${ }^{5}$ Более подробно о графе знаний ТАПАЗ см.: [Hardzei, Udovichenko, 2019].

${ }^{6}$ Синтаксические правила для модуля динамического синтаксического анализа (парсера) с алгоритмом рекурсивной реконструкции структуры предложения см.: [Гордей, 2007, 2017]. 2003, 2006].

Определения частей языка, их парадигму и процедуры семантического разграничения см.: [Гордей,
} 
предложения, иначе мы не сможем использовать алгоритмы машинного обучения, такие как, например, искусственная нейронная сеть или случайный лес, и тем самым обеспечить автоматическую семантическую разметку текстов, собранных в базе знаний.

Семантический словарь ТАПАЗ состоит из предметно ориентированных ТАПАЗюнитов (семантически структурированных словарей предметных областей), собранных в порядке, указанном графом знаний ТАПАЗ. Шаблоны юнитов (векторные листы ролей индивидов) формируют таксономию интеллектуальной базы знаний, а граф знаний — её онтологию. На начальном этапе ТАПАЗ-юниты собираются экспертами вручную по заданным правилам до тех пор, пока данных будет достаточно для подключения алгоритмов машинного обучения.

В настоящее время технология ТАПАЗ частично используется для лингвистического обеспечения подсистемы интернет-мониторинга мероприятия $5^{1}$ «Разработка интеллектуальной веб-системы поиска и обработки текстов на английском и русском языках методом семантического кодирования для информационной поддержки решения управленческих, проектно-поисковых и экспертных задач в области дистанционного зондирования Земли» раздела 1 «Развитие Белорусской космической системы дистанционного зондирования Земли» подпрограммы 7 «Исследование и использование космического пространства в мирных целях» государственной программы «Наукоёмкие технологии и техника» на 2016-2020 годы. Алгоритм извлечения экспертом специализированной терминологии из тематических текстов в области дистанционного зондирования Земли для наполнения интеллектуальной базы знаний ТАПАЗ предполагает использование программного инструмента ExpertTool.exe версии 2.3.4.7, разработанного А. А. Мацко (рис. 3, 4).

Мы прилагаем значительные усилия для адаптации технологии ТАПАЗ к работе в английском и китайском секторах IT-индустрии. В частности, при технической поддержке Л. Боултона-Смита (Великобритания) был подготовлен семантический классификатор физических и информационных макропроцессов на английском языке (рис. 5), а с участием Жэнь Сюэ (КНР) - семантический классификатор физических макропроцессов ряда инициации на китайском языке (рис. 6).

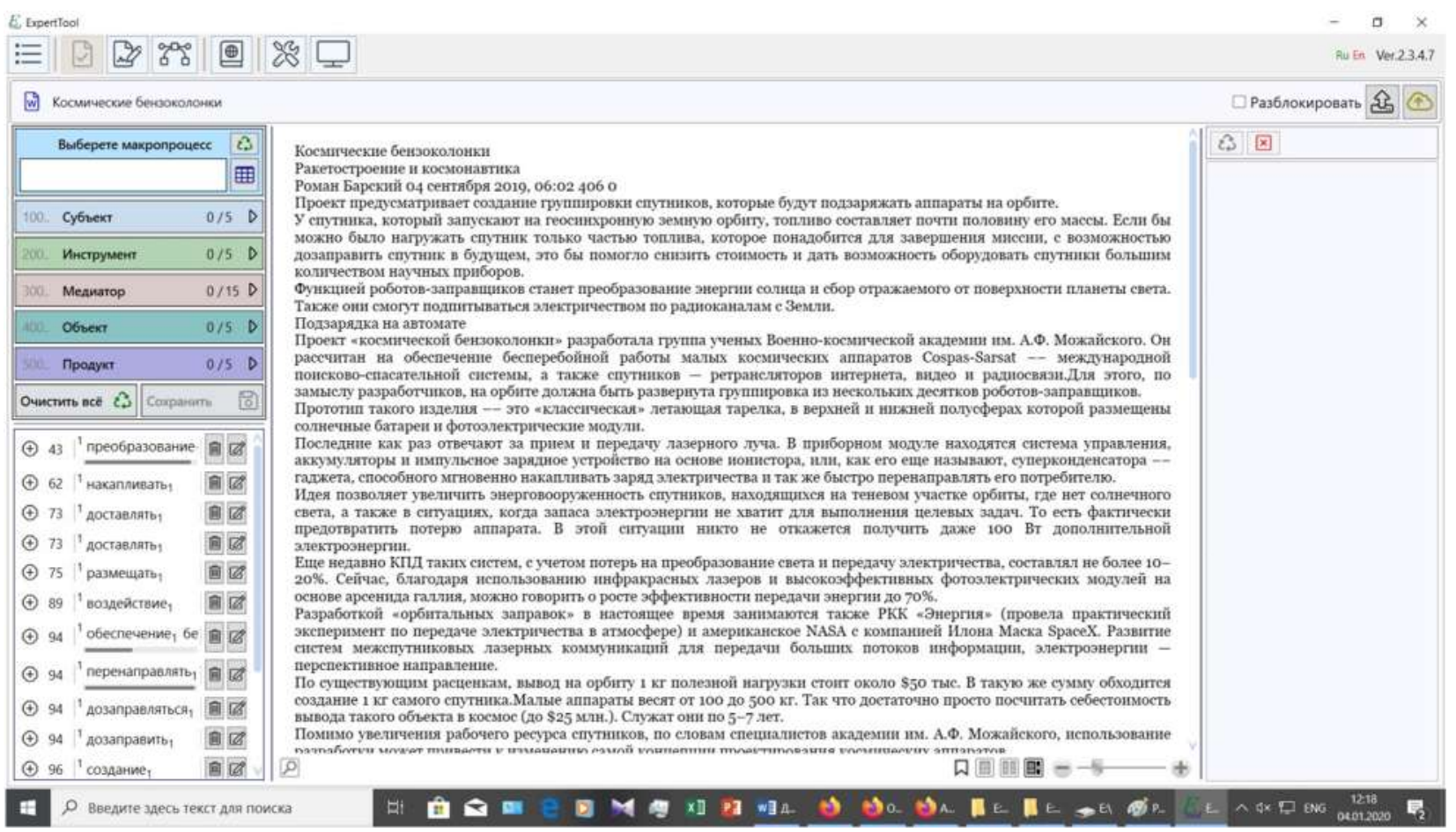

Рис. 3. Рабочее окно программного инструмента 


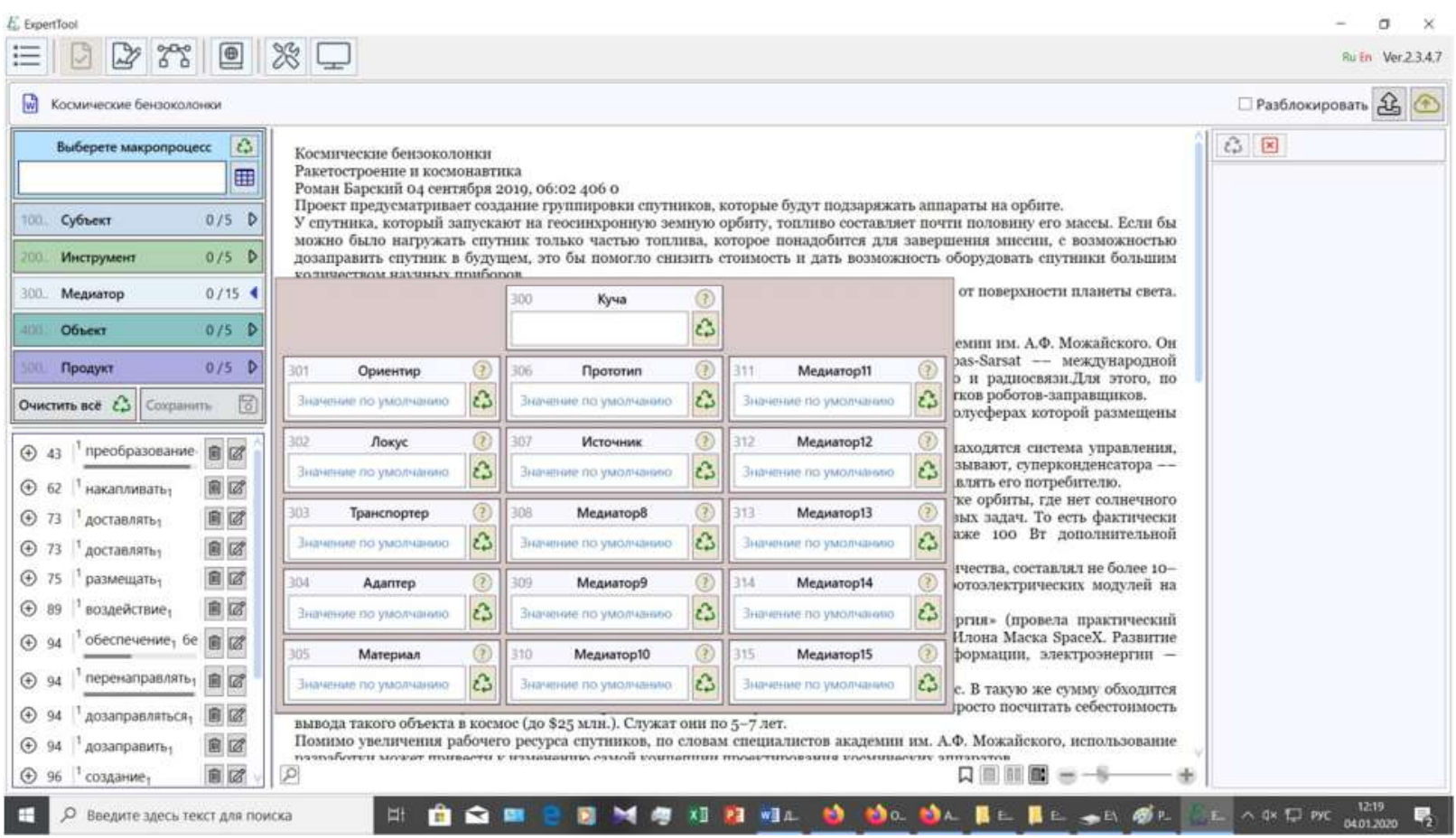

Рuc. 4. Рабочее окно программного инструмента с развёрнутой вкладкой

\begin{tabular}{|c|c|c|c|c|c|}
\hline & & I & II & III & IV \\
\hline \multirow{8}{*}{ A } & \multirow{2}{*}{$a$} & perceive & reflect & comprehend & understand \\
\hline & & attract & cumulate & constrict $\quad 59$ & attain \\
\hline & \multirow{2}{*}{$b$} & adopt & $6 \quad$ memorize & $7 \quad$ contemplate & learn \\
\hline & & absorb & accumulate $\quad 62$ & center & assimilate \\
\hline & \multirow[b]{2}{*}{$c$} & feel & behold & 11 feel profoundly & 12 experience \\
\hline & & over absorb & concentrate & centrifuge $\quad 67$ & dissimilate $\quad 68$ \\
\hline & \multirow{2}{*}{$d$} & reject & erase & rethink & 16 overcome \\
\hline & & expel & decompress & force off & disassociate $\quad 72$ \\
\hline \multirow{8}{*}{ B } & \multirow{2}{*}{$a$} & notify & advertise & instill & state \\
\hline & & approach & joint & press down & connect \\
\hline & \multirow{2}{*}{$b$} & explain & propagandize & prove & certify \\
\hline & & insert & pump & press in & link \\
\hline & \multirow[b]{2}{*}{$c$} & reveal & prophesize & 27 enlighten & divine \\
\hline & & conduct & spread & squeeze out 83 & disconnect \\
\hline & \multirow{2}{*}{$d$} & darken & encode & $31 \quad$ discredit & disavow \\
\hline & & take out & pull up & push out & unlink \\
\hline \multirow{8}{*}{$\mathrm{C}$} & \multirow{2}{*}{$a$} & inform & interest & assure & predispose \\
\hline & & touch on & envelope & squeeze & mold \\
\hline & \multirow{2}{*}{$b$} & admonish & teach & convince & nurture \\
\hline & & rip up & fill up & press & form \\
\hline & \multirow{2}{*}{$c$} & pierce & intend & transfigure & $44 \quad$ reincarnate \\
\hline & & penetrate & overflow & unclamp $\quad 99$ & $\begin{array}{ll}\text { eviscerate } & 100\end{array}$ \\
\hline & \multirow{2}{*}{$d$} & pester & $46 \quad$ mesmerize & 47 lose conscious & go mad \\
\hline & & punch & uplift & disband & annihilate \\
\hline \multirow{4}{*}{$\mathrm{D}$} & \multirow{2}{*}{$a$} & $49 \quad$ recollect & recreate & restart & render \\
\hline & & recrystallize $\quad 105$ & reintegrate & regenerate & restore \\
\hline & \multirow{2}{*}{$b$} & $53 \quad$ reproduce & reclaim & renew & revive \\
\hline & & recuperate $\quad 109$ & rehabilitate & reactivate & reanimate \\
\hline
\end{tabular}

Рuc. 5. Таблица семантических примитивов (макропроцессов) или парадигма акций (англ.) 


\begin{tabular}{|c|c|c|c|c|c|}
\hline & & I & & $\begin{array}{c}\text { Современный китайско-русский } \\
\text { словарь двойного толкования }\end{array}$ & $\begin{array}{c}\text { Расширенное } \\
\text { собрание синонимов }\end{array}$ \\
\hline \multirow{4}{*}{ A } & $a$ & притягивание & 57 & 拉近, 拖近, 移来 & 靠近 \\
\hline & $b$ & вбирание & 61 & 吸收, 吸取, 吸入 & 收 \\
\hline & $c$ & перевбирание & 65 & 逐个查看、挑选、翻阅, 逐一思考 & 挨次: 选拔 \\
\hline & $d$ & выделение & 69 & 挑出, 选出; 分出, 拨出; 指派 & 挑选 \\
\hline \multirow{4}{*}{ B } & $a$ & подведение & 73 & 引近, 引到跟前, 带到; 修到, 安装到 & 带路 \\
\hline & $b$ & введение & 77 & 引|入, 领入, 带入; 㚎进, 签入 & 进, 进来 \\
\hline & $c$ & проведение & 81 & 引过, 领着通过 & 通过 \\
\hline & $d$ & выведение & 85 & 领出, 带出, 引出; 签出; 领到 & 引来 \\
\hline \multirow{4}{*}{$\mathrm{C}$} & $a$ & затрагивание & 89 & 碰到, 触及 & 相遇 \\
\hline & $b$ & вскрывание & 93 & 打开, 拆开, 启开 & 开 \\
\hline & $c$ & пронизывание & 97 & 穿透, 刺入, 贯穿 & 穿透 \\
\hline & $d$ & пробивание & 101 & 打, 㪣 & 㪣打 \\
\hline \multirow{2}{*}{$\mathrm{D}$} & $a$ & рекристаллизирование & 105 & 再结晶 & 一 \\
\hline & $b$ & рекуперирование & 109 & 再生,复原, 回热利废,余热利用 & 再生 \\
\hline
\end{tabular}

Puc. 6. Таблица семантических примитивов (физических макропроцессов) или парадигма физических акций ряда инициации (кит.)

Алгоритм извлечения экспертом специализированной терминологии из тематических текстов и заполнения предметных полей ТАПАЗ (шаблона ТАПАЗ-юнитов в области дистанционного зондирования Земли) аналогичен обновлённому векторному листу ролей индивидов:

субъекта (инициатора $\rightarrow$ вдохновителя $\rightarrow$ распространителя $\rightarrow$ вершителя) $\rightarrow$ инструмента (активатора $\rightarrow$ суппрессора $\rightarrow$ усилителя $\rightarrow$ преобразователя) $\rightarrow$ медиатора (ориентира $\rightarrow$ локуса $\rightarrow$ транспортёра $\rightarrow$ адаптера $\rightarrow$ акцептора $\rightarrow$ запаса $\rightarrow$ сепаратора $\rightarrow$ материала $\rightarrow$ макета $\rightarrow$ фиксатора $\rightarrow$ ресурса $\rightarrow$ стимула $\rightarrow$ регулятора $\rightarrow$ хронотопа $\rightarrow$ источника $\rightarrow$ индикатора) $\rightarrow$ объекта (покрытия $\rightarrow$ корпуса $\rightarrow$ прослойки $\rightarrow$ сердиевины) $\rightarrow$ продукта (заготовки $\rightarrow$ полуфабриката $\rightarrow$ прототипа $\rightarrow$ изделия),

где субъект - инициатор акции, объект - реципиент акции, продукт - результат воздействия субъекта на объект (индивид, адаптированный к заданной роли в новой акции), инструмент - исполнитель акции (ближайший к субъекту индивид), медиатор - посредник акции (ближайший к объекту индивид).

Разновидности субъекта: инициатор - инициирует акцию, распространитель распространяет акцию, вдохновитель - вовлекает в акцию, вершитель - завершает акцию производством из объекта продукта. Разновидности инструмента: активатор - непосредственно воздействует на медиатор, суппрессор - подавляет сопротивление медиатора, усилитель - наращивает воздействие на медиатор, преобразователь - преобразует медиа- 
тор. Разновидности медиатора: ориентир - ориентирует воздействие на объект, локус локализует объект в пространстве, транспортёр - перемещает объект, адаптер - приспосабливает инструмент к воздействию на объект, материал - используется в качестве объекта-сырья для производства продукта, макет - является исходным образцом для производства из объекта продукта, фиксатор - превращает переменный локус объекта в постоянный, ресурс - питает инструмент, стимул - проявляет параметр объекта, регулятор - служит инструкцией в производстве из объекта продукта, хронотоп - локализует объект во времени, источник - обеспечивает инструкциями инструмент, индикатор - отображает параметр воздействия на объект или параметр продукта как результата воздействия на объект. Разновидности объекта: покрытие - внешняя изоляция оболочки индивида, корпус - оболочка индивида, прослойка - внутренняя изоляция оболочки индивида, сердчевина - ядро индивида. Разновидности продукта: заготовка - превращённый в сырьё объект, полуфабрикат - наполовину изготовленный из сырья продукт, прототип - опытный образец продукта, изделие - готовый продукт.

Интерактивное заполнение векторного листа ролей индивидов каждого специфицированного процесса предметной области дистанционного зондирования Земли предполагает ответы на типовые вопросы: Кто? При помощи чего? В отношении кого/чего? Находясь где? Прибыв на чём? Приспосабливая чем? Улавливая чем? Запасиись чем? Сортируя чем? Изготавливая из чего? На примере чего? Фиксируя чем? Расходуя что? Стимулируя чем? Руководствуясь чем? В периоде каком? Зная откуда? При параметре каком? Воздействуя на кого/что? Производит кого/что?

Семантический словарь ТАПАЗ играет ключевую роль в выявлении семантической эквивалентности текстовых документов и заимствовании научных идей:

- если в результате автоматической семантической разметки двух текстов, относящихся к одной предметной области, обнаруживается факт совпадения одного, двух или трёх ТАПАЗ-юнитов, то семантическая эквивалентность этих текстов оценивается соответственно как слабая, средняя и сильная;

- если в результате автоматической семантической разметки двух текстов, относящихся к разным предметным областям, обнаруживается факт совпадения одного, двух или трёх ТАПАЗ-юнитов, то заимствование идеи оценивается соответственно как слабое, среднее и сильное.

Заимствование идеи не всегда следует квалифицировать как плагиат, поскольку её адаптация к другой предметной области часто требует значительных интеллектуальных усилий. Решение задач по аналогии является стандартной процедурой в Теории решения изобретательских задач (ТРИЗ) [Альтшуллер, 2007]. Универсальный решатель задач ТАПАЗ также позволяет решать некоторые задачи по аналогии, в том числе и такую повседневную, как очистить яйцо от скорлупы, которая, как оказалось, имеет три решения:

1) в подгруппе среда-оболочка - раздробить;

2) подгруппе оболочка-ядро - ввести расщепляющий реагент;

3) подгруппе ядро-оболочка - разжать изнутри расширением объёма ядра.

Последний способ чаще всего используют птицы, когда высиживают птенцов. Любопытно, что в Интернете можно найти только множество описаний дробления скорлупы различными инструментами, остальные два решения являются уникальными, никогда в практической деятельности человеком не применялись и, разумеется, никакие инструменты для этого не изготавливались.

На первый взгляд, речь идёт всего лишь об одной из многих обычных повседневных задач, но все семантически изоморфные изобретательские задачи, которые отнюдь не являются заурядными или тривиальными, решаются аналогичным образом, например: «Как убрать снег с лопастей снегоуборочной машины?» или «Как очистить ото льда корпус подводной лодки или самолёта?» и т. д. [Hardzei, 2017, p. 39]. 


\section{Примеры семантической разметки текстов в технологии ТАПАЗ}

Сообщение СМИ: Вчера в 10 ч 30 мин с космодрома Байконур осуществлён запуск Белорусского космического аппарата.

Предобработка текста экспертом посредством программного инструмента ТАПАЗ: Специалисть ФГУ «Роскосмос» 22.07.2012 в 10:30 с космодрома Байконур при помощи ракеть-носителя «Союз» на околоземную орбиту доставили Белорусский космический аппаpam; специфицированный процесс ДЗ3 - доставлять, макропроцесс ТАПАЗ - (73) подведение, субъект - ФГУ «Роскосмос», инструмент — ракета-носитель «Союз», объект Белорусский космический аппарат, локус - космодром Байконур, ориентир - околоземная орбита, хронотоп - 22.07.2012 10:30.

Техническое описание: Белорусский космический аппарат похож на российский.

Устойчивое сочетание белорусский космический аппарат играет роль подлежащего, но при этом не отображается в субъект, потому что белорусский космический аппарат с российским космическим аппаратом ничего не делает. Правильная семантическая реконструкция ролевой структуры предложения: «Некто что делает с информачией о белорусском космическом аппарате? Сравнивает её с информачией о российском космическом аппарате и констатирует тождество»; макропроцесс ТАПАЗ - (20) констатирование, субъект - виртуальный некто, объект - информачия о белорусском космическом аппарате, ориентир информаџия о российском космическом аппарате, продукт - совпадение информации.

Показательно решение с помощью технологии ТАПАЗ проблемы атрибутивного 的·de во время синтаксического анализа китайского предложения 皮球是红的。Píqiú shi hóng·de (Мяч красный). Дело в том, что китайский знак 红 hóng (красный) в языковой системе обозначает свойство, а в предложении играет специализированную роль определения, поэтому не требует навешивания 的 $d e$, переводящего индивидную семантику в атрибутивную, например: 石头 shitou (камень) $\rightarrow$ 石头的 shitou·de (каменный). Наличие 的·de в предложении-определении 皮球是红的 указывает на пропуск прямого дополнения 东西 dōngxi (вещь), (предмет), то есть мяч есть предмет красного цвета, а не сам красный цвет. Действительно, с точки зрения классической логики тождество должно устанавливаться между однородными объектами: индивидом и другим индивидом или признаком индивида и другим признаком индивида. В данном случае китайский язык оказывается более точным в представлении модели мира, чем русский. Правильный синтаксический разбор предложения: 皮球 píqiú (мяч) - подлежащее, 是 shi (ecmb) - сказуемое, 红的 hóng·de (красный) - определение, 东西 dōngxi (вещь), (предмет) - реконструированное прямое дополнение. Однако ролевая структура события будет иной: «Некто что делает с информаџией о ивете яблока? Сравнивает её с информаџией о красном ивете и констатирует ux тождество»; макропроцесс ТАПАЗ - (20) констатирование, субъект - виртуальный некто, объект - информаџия о ивете яблока, ориентир - информаџия о красном иявете, продукт - совпадение информации.

В силу того что в ядре языковой системы лежат семантические примитивы, следуеm добиваться минимальной глубины рекурсивной реконструкции, соблюдая строгие требования очередности, наглядности и простоты, когда пропущенные члены предложения восстанавливаются на первом или, максимум, на втором вхождении, потому что чем глубже рекурсия и сложнее реконструкция, тем большая вероятность ошибки.

Другой пример: 苹果多少钱两斤? Píngguǒ duōshao qián liăng jīn? Сколько cmoum

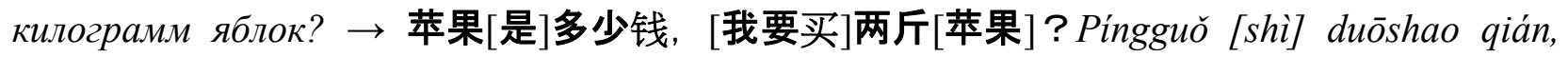
[wǒ yào măi] liăng jīn [píngguǒ]? Букв.: Яблоки [есть] сколько денег, [мне нужно купить] один килограмм [яблок]. 苹果 Píngguо̌ «яблоки» - подлежащее ${ }_{1}$, 是 shì «есть»- рекон- 
струированное сказуемое ${ }_{1}$, 钱 qián «деньгu»— прямое дополнение ${ }_{1}$, 多少 duōshao «сколь-

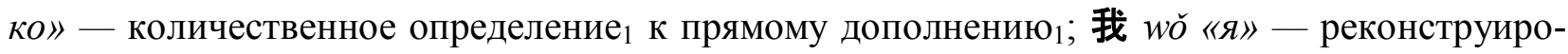
ванное подлежащее 2 , 要 yào «нужно» - реконструированный модальный компонент сказуемого $_{2}$, 买 măi «купить» - реконструированный основной компонент сказуемого ${ }_{2}$, 两斤 liăng jīn «один килограмм» - количественное определение 2 к реконструированному прямому дополнению 2 苹果 píngguо̌ «яблоки».

Для определения ролевой структуры события необходимо преобразование вопросительного предложения в повествовательное: «Покупатель запрашивает информацию о стоимости килограмма яблок, чтобы сопоставить её с информащией об имеющемся у него количестве денег; если информации совпадут, то покупатель купит яблоки»; макропроцесс ТАПАЗ - (1) воспринимание, объект - информация о стоимости килограмма яблок, источник - продавеи; макропроцесс 2 ТАПАЗ - (24) удостоверивание, объект - информациия о стоимости килограмла яблок, ориентир - количество денег у покупателя; макропроцесс 3 ТАПАЗ - (60) присоединение, субъект - покупатель, объект - килограмм яблок.

Отметим, что мощность семантической разметки, только в части типовых ролей индивидов, не говоря уже о ТАПАЗ-алгебре и порождаемых ею парадигмы акций и графа знаний, почти в 5 раз превосходит мощность своего ближайшего зарубежного аналога - технологию Активного словаря (Active Vocabulary) ${ }^{8}$, стандартизированную и одобренную в 2017 году Консорциумом W3C в рамках проекта Семантической паутины (Semantic Web) ${ }^{9}$ и затем проекта Схема.орг (Schema.org) ${ }^{10}$. Инвентарь этой технологии, преимущественно опирающейся на теорию семантических падежей Ч. Филлмора [Филлмор, 1981a, 1981б, 1988] и ранние работы Р. Джекендоффа [Jackendoff, 1972, 1977], о чём мы упоминали, составляют:

«Агенс - инициатор некоторого действия по своей воле и деятель - супертип агенса, который создаёт или контролирует ситуацию, обозначенную предикатом; пащиенс - сущность, подвергающаяся какому-либо воздействию, часто претерпевающая какое-то изменение; тема - сущность, вовлечённая в процесс, или чьё местонахождение описано; бенефициар - сущность, в пользу которой совершается действие; экспериенцер - сущность, которая осведомлена о действии или состоянии, описанном предикатом, но которая не контролирует действие или состояние;

объект восприятия или стимул - сущность, которая воспринимается или переживается;

инструмент - сущность, с помощью которой совершается действие или происходят какие-либо изменения;

источник - сущность, от которой что-либо движется в прямом или переносном смысле; цель - сущность, к которой что-либо движется в прямом или переносном смысле, и реципиент - подтип цели, участвующий в действиях, описывающих изменения владения; локация - место, в котором что-то находится или происходит» [Aarts, 2001, pp. 94-95].

Нетрудно заметить, что экспериенщер, источник, объект восприятия (стимул), цель и реципиент, по сути дела, представляют одну и ту же типовую роль ориентира в ТАПАЗ-2; пациенс и тема - роль объекта; агенс и деятель - роль субъекта и вериителя; бенефициар - роль медиатора; локация - роль локуса; роль инструмента в обеих теориях почти одинаковая, если не принимать во внимание разновидности инструмента в ТАПАЗ-2. Однако в обосновании семантических падежей Ч. Филлмора или «тэта-матриц» Т. Стоуэлла никакой алгебры нет, все эти семантические категории были выделены эмпирически, поэтому невозможно установить их непротиворечивость, независимость и полноту, тем

${ }^{8}$ CM.: Activity Vocabulary. W3C Recommendation. URL : https://www.w3.org/TR/activitystreams-vocabulary/\# dfn-activity (дата обращения: 18.04.2021).

${ }_{9}^{9}$ CM.: Semantic Web. URL : https://www.w3.org/standards/semanticweb. (дата обращения: 18.04.2021).

${ }^{10}$ См.: Schema.org Vocabulary, version 8.0. URL : https://schema.org. (дата обращения: 18.04.2021). 
самым избежать парадокса Рассела, который неизбежно возникает при смешении теории и метатеории, языка и метаязыка, семантики и метасемантики. Именно из-за этого разработчикам Семантической паутины, несмотря на титанические усилия по стандартизации технологии, до сих пор не удалось свести разнообразные предметные онтологии к онтологии верхнего уровня, которая, как подчёркивают многие комментаторы, является «критической для всей концепции» [Риппа, Ляшенко, 2013, с. 94].

\section{Заключение}

Таким образом, ядро системы (модель мира) на основе ТАПАЗ представляет собой сопряжение 112 макропроцессов (акций) семантического классификатора ТАПАЗ со специализированными процессами избранной предметной области, например, дистанционного зондирования Земли (ДЗ3). Каждый процесс имеет 32 семантических поля в соответствии с векторным листом ролей индивидов (обновлённым ролевым листом ТАПАЗ). Семантический вес специализированного процесса ДЗ3 в синонимическом ряду определяется полнотой полей, частотным индексом и высотой графа знаний ТАПАЗ по мере заполнения его вершин. Построение ядра системы осуществляется в ручном, полуавтоматическом и автоматическом режимах. На первом этапе допускается формирование интеллектуальной базы знаний путём интерактивного прописывания онтологических связей между независимой таксономией индивидов Д3З и зависимой таксономией процессов ДЗ3. Когда размер тренировочной области (количество содержащихся в ней данных) будет достаточным для подключения алгоритмов машинного обучения, таких как, например, искусственная нейронная сеть или случайный лес, дальнейшее пополнение интеллектуальной базы знаний будет выполняться в автоматическом режиме. Отметим отдельно, что построение Универсального решателя задач ТАПАЗ осуществляется при помощи ТАПАЗ-алгебры и семантического классификатора ТАПАЗ, то есть комбина́торными методами ${ }^{11}$, а не статистическими, поскольку все статистические методы, включая искусственные нейронные сети, лишь имитируют интеллектуальную или изобретательскую деятельность человека, с большей или меньшей достоверностью угадывая правильные решения, но в том, что нейронные сети способны эффективно масштабировать найденные комбина́торными методами решения, сомнений у нас нет. Более того, именно с появлением в 2007 году алгоритмов глубокого обучения многослойных нейронных сетей, предложенных Джеффри Хинтоном [Hinton, 2007 ; Hinton, Salakhutdinov, 2006], появилась возможность решать столь масштабные задачи, как составление обширных коллекций текстов различных предметных областей и оперирования большими данными силами одной научной лаборатории, тогда как раньше для этого требовались транснациональные научные конгломерации и глобальные межгосударственные объединения. В части масштабирования наших результатов исследования, определения релевантности тренировочной области и подбора адаптивных алгоритмов машинного обучения очень рассчитываем на всестороннее сотрудничество с ведущим белорусским специалистом в области искусственных нейронных сетей профессором В. А. Головко, a также с профессором В. В. Голенковым в рамках Открытых семантических технологий проектирования интеллектуальных систем (OSTIS Technology) [Golenkov, Gulyakina, Grakova, Davydenko, Nikulenka, Eremeev, Tarasov, 2018], которая ориентирована на разработку гибридных интеллектуальных систем. Уже есть хорошие примеры базы знаний OSTIS, описывающие лексические, синтаксические и семантические категории в терминах ТАПАЗ

${ }^{11}$ Комбина́торная семантика занимается изучением отображения языком динамики ролей индивидов в событии. Её основоположником мы считаем 3. Харриса, выдвинувшего ядерную семантическую цепочку субъект - акция - объект в качестве отправного пункта формализации предложения [Нarris, 1962]. Исследования в этом направлении были продолжены Минской семантической школой под руководством В. В. Мартынова и А. Н. Гордея. Комбина́торную семантику не следует смешивать с комбинато́рной, изучающей совместную встречаемость знаков при помощи статистических методов, основателем которой также является 3. Харрис [Хэррис, 1962]. 
и доступные для реализации в алгоритмах обработки и понимания естественного языка [Hardzei, Krapivin, 2020]. Технология OSTIS с её оригинальным объектно-ориентированным языком программирования высокого уровня является, на наш взгляд, наиболее подходящей для погружения алгоритмов ТАПАЗ в программную среду.

Специализированная интеллектуальная база знаний (СИБЗ) актуальных космических исследований и технологий в области ДЗЗ объединяет ядро системы на основе ТАПАЗ с периферией, порождаемой графом знаний ТАПАЗ и расширяемой ступенчатой рекурсией [Hardzei, 2017] и обновлённым ролевым листом ТАПАЗ.

Правила построения, ограничения, сокращения и преобразования алгебраических выражений, правила их чтения и интерпретации типовых совмещений индивидов, правила построения графа знаний ТАПАЗ и процедуры семантического кодирования и декодирования его вершин, обновлённый ролевой лист ТАПАЗ, группы и ряды парадигмы акций ТАПАЗ и ступенчатая рекурсия универсального решателя задач ТАПАЗ напрямую взаимодействуют с диалоговым веб-интерфейсом, который, как мы отмечали ранее, позволяет в интерактивном режиме обрабатывать запросы пользователя и преобразовывать их в канонизированный вид, соответствующий машиночитаемой модели мира, причём пользователь во время обучения системы будет подтверждать, правильно ли было выполнено преобразование, и если нет, то предлагать свою расшифровку через семантический классификатор. Таким образом, идея основателя и главы консорциума W3C Т. Бернерса-Ли о том, что «полученная в результате инфраструктура будет стимулировать разработку автоматизированных вебсервисов как высокофункциональных агентов...», а «...обычные пользователи станут составлять страницы семантической паутины и добавлять новые определения и правила, используя готовое программное обеспечение, которое поможет с семантической разметкой» [Berners-Lee et al, 2001, p. 36], уже имеет в ТАПАЗ конкретное технологическое решение.

Все действующие на данный момент поисковые машины осуществляют поиск либо по ключевым словам, либо по кортежам ключевых слов (ключевые слова в составе именных и/или глагольных групп), используя для этого стандартные программные инструменты предобработки контента и автоматической лексической (тэггер) и синтаксической (парсер) разметки.

Главным недостатком обоих видов поиска является его неточность и, как следствие, необозримость для пользователя громадного количества найденных поисковой машиной электронных адресов сайтов (URL), вынуждающая разработчиков поисковых систем ограничивать зону поиска в Интернете регионом места запроса, что приводит к заведомой неполноте поисковых результатов. Попытки же дополнения поиска по ключевым словам и/или их кортежам контекстуальными синонимами на основе эмпирических онтологий, неверно называемых «семантическими» ${ }^{12}$, лишь увеличивают неточность и неполноту поиска, перегружая поисковую страницу информационным шумом и вызывая у пользователя ощущение недостоверности полученной выборки.

Технология ТАПАЗ предлагает поиск по фрагментам событий или технологическим циклам, которые описываются специальными юнитами, представляющими собой макропроцессы ${ }^{13}$ в сборке, когда специализированные процессы ДЗЗ ставятся по определенному алгоритму в соответствие макропроцессам ТАПАЗ и при этом исчисляются роли всех участников событий ${ }^{14}$.

12 «Функциональные понятия типа “Субъект”, “Предикат” должны тщательно отграничиваться от категориальных понятий, таких как “Именная составляющая”, “Глагол”, и различие между ними не должно быть замаскировано тем обстоятельством, что иногда один и тот же термин используется для понятий обоих видов» [Хомский, 1972, с. 65).

${ }^{13}$ Подчеркнём, что все 112 макропроцессов, то есть исчисленных и закодированных алгеброй ТАПАЗ предельно абстрактных процессов, изоморфичны любой предметной области.

14 «Существуют такие понятия, как “виновник”, “орудие”, “продукт труда” < ..> = Мы находимся здесь в сфере различных категорий, по видимости онтологических, а по существу семантических» [Котарбинский, 1975, с. 31]. 
Такой подход обеспечивает максимальную точность и скорость поиска, релевантность поисковых результатов. Кроме того, он позволяет находить аналогичные технологические циклы в близких (смежных) и дальних предметных областях, оказывая тем самым поддержку пользователю в аналитической деятельности, что значительно расширяет функционал поисковой машины, сдвигая его в сторону изобретающей.

Судя по динамике развития с 2011 года «деятельностно-ориентированной технологии» (activity-based technology) сообществом разработчиков Google, Microsoft, Yahoo и Yandex на международном общественном pecypce Schema.org ${ }^{15}$, а также с 2017 года «технологии Активного словаря» (Activity Vocabulary) ${ }^{16}$, стандартизированной консорциумом W3C в рамках проекта Семантической паутины (Semantic Web) ${ }^{17}$, в ближайшие 10-15 лет основные усилия международных научных и финансовых центров будут сосредоточены на создании графов знаний для автоматического извлечения семантически значимой информации из поисковых страниц, иными словами, на поэтапной разработке формализованного метаязыка, соотносимого по семантической мощности с естественным языком и способного в машиночитаемой форме представлять и преобразовывать знания. Такой метаязык должен уметь оперировать как с самими данными произвольной предметной области, так и с метаданными (правилами оперирования с данными, включая их вывод в Интернет и обратно). Именно от этого зависит переход на седьмой технологический уклад.

\section{Список источников}

1. Альтшуллер Г. Найти идею: введение в ТРИЗ - теорию решения изобретательских задач. - М. : Альпина Бизнес Букс, 2007. — 400 с.

2. Виноград Т. Программа, понимающая естественный язык. — М. : Мир, 1976. — 294 с.

3. Волошина О. А. О структуре и лингвистической терминологии грамматики Панини и её влиянии на европейскую лингвистику // Вестник Российского государственного гуманитарного университета. Сер.: История. Филология. Культурология. Востоковедение. - 2010. — № 9 (52). C. $161-172$.

4. Гордей А. Н. Процедуральная семантика и исчисление предметных областей // Язык: семантика, синтактика, прагматика : материалы I Междунар. науч. конф. / отв. ред. Д. Г. Богушевич. Минск : Минск. гос. лингвист. ун-т, 1995. - Ч. 1. - С. 16-17.

5. Гордей А. Н. Дедуктивная теория языка. - Минск : Беларуская навука, 1998a. — 46 c.

6. Гордей А. Н. Принципы исчисления семантики предметных областей. - Минск : Белорус. гос. ун-т, 1998б. - $156 \mathrm{c.}$

7. Гордей А. Н. Части языка вместо частей речи // Язык. Глагол. Предложение. - Смоленск : Смолен. гос. пед. ун-т, 2000. - С. 258-271.

8. Гордей А. Н. Парадигма частей языка // Словообразование и номинативная деривация в славянских языках : материалы VIII Междунар. науч. конф. — Гродно : Гроднен. гос. ун-т, 2003. — C. $173-179$.

9. Гордей А. Н. Части языка и процедуры их разграничения // Пути Поднебесной. - Минск : Белорус. гос. ун-т, 2006. - Вып. 1, ч. 1. - С. 69-75.

10. Гордей А. Н. Виртуальная цепь как синтаксический код предложения (на примере китайского языка) // Язык, общество и проблемы межкультурной коммуникации : материалы Междунар. науч. конф. : в 2 ч. / отв. ред. Л. М. Середа. - Гродно : Гроднен. гос. ун-т, 2007. - Ч. 2. — С. 349-358.

11. Гордей А. Н. Значение логических и семантических парадоксов для теории языка // Карповские научные чтения : сб. науч. ст. : в 2 ч. / отв. ред. А. И. Головня. - Ч. 1. — Минск : Бел. Дом печати, 2011. - С. 9-18.

12. Гордей А. Н. Динамический синтаксис в семантическом представлении // Иностранные языки в высшей школе. — Рязань : Ряз. гос. ун-т им. С. А. Есенина, 2017. — Вып. 4 (43). — С. $26-34$.

\footnotetext{
${ }^{15}$ CM.: Schema.org Vocabulary, version 8.0.

${ }^{16}$ См.: Activity Vocabulary. W3C Recommendation.

${ }^{17}$ CM.: Semantic Web.
} 
13. Карасева К. В. Принципы декодирования китайских логограмм и реконструкция их семантики. — Минск : Респ. ин-т высш. шк., 2014. — 202 с.

14. Котарбинский Т. Трактат о хорошей работе. - М. : Экономика, 1975. — 271 с.

15. Кругликова Л. Е. «Большой академический словарь русского языка»как продолжатель традиций русской академической лексикографии ("el gran diccionario académico de la lengua rusa" como continuador de las tradiciones de la lexicografía académica rusa) // Cuadernos de Rusística Española. 2012. - № 8. - C. 177-198.

16. Мартынов В. В. Кибернетика. Семиотика. Лингвистика. - Минск : Наука и техника, 1966. - $148 \mathrm{c}$.

17. Мартынов В. В. Семиологические основы информатики. - Минск : Наука и техника, 1974. - $192 \mathrm{c}$.

18. Мартынов В. В. Универсальный семантический код. Грамматика. Словарь. Тексты. Минск : Наука и техника, 1977. — 191 с.

19. Мартынов В. В. Универсальный семантический код: УСК-3. - Минск : Наука и техника, 1984. - $134 \mathrm{c}$.

20. Мартынов В. В. Универсальный семантический код: УСК-4. - Минск : Наука и техника, 1988. - 30 с. (Препринт / Ин-т языкознания АН Белорусской ССР; № 2).

21. Мартынов В. В. Основы семантического кодирования. Опыт представления и преобразования знаний. - Минск : Европ. гуманит. ун-т, 2001. — 140 с.

22. Риппа С. П., Ляшенко О. Н. Семантические платформы программного обеспечения баз знаний в информатике // Праці Одеського політехнічного університету. - Одеса : ОПУ, 2013. Вип. 1(40). - С. 91-96.

23. Руденко Н. И. Языковые категории интенсивности и экстенсивности (на примере китайского языка). - Минск : Респ. ин-т высш. шк., 2010. — 178 с.

24. Святощик М. И. Перевод многообъектной семантики в однообъектную как способ минимизации семантических вычислений // Учёные записки Витебского государственного университета им. П. М. Машерова : сб. науч. тр. - Витебск, 2020. - Т. 31. — С. 180-184.

25. Топоров В. Н. О некоторых аналогиях к проблемам и методам современного языкознания в трудах древнеиндийских грамматиков // Краткие сообщения Института народов Азии. - М. : АН СССР, 1961. - Вып. 57. - С. 123-133.

26. Филлмор Ч. Дело о падеже // Новое в зарубежной лингвистике. — Вып. 10 : Лингвистическая семантика. - М. : Прогресс, 1981a.-С. 369-485.

27. Филлмор Ч. Дело о падеже открывается вновь // Новое в зарубежной лингвистике. Вып.10 : Лингвистическая семантика. - М. : Прогресс, 1981б.- С. 496-530.

28. Филлмор Ч. Основные проблемы лексической семантики // Новое в зарубежной лингвистике. — Вып. 12 : Прикладная лингвистика. - М. : Радуга, 1983. — С. 74-122.

29. Филлмор Ч. Фреймы и семантика понимания // Новое в зарубежной лингвистике. - М. : Прогресс, 1988. - Вып. 23. - С. 52-92.

30. Хомский Н. Аспекты теории синтаксиса. - М. : Моск. гос. ун-т, 1972. - 258 с.

31. Хэррис 3. С. Совместная встречаемость и трансформация в языковой структуре // Новое в лингвистике. — М. : Ин. лит., 1962. — Вып. 2. - С. 528-636.

32. Aarts B. English syntax and argumentation. - 2nd ed. - Houndmills, Basingstoke, Hampshire, New York : Palgrave (Macmillan), 2001. - 312 p.

33. Activity Vocabulary. W3C Recommendation. — URL : https://www.w3.org/TR/activitystreamsvocabulary/\#dfn-activity (дата обращения: 18.04.2021).

34. Ashtadhyayi or Sutrapath of Panini. — URL : https://sanskritdocuments.org/doc_z_misc major_works/aShTAdhy_AyI.pdf (дата обращения: 18.04.2021).

35. Berners-Lee T., Hendler J., Lassila O. The Semantic Web: A new form of Web content that is meaningful to computers will unleash a revolution of new possibilities // Scientific American. - 2001. Vol. 284. - Iss. 5. - Pp. 34-43.

36. Chomsky N. Lectures on Government and Binding: The Pisa Lectures // Studies in Generative Grammar. - New Jersey : Foris Publications, Dordrecht and Cinnaminson, 1981. — No. 9. - Pp. 1-371.

37. Fillmore Ch. J. Frame semantics and the nature of language // Annals of the New York Academy of Sciences: Conference on the Origin and Development of Language and Speech. — 1976. Vol. 280. - Pp. 20-32. 
38. Fillmore Ch. J. Frame semantics // Linguistics in the Morning Calm. - Seoul : Hanshin Publishing Co., 1982. - Pp. 111-137.

39. Fillmore Ch. J., Atkins B. T. S. Starting where the dictionaries stop: The challenge for computational lexicography // Computational Approaches to the Lexicon. - Oxford : Oxford University Press, 1994. - Pp. 349-393.

40. Golenkov V., Gulyakina N., Grakova N., Davydenko I., Nikulenka V., Eremeev A., Tarasov V. From training intelligent systems to training their development tools // Golenkov V. V. et al. (eds.) Open Semantic Technologies for Intelligent Systems (OSTIS) : Conference. — Minsk : Belarussian State University of Informatics and Radioelectronics Publ., 2018. — Iss. 2. - Pp. 81-98.

41. Hardzei A. Theory for Automatic Generation of Knowledge Architecture: TAPAZ-2 / Transl. from Rus. I. M. Boyko. - Rev. English edn. - Minsk : Republ. Inst. of High School, 2017. — 50 p. URL : http://tapaz.by (дата обращения: 18.04.2021).

42. Hardzei A., Udovichenko A. Graph of TAPAZ-2 Semantic Classifier // Golenkov V. V. et al. (eds.) Open Semantic Technologies for Intelligent Systems (OSTIS) : Conference. — Minsk: Belarussian State University of Informatics and Radioelectronics Publ., 2019. - Iss. 3. - Pp. 281-284. - URL : http://tapaz.by/\#/articles (дата обращения: 18.04.2021).

43. Hardzei A., Krapivin Y. Perspective Approaches to Semantic Knowledge Representation and their Applications in the Context of the Task of Automatic Identification of the Semantically Equivalent Fragments of the Text Documents // Golenkov V. V. et al. (eds.) Open Semantic Technologies for Intelligent Systems (OSTIS) : Conference. - Minsk : Belarussian State University of Informatics and Radioelectronics Publ., 2020. - Iss. 4. - Pp. 183-188.

44. Harris Z. S. String Analysis of Sentence Structure. - The Hague : Mouton, 1962. - 251 p.

45. Hinton G. E. Boltzmann machine // Scholarpedia. - 2007. — N 2 (5). - P. 1668. - URL : http://www.scholarpedia.org/article/Boltzmann_machine (дата обращения: 18.04.2021).

46. Hinton G. E., Salakhutdinov R. R. Reducing the dimensionality of data with neural networks // Science. - 2006. - Vol. 313, N 5786. - Pp. 504-507.

47. Jackendoff R. Semantic Interpretation in Generative Grammar. - Cambridge, MA : MIT Press., 1972. $-400 \mathrm{p}$.

48. Jackendoff R. X-bar Syntax: A Study of Phrase Structure. - Cambridge, MA : MIT Press., 1977. - $249 \mathrm{p}$.

49. Lakoff G. Instrumental Adverbs and the Concept of Deep Structure // Foundations of Language. - 1968. - N 4 (1). - Pp. 4-29.

50. Martynov V. V. Universal Semantic Code: USC-5. - Minsk : MSLU, 1995. - 21 p. (Pre-print / MSLU; N 4).

51. Montague R. Formal Philosophy: Selected Papers of Richard Montague. - New Haven ; London: Yale University Press, 1974. - Pp. 222-247. 18.04.2021).

52. Schema.org Vocabulary, version 8.0. — URL : https://schema.org. (дата обращения:

53. Semantic Web. - URL : https://www.w3.org/standards/semanticweb. (дата обращения: 18.04.2021).

54. Stowell T. A. Origins of phrase structure. Thesis (Ph. D.) Massachusetts Institute of Technology, Dept. of Linguistics and Philosophy, 1981. - 496 p. — URL : http://www.ai.mit.edu/projects/ $\mathrm{dm} /$ theses/stowell81.pdf. (дата обращения: 18.04.2021).

55. Tesnière L. Éléments De Syntaxe Structurale. — Paris : Librairie C. Klincksieck, 1959. — 671 p.

\section{References}

1. Altshuller H. Nayti ideyu: Vvedeniye v TRIZ — teoriyu resheniya izobretatel'skikh zadach [Find an Idea: Introduction to TRIZ - Theory of Inventive Problem Solving]. Moscow, Alpina Business Books Publ., 2007, 400 p. (In Russian).

2. Winograd T. Programma, ponimayushchaya yestestvennyy yazyk [A program that understands natural language]. Moscow, World Publ., 1976, 294 p. (In Russian).

3. Voloshina O. A. On the structure and linguistic terminology of Panini's grammar and its influence on European linguistics. Vestnik RGGU. Seriya: Istoriya. Filologiya. Kul'turologiya. Vostokovedeniye [Bulletin of the Russian State University for the Humanities. Series: History. Philology. Culturology. Oriental studies]. 2010, no. 9 (52), pp. 161-172. (In Russian). 
4. Hardzei A. Procedural Semantics and Evaluation of Subject Domains. Materialy I Mezhdunarodnoy nauchnoy konferentsii "Yazyk: semantika, sintaktika, pragmatika" [Proceedings of I International Research Conference "Language: semantics, syntactics, pragmatics". Minsk, Minsk State Linguistic University Publ., 1995, pt. 1, pp. 16-17. (In Russian).

5. Hardzei A. Deduktivnaya teoriya yazyka [Deductive Theory of Language]. Minsk, Belarussian Science Publ., 1998a, 46 p. (In Russian).

6. Hardzei A. Printsipy ischisleniya semantiki predmetnykh oblastei [The Principles of Evaluating the Semantics of Subject Domains]. Minsk, Belarusian State University Publ., 1998b, 156 p. (In Russian).

7. Hardzei A. Parts of Language Instead of Parts of Speech. Yazyk. Glagol. Predlozheniye [Language. Verb. Sentence]. Smolensk, Smolensk Pedagogical State University Publ., 2000, pp. 258-271. (In Russian).

8. Hardzei A. The Paradigm of Parts of the Language. Materially VIII Mezhdunarodnoy konferentsii "Slovoobrazovaniye i nominativenaya derivatsiya v slavyanskikh yazykakh" [Proceedings of VIII International Research Conference "Word-Building and Nominative Derivation in Slavik Languages"]. Grodno, Grodno State University Publ., 2003, pp. 173-179. (In Russian).

9. Hardzei A. Parts of Language and the Procedures of Its Delineation. Puti Podnebesnoi [The Paths of the Middle Kingdom]. Minsk, Belarusian State University Publ., 2006, iss. 1, pt. 1, pp. 69-75. (In Russian).

10. Hardzei A. Virtual String as a Syntactical Code of a Sentence (by the examples of the Chinese language). Materialy mezhdunarodnoy nauchnoy konferentsii "Yazyk, obshchestvo i problemy mezhkul'turnoy kommunikatsii" [Proceedings of International Research Conference "Language, society and problems of intercultural communication"]. Grodno, Grodno State University Publ., 2007, pt. 2, pp. 349-358. (In Russian).

11. Hardzei A. The Meaning of Logical and Semantic Paradoxes for Language Theory. Karpovskiye nauchnye chteniya [Readings from V. A. Karpov]. Collection of Research Papers in 2 parts. Minsk, Belarussian State University Publ., 2011, pt. 1, pp. 9-18. (In Russian).

12. Hardzei A. Dynamic Syntax: a Semantic View. Inostrannyye yazyki v vysshey shkole [Foreign languages in Higher School]. Ryazan, Ryazan State University Publ., 2017, iss. 4(43), pp. 26-34. (In Russian).

13. Karaseva K. V. Printsipy dekodirovaniya kitaiskikh logogram i rekonstruktsiya ikh semantiki [The Principles of Decoding Chinese Logograms and Reconstruction of Their Semantics]. Minsk, The Republican Institute of Higher School Publ., 2014, 202 p. (In Russian).

14. Kotarbinski T. Traktat o khoroshey rabote [Treatise on Good Work]. Moscow, Economics Publ., 1975, 271 p. (In Russian).

15. Kruglikova L. E. "The Big Academic Dictionary of the Russian Language" as a follower of the traditions of Russian academic lexicography ("el gran diccionario académico de la lengua rusa" como continuador de las tradiciones de la lexicografía académica rusa). Cuadernos de Rusística Española, 2012, no. 8, pp. 177-198. (In Russian).

16. Martynov V. V. Kibernetika. Semiotika. Lingvistika [Cybernetics. Semiotics. Linguistics]. Minsk, Science and Technics Publ., 1966, 148 p. (In Russian).

17. Martynov V. V. Semiologicheskie osnovy informatiki [Semeiological Foundations of Computer Science]. Minsk, Science and Technology Publ., 1974, 192 p. (In Russian).

18. Martynov V. V. Universal 'nyy semanticheskiy kod. Grammatika. Slovar'. Teksty [Universal Semantic Code. Grammar. Dictionary, Texts]. Minsk, Science and Technics Publ., 1977, 191 p. (In Russian).

19. Martynov V. V. Universal'nyy semanticheskiy kod: USK-3 [Universal Semantic Code: USC-3]. Minsk, Science and Technics Publ., 1984, 134 p. (In Russian).

20. Martynov V. V. Universal'nyy semanticheskiy kod: USK-4 [Universal Semantic Code: USC-4]. Preprint, no 2 / Institute of Linguistics of Academy of Science of BSSR. Minsk, Science and Technics Publ., 1988, 30 p. (In Russian).

21. Martynov V. V. Osnovy semanticheskogo kodirovaniya. Opyt predstavleniya i preobrazovaniya znaniy [Foundations of Semantic Coding. Experience of Knowledge Representation and Transformation]. Minsk, European Humanitarian University Publ., 2001, 140 p. (In Russian).

22. Rippa S. P., Lyashenko O. M. Semantic platforms of knowledge bases software in informatics. Pratsi Odes 'koho politekhnichnoho universytetu [Proceedings of Odessa Polytechnic University]. Odessa, Odessa Polytechnic University Publ., 2013, vol. 1(40), pp. 91-96. (In Russian).

23. Rudenko N. I. Yazykovye kategorii intensivnosti i ekstensivnosti (na primere kitaiskogo yazyka) [The Language Categories of Intensity and Extensity (exemplified by the Chinese language)]. Minsk, Republican Institute of Higher School Publ., 2010, 178 p. (In Russian). 
24. Svyatoshchik M. I. Translating Multi-Object Semantics into Single-Object Semantics as a Method of Minimizing Semantic Calculation. Uchonyye zapiski VGU im. P. M. Masherova : sb. nauch. trudov [Scientific notes of Vitebsk State University named after P. M. Masherov : collection of scientific papers]. Vitebsk, Vitebsk State University Publ., 2020, vol. 31, pp. 180-184. (In Russian).

25. Toporov V. N. On some analogies to the problems and methods of modern linguistics in the works of ancient Indian grammarians. Kratkiye soobshcheniya Instituta narodov Azii [Briefs of the Institute of the Peoples of Asia]. Moscow, USSR Academy of Sciences Publ., 1961, iss. 57, pp. 123-133. (In Russian).

26. Fillmore Ch. J. The case for case. Novoye v zarubezhnoi lingvistike [New Research in Foreign Linguistics]. Moscow, Progress Publ., 1981a, iss. 10. Lingvisticheskaya semantika [Linguistic semantics], pp. 369-485. (In Russian).

27. Fillmore Ch. J. The case for case reopened. Novoye $v$ zarubezhnoi lingvistike [New Research in Foreign Linguistics]. Moscow, Progress Publ., 1981b, iss. 10. Lingvisticheskaya semantika [Linguistic semantics], pp. 496-530. (In Russian).

28. Fillmore Ch. J. Basic problems of lexical semantics. Novoye v zarubezhnoi lingvistike [New Research in Foreign Linguistics]. Moscow, Rainbow Publ., 1983, iss. 12. Prikladnaya lingvistika [Applied Linguistics], pp. 74-122. (In Russian).

29. Fillmore Ch. J. Frames and the semantics of understanding. Novoye v zarubezhnoi lingvistike [New Research in Foreign Linguistics]. Moscow, Progress Publ., 1988, iss. 23, pp. 52-92. (In Russian).

30. Chomsky N. Aspekty teorii sintaksisa [Aspects of the Theory of Syntax]. Moscow, Moscow University Press, 1972, 258 p. (In Russian).

31. Harris Z.S. Co-occurrence and transformation in linguistic structure. Novoye $v$ lingvistike [New Research in Linguistics]. Moscow, Foreign Literature Publ., 1962, iss. 2, pp. 528-636. (In Russian).

32. Aarts B. English syntax and argumentation. 2nd edn. Houndmills, Basingstoke, Hampshire, New York, Palgrave (Macmillan), 2001, 312 p.

33. Activity Vocabulary. W3C Recommendation. Available at : https://www.w3.org/TR/activitystreamsvocabulary/\#dfn-activity (accessed 18.04.2021).

34. Ashtadhyayi or Sutrapath of Panini. Available at: https://sanskritdocuments.org/doc_z_misc_ major_works/aShTAdhy_AyI.pdf (accessed 18.04.2021).

35. Berners-Lee T., Hendler J., Lassila O. The Semantic Web: A new form of Web content that is meaningful to computers will unleash a revolution of new possibilities. Scientific American. 2001, vol. 284, iss. 5, pp. 34-43.

36. Chomsky N. Lectures on Government and Binding: The Pisa Lectures. Studies in Generative Grammar. New Jersey, Foris Publications, Dordrecht and Cinnaminson, 1981, no. 9, pp. 1-371.

37. Fillmore Ch. J. Frame semantics and the nature of language. Annals of the New York Academy of Sciences: Conference on the Origin and Development of Language and Speech. 1976, vol. 280, pp. 20-32.

38. Fillmore Ch. J. Frame semantics. Linguistics in the Morning Calm. Seoul, Hanshin Publishing Co., 1982, pp. 111-137.

39. Fillmore Ch. J., Atkins B. T. S. Starting where the dictionaries stop: The challenge for computational lexicography. Computational Approaches to the Lexicon. Oxford, Oxford University Press, 1994, pp. 349-393.

40. Golenkov V., Gulyakina N., Grakova N., Davydenko I., Nikulenka V., Eremeev A., Tarasov V. From training intelligent systems to training their development tools. Golenkov V. V. et al. (eds.). Open Semantic Technologies for Intelligent Systems (OSTIS). Minsk, Belarussian State University of Informatics and Radioelectronics Publ., 2018, iss. 2, pp. 81-98.

41. Hardzei A. Theory for Automatic Generation of Knowledge Architecture: TAPAZ-2 / Transl. from Rus. I. M. Boyko. Rev. English edn. Minsk, The Republican Institute of Higher School Publ., 2017, 50 p. Available at : http://tapaz.by. (accessed 18.04.2021).

42. Hardzei A., Udovichenko A. Graph of TAPAZ-2 Semantic Classifier. Golenkov V. V. et al. (eds.). Open Semantic Technologies for Intelligent Systems (OSTIS). Minsk, Belarussian State University of Informatics and Radioelectronics Publ., 2019, iss. 3, pp. 281-284. Available at: http://tapaz.by/\#/ articles. (accessed 18.04.2021).

43. Hardzei A., Krapivin Y. Perspective Approaches to Semantic Knowledge Representation and their Applications in the Context of the Task of Automatic Identification of the Semantically Equivalent Fragments of the Text Documents. Golenkov V. V. et al. (eds.). Open Semantic Technologies for Intelligent Systems (OSTIS). Minsk, Belarussian State University of Informatics and Radioelectronics Publ., 2020 , iss. 4, pp. $183-188$. 
44. Harris Z. S. String Analysis of Sentence Structure. The Hague, Mouton, 1962, 251 p.

45. Hinton G. E. Boltzmann machine. Scholarpedia. 2007, 2(5):1668. Available at : http://www. scholarpedia.org/article/Boltzmann_machine (accessed 18.04.2021).

46. Hinton G. E., Salakhutdinov R. R. Reducing the dimensionality of data with neural networks. Science. 2006, vol. 313, no. 5786, pp. 504-507.

47. Jackendoff R. Semantic Interpretation in Generative Grammar. Cambridge, MA, MIT Press., $1972,400 \mathrm{p}$.

48. Jackendoff R. X-bar Syntax: A Study of Phrase Structure. Cambridge, MA, MIT Press., 1977, $249 \mathrm{p}$.

49. Lakoff G. Instrumental Adverbs and the Concept of Deep Structure. Foundations of Language. 1968, no 4 (1), pp. 4-29.

50. Martynov V. V. Universal Semantic Code: USC-5. Minsk, MSLU, 1995, 21 p. (Pre-print. MSLU; no. 4).

51. Montague R. Formal Philosophy: Selected Papers of Richard Montague. New Haven, London, Yale University Press, 1974, pp. 222-247.

52. Schema.org Vocabulary, version 8.0. Available at : https://schema.org. (accessed 18.04.2021).

53. Semantic Web. Available at: https://www.w3.org/standards/semanticweb. (accessed 18.04.2021).

54. Stowell T. A. Origins of phrase structure. Thesis (Ph. D.) Massachusetts Institute of Technology, Dept. of Linguistics and Philosophy, 1981, 496 p. Available at : http://www.ai.mit.edu/projects/dm/ theses/stowell81.pdf (accessed 18.04.2021). (In French).

55. Tesnière L. Éléments De Syntaxe Structurale. Paris, Librairie C. Klincksieck, 1959, 671 p.

\section{Информация об авторе}

Гордей Александр Николаевич - доктор филологических наук, профессор, директор Минского городского научно-педагогического центра «Тайген», заведующий кафедрой теории и практики китайского языка Минского государственного лингвистического университета, профессор кафедры языкознания и страноведения Востока Белорусского государственного университета. Почтовый адрес: 220117, Республика Беларусь, г. Минск, пр-т им. газеты «Звезда», д. 48, кв. 108. Тел.: $+375-29-674-66-88$.

\section{Information about the author}

Hardzei Aliaksandr - Doctor of Philology, Professor, Director of Minsk City Scientific and Pedagogic Center "Taigen", Head of the Department of Theory and Practice of Chinese Language at Minsk State Linguistic University, Professor of Oriental Language \& Country Studies' Department of Belarusian State University. Postal address: 48-108 Zviazda Av., Minsk, Belarus, 220117. Tel.: +375-29-674-66-88. E-mail: alieks2001@yahoo.com

Статья поступила в редакциию 22.04.2021;

одобрена после рецензирования 25.04.2021;

принята к публикации 24.01.2021.

Submitted 22.04.2021;

approved after reviewing 25.04.2021;

accepted for publication 25.04.2021. 
Иностранные языки в высшей школе. 2021. № 2 (57). С. 27-33.

Foreign Languages in Tertiary Education. 2021;2(57):27-33.

Научная статья

УДК 811.112 .2

DOI: $10.37724 /$ RSU.2021.57.2.002

\title{
Концепты Spiel (игра) и Kampf (борьба) \\ в структуре концептосферы силы \\ в немецкой философской традиции
}

\author{
Валентин Николаевич Степанов \\ Международная академия бизнеса и новых технологий, Ярославль, Россия \\ stepanov@mubint.ru
}

Аннотация. В статье рассматривается семантическое пространство концептов “Spiel” («игра») и “Катрf” («борьба»), которое, как показало исследование, достаточно полно и системно структурировано. Концептосфера “Spiel” («игра») и “Катрf” («борьба») выявлена по базисным пропозициям с опорой на лексическое значение слов и контексты их употребления в соответствии с репрезентациями пяти базисных фреймов: предметного, акционального, посессивного, идентификационного, компаративного. Количественное измерение концептов определяется в соответствии с лексикографическим описанием: оппозиция форм единственного и множественного числа зафиксирована в словарях и подтверждается в корпусе выбранных для анализа текстов и языковых контекстов. В квалитативном, качественном, отношении концепты оцениваются нейтрально. Локативные характеристики представлены у концепта “Spiel”. В схемах контактного действия "Spiel” («игра») и “Каmpf” («борьба») выступают в нескольких ролях - объекта и медиатива. В качестве субъектов “Spiel” («игра») и “Катрf” («борьба») выступают базовые концепты “Kraft” («сила») и “Macht” («власть»). Ханна Арендт определяет борьбу в качестве родового признака политики - «борьба за власть» (ради власти). Борьба в ее представлении может выступать родовым признаком жизни (Leben). Мишель Фуко определял власть через родовой признак как игру (Spiel), которая в непрерывных столкновениях и противостояниях (Kämpfen) соотношение сил преобразует, усиливает и извращает. Борьба (Каmpf), по мнению Фуко, выступает средством игры (Spiel), в определенном смысле - ее формой.

Ключевые слова: концептосфера, концепт, Spiel, игра, Kampf, борьба, лингвальные сети, фрейм.

Для цитирования: Степанов В. Н. Концепты Spiel (игра) и Каmpf (борьба) в структуре концептосферы силы в немецкой философской традиции // Иностранные языки в высшей школе. 2021. № 2 (57). C. 27-33. DOI: 10.37724/RSU.2021.57.2.002.

Original article

\section{The Concepts of Spiel (playing) и Kampf (struggle) within the Structure of the Conceptual Sphere of Power in the German Philosophic Tradition}

\author{
Valentin N. Stepanov \\ International Academy of Business and New Technologies, Yaroslavl, Russia \\ stepanov@mubint.ru
}

Abstract. The paper examines semantic space occupied by the concepts of "Spiel" («game») and "Kampf" («struggle»), which, as the research shows, is comprehensively and systemically structured. The conceptual sphere of "Spiel" and "Kampf" is elicited with consideration of the basic propositions, proceeding from the lexical meaning of the words and the contexts of their usage, according to the representations of the five

(C) Степанов В. Н., 2021 
basic frames (subject-focused, actional, possessive, identificational, comparative). The quantitative evaluation of the concepts is determined according to their lexicographic descriptions: opposition of the singular and plural forms is registered in dictionaries and confirmed by the corpus of texts and language contexts selected for analysis. From the qualitative and quantitative perspectives, the concepts are assessed neutrally. Locative characteristics are found in the concept of "Spiel". In the patterns of contact interaction, "Spiel" and "Kampf" perform several roles those of the object and the mediative. The role of the Subject for "Spiel" and "Kampf" is performed by the basic concepts of "Kraft" (force) and "Macht" (power). Hannah Arendt sees struggle as the generic feature of politics - "struggle for power" (for the sake of power). And power, as she sees it, might act as the generic feature of life (Leben). Michel Foucault defined power by its generic feature as a game (Spiel), which, in the course of incessant conflicts and oppositions, transforms, enhances or distorts the balance of powers. Struggle (Kampf), from Foucault's viewpoint, is a means of playing (Spiel), and, in a certain sense, is its form.

Keywords: conceptual sphere, concept, Spiel, playing, Kampf, struggle, lingual networks, frame.

For citation: Stepanov V. N. The Concepts of Spiel (playing) и Kampf (struggle) within the Structure of the Conceptual Sphere of Power in the German Philosophic Tradition. Foreign Languages in Tertiary Education. 2021;2(57):27-33. (In Russ.). DOI: 10.37724/RSU.2021.57.2.002.

Рассматриваемые в данной статье концепты “Spiel” («игра») и “Kampf” («борьба») входят в состав концептосферы силы [Степанов, 2016]. Дискурс силы реконструируется с точки зрения институциональных характеристик как интердискурсное образование, интегрирующее дискурсы нескольких предметных сфер - философии, культурологии, политологии, языкознания. В интенциональном ключе дискурс силы является дискурсом влияния, проявления духа, власти, мощи, интенциональности. Вес каждого концепта в рамках данной концептосферы определяется его статусом в рамках того или иного институционального дискурса, временем введения в понятийный аппарат соответствующей предметной области, степенью терминологической проработанности и потенциалом терминологической валентности, то есть способностью использоваться для дальнейшего смыслообразования.

Концептосфера как когнитивное образование формируется в ходе познавательной деятельности человека и в результирующей стадии формирования становится инструментом познания для последующих поколений и неотъемлемой частью картины мира человека, тем самым демонстрируя определенный антропогенный потенциал: человек порождает и присваивает концепты в ходе собственной мыслительной деятельности, обогащая «ипостаси» собственной личности.

Язык как инструмент формирования концепта и условие существования концептосферы обеспечивает антропоцентричность концептосферы и ее антропоморфизм, поскольку материалом для ее формирования становятся окружающий человека предметный мир и общественные явления и свойственные человеку формы мыслительной деятельности. Средой объективации концептосферы является текст.

Концептосфера как антропогенное, антропоцентричное и антропоморфное явление выполняет функции эпистемического медиатора, способствует порождению, хранению и передаче (трансляции) знаний, что свидетельствует о наличии у концептосферы черт интеллектуальной личности.

Важными для понимания структуры и объема концептосферы силы выступают концепты “Spiel” («игра») и “Катрf” («борьба»), не содержащие смыслового компонента «сила», но определяющие смыслообразующий контекст концептов в структуре концептосферы.

В качестве методики концептуального анализа "Spiel” («игра») и “Kampf” («борьба») выбрана модель описания семантики лингвальных сетей (СЛС) С. А. Жаботинской. Для моделирования концептуальных структур и когнитивных операций используется набор обобщенных понятийных структур (базисных пропозиций), отслеживаемых в значениях и формах языковых единиц разных уровней. Базисные пропозиции выделяются с опорой на лексическое значение слов и контексты их употребления, имеют наивысший уровень обобщения, или схемности, представляют собой изначальные категории мышления и типы 
отношений между ними. Тип пропозицональной схемы определяется по ее принадлежности к одному из пяти базисных фреймов - предметному, акциональному, посессивному, идентификационному, компаративному. Концептосферой в этом ключе называется все структурируемое семантическое пространство.

Предметный фрейм “Spiel” («игра») и “Kampf” («борьба») описывается с помощью трех бытийных (пропозициональных) схем - квантитативной, квалитативной, локативной. Пропозициональные схемы темпоральная и способа бытия в представленных контекстах не выявлены.

В квантитативном отношении («Х есть СТОЛЬКО-количество») количественное измерение концептов “Spiel” («игра») и “Kampf” («борьба») определяется в соответствии с лексикографическим описанием: оппозиция форм единственного и множественного числа (“Spiel” - "Spiele”, "Kampf” — "Kämpfe”) зафиксирована в словарях и подтверждается в корпусе выбранных для анализа текстов и языковых контекстов:

- "die immerwährenden lokalen Kämpfe zu institutionalisierter Macht sollten konsolidieren können" [Habermas, 1985, S. 336];

- "Machtspiel" [Luhmann, 2012, S. 127] — "Kriegsspielen" [Arendt, 1970, S. 7];

- "Machtkampf" [Luhmann, 2012, S. 60] — "Interessenkämpfen" [Arendt, 1970, S. 23].

В квалитативном, качественном, отночении («Х есть ТАКОЕ-качество») “Spiel” («игра») и “Катрf” («борьба») оцениваются нейтрально.

С помощью концепта “Spiel” И. Кант в «Критике способности суждения» описывает состояние сил, их атрибуты, например: “spielende Einbildungskraft” («играющее воображение») [Kant, 1974, В. 1, S. 165], "im Spiele der Gemütskräfte” («в игре сил ума») [Ibid., S. 144], "aus dem freien Spiel unsrer Erkenntniskräfte" («из свободной игры наших сил познания») [Ibid., S. 157], “subjektives Spiel der Vorstellungskräfte” [Ibid] («субъективная игра сил

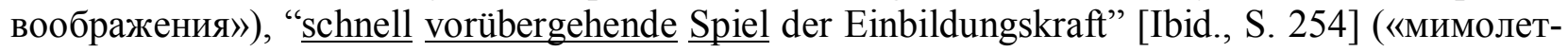
ная игра воображения»).

Нейтральный характер концептов “Spiel” («игра») и “Kampf” («борьба») сохраняется и в современной литературе:

- "des rechnerischen Spiels" [Habermas, 1985, S. 202];

- "unbeantwortbare Anspielungen" [Luhmann, 2012, S. 34];

- "des physisches Kampfes" [Luhmann, 2012, S. 30];

- "die immerwährenden lokalen Kämpfe zu institutionalisierter Macht sollten konsolidieren können" [Habermas, 1985, S. 336];

- "in schwerem Kampf gegen eine Welt feindlicher Mächte" [Weber, 2009, 45].

Локативные характеристики («Х существует/действует ТАМ») представлены у концепта "Spiel”, например: "Spielraum” [Luhmann, 2012, S. 123].

Акциональные фреймы концептов “Spiel” («игра») и “Катpf” («борьба») в исследованных языковых контекстах выявлены с помощью двух акциональных (пропозициональных) схем - контактного действия и каузации. Примеры пропозициональных схем состояния/процесса не выявлены.

В схемах контактного действия "Spiel” («игра») и “Kampf” («борьба») выступают в нескольких ролях — объекта и медиатива.

В качестве субъектов "Spiel” («игра») и “Kampf” («борьба») выступают базовые концепты силы “Kraft” и "Macht":

- "ein Spiel von Kräften" [Habermas, 1985, S. 127];

- "auf das transzendente Spiel der Kräfte" [Ibid, S. 128];

- "das den Kampf der Mächte transzendieren könnte" [Ibid, S. 151].

В немецкой философской традиции принято описывать взаимодействие сил с помощью слова "Spiel” («игра»), начиная с И. Канта, например: Юрген Хабермас использует 
для обозначения этого явления слово “Kräftespiel” («игра сил») [Habermas, 1985], а Райнер Форст - "Spiel der Kräfte” [Forst, 2015]. Хабермас указывал, с одной стороны, на взаимный характер игры ("als Zusammenspiel von Struktur und Ereignis gedacht werden sollte" [Habermas, 1985, S. 285]), а с другой — на ее контрарный характер: “Gegenspiel” [Ibid, S. 161]. При этом исследователь цитирует Мартина Хайдеггера, его труд о Ницше [Heidegger, 1961, Bd. 1, S. 480].

Контрарный характер борьбы ожидаем и представлен в языковых контекстах концепта “Kampf” («борьба»):

- "in schwerem Kampf gegen eine Welt feindlicher Mächte" [Weber, 2009, S. 45];

- Man kann diesen Kampf gegen die (autoritätsfeindlichen) Askese” [Ibid, 2009, S. 271];

- “im Kampf gegen die östlichen Einpartei-Bürokratien” [Arendt, 1970, S. 26].

Немецкий исследователь языка XVIII века Даниэль Йениш в своей работе 1796 года представлял силу как «след» духа, одно из множества его проявлений, а речь соответственно как проявление силы духа. Собственно дух для Йениша не что иное, как определенная, размеренная интеллектуальная по своей природе деятельность, в которой интеллектуальная и смысловая природа устанавливается и утверждается в игре: "Der bestimmte Hang unsers Geistes bei allen seinen Kraftäusserungen, und also auch bei, der Sprache, ist eine gewisse gemächliche Thätigkeit, wodurch der intellektuelle sowohl, als der sinnliche Theil seiner Natur, auf eine ihm angehneme Weise ins Spiel gesetzt wird" [Jenisch, 1796, S. 4-5].

Медиативное значение в концептах "Spiel” («игра») и “Kampf” («борьба») признается и современными исследованиями. Хабермас отмечает опосредующую роль игры в манифестации «воли к власти» (“Machtwill”): “...und schenkende Aktivität eines Machtwillens, der sich in Spiel, Tanz, Überschwang und Taumel ebenso manifestiert... werden" [Habermas, 1985, S. 124]. Вебер указывает на аналогичную роль борьбы: “... in schwerem Kampf gegen eine Welt feindlicher Mächte" [Weber, 2009, S. 45]. Ханна Арендт цитирует американского социолога и определяет политику как борьбу за власть (ради власти): “Alle Politik ist Kampf um die Macht" [Arendt, 1970, S. 36 ; Mills, 1956, S. 171]. Она же упоминает американскую борьбу за гражданские права: “...mit dem Kampf um die Bürgerrechte” [Arendt, 1970, S. 18].

Слова "Spiel” («игра») и "Kampf” («борьба») употребляются как детерминаты в эндоцентрических гипотактических композитах, в которых конституэнты связаны подчинительными (неравноправными, гипотактическими) отношениями, в данном случае отношениями соподчинения, когда детерминат (Determinatum) определяется через детерминант (Determinans) по семантической модели причинной связи Nomina causalia - «В ради А»:

- "Lichtspiel”" («игра света») [Weber, 2009, S. 22];

- "Sprachspiele" («языковые игры / игры языка») [Habermas, 1985, S. 234];

- "der Grammatik eines Sprachspiels” («языковая игра / игра языка») [Ibid, S. 183];

- “Kräftespiel” («силовая игра / игра сил») [Ibid, S. 425];

- “Machtspiel” («игра власти») [Luhmann, 2012, S. 127];

- "Kriegsspielen” («военная игра / игра войны») [Arendt, 1970, S. 7];

- “Machtkampf”" («борьба власти») [Luhmann, 2012, S. 60];

- “Interessenkämpfen” («борьба интересов») [Arendt, 1970, S. 23];

- “Klassenkampf” («борьба классов / классовая борьба») [Ibid., S. 70].

В текстах встречается использование слов “Spiel” («игра») и “Kampf” («борьба») как детерминанта в эндоцентрической гипотактической композите для характеристики детермината по семантической модели Nomina patientis - «А с целью В». При этом игра и борьба выступают в семантической роли пациенса и сами становятся объектами действия с целью выражения, в частности, «духа» (“Geist”), «значения» (“Bedeutung”), «знака» (“Marke”), «теории» (“Theorie”), «средства» (“Mittel”), «соглашения» (“Konvention”), «правила» (“Regel”), «пространства» (“Raum”): 
- "Kampfgeist" [Arendt, 1970, S. 71];

- "Spielbedeutung", "Spielmarken” [Habermas, 1985, S. 202];

- "Spieltheorien" [Arendt, 1970, S. 8];

- "Kampfmitteln" [Ibid, 1970, S. 14];

- "Spielkonventionen von Handlungsnormen" [Habermas, 1985, S. 230];

- "Spielregeln" [Ibid, 1985, S. 74];

- "Spielraum" [Luhmann, 2012, S. 123].

Посессивный фрейм концептов “Spiel” («игра») и “Катрf” («борьба») в исследованных контекстах не представлен.

Идентификационный фрейм концептов “Spiel” («игра») и “Kampf” («борьба») объединяет идентификационные схемы классификации (отношения «род - вид», неопределенности) и не представлен пропозициональными схемами персонификации и характеризации.

Как уже было отмечено выше, Ханна Арендт определяет вслед за американским социологом именно борьбу в качестве родового признака политики - «борьбу за власть» (ради власти): “Alle Politik ist Kampf um die Macht” [Arendt, 1970, S. 36 ; Mills, 1956, S. 171]. Гипотетически борьба в представлении Арендт может выступать родовым признаком жизни: “... alles Leben ein nie anderer Kampf... sei” [Arendt, 1970, S. 70].

Мишель Фуко свое понимание власти связывал с силой. Он определял власть как многообразие (Vielfältigkeit) «соотношения сил» (Kraftverhältniss), которые населяют и структурируют территорию, и как игру, которая в непрерывных столкновениях и противостояниях (Kämpfen) эти соотношения сил преобразует, усиливает и извращает. Власть - это название, как считает Фуко, которое человек дал сложному стратегическому процессу в обществе: “...die Vielfältigkeit von Kraftverhältniss, die ein Gebiet bevölkern und organisieren; das Spiel, das in unaufhörlichen Kämpfen und Auseinandersetzungen diese Kraftverhältnisse verwandelt, verstärkt, verkehrt. $<\ldots .>$. Weil sie von überall kommt, ist die Macht überall. <...> Die Macht ist der Name, den man einer komplexen strategischen Situation in einer Gesellschaft gibt“" [Foucault, 1983, S. 93]. Примечательно в данном определении то, что борьба (Kampf), по мнению Фуко, выступает средством игры (Spiel), в определенном смысле - ее формой.

Компаративный фрейм концептов "Spiel” («игра») и "Катрf” («борьба») в исследованных контекстах не представлен.

В заключение необходимо отметить, что семантическое пространство концептов “Spiel” («игра») и “Катрf” («борьба») достаточно полно и системно структурировано. Концептосфера "Spiel” («игра») и “Катрf” («борьба») выявлена по базисным пропозициям с опорой на лексическое значение слов и контексты их употребления в соответствии с репрезентациями пяти базисных фреймов - предметного, акционального, посессивного, идентификационного, компаративного.

Предметный фрейм “Spiel” («игра») и “Kampf” («борьба») описывается с помощью трех бытийных (пропозициональных) схем - квантитативной, квалитативной, локативной. Пропозициональные схемы темпоральная и способа бытия в представленных контекстах не выявлены. Количественное измерение концептов “Spiel” («игра») и “Kampf” («борьба») определяется в соответствии с лексикографическим описанием, оппозиция форм единственного и множественного числа зафиксирована в словарях и подтверждается в корпусе выбранных для анализа текстов и языковых контекстов. В квалитативном, качественном, отношении “Spiel” («игра») и “Kampf” («борьба») оцениваются нейтрально. Локативные характеристики представлены у концепта "Spiel".

Акциональные фреймы концептов “Spiel” («игра») и "Kampf” («борьба») в исследованных языковых контекстах выявлены с помощью двух акциональных (пропозициональных) схем - контактного действия и каузации. Примеры пропозициональных схем состоя- 
ния/процесса не выявлены. В схемах контактного действия "Spiel” («игра») и “Kampf” («борьба») выступают в двух ролях — объекта и медиатива. В качестве субъектов "Spiel” («игра») и “Kampf” («борьба») выступают базовые концепты силы “Kraft” и "Macht”.

Посессивный и компаративный фреймы концептов “Spiel” («игра») и “Kampf” («борьба») в исследованных контекстах не представлены.

Идентификационный фрейм концептов “Spiel” («игра») и “Kampf” («борьба») объединяет идентификационные схемы классификации (отношения «род - вид», неопределенности) и не представлен пропозициональными схемами персонификации и характеризации. Ханна Арендт определяет борьбу в качестве родового признака политики - как «борьбу за власть» (ради власти). Борьба в ее представлении может выступать родовым признаком жизни. Мишель Фуко определял власть через родовой признак — как игру, которая в непрерывных столкновениях и противостояниях (Kämpfen) преобразует, усиливает и извращает соотношения сил. Борьба (Kampf), по мнению Фуко, выступает средством игры (Spiel), в определенном смысле - ее формой.

\section{Список источников}

1. Жаботинская С. А. Имя как текст: концептуальная сеть лексического значения (анализ имени эмоции) // Когниция, коммуникация, дискурс. - 2013. - № 6. - С. 47-76.

2. Степанов В. Н. Смысл силы : очерки немецкой философской традиции. - Ярославль : Междунар. акад. бизнеса и новых технологий (МУБиНТ), 2016. - 160 с.

3. Arendt Hannah. Macht und Gewalt. - München : Piper, 1970. — 106 S.

4. Foucault Michel. Der Wille zum Wissen. Sexualität und Wahrheit. - Frankfurt am Main : Suhrkamp, 1983. - 189 S.

5. Forst Rainer. Normativität und Macht. Zur Analyse sozialer Rechtfertigungsordnungen. 1. Aufl. — Frankfurt am Main : Suhrkamp, 2015. — 254 S.

6. Habermas Jürgen. Der philosophische Diskurs der Moderne : zwölf Vorlesungen. — 1. Aufl. — Frankfurt am Main : Suhrkamp, 1985. — 449 S.

7. Heidegger Martin. Nietzsche : in 2 Bd. - Pfullingen : Neske, 1961. - Bd. 1. - 661 S. ; Bd. 2. $-492 \mathrm{~S}$.

8. Jenisch Daniel. Philosophisch-kritische Vergleichung und Würdigung von vierzehn ältern und neuern Sprachen Europens, namentlich: Der griechischen, lateinischen, italienischen, spanischen, portugiesischen, französischen, englischen, deutschen, holländischen, dänischen, schwedischen, polnischen, russischen, litthauischen. - Berlin : Maurer, 1796. - $503 \mathrm{~S}$.

9. Kant Immanuel. Kritik der reinen Vernunft : in 2 Bd. / Hrsg. Von Wilhelm Weischedel. Frankfurt am Mein : Suhrkamp, 1974. — Bd. 1. - 348 S. ; Bd. 2. - 724 S.

10. Luhmann Niklas. Macht. - 4. Aufl. — Konstanz : UVK Verl.-Ges. ; München : UVK/Lucius, 2012. - $177 \mathrm{~S}$.

11. Mills Charles Wright. The Power Elite. — New York : Oxford University Press, 1956. — 423 p.

12. Weber Max. Die protestantische Ethik und der Geist des Kapitalismus. - Köln : Anaconda, 2009. - $286 \mathrm{~S}$.

\section{References}

1. Zhabotinskaya S. A. A Name as a Text: The Conceptual Network of Lexical meaning (Analysis of the name of emotion). Kognicia, kommunicacia, diskurs [Cognition, Communication. Discourse]. 2013, no. 6, pp. 47-76. (In Russian).

2. Stepanov V. N. Smysl sily: ocherki nemetskoi filosofskoi tradicii [The Essence of Power: Studies in the German Philosophic Tradition]. Yaroslavl, International Academy of Business and New technologies ( MUBiNT), 2016, 160 p. (In Russian).

3. Arendt Hannah. Macht und Gewalt. München, Piper, 1970, 106 S.

4. Foucault Michel. Der Wille zum Wissen. Sexualität und Wahrheit. Frankfurt am Main, Suhrkamp, 1983, 189 S. 
5. Forst Rainer. Normativität und Macht. Zur Analyse sozialer Rechtfertigungsordnungen. 1. Aufl. Frankfurt am Main, Suhrkamp, 2015, 254 S.

6. Habermas Jürgen. Der philosophische Diskurs der Moderne. Zwölf Vorlesungen. 1. Aufl. Frankfurt am Main, Suhrkamp, 1985, 449 S.

7. Heidegger Martin. Nietzsche : in 2 Bd. Pfullingen, Neske, 1961. Bd. 1, 661 S. ; Bd. 2, 492 S.

8. Jenisch Daniel. Philosophisch-kritische Vergleichung und Würdigung von vierzehn ältern und neuern Sprachen Europens, namentlich: Der griechischen, lateinischen, italienischen, spanischen, portugiesischen, französischen, englischen, deutschen, holländischen, dänischen, schwedischen, polnischen, russischen, litthauischen. Berlin, Maurer, 1796, 503 S.

9. Kant Immanuel. Kritik der reinen Vernunft. In 2 Bd. / Hrsg. Von Wilhelm Weischedel. Frankfurt am Mein, Suhrkamp, 1974, Bd. 1, 348 S. ; Bd. 2, 724 S.

10. Luhmann Niklas. Macht. 4. Aufl. Konstanz, UVK Verl.-Ges., München, UVK/Lucius, 2012, 177 S.

11. Mills Charles Wright. The Power Elite. New York : Oxford University Press, 1956, 423 p.

12. Weber Max. Die protestantische Ethik und der Geist des Kapitalismus. Köln, Anaconda, $2009,286 \mathrm{~S}$.

\section{Информация об авторе}

Степанов Валентин Николаевич - доктор филологических наук, профессор, заслуженный работник высшей школы РФ, почетный работник высшего профессионального образования Российской Федерации, проректор по управлению знаниями Международной академии бизнеса и новых технологий (МУБиНТ). Почтовый адрес: 150003, г. Ярославль, ул. Советская, д. 80, каб. 316. Тел.: 89159699060.

\section{Information about the author}

Stepanov, Valentin - Ph. D. (Doctor of Philology), Professor, Merited Educator of Tertiary Education of the Russian Federation, Deputy Rector for Knowledge Management, International University of Business and New Technologies (MUBiNT). Postal address: 80 Sovetskaya St., Office 316, 150003, Yaroslavl, Russia. Tel.: 89159699060.

Статья поступила в редакцию 19.04.2021;

одобрена после рецензирования 21.04.2021;

принята к публикации 22.04.2021.

Submitted 19.04.2021;

approved after reviewing 21.04.2021;

accepted for publication 22.04.2021. 
РАЗДЕЛ II

\title{
СЕМАНТИКА ЗНАКОВ В ДИСКУРСЕ: КОГНИТИВНЫЙ АСПЕКТ
}

Иностранные языки в высшей школе. 2021. № 2 (57). С. 34-41.

Foreign Languages in Tertiary Education. 2021;2(57):34-41.

Научная статья

УДК 811.11

DOI: $10.37724 /$ RSU.2021.57.2.003

\section{Метафорическая креативность в дорожных знаках}

\author{
Екатерина Евгеньевна Голубкова ${ }^{1}$, \\ Мария Павловна Таймур ${ }^{2}$ \\ 1,2 Московский государственный лингвистический университет, Москва, Россия \\ ${ }^{1}$ katemg@yandex.ru \\ 2 mariataymour@gmail.com
}

Аннотация. В статье проводится анализ феномена креативности в дорожных знаках, содержащих мономодальные визуальные, мультимодальные вербально-визуальные или смешанные метафоры. Актуальность исследования механизма возникновения феномена смешанной метафоры на материале изображений дорожных знаков, в которых наблюдаются креативные целенаправленные девиации от прототипа весьма высока, поскольку уровень возникающего когнитивного диссонанса у водителей транспортных средств и пешеходов при взаимодействии с дорожными знаками напрямую влияет на уровень безопасности и комфортности дорожного движения и в идеале должен быть приближен к нулю. В задачи исследования входит поэтапный анализ проблемы формирования смысла подобных метафор и изучение факторов, которые могут способствовать успешности расшифровки их смысла. Целью работы является изучение когнитивных и прагматических особенностей функционирования метафоры в дорожных знаках. Результаты исследования показали, что когнитивный диссонанс, возникающий у реципиента при инференции значения преобразованных знаков, может быть уравновешен действием механизма когнитивного резонанса. Диссонанс полезен при использовании знаков в качестве арт-объектов / рекламы / выражения юмора / критики и недопустим в контексте реальной ситуации дорожного движения, так как это может приводить к дорожным происшествиям и другим нежелательным последствиям.

Ключевые слова: метафора, смешанная метафора, когнитивный диссонанс, когнитивный резонанс, лингвистическая креативность.

Для цитирования: Голубкова Е. Е., Таймур М. П. Метафорическая креативность в дорожных знаках // Иностранные языки в высшей школе. 2021. № 2 (57). C. 34-41. DOI: 10.37724/RSU.2021.57.2.003.

Original article

\section{Metaphorical Creativity in Road Signs}

\author{
Ekaterina E. Golubkova ${ }^{1}$, Maria P. Taymour ${ }^{2}$ \\ ${ }^{1,2}$ Moscow State Linguistic University, Moscow, Russia \\ ${ }^{1}$ katemg@yandex.ru \\ 2 mariataymour@gmail.com
}

\begin{abstract}
The article analyzes the phenomenon of creativity in road signs as possible carriers of monomodal visual, multimodal verbal-visual, or mixed metaphors. The relevance of the mechanism of the emergence of the phenomenon of mixed metaphor on the material of images of road signs, in which creative purposeful deviations from the prototype are observed, is very high, since the level of development of cognitive
\end{abstract}

(C) Голубкова Е. Е., Таймур М. П., 2021 
purposeful deviations from the prototype are observed, is very high, since the level of development of cognitive dissonance in vehicle drivers and pedestrians when interacting with road signs directly affects the level of safety and quality of road traffic, and ideally should be close to zero. The tasks of the study include similar metaresearch and factors that can be successful in deciphering the meaning of such signs. The aim of the research is to study cognitive and pragmatic functions of metaphors in road signs. The results of the study showed that the cognitive dissonance that provides the recipient with the meaning of the transformed signs during inference, can be balanced by the mechanism of cognitive resonance. Dissonance is useful when using signs as art objects / advertising / humor / criticism, while it is unacceptable in the context of a real traffic situation, as it can lead to traffic accidents and other undesirable consequences.

Keywords: metaphor, mixed metaphor, the cognitive dissonance, linguistic creativity.

For citation: Golubkova E. E., Taymour M. P. Metaphorical Creativity in Road Signs. Foreign Languages in Tertiary Education. 2021;2(57):34-41. (In Russ.). DOI: 10.37724/RSU.2021.57.2.003.

В современном мире, характеризующемся динамизмом, ускорением темпа жизни, быстрым развитием разнообразных форм коммуникации и, как следствие, многоликостью культурной динамики общества [Баркер 2001], различного рода символы и знаки, например эмотиконы, становятся особенно популярным средством общения. Это объясняется необходимостью доносить до реципиента нужную информацию во все более сжатой и лаконичной форме, что отражает такую глобальную характерную черту современной коммуникации, как пространственно-временная компрессия [Березовская, Кирьянова, 2009 ; Манерко, 2018].

Метафора, являющаяся одним из алгоритмов мышления, сама по себе может рассматриваться как пример когнитивного механизма компрессии информации. После выхода в свет работы Джонсона и Лакоффа «Метафоры, которыми мы живем» [Lakoff, Johnson, 1980] стало очевидно, что метафоры пронизывают нашу жизнь, являясь весьма популярным и компактным средством выражения мысли в любых повседневных ситуациях общения. В так называемой смешанной метафоре, представляющей собой «несколько метафор с различной когнитивной основой в непосредственной контекстуальной близости» ${ }^{1}$ [Kimmel, 2009, p. 97] (cp. rocket surgery), компрессия информации происходит с особой интенсивностью. По этой причине для инференции значения подобных выражений иногда требуется высокий уровень фоновых знаний, владения языком и лингвистической креативности, что может вызывать у реципиента ментальное напряжение, или так называемый когнитивный диссонанс, приводящий к срыву коммуникации (см. подробнее исследования на примерах мультимодальных и мономодальных смешанных метафор в английском языке [Голубкова, Таймур, 2019 ; Таймур, 2019, 2020]). Наблюдаемая тенденция к визуализации информации, в частности при преподавании различных наук и языков, вовлекает в «зону смешения» мультимодальный материал: изображения, мемы, смайлы, гифы, карикатуры, граффити и пр. Подача информации в креолизованной форме подразумевает как минимум взаимодействие двух семиотических систем - вербальной и визуальной, с одной стороны, предъявляя повышенные требования к интерпретатору, с другой - упрощая задачу расшифровки «послания» благодаря возможности его изучения, не лимитированного во времени. Иными словами, креолизованный текст можно долго разглядывать и анализировать в отличие, скажем, от мимолетного высказывания в устном дискурсе. Одним из нетривиальных проявлений креативности в мультимодальной среде является «игра» с изображением знаков дорожного движения, которые также можно рассматривать как креолизованные послания реципиенту, построенные на основе матрицы общепринятых обозначений.

Напомним, что дорожные знаки, встречающиеся во всех странах мира для регулирования и упорядочения действий участников дорожного движения, подразделяются: на предупреждающие, запрещающие, предписывающие, информационные знаки; знаки приоритета, особых предписаний, сервиса и дополнительной информации. Дорожные знаки имеют три значимых базовых визуальных элемента: форму, цвет и, как правило, изображение

\footnotetext{
${ }^{1}$ Здесь и далее перевод наш. - E. Г., M. T.
} 
предмета или человека. Очень часто значение знака зависит от вербальной информации, расположенной в знаке, над/под знаком, что превращает его в креолизованный минитекст. Кроме того, важную прагматическую роль имеет конкретное место расположения знака. Дорожные знаки призваны своевременно информировать участника движения о ситуации на данном участке дороги и соответственно должны быть предельно идентичны, лаконичны, понятны (хотя бы интуитивно) и общеприняты на международном уровне. То есть можно утверждать, что практически все знаки дорожного движения - это определенные универсальные метафоры или метонимии (ср. знак «кирпич»), анализируемые в настоящем исследовании либо как мономодальные визуальные метафоры (например, во всех странах мира красный круг с белой горизонтальной полосой внутри обозначает «въезд запрещен»), либо как мультимодальные вербально-визуальные метафоры (например, красный шестиугольник с надписью STOP означает «движение без остановки запрещено»).

Материалом исследования послужили 100 дорожных знаков, установленных на дорогах Российской Федерации и за рубежом, отобранных методом сплошной выборки в открытых интернет-ресурсах и визуальном корпусе Google Image. Для решения поставленных задач мы будем опираться на лингвопрагматический анализ и метод дискурсивного анализа. Возможное практическое применение результатов исследования заключается в том, что выявление специфики функционирования феномена смешанной метафоры в контексте международных дорожных знаков будет способствовать повышению уровня успешности оперативной инференции участниками дорожного движения значения подобных единиц дискурса и соответственно снижению вероятности их неверного декодирования и провоцирования аварийных ситуаций.

Как и вербальные смешанные метафоры, которые часто являются спонтанным выражением креативности автора высказывания (например, Nothing to shake home about) или случайной оговоркой (например, I have it on the tip of my hand), дорожные знаки могут быть весьма нестандартными (рис. 1), не всегда ограниченными доменом «дорожное движение» или свидетельствовать об ошибочных действиях дорожных служб (рис. 2).
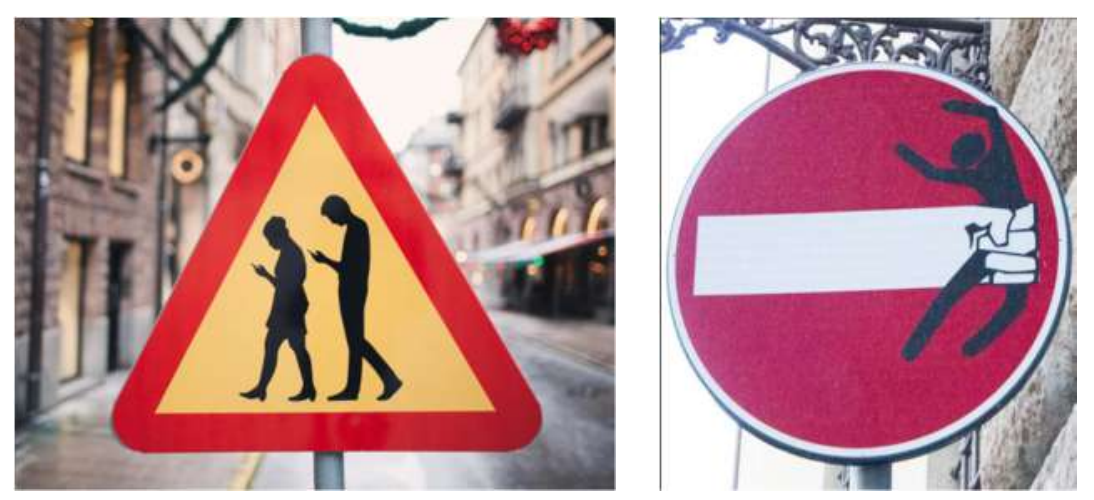

Рис. 1. Креативные дорожные знаки
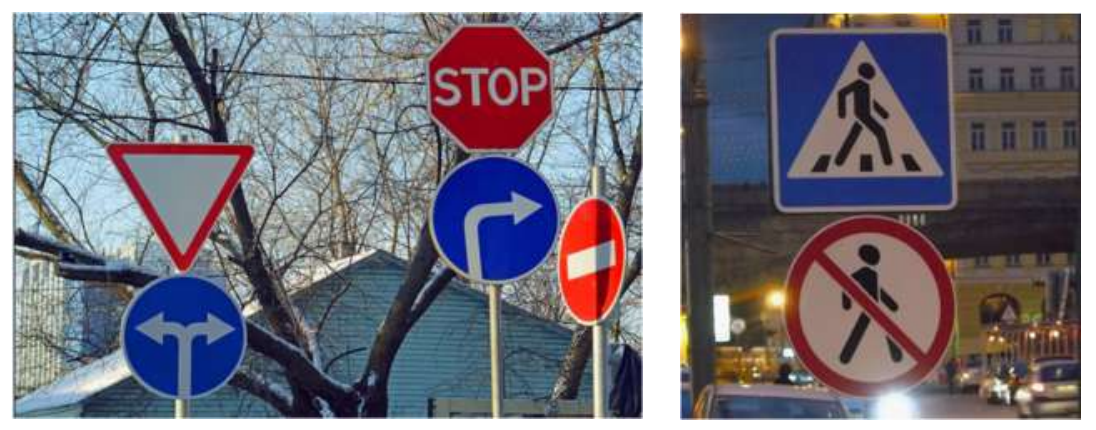

Рис. 2. Ошибочное расположение дорожных знаков 
Лингвистическая составляющая дорожных знаков (как их лексическое, так и грамматическое наполнение) играет важную роль при инференции значения знака реципиентом. Чарльз Форсвиль обозначает данный феномен "micro-vocabulary and micro-grammar" «микролексикой и микрограмматикой», что вполне точно описывает особенности их функционирования в этом весьма специфичном микродискурсе. Тем не менее в случае мультимодальных дорожных знаков, когда речь идет о лексическом компоненте, необходимо использовать понятие «лексика» с осторожностью ("use the concept of "vocabulary" with great caution”) [Forceville, 2019, p. 104].

Креативность в дорожных знаках с когнитивной точки зрения может восприниматься неоднозначно: если подобные знаки создаются с целью рекламы или как основа для артобъектов, то их основной задачей является привлечение внимания и запоминаемость для реципиента благодаря необычности изображения. Поскольку в форме и цвете знака закодирована вполне определенная информация, понятная всем реципиентам, знакомым хотя бы на базовом уровне с правилами дорожного движения (например, красный треугольник всегда означает предупреждение), существует возможность использовать знаки как мультимодальные метафоры в юмористических целях, для прагматического воздействия на окружающих, убеждения в необходимости предпринять некоторые действия, не относящиеся к поведению на дороге (рис. 3). В подобном случае определенное ментальное напряжение или когнитивный диссонанс (термин Фестингера, используемый как в психологии, так и в лингвистике [Festinger, 1957]) может быть полезен, провоцируя лучшее усвоение и запоминание идей адресатом. К таким «разновидностям» официальных знаков, разрешающих пешеходам переходить улицу, относятся, например, варианты с ежиком, уткой в сопровождении утят, черепахой, ползущим человеком.
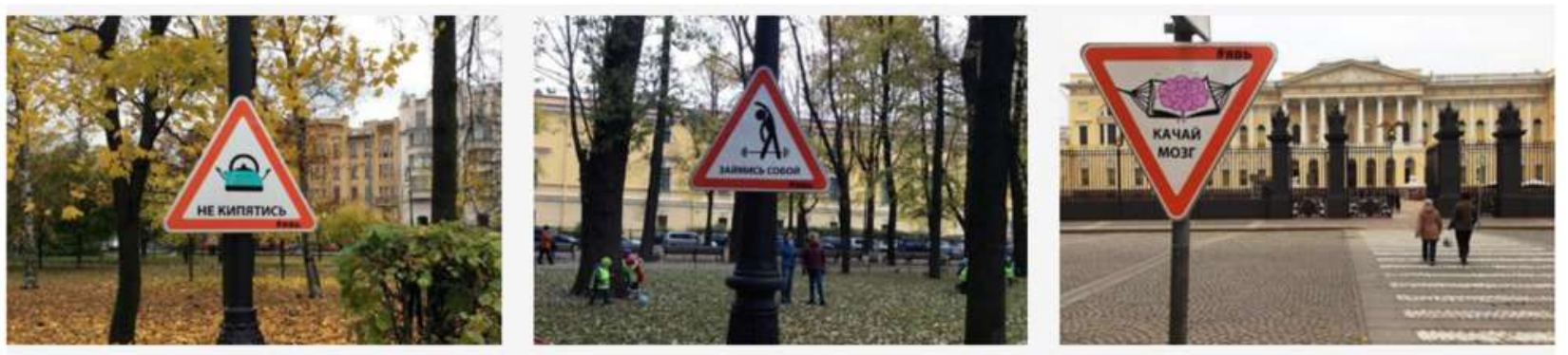

Puc. 3. Креативные мультимодальные дорожные знаки

Более радикальные варианты преобразования знаков приводят к более сложным смысловым преобразованиям содержания. Термин «смешанная метафора» для подобных мультимодальных метафор некоторыми учеными тем не менее не используется. Например, Ч. Форсвиль предлагает называть подобные явления "multiple source domain metaphor" «метафора с доменами из различных источников» [Forceville, 2016, p. 18]. Мы, однако, считаем, что употребление термина «мультимодальная смешанная метафора» в подобных случаях правомерно, но лишь в тех случаях, когда соблюдаются три основных условия: 1) использование двух (или более) исходных доменов при наличии единого целевого домена в ограниченном объеме дискурса; 2) наличие невербального компонента; 3) возникновение повышенного уровня когнитивного диссонанса у реципиента [см. подробнее: Голубкова, Таймур, 2020]. Именно поэтому дорожные знаки на рисунке 3 могут быть признаны мультимодальными смешанными метафорами. Тем не менее уровень возникающего в подобных случаях когнитивного диссонанса должен быть уравновешен действием механизма когнитивного резонанса, обусловливающего актуальность когнитивно-речевого образа и согласие участников коммуникативного акта (в том числе совместное принятие дальнейших решений) [Sperber, Mercier, 2012]. Поскольку когнитивный резонанс может быть охарактеризо- 
ван как взаимное усиление и дополнение концептуальных проекций интерсубъективного и предметного содержания интеракции [Попова, 2019], он является одним из основных когнитивных механизмов, влияющих на успешность коммуникации, в особенности в формате инференции смыслов дорожных знаков. Если креативно преобразованный знак вписывается в знакомый контекст существования языкового сообщества, то резонанс способен сбалансировать диссонанс и обеспечить верную однозначную интерпретацию дорожного послания.

Так, зачастую с помощью креативных дорожных знаков их авторами высмеивается существующая неудовлетворительная ситуация на дорогах. Например, на Урале, где качество дорожных покрытий часто оставляет желать лучшего, несколько лет назад появились знаки, красноречиво на это указывающие (рис. 4). В подобных случаях метафорические изображения являются способом самовыражения и критики. Здесь так же, как и в большинстве случаев репрезентации идей с помощью дорожных знаков, отмечается действие когнитивного механизма компрессии информации со стороны автора и механизма декомпрессии информации со стороны адресата. Несмотря на отсутствие в некоторых случаях лингвистической составляющей, можно предполагать, что в результате декомпрессии информации у реципиента автоматически синтезируется вербальная составляющая в результате несложных когнитивных усилий (например, на рисунке 4 это может быть опасность, плохая дорога, неровности и т. д.). Необходимо отметить, что органы власти планировали оштрафовать высококреативных создателей данных знаков, а сами знаки были оперативно демонтированы дорожными службами, что свидетельствует об удачном способе выражения идей автора (авторов) и достигнутом прагматическом эффекте.
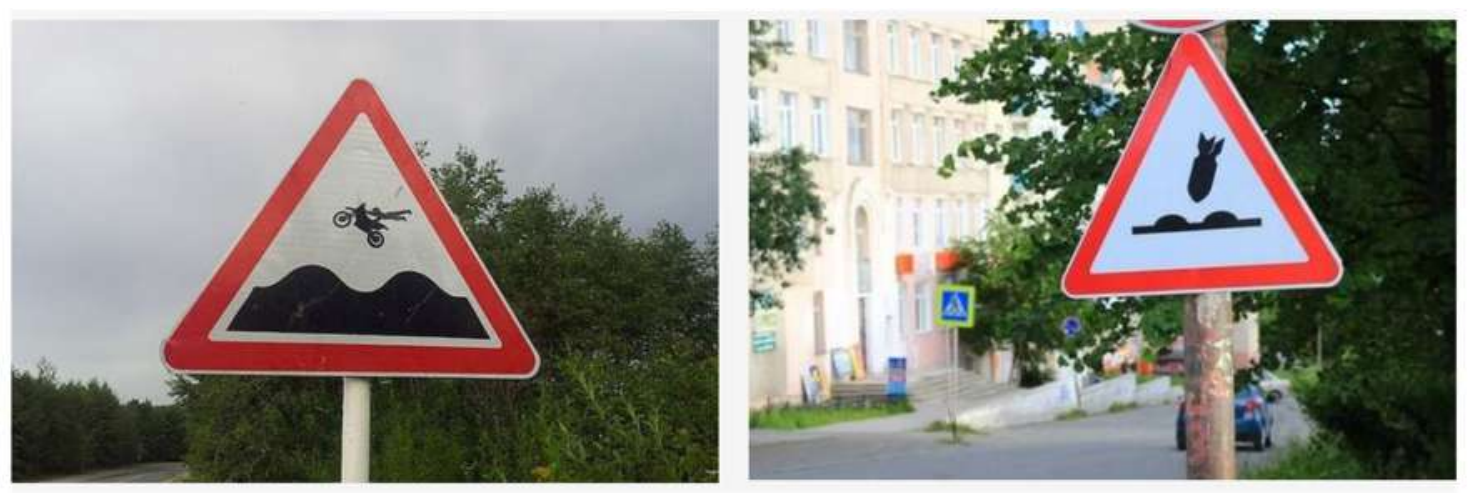

Puc. 4. Креативные дорожные знаки

Иногда, однако, дорожный знак, призванный помочь водителю независимо от того, носителем какого языка он/она является, оперативно оценить ситуацию на дороге, может ввести его/ее в заблуждение и вызвать повышенное ментальное напряжение, упомянутый выше когнитивный диссонанс. Если в процессе создания креативного элемента дискурса (мономодального либо мультимодального) результатом соединения составляющих его единиц является синтез, это способствует верной и оперативной инференции значения реципиентом, тогда как если присутствует столкновение или конфронтация элементов, то это обычно вызывает определенное когнитивное напряжение и часто сопровождается созданием юмористического эффекта. В случае, когда дорожные знаки используются вне дорожных ситуаций (рис. 3), это вполне допустимо, однако, если размещение подобных знаков происходит на проезжей части или вблизи нее, это может быть рассмотрено как прямая стимуляция аварийных ситуаций. Например, на рисунке 5 изображены падающие силуэты людей, а лингвистическая составляющая "Caution. Falling People" (Осторожно, падающие люди) не помогает оперативно разобраться в ситуации - либо впереди обрыв и возможно падение, либо возможно падение пешеходов на проезжую часть. На самом деле знак обо- 
значает присутствие впереди аттракциона "Bungee jumping" - прыжки с моста с канатом. Подобные мультимодальные метафоры могут быть признаны смешанными, но их присутствие в данном контексте крайне нежелательно.

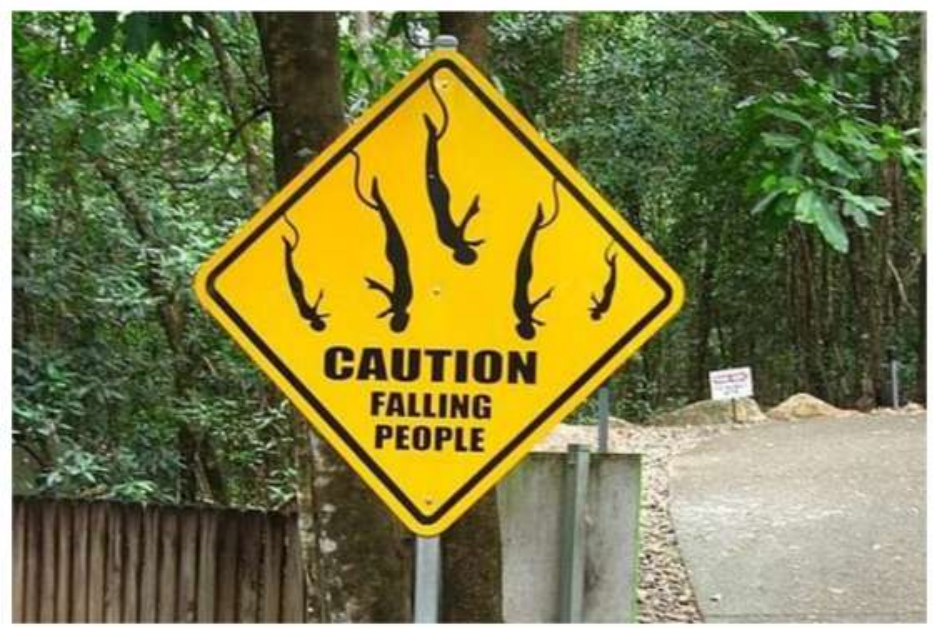

Puc. 5. Дорожный знак "Caution Falling People” в США

Таким образом, целенаправленное либо случайное провоцирование когнитивного диссонанса у реципиента в процессе декодирования значения творчески модифицированных дорожных знаков, уравновешенного необходимым для верной инференции уровнем когнитивного резонанса, допустимо и даже желательно при использовании данных знаков вне контекста дорожного движения в качестве арт-объектов, рекламы, шутки, критики и т. д. Однако даже невысокая степень повышения уровня когнитивного диссонанса недопустима, когда дорожные знаки используются в реальной ситуации дорожного движения, поскольку это может приводить к авариям и другим нежелательным последствиям.

Перспективы дальнейшего исследования настоящей проблемы видятся в изучении и использовании психофизиологических показателей для изучения когнитивных процессов при восприятии реципиентом различных дорожных знаков, в особенности метода eye-tracking. Отслеживая движения глаз потребителя информации, можно получить ценную информацию о восприятии текста в режиме реального времени (Rayner et al., 2006), что может быть использовано для достижения более детального понимания когнитивных процессов, проходящих во время интерпретации смысла, в том числе мультимодальных единиц. Известно, что существует тесная связь между когнитивными усилиями и продолжительностью фиксации глаза на определенных лексических единицах, что представляется нам одним из наиболее актуальных направлений дальнейших исследований данной проблемы.

\section{Список источников}

1. Баркер К. Глобализация и культурная идентичность // Контексты современности : хрестоматия. - Ч. 2. - Казань : Казан. гос. ун-т, 2001. - С. 124-128.

2. Березовская О. М., Кирьянова Л. Г. Тенденции этноязыковых процессов в условиях глобализации современного общества // Известия Томского политехнического университета. - 2009. Т. 315, № 6. - С. 144-148.

3. Голубкова Е. Е., Таймур М. П. Факторы преодоления когнитивного диссонанса в смешанных метафорах (на материале английского языка) // Когнитивные исследования языка. — 2019. № 36. - C. 147-154.

4. Голубкова Е. Е., Таймур М. П. Вербально-графическая метафора: рецепты успешного приготовления // Когнитивные исследования языка. — 2020. — № 2 (41). — С. 386-391. 
5. Манерко Л. А. Языковая личность в когнитивных и дискурсивных исследованиях // Когнитивные исследования языка. - 2018. - № 32. - С. 353-361.

6. Попова Г. Е. Релевантность речевой интеракции: аспектуальная и жанровая типология : моногр. - Пятигорск : Изд-во Пятигорск. гос. ун-та, 2019. - 368 с.

7. Таймур М. П. Когнитивный диссонанс в смешанных метафорах на английском языке // Вестник Московского государственного лингвистического университета. Гуманитарные науки. 2019. — № 13 (829). — С. 84-95.

8. Таймур М. П. Когнитивные факторы неудачности смешения метафор в английском языке // Когнитивные исследования языка. — 2020. — № 3 (42). — С. 234-238.

9. Festinger L. A theory of cognitive dissonance. - Stanford : University Press, 1957. - $291 \mathrm{p}$.

10. Forceville C. Visual and multimodal metaphor in film: charting the field // Embodied Metaphors in Film, Television and Video games: Cognitive Approaches / ed. K. Falenbrach. — London : Routledge, 2016. - Pp. 17-32.

11. Forceville C. Reflections on the creative use of traffic signs' "micro-language" // Image and metaphor in the new century / eds. A. Benedek, K. Nyíri. Budapest : Hungarian Academy of Sciences Budapest University of Technology and Economics, 2019. - Pp. 103-117.

12. Kimmel M. Why We Mix Metaphors (and Mix Them Well) // Journal of Pragmatics. University of Vienna. - 2009. - N 42. - Pp. 97-115.

13. Lakoff G., Johnson M. Metaphors We Live By. - Chicago : University of Chicago Press, 1980. - $252 \mathrm{p}$.

14. Rayner K., Chace K. H., Slattery T. J., Ashby J. Eye movements as reflections of comprehension processes in reading // Scientific Studies of Reading. — 2006. - N 10 (3). - Pp. 241-255.

15. Speber D., Mercier H. Reasoning as a social competence // Collective wisdom: Principles and mechanisms. - 2012. - Pp. 368-392.

\section{References}

1. Barker K. Globalization and Cultural Identity. Konteksty sovremennosti. Khrestomatiya [Modern context. Reader]. Kazan, 2001, pp. 124-128. (In Russian).

2. Berezovskaya O. M., Kirianova L. G. Trends in ethno-linguistic processes in the context of globalization of modern society. Izvestiya Tomskogo politekhnicheskogo universiteta [Bulletin of the Tomsk Polytechnic University]. 2009, vol. 315, no. 6, pp. 144-148. (In Russian).

3. Golubkova E. E., Taymour M. P. Faktory preodoleniya kognitivnogo dissonansa v smeshannykh metaforakh (na materiale angliyskogo yazyka). Kognitivnyye issledovaniya yazyka [Cognitive Studies of Language]. 2019, no. 36, pp. 147-154. (In Russian).

4. Golubkova E. E., Taymour M. P. Verbal-visual metaphors: the recipe of successful cooking. Kognitivnyye issledovaniya yazyka [Cognitive Studies of Language]. 2020, no. 2 (41), pp. 386-391. (In Russian).

5. Manerko L. A. Language Personality in Cognitive and Discursive Research. Kognitivnyye issledovaniya yazyka [Cognitive Studies of Language]. 2018, no. 32, pp. 353-361. (In Russian).

6. Popova G. E. Relevantnost rechevoy interaktsii: aspektualnaya i zhanrovaya tipologiya [Relevance of Speech Interaction: Aspectual and Genre Typology]. Pyatigorsk, PGU Publ., 2019, 368 p. (In Russian).

7. Taymour M. P. Cognitive Dissonance in Mixed Metaphors and Malaphors in English. Vestnik Moskovskogo gosudarstvennogo lingvisticheskogo universiteta. Gumanitarnyye nauki [Vestnik of Moscow State Linguistic University. Humanities]. 2019, no. 13 (829), pp. 84-95. (In Russian).

8. Taymour M. P. Cognitive Factors of Failures in Mixing Metaphors in the English Language. Kognitivnyye issledovaniya yazyka [Cognitive Studies of Language]. 2020, no. 3 (42), pp. 234-238. (In Russian).

9. Festinger L. A theory of cognitive dissonance. USA, Stanford University Press, 1957, $291 \mathrm{p}$.

10. Forceville C. Visual and multimodal metaphor in film: charting the field. (Ed.) Falenbrach K. Embodied Metaphors in Film, Television and Video games: Cognitive Approaches. London, Routledge, 2016, pp. 17-32.

11. Forceville C. Reflections on the creative use of traffic signs' "micro-language". (Eds.) A. Benedek, K. Nyíri. Image and metaphor in the new century. Budapest, Hungarian Academy of Sciences Budapest University of Technology and Economics, 2019, pp. 103-117. 
12. Kimmel M. Why We Mix Metaphors (and Mix Them Well). Journal of Pragmatics. University of Vienna. 2009, no. 42, pp. 97-115.

13. Lakoff G., Johnson M. Metaphors We Live By. Chicago, University of Chicago Press, 1980, 252 p.

14. Rayner K., Chace K. H., Slattery T. J., Ashby J. Eye movements as reflections of comprehension processes in reading. Scientific Studies of Reading. 2006, no. 10 (3), pp. 241-255.

15. Speber D., Mercier H. Reasoning as a social competence. Collective wisdom: Principles and mechanisms. 2012, pp. 368-392.

\section{Сведения об авторе}

Голубкова Екатерина Евгеньевна - доктор филологических наук, профессор, профессор кафедры лексикологии факультета английского языка ФГБОУ ВО «Московский государственный лингвистический университет». Почтовый адрес: 119034, г. Москва, ул. Остоженка, д. 38. Тел.: +79162268857 .

Таймур Мария Павловна - старший преподаватель кафедры лингвистики и профессиональной коммуникации в области гуманитарных и прикладных наук ИГПН ФГБОУ ВО «Московский государственный лингвистический университет». Почтовый адрес: 119034, г. Москва, ул. Остоженка, д. 38. Тел.: +79104873156.

\section{Information about the author}

Golubkova, Ekaterina - doctor of philology, professor, professor of the department of English lexicology, the Faculty of the English language, Moscow State Linguistic University. 119034, Moscow, Ostozhenka, 38, Tel.: +79162268857.

Taymour, Maria - senior lecturer of the department of linguistics and professional communication in the humanities and applied sciences, Moscow State Linguistic University. 119034, Moscow, Ostozhenka, 38, Tel.: +79104873156.

Статья поступила в редакичи 14.04.2021;

одобрена после речензирования 20.04.2021;

принята к публикации 22.04.2021

Submitted 14.04.2021;

approved after reviewing 20.04.2021;

accepted for publication 22.04.2021 
Иностранные языки в высшей школе. 2021. № 2 (57). С. 42-56.

Foreign Languages in Tertiary Education. 2021;2(57):42-56.

Научная статья

УДК 81'42

DOI: $10.37724 /$ RSU.2021.57.2.004

\section{Ресемантизация дискурсивных слов в современной русско- и англоязычной поэзии 1}

\section{Екатерина Васильевна Захаркив}

Институт языкознания РАН, Москва, Россия

zakate90@gmail.com

Аннотация. В статье рассматривается прием ресемантизации дискурсивных слов (ДС) на материале поэтического дискурса. Ресемантизация определяется как авторский прием, реализуемый посредством модификации лексического значения и функциональной нагрузки дискурсивных единиц, а также в некоторых случаях — снятия с ДС свойственной им стереотипности и осмысления их в качестве полнозначных единиц. Новизна исследования обусловлена недостаточной изученностью прагматического аспекта поэтического дискурса на фоне разработанности семантики и синтактики поэтического текста. Кроме того, актуальность анализа авторских лингвокреативных модификаций ДС основана на повышенном внимании современных поэтов к прагматике поэтического текста как высказывания в результате активизации канала передачи сообщения, обретающего статус интерфейса в интернет-пространстве. В ходе анализа мы выявили основные разновидности экспериментальных модификаций в современном поэтическом дискурсе: ресемантизация ДС на основе паронимической аттракции, соположение ДС по принципу семантического противопоставления и фрагментация ДС. Анализ ресемантизации ДС позволил выявить направленность современной поэзии на активизацию прагматического «измерения» языка, семантическую аномальность и неоднозначность, автокоммуникативность и перефокусирование значений. Таким образом, рассмотренный в статье прием ресемантизации характеризует поле взаимодействия поэтического дискурса с обыденным, которое выражается в активном включении прагматических единиц и одновременном разрушении клишированности обыденного дискурса, и сопровождается метаязыковой рефлексией.

Ключевые слова: ресемантизация, дискурсивные слова, дефразеологизация, стереотипность, деавтоматизация, перефокусирование, поэтический дискурс, метаязыковая рефлексия, лингвокреативная модификация.

Для цитирования: Захаркив Е. В. Ресемантизация дискурсивных слов в современной русскои англоязычной поэзии // Иностранные языки в высшей школе. 2021. № 2 (57). С. 42-56. DOI: 10.37724/ RSU.2021.57.2.004.

Original article

\section{Resemantization of Discourse Markers in Contemporary Russo- and Anglophone Poetry}

\section{Ekaterina V. Zakharkiv}

Institute of Linguistics, the Russian Academy of Sciences, Moscow, Russia zakate90@gmail.com

Abstract. The article discusses the method of resemantization of discourse markers (DM) on the basis of Russian and English poetic discourse. Resemantization is defined as a special authorial technique, implemented by modifying the lexical meaning and functional load of the unit, and also, in some cases,

${ }^{1}$ Исследование выполнено в Институте языкознания РАН при финансовой поддержке гранта Российского научного фонда (проект №19-18-00040).

(C) Захаркив Е. В., 2021 
removing their inherent stereotypes from DM and interpreting them as the semantic units. The novelty of the research is due to the insufficient study of the pragmatic aspect of poetic discourse against the background of the developed semantics and syntactics of the poetic text. In addition, the relevance of the analysis of the authorial linguocreative modifications of the DM is based on the increased attention of modern poets to the pragmatics of the poetic text as an utterance as a result of the activation of the message transmission channel, which acquires the status of an interface in the Internet. In the course of the analysis, we identified the main varieties of experimental modifications based on the modern poetic discourse: DM resemantization based on paronymic attraction; DM matching according to the principle of semantic opposition; DM fragmentation. The analysis of the DM resemantization made it possible to reveal the focus of modern poetry on the activation of the pragmatic "dimension" of the language, semantic anomaly and ambiguity, autocommunication and refocusing of meanings. Thus, the method of resemantization considered in the article characterizes the field of interaction of poetic discourse with the ordinary, expressed in the active inclusion of pragmatic units and the simultaneous destruction of the cliché of everyday discourse, accompanied by metalanguage reflection.

Keywords: resemantization, discursive words, defraseologization, stereotype, deautomatization, refocusing, poetic discourse, metalanguage reflection, linguocreative modification.

For citation: Zakharkiv E. V. Resemantization of Discourse Markers in Contemporary Russo- and Anglophone Poetry. Foreign Languages in Tertiary Education. 2021;2(57):42-56. (In Russ.). DOI: 10.37724/ RSU.2021.57.2.004.

Изучение «прагматического измерения языка» (в терминологии Ю. С. Степанова) становится все более актуальным в современной лингвистике. Обращаясь к анализу таких прагматических единиц, как «дискурсивные слова» (далее - ДС), мы следуем терминологической традиции, восходящей к французской концепции "les mots du discours" [Ducrot, 1980] и отечественных исследователей [Баранов, Плунгян, Рахилина, 1993]. Учитывая существующие подходы к исследованию ДС, мы обозначаем их как класс единиц, возникших в языке в результате перехода из знаменательных и служебных частей речи, первичная денотация которых стирается или искажается в «коммуникативных» употреблениях, в функциональный класс речевых единиц, выражающих интенции, эмоциональную и дискурсивную стратегию участников коммуникации (в том числе поэтической коммуникации). Так, при интерпретации ДС на первый план выводится их прагматический потенциал. Например, при разборе ДС смотри отметим, что данная лексема выражает интенцию предупреждения, предостережения, угрозы: Смотри, будешь болтать, погубишь не только себя, но и всех нас [Василий Гроссман. Жизнь и судьба. 1960. Ч. 2]. При этом в первом круге употреблений глагол смотpemь имеет значение «направлять взгляд, чтобы увидеть кого-что-н.» [Ожегов, 2008-2017]. Следовательно, его императивная форма в недискурсивной функции трактуется как призыв к указанному действию. Также для определения ДС необходимо указать на его непереводимость в косвенную речь, для трансформации в которую оно заменяется на предикат, обозначающий интенцию говорящего (Он предупредил меня, что, если буду болтать...). Здесь же заметим, что ДС, как правило, полифункциональны и их толкование возможно только в рамках определенной речевой ситуации: приведенное употребление единицы смотри не является единственным вариантом ее дискурсивной реализации.

Таким образом, под ДС мы понимаем «незнаменательные слова или словосочетания, которые регулируют дискурсивный процесс между говорящим и адресатом», «не несут пропозициональной информации» [Кибрик, Подлесская, 2009, с. 146], и генетически восходят к модальным словам, частицам, междометиям и т. д., выступая трансляторами взаимодействия адресанта и адресата, а также отношения актанта к сообщению [Баранов, Плунгян, Рахилина, 1993] ${ }^{2}$. Помимо ослабления синтаксических связей и денотативного

${ }^{2}$ Также мы учитываем концепцию И. А. Шаронова, в чьих исследованиях подчеркивается принципиальное различие дискурсивной функции, выполняя которую слово (ДС) выступает в качестве модификатора высказывания, и репликовой функции, где языковая единица (коммуникатив) выполняет самостоятельный ответный речевой акт [Шаронов, 2016]. 
значения, для данных единиц характерна грамматическая неизменяемость. Неоднородность класса, в состав которого входят ДС, обусловлена тем, что в них, в отличие от знаменательных единиц, повышается значимость недескриптивных, прагматических функций, а также тем, что состав этой группы пополняется за счет процессов транспозиции, грамматикализации и лексикализации ${ }^{3}$.

Значимость изучения этих процессов не только в диахронии, но и в синхронии обусловлена исследованиями категориально-семантических модификаций в современном употреблении, чему посвящены исследования Ю. Д. Апресяна, Н. Д. Арутюновой, Н. Н. Болдырева, Анны А. Зализняк и др. Так, значимое для данной работы явление семантического перехода обнаруживает себя в форме реализации по типу синхронной полисемии, осуществляемой на основании наличия концептуальной смежности между двумя языковыми значениями. Согласно теории семантических переходов Анны А. Зализняк, грамматикализация понимается в качестве частного случая этого процесса, целью которого оказывается переход неграмматической единицы в грамматическую или обретение единицей большего количества грамматических свойств, входящих в универсальный грамматический набор [Зализняк, 2013]. При этом наряду с грамматикализацией как в диахронии, так и в синхронии наблюдается обратный процесс, который исследователи обозначают «ресемантизацией» или «обратной семантизацией». Проблема ресемантизации ДС, которую мы обсудим в данной статье, практически не рассмотрена в сфере лингвистических исследований, в отличие от такого схожего феномена, как дефразеологизация, исследованная лингвистами В. М. Мокиенко, А. В. Жуковым, А. Г. Назаряном, З. Д. Поповой, Н. Л. Шадриным и др. Обращение к понятию дефразеологизации в данной работе обусловлено наличием такой общей черты этих единиц, как стереотипность, а также вхождением коллокаций в группу ДС. Языковая стереотипность реализуется посредством использования готовых речевых формул, включающих различные устойчивые сочетания, формулы этикета, клише, пословицы, поговорки и идиомы [Виноградов, 1977 ; Мокиенко 1986 ; и др.]. Обозначенная клишированность ДС, как и фразеологических единиц, помимо стандартизированной контекстуальной приемлемости ${ }^{4}$ в рамках реализации определенной дискурсивной стратегии, обнаруживается также и в следующих семантико-грамматических признаках: частичная или полная десемантизация, утрата словоизменительной возможности, внутренняя «аморфность грамматической модели» (в терминологии И. А. Шаронова) при многокомпонентной модели единицы.

Итак, под дефразеологизацией в современных исследованиях понимается модификация устойчивых выражений, при которой нарушается их традиционная структура. Такое преобразование подразумевает изменение постоянного лексического состава, а также грамматических форм компонентов фразеологической единицы. Для характеристики трансформации фразеологической единицы как неаддитивного словосочетания 5 , когда оборот перестает существовать как устойчивый, в лингвистике используются термины: «разрушение», «фразеологические осколки», «конденсаты», «дефразеологизация», «распад» (в терминологии Н. М. Шанского, П. А. Леканта, И. Я. Лепешева, А. Г. Ломова и др.). А. Г. Назарян определяет дефразеологизацию в качестве явления, при котором фразеологическая единица распадается на самостоятельные компоненты, приобретающие собственные значения [Назарян, 1978]. Определение, данное Л. В. Поповой, интересно для нашей работы тем, что в нем исследователь отмечает двойственный эффект, который достигается

${ }^{3}$ Диахронические изменения языка (грамматикализации и лексикализации) также исследовались в трудах В. А. Плунгяна, В. Неіпе и др. Особенности формирования группы дискурсивных единиц рассматривала Р. И. Бабаева.

${ }^{4}$ О понятии речевой приемлемости см.: [Демьянков, 2019].

${ }^{5}$ Сочетания, обладающие значениями или функциями, несводимы к значениям или функциям составляющих частей. 
в результате восстановления «реального смысла сочетания и реальных связей его компонентов в определенной ситуации с привычным лексическим окружением при сохранении или обогащении образно-переносного значения фразеологизма» [Попова, 1968, с. 115]. Таким образом, с одной стороны, сохраняется образно-типизированное значение сочетания в его узнаваемых «осколках», а с другой стороны, в результате разрушения устойчивого оборота, к его компонентам возвращается исходный смысл, грамматические и синтаксические признаки и свойственные им дескриптивные функции. Иными словами, под дефразеологизацией понимается двойная актуализация выражения и модифицированные вплоть до полного семантического распада единицы ретроспективно маркируют присутствие идиоматического значения в высказывании. В этом плане особый интерес для нас представляют фразеологические исследования, направленные на изучение авторских модификаций.

В ходе дальнейшего проведенного нами анализа при ресемантизации ДС в рамках поэтического дискурса во многих случаях функция, свойственная конвенциональному употреблению этого слова, полностью или частично сохраняется, но при этом ДС подвергается метаязыковой рефлексии, нацеленной на «деавтоматизацию» восприятия стереотипных единиц. Этим обусловлено наше обращение к поэтическому дискурсу ввиду характерной для него лингвокреативности на фоне узуса, ибо именно поэтическое употребление языка подразумевает попытку совместить повышенное внимание к лингвистической конвенции (в нашей случае - стереотипным единицам) с ее нарушением.

В этом плане особый интерес для нашего исследования представляют фразеологические исследования, посвященные авторским трансформациям фразеологизмов, среди которых можно назвать работы В. П. Вомперского (фразеология В. В. Маяковского), К. И. Мурзахановой (фразеология А. Т. Твардовского), О. Г. Сальниковой (фразеология А. Н. Толстого), П. Ф. Успенского и В. В. Файнберг (фразеология О. Э. Мандельштама и др.).

Авторские преобразования фразеологизмов в основном классифицируются по двум основным типам: 1) семантические (к ним относят обыгрывание прямого несвязанного значения отдельных компонентов, соединение (совмещение) или противопоставление свободного и фразеологически связанного значения всего словосочетания) и 2) структурные (появление новых слов, субституция и грамматическая перестройка компонентов, изменение их последовательности). Данная классификация отражена в работах А. Г. Ломова, Г. Н. Абреимова и др.

Однако анализ таких единиц, как ДС, требует разработки особых теоретических оснований и исследовательского инструментария, что связано с их спецификой по отношению к фразеологическим единицам. Дискурсивный подход позволяет более подробно рассмотреть некоторые отдельные случаи реализации сходного с этим процессом приема в поэтическом дискурсе. При этом особенно значимым представляется исследование прагматики поэтического дискурса в отношении явления лингвокреативности ${ }^{6}$. В отличие от других типов дискурса, для которых характерна «дискурсивная» креативность (например, для рекламного, политического и др.), поэтический дискурс ориентирован на «языковую креативность» в связи с установкой на «создание новых, уникальных языковых единиц и модификацию отношений между ними с целью кардинальной трансформации языковой системы», «активизацию межуровневого взаимодействия и контекстуально обусловленных функциональных переходов», а также «доминирование эстетической функции» [Соколова, 2020 , с. 124]. Направленность поэтического сообщения само на себя, его автореференциальность и актуализация «внутренней формы» слова определяют установку поэтического дискурса на языковое творчество ${ }^{7}$.

${ }^{6}$ Языковое творчество в языке и разных типах дискурса подробно анализируется в работах О. К. Ирисхановой, В. З. Демьянкова, R. Carter, И. В. Зыковой, М. И. Киосе и др.

${ }^{7}$ Подробнее о лингвокреативных основаниях художественного и поэтического дискурса см.: [Захаркив, 2019 ; Feshchenko, 2020]. 
Учитывая выбранный для анализа аспект креативной реализации устойчивых единиц, обладающих свойством идиоматичности, значимым для нас является определение лингвокреативности И. В. Зыковой, сформированное в аспекте фразеологии, которое охватывает свойства языковой системы в целом. По ее мысли, лингвокреативность - это «процесс построения языковой системы (ее разных уровней), особую роль в котором играет культура и личность (коллективная и индивидуальная), и процесс использования в практике живого речевого общения между представителями одного или разных лингвокультурных сообществ» [Зыкова, 2017, с. 628].

В настоящем исследовании мы будем использовать термин «ресемантизация» в том же значении, в котором в большинстве случаев употребляется понятие «обратная семантизация» - возвращение исходных смыслов компонентам десемантизированной единицы. Однако этот термин представляется более точным в данном контексте в силу отображения в нем конкретного явления, реализующегося вследствие авторской лингвокреативной модификации. Такая «экспериментальная модификация» (в терминологии О. В. Соколовой) включает в себя изменение значения единиц, необязательно в пользу исходного, так как многие ДС в принципе не обладают лексическим значением или утратили его (междометия, маркеры хезитации, частицы).

Термин «ресемантизация» не имеет устоявшегося определения в лингвистике. В более узком понимании «ресемантизация» как «идеологическая деидентификация» [Вепрева, 2005], или «деидеологизация», представляет собой процесс, в результате которого слово приобретает либо исходное, либо новое или дополнительное значение вследствие его деидеологизации и других объективных социокультурных и политических причин. В более широком понимании, ресемантизация означает процесс переосмысления, в результате которого слово переходит из пассивного запаса в активный. Учитывая, что наше исследование проводится на материале поэтического дискурса, мы определяем ресемантизацию как авторский прием, реализуемый посредством модификации лексического значения и функциональной нагрузки единицы, а также в некоторых случаях снятия с ДС свойственной им стереотипности и осмысления их в качестве семантических единиц ${ }^{8}$. Таким образом, явление ресемантизации ДС связано как с буквализацией значений отдельных компонентов неаддитивной единицы, так и с «депрагматикализацией» ДС. Также при обосновании выбора термина стоит учесть специфику ДС по отношению к фразеологическим единицам, денотация отдельных компонентов которых в случае их многокомпонентности модифицируется, в то время как у ДС утрата лексического значения сопровождается развитием новых прагматических функций. Подчеркнем, что многие ДС изначально обладают только функциональным значением и не поддаются однозначной лексикографической интерпретации без привлечения различных конситуативных употреблений.

Исследование ресемантизации как частного художественного приема представляется актуальным для семантики, прагматики и исследований поэтического языка и дискурса, где семантические явления регулярно получают специфическую реализацию: полисемия имеет тенденцию реализовываться как паронимическая аттракция, а переосмысление грамматического и лексического значения слова сходным с дефразеологизацией образом как ресемантизация.

Рассмотрим прием ресемантизации ДС на материале англо- и русскоязычных текстов из авторского поэтического корпуса (800 русскоязычных и 800 англоязычных текстов, в основном датируемых периодом 1990-2020-х годов, и некоторых текстов более ранних авторов - Г. Стайн и Вс. Некрасова, что связано со спецификой их поэтики, сосредото-

${ }^{8}$ Подробнее см. пункт 2 «Соположение дискурсивных слов по принципу противопоставления» при анализе единиц «да» и «нет» настоящей статьи. 
ченной на метаязыковой рефлексии и концептуалистской автореферентности поэтического плана выражения, во многом положившей начало современной практике поэтического письма) и выявим основные разновидности экспериментальных модификаций в современном поэтическом дискурсе. Методы исследования составляют описательный, лексикографический, лингвопрагматический и компонентный анализ.

\section{1. Ресемантизация дискурсивных слов на основании паронимической аттракции}

Прием ресемантизации с паронимической аттракцией, в ходе которого наглядно демонстрируется разница между дискурсивным и недискурсивным использованием единицы, иллюстрируют следующие примеры ${ }^{9}$ :

1.1. Is a war at hand. Will it take our hands away.

On the other hand. Do we have hands for the taking.

E. Ostashevsky

1.2. Слово Бог есть

И слава Богу

Слава Богу

Если есть Бог

Вс. Некрасов

1.3. Нам же, отданным в жертву кривым саблям зноя, остается ночами зализывать рваные раны, мечтая, наконеи, о конце: особенно жаркий день и пекло, словно копье, пронзающее нас прямо в сердие.

Х. Закиров

В примере 1.1 эффект метаязыковой рефлексии достигается посредством актуализации полисемии слова hand в устойчивых и свободных сочетаниях. Во фрагменте употреблены две фразеологические единицы: at hand (под рукой = близко) с дополнительным компонентом war (война) и on the other hand (с другой стороны). Во втором, интересующем нас случае, в котором единица выступает в роли ДС, благодаря контекстному окружению (четыре употребления слова hand с разными значениями), внимание фокусируется на центральном компоненте вследствие его множественного воспроизведения. Такой повтор, актуализирующий полисемию единицы hand, частично возвращает ДС on the other hand исходную семантику компонентов, при этом сохраняя за единицей функцию метатекстового ДС с конвенциональным значением противопоставления (согласно словарю [MerriamWebster] on the other hand «используется для введения утверждения, которое контрастирует с предыдущим утверждением или представляет другую точку зрения». Cp.: He's a good guy. His brother, on the other hand, is a very selfish man [Там же]). Таким образом, здесь представлена двойная актуализация: при сохранении образно-переносного значения идиоматической единицы в ее функциональной реализации (On the other hand) акцент смещается на первичное значение центрального компонента hand (Will it take our hands away; Do we have hands for the taking).

В примере 1.2 этот же эффект достигается подобным образом — в ходе метаязыковой процедуры, реализуемой посредством введения различных синтаксических ролей центрального компонента (Бог), в первом употреблении выступающего в атрибутивном и/или

\footnotetext{
${ }^{9}$ Полужирным шрифтом выделены дискурсивные слова, подчеркиванием - паронимы и омонимы.
} 
предикативном качестве (Слово Бог (ecmb)), затем дважды в функциональном (в составе ДС Слава Богу, маркирующего положительную оценку реальности: «Употр. для выражения удовлетворения чем-н.)» [Ушаков, 2004, с. 69]) и в третьем — в роли субъекта (в условной конструкции) (если есть Бог). В этом фрагменте интересно отметить динамику двухэтапного семантико-функционального сдвига центрального компонента: от недискурсивного употребления (Слово Бог есть) к дискурсивному (Слава Богу) и обратно (если Бог есть). Проследим также модификацию модальности - от изъявительного (слово Бог есть) к сослагательному наклонению (если есть Бог), где в первом случае Бог подчеркнуто выступает в качестве означающего (есть не сам Бог, а слово «Бог») и/либо в функции элемента предиката в модификации части библейского стиха ( в качестве референта («По религиозным верованиям - верховное существо, стоящее над миром или управляющее им [Там же]). Наконец, укажем на аттракцию единиц «слово» и «слава» по принципу их фонетического подобия.

Можно предположить, что такой прием, помимо метаязыковой рефлексии, скрывает еще одну цель: в результате перечисления лингвистических альтернатив и вводимых ими вариантов значений, приблизиться к предъявлению наиболее «настоящего», неискаженного контекстом значения слова в поэтическом высказывании. Так, О. О. Служаева отмечает, что в процессе языковой игры Вс. Некрасов утверждает слово в его изначальном смысле, не интерпретируя, а открывая его в чистом виде [Служаева, 2016]. В подтверждение этой мысли приводится цитата из статьи Т. В. Казариной: «Позитивность искусства проявляется как раз в способности расчищать жизнь от предметов и идеологем, которыми она себя загромоздила, и текст - это освобожденная от них “территория”. Творчество понималось здесь как возвращение к незапятнанности чистого листа и “звучанию” тишины - к тому, что самодостаточно и метафизически предшествует всем прочим проявлениям бытия» [Казарина, 2004, с. 427]. В приведенном примере наглядно реализуется концептуалистская установка ${ }^{10}$ на разрушение стереотипности и клишированности властного дискурса через повтор тех же приемов, повышенное внимание к конвенциям и их интенсификацию. Это явление намеренного не-лингвокреативного употребления языка описано в статье В. В. Фещенко, посвященной исследованию языковой перформативности и (не)креативности в творчестве поэтов-концептуалистов, стремящихся обесценить концепцию нового и покончить с лингвистическим творчеством посредством «исполнения» естественного языка без изменений, а не его трансформации [Feshchenko, 2020].

В примере 1.3 подобный эффект достигается при смежном с ДС употреблении паронима, что в свою очередь усиливает экспрессивность высказывания благодаря контексту, представленному подчеркнуто эмоциональной, в определенном смысле патетичной лексикой и метафорами (жертва; рваные раны; копье, пронзающее сердще), а также коннотациям повторяемого компонента. В пользу последнего утверждения укажем на то, что при употреблении слова конец в фокус выводится периферийное значение смерти. В связи с анализом художественного дискурса О. В. Соколова отмечает, что эвфемистическая номинация производит «перефокусирование ${ }^{11}$ исходного наименования, повышая экспрессивность сообщения и позволяя расставить прагматические акценты, необходимые адресанту» [Соколова, 2015, с. 350]. Добавим, что в словаре значение смерти у слова конеи при-

10 Вс. Некрасов - один из основателей «московского концептуализма», направления в искусстве и в поэзии, чьи представители в своем творчестве критически осмысляли конвенциональное использование языка (властный дискурс), в частности стереотипы, которые активно использовались в дискурсе советской идеологии.

11 Проблема фокуса в коммуникативной лингвистике разрабатывается в исследовании Т. Е. Янко «Коммуникативные стратегии русской речи» [Янко, 2001], понятия перефокусирования и сдвиг фокуса исследуются в работе О. К. Ирисхановой «Игры фокуса в языке» [Ирисханова, 2014]. Под перефокусированием в художественном и экспериментальном типах дискурса понимается когнитивный механизм, включающий сдвиг фокуса внимания с конвенциальных способов описания объекта на окказиональные языковые элементы [Соколова, 2015, с. 272]. 
водится с пометой «разг.» [Ушаков, 2004], что также подчеркивает повышенную эмоциональность (свойственную обыденному дискурсу) анализируемого сообщения, нацеленную на максимальное увеличение воздействия на адресата.

1.4. Not as far as to mean.

I mean, I mean.

G. Stein

1.5. All nice wives are like that.

To Be

No please.

To Be

They can please

Not to be

Do they please.

Not to be

Yes please.

G. Stein

\section{6. thinking $\boldsymbol{i}$ think ithink}

Ch. Bernstein

В приведенных выше примерах $(1.4,1.5)$ привлекаются полные омонимы: формы слова полностью совпадают, их различное функционирование прослеживается из смены конструкции и появления новых синтаксических и семантических валентностей. В примеpe 1.4 на первом месте представлено ДС, так как в конвенциональной коммуникации оно традиционно предваряет высказывание или его часть в составе многочастного высказывания (ср. с русскоязычным аналогом «я имею в виду», «то есть»), а на втором месте находится двусоставное предложение (субъект + предикат). Так, грамматикализованная конструкция с утратившим свои семантические и синтаксические роли субъектом и предикатом с помощью повтора получает статус полнозначного высказывания.

В следующем же фрагменте (1.5) недискурсивное употребление реализовано в форме глагола please (угождать) в составе конструкции «субъект + предикат: модальный/ вспомогательный глагол + смысловой глагол» (They can please). В примере (1.6) применяется как паронимическая, так и омонимическая аттракция, ДС предположительно локализуется либо посередине (thinking $\boldsymbol{i}$ think $i$ think), либо в конце строки (thinking $i$ think $\boldsymbol{i}$ think) в зависимости от того, к чему именно относится импликатура с интенцией выражения мнения ${ }^{12}$ : ко всему высказыванию (думая, что я думаю, думаю) или только к одной из частей (думая, (как я) думаю, (что) я думаю). Можно предположить, что метаязыковая рефлексия здесь связана с самоиронией поэтического субъекта, наглядно демонстрирующего свою неспособность личным мнением повлиять на реальность, в частности на внутреннюю ментальную действительность адресанта высказывания, ибо, как отмечает Е. В. Падучева, «у придаточного предложения, подчиненного глаголу мнения... пропозиция с глаголом в индикативе имеет снятую утвердительность - подчиненная пропозиция не имеет истинностного значения, так что отрицание не может влиять на ее истинность» [Падучева, 2013, с. 31]. Таким образом, где бы ни локализовалась единица I think, ее присутствие (в том числе в отрицательной форме) не повлияло бы на безусловный факт мыслительного процесса субъекта и сопровождающей его на него же направленной рефлексией.

12 Предположение, что единица I think в данном примере выступает в качестве ДС, основывается на удовлетворении указанным в начале статьи критериям: она не несет пропозиционального значения, а отражает рефлексию высказывания говорящим. 


\section{2. Соположение дискурсивного слова по принципу семантического противопоставления}

2.1. Есть рецепты покруче: как сделать, Чтоб мы перестали быть

Вообще, вообще - и, в частности, сейчас и здесь

В примере 2.1 данный принцип семантического противопоставления подтверждается контекстом, отображающим дедуктивную стратегию размышления (от общего к частному), так же, как и используемые ДС (вообще - генерализирующий коннектор; в частности конкретизирующий (в терминологии О. Ю. Иньковой).

Отметим, что в приведенном фрагменте сопряжено омонимичное употребление вообще (в качестве ДС в первом случае и в качестве обстоятельства образа действия во втором), поэтому здесь можно говорить о семантико-прагматической несимметричности: если в первом случае автор обошелся омонимом в качестве пропозиционального высказывания, то во втором он прибегнул к объяснению: в частности, сейчас и здесь. Обозначим также употребление менее распространенного в обыденной коммуникации варианта конструкции «...вообще и... в частности» - модификации «от частного к общему» или «не будем мелочиться», приводимой в «Путеводителе по дискурсивным словам русского языка» [Баранов, Плунгян, Рахилина, 1993, с. 109]. Указанный вариант подразумевает инвертированный порядок расположения элементов, когда «общее» (класс) предшествует «частному» (элементу): «говорящий сначала приводит более релевантное положение, но все-таки добавляет и менее релевантное» [Там же]. Отметим, что «вообще» обычно употребляется вслед за именем «обобщенного» представителя класса, а в частности - после его возможной конкретизации (ср.: Думал о вас, о привлекательности вообще и вашей в частности [Ефремов И. Лезвие бритвы. 1963]). Этот прием перестановки компонентов также воспроизводится в рамках последующего словосочетания (сейчас и здесь), традиционно приводимого в другом порядке слов: «здесь и сейчас».

Метатекстовые ДС сополагаются с целью метаязыковой рефлексии их функционирования, а также отображения общей тенденции поэтического дискурса к семантической аномальности (противоречивости) и неоднозначности, о чем свидетельствуют следующие примеры соположения интерперсональных ДС:

2.2. я поняла в чём дело

всё округляется

да-нет

Н. Денисова

2.3. электричество

нам заменяет жизнь

сигнал

накопленный заряд

цепочка да-да-нет

вспыика

отблеск

титина ${ }^{13}$.

В. Светлов

13 Заметим, что в примере 2.3 единицы (да, нет), конвенционально выражающие базовые коммуникативные реакции, не только воплощают модель электромагнитного взаимодействия (++-), но и, как нам подсказывает контекст, реферируют к двоичному коду (110) как системе счисления, распространенной в современной цифровой технике, посредством которой, в свою очередь, осуществляется коммуникация сегодня. 
В приведенных двух примерах $(2.2,2.3)$ совмещение антонимичных ДС осуществляется посредством образования неологизма способом сложения основ. Заметим, что активное включение антонимических междометий $(\partial a$, нет) служит показателем автокоммуникативного конфликта ${ }^{14}$, при котором однозначно положительный или однозначно отрицательный ответ одинаково невозможны. При таком экспериментальном совмещении антонимических единиц реализуется тенденция к депрагматикализации ДС, которые больше не осуществляют зафиксированного за ними намерения согласия-отрицания, подтверждения-возражения (согласно первому кругу употреблений, приводимых в [Ожегов, 2008-2017]), но своим присутствием отсылают к ним, осмысляя проблему бинарности мышления/коммуникации/действительности в целом. Эту идею в полной мере иллюстрирует следующий фрагмент (2.4), в котором ДС обретают синтаксические роли и словообразовательные валентности, которых нет в узуальном употреблении, полностью утратив свою изначальную функцию:

\section{4. Есть у нас на да и нет}

Антинет

И антида!

$$
\text { Вс. Некрасов } 15
$$

Единицы $\boldsymbol{\partial a}$ и $\boldsymbol{\mu e m}$ депрагматикализируются и лишаются своей первичной функции репликовых единиц (коммуникативов), смещаясь из коммуникативной зоны, то есть из свойственного им контекста речевого взаимодействия, в нарративную. При этом инверсивный порядок слов указывает на «осколки» разговорного использования единиц, вступающих в субъектно-объектные отношения в рамках предложения. В первом случае $\partial а$ и нет употреблены в качестве дополнений (объектов), во втором - в качестве подлежащих (субъектов). Обратим внимание на эскалацию противопоставления, которая достигается посредством префикса «анти» (Антинет // И антида) и подчеркивает конвенциональную антонимию указанных единиц, реализуя метаязыковую рефлексию.

\section{3. Фрагментация дискурсивного слова}

А) Фрагментация ДС как окказиональный способ образования других слов, семантически не связанных с мотивирующим источником:

$$
\begin{aligned}
& \text { 3.1. You're } \\
& \text { A } \\
& \text { Swell } \\
& \text { bunch } \\
& <\ldots .> \\
& \text { We } \\
& R \\
& \text { Well }
\end{aligned}
$$

Ted Greenwald, Ch. Bernstein

Повторение компонента well в тексте по принципу паронимической аттракции позволяет сделать вывод о том, что выше (в начале фрагмента) представлена экспериментальная модификация единицы as well. В словаре Merriam-Webster as well трактуется как «в до-

14 Термин «автокоммуникативный конфликт» восходит к концепции автокоммуникации, предложенной Ю. М. Лотманом; под ним понимается реакция поэтического субъекта на собственное сообщение, противоречащая этому сообщению [Захаркив, 2019].

${ }^{15}$ Ср. с другими примерами из произведений этого же автора: - По-твоему я / Тетенька // По-моему я / твоя мама; Пожалуйста // что я могу / сказать // и что надо будет / сказать // Спасибо; Прощай трамвай / и здравствуй / троллейбус и т. д. 
полнение к тому, что сказано», формируя своеобразную контекстуальную синонимию заключенных в одно выражение метатекстового ДС as well со словом swell с неопределенным артиклем $a^{16}$. Ведь swell, согласно словарю Merriam-Webster, имеет значение «опухоль, набухание, разрастание», что, по нашему предположению, апеллирует к интерпретации приведенного ДС (дополнение к тому, что уже сказано), при этом опухоль как феномен появляется в дополнение к тому, что уже есть. Кроме того, такое сближение функциональной единицы и/или привлеченного через ее фрагментацию и перекомпоновку «осколков» существительного и наречия well «хорошо» в последней строке фрагмента приводит к эффекту энантиосемии компонента well: будучи составляющей частью «опухоли», он одновременно выражает положительную оценку состояния субъектов высказывания.

Б) Фрагментация слова с целью образования ДС:

$$
\begin{aligned}
& \text { 3.2. <говорила>, мол } \\
& \text { чанием своим } \\
& \text { И. Краснопер }
\end{aligned}
$$

Здесь слово «молчание» при привлечении индивидуально-авторского понимания внутренней формы слова распадается на два компонента: мол (этим. сокр. от глагола молвил; ДС с функцией маркирования цитирования, или ксенопоказатель (в терминологии Е. В. Падучевой), и чание (воспринимаемое как модификация слова чаяние). Так, ДС мол, будучи ксенопоказателем, в данном примере указывает на автокоммуникацию ${ }^{17}$, свойственную поэтическому дискурсу (так как оно употребляется после личной формы глагола говорила, относящегося к субъекту поэтического высказывания, и осуществляет остранение собственной речи). Можно заключить, что молчание здесь образно соотносится с поэтическим письмом - (авто)коммуникацией, реализуемой в ситуации безмолвия.

В) Распад неаддитивной единицы на самостоятельные компоненты:

\section{3. [в] за правда шний настоящий то есть стоя́ щиий сто́ящий чего сто щекотки щепотка по́том да про сто так про то что как бы не так}

\section{И. Краснопер}

В приведенном фрагменте как бы осуществляет функцию сравнения, а так модифицируется в дейктическую единицу с отрицанием (не так). Подчеркнем, что в таком сочетании как бы не так, являясь фразеологическим осколком, ретроспективно маркирует прагматическое значение ДС в репликовой функции (коммуникатива), выражающего категорическое несогласие или отказ от чего-либо [Ушаков, 2004, с. 328]. Таким образом, в данном фрагменте так же, как и примере 3.2, содержится прямое указание на поэтическую автокоммуникацию. Кроме того, отметим здесь осуществление депрагматикализации ДС посредством приобретения его компонентами другого значения и функции (при помощи контекстных повторений и воспроизведения приема фрагментации слов).

\section{Вывод}

Итак, мы рассмотрели прием ресемантизации ДС на материале корпуса современных англо- и русскоязычных текстов и выявили основные разновидности экспериментальных модификаций в поэтическом дискурсе: 1) ресемантизация ДС на основе паронимиче-

${ }^{16}$ Несмотря на то, что “swell”, как мы полагаем, в данном тексте выступает в качестве существительного (благодаря неопределенному артиклю $a$ ), мы также допускаем, что данная лексема отсылает к знаменитому шлягеру Л. Армстронга “Hello Dolly" (а именно к строчке “You're looking swell, Dolly”), учитывая, что в поэзии как Ч. Бернстина, так и Т. Гринвальда представлено активное взаимодействие с дискурсом массовой культуры.

${ }^{17}$ Модель поэтической автокоммуникации опирается на идею внутренней, или «интраперсональной», коммуникации Р. О. Якобсона [Якобсон, 1985, с. 320] и понятие поэтической «автокоммуникации» Ю. М. Лотмана [Лотман, 1992, с. 77]. 
ской аттракции, 2) соположение ДС по принципу семантического противопоставления и 3) фрагментация ДС. Посредством реализации приема ресемантизации ДС на основе паронимической аттракции достигается эффект метаязыковой рефлексии при помощи актуализации полисемии, возврата изначального значения компонентам, формирования дополнительных синтаксических ролей «центрального» компонента, модификации модальности, перефокусирования значений единицы с целью повышения воздействия сообщения на адресата. Кроме того, в рамках этой группы мы отметили реализацию характерной для концептуализма установки на разрушение стереотипности конвенционального дискурса через повтор клише, а также осуществление двойной актуализации ДС: при сохранении образнопереносного значения идиоматической единицы в ее функциональной реализации и смещении акцента на изначальное значение центрального компонента.

В результате анализа ресемантизации посредством соположения ДС по принципу семантического противопоставления мы вывели, что метатекстовые ДС сополагаются с целью метаязыковой рефлексии их функционирования, а также отображения общей тенденции поэтического дискурса к семантической аномальности и неоднозначности. Кроме того, было показано, что активное включение антонимических интер-/интраперсональных ДС $(\partial a$, неm) служит показателем автокоммуникативного конфликта и реализует тенденцию к депрагматикализации ДС.

Также мы выделили три разновидности ресемантизации прагматических единиц методом фрагментации ДС. В результате анализа этих подвидов фрагментации ДС мы заключили, что при помощи данной операции возможно установление контекстуальносинонимических отношений семантических и функциональных единиц, указание на автокоммуникативность поэтического дискурса, депрагматикализацию ДС и др.

Добавим, что повышенное внимание современных поэтов к прагматике поэтического текста как высказывания получает развитие в силу активизации канала передачи сообщения, обретающего статус интерфейса в интернет-пространстве. Ресемантизация ДС (как их переосмысление) реализует семантическую и прагматическую креативность поэтического дискурса на микроуровне, осуществляя метаязыковую рефлексию и разрушая клишированность конвенционального дискурса, активно взаимодействуя с множественными коммуникативными стереотипами и стратегиями, воздействующими на адресата в переполненном с точки зрения информативности пространстве новых медиа.

\section{Список источников}

1. Баранов А. Н., Плунгян В. А., Рахилина Е. В. Путеводитель по дискурсивным словам русского языка. - М. : Помовский и партнеры, 1993. - 207 с.

2. Большой толковый словарь русского языка / под ред. Д. Н. Ушакова. - М. : АСТ : Астрель, 2004. - 1268 с.

3. Вепрева И. Т. Языковая рефлексия в постсоветскую эпоху - М. : Олма-Пресс, 2005. — $384 \mathrm{c}$.

4. Виноградов В. В. Избранные труды: лексикология и лексикография. - М. : Наука, 1977. - $318 \mathrm{c}$.

5. Демьянков В. 3. Приемлемость, уместность и адаптация текста // Вопросы когнитивной лингвистики. - М., 2019. — № 4. - С. 9-19.

6. Зализняк Анна А. Семантический переход как объект типологии // Вопросы языкознания. - М. : Наука, 2013. - № 2. - С. 32-51.

7. Захаркив Е. В. Дискурсивные слова в современной русской поэзии: креативное vs обыденное словоупотребление // Зборник Матице српске за славистику. - Нови Сад : Матица српска, 2019. — № 96. - С. 177-196.

8. Зыкова И. В. Метаязык лингвокультурологии: константы и варианты. - М. : Гнозис, 2017. - $752 \mathrm{c}$.

9. Ирисханова О. К. Игры фокуса в языке: семантика, синтаксис и прагматика дефокусирования. - М. : Языки славянской культуры, $2014-320$ с. 
10. Казарина Т. В. Три эпохи русского литературного авангарда - Самара : Самарский университет, 2004. - 620 с.

11. Кибрик А. А., Подлесская В. И. Дискурсивные маркеры в структуре устного рассказа: опыт корпусного исследования // По материалам ежегодной Международной конференции «Диалог 2009». - Вып. 8 (15). — М. : Рос. гос. гуманит. ун-т, 2009. - С. 390-395.

12. Дискурсивные слова русского языка: опыт контекстно-семантического описания : коллектив. моногр. / под ред. К. Л. Киселевой и Д. Пайара. - М. : Метатекст, 1998. — 448 с.

13. Лотман Ю. М. Автокоммуникация: «Я» и «Другой» как адресаты (О двух моделях коммуникации в системе культуры) // Семиосфера. - СПб. : Искусство-СПБ, 1992. - С. 159-165.

14. Мокиенко В. М. Образы русской речи. - Л. : Изд-во Ленингр. гос. у-та, 1986. — 280 с.

15. Назарян А. Г. Фразеология современного французского языка - М. : Высшая школа, 1987. $-288 \mathrm{c}$.

16. Ожегов С. И. Толковый словарь русского языка / под общ. ред. Л. И. Скворцова. - 28-е изд., перераб. - М. : Мир и образование, 2015. - 1375 с. - Толковый словарь С. И. Ожегова онлайн. 2008-2017._- URL : https://slovarozhegova.ru/ (дата обращения: 15.03.2021).

17. Попова Л. В. О дефразеологизации устойчивых сочетаний // Проблема устойчивости и вариативности фразеологических единиц. - Тула, 1968. — С. 115-119.

18. Падучева Е. В. Русское отрицательное предложение. - М. : Языки славянской культуры, 2013. - $304 \mathrm{c}$.

19. Служаева О. О. Недетский случай Всеволода Некрасова: метафизика пустоты // Актуальные проблемы гуманитарных и естественных наук.— М., 2016. — № 73. - С. 69-72.

20. Соколова О. В. Дискурсы активного воздействия: теория и типология : дис. ... д-ра филол. наук : 10.02.19.- М., 2015. - 635 с.

21. Соколова О. В. Дискурс-«логофаг»: границы лингвокреативности и стереотипности в рекламе // Критика и семиотика. - Новосибирск : Ин-т филологии Сибир. отд-ния РАН, 2020. - № 1. - C. 114-142.

22. Фещенко В. В. От лингвоэстетики к лингвоэвристике: словотворчество в художественном и научном дискурсах // Критика и семиотика. - Новосибирск : Ин-т филологии Сибир. отд-ния РАН. - 2020. - № 1. - С. 92-113.

23. Шаронов И. А. Междометия в речи, тексте и словаре. - М. : Изд-во Рос. гос. гуманит. ун-та, 2008. - $292 \mathrm{c}$.

24. Шаронов И. А. Дискурсивные слова и коммуникативы // По материалам ежегодной Международной конференции «Диалог». — Вып. 15 (22). — М. : Изд-во Рос. гос. гуманит. ун-та, 2016. C. 605-615.

25. Якобсон Р. О. Избранные работы. - М. : Прогресс, 1985. - 460 с.

26. Янко Т. Е. Коммуникативные стратегии русской речи. - М. : Языки славянской культуры, 2001. - $384 \mathrm{c}$.

27. Ducrot O. Les Mots du discours - Paris : Les Editions de Minuit, 1980. — $240 \mathrm{p}$.

28. Feshchenko V. V. The Performative turn in Philosophy and Verbal Art: Moscow Conceptualism's Linguistic (non-?)creativity // Зборник Матице српске за славистику. — 2020. — N 97. — Pp. 87-104.

29. Fraser B. What Are Discourse Markers? // Journal of Pragmatics. - 1999. - Vol. 31. P. 931-952.

30. Merriam-Webster Dictionary. — URL : https://www.merriam-webster.com/ (дата обращения: 01.04.2021).

\section{References}

1. Baranov A. N., Plungyan V. A., Rakhilina E. V. Putevoditel' po diskursivnym slovam russkogo yazyka [A guide to the discourse markers of the Russian language]. Moscow, Pomovsky and the Partners Publ., 1993, 207 p. (In Russian).

2. Bol'shoi tolkovyi slovar' russkogo yazyka [Unabridged Explanatory Russian Dictionary] (ed. by) D. N. Ushakov. Moscow, AST, Astrel Publ., 2004, 1268 p.

3. Vepreva I. T. Yazykovaya refleksiya v postsovetskuyu epohu [Linguistic reflection in the postSoviet era]. Moscow, Olma-Press Publ., 2005, 384 p. (In Russian). 
4. Vinogradov V. V. Izbrannye trudy: leksikologiya i leksikografiya [Selected works: lexicology and lexicography]. Moscow, Science Publ., 1977, 318 p. (In Russian).

5. Dem'yankov V. Z. Acceptability, relevance and adaptation of the text. Voprosy kognitivnoi lingvistiki [Cognitive Linguistics Issues]. 2019, no. 4, pp. 9-19. (In Russian).

6. Zaliznyak Anna A. Semantic transition as an object of typology. Voprosy yazykoznaniya [Linguistics Issues]. 2013, no. 2, pp. 32-51. (In Russian).

7. Zakharkiv E. V. Discourse markers in Russian contemporary poetry: creative VS common usage. Zbornik Matica srpske for Slavic studies. 2019, no. 96. pp. 177-196.

8. Zykova I. V. Metayazyk lingvokul'turologii: konstanty $i$ variant [Metalanguage of cultural linguistics: constants and options]. Moscow, Gnosis Publ., 2017, 752 p. (In Russian).

9. Iriskhanova O. K. Metayazyk lingvokul'turologii: konstanty $i$ varianty [Focus games in language: semantics, syntax and pragmatics of defocusing]. Moscow, Languages of Slavic culture Publ., 2014, 320 p. (In Russian).

10. Kazarina T. V. Tri epokhi russkogo literaturnogo avangarda [Three epochs of the Russian literary avant-garde]. Samara, Samara University Publ., 2004, 620 p. (In Russian).

11. Kibrik A. A., Podlesskaya V. I. Discourse markers in the structure of oral narration: the experience of corpus research. Rossiiskiy Gosudarstvennyi Gumanitarny Universitet [Russian State University of Humanities]. Moscow, 2009, no. 8, pp. 390-395. (In Russian).

12. Kiselyova K. L., Payar D. (Eds.) Diskursivnye slova russkogo yazyka: opyt kontekstnosemanticheskogo opisaniya [Discourse markers of the Russian language: the experience of contextsemantic description]. Moscow, Metatext Publ., 1998, 448 p. (In Russian).

13. Lotman Yu. M. Autocommunication: "Myself" and "Another" as addressees (On two models of communication in the system of culture). Semiosfera [Semiosphere]. Saint-Petersburg, Iskusstvo-SPB Publ., 2000, pp. 159-165. (In Russian).

14. Mokienko V. M. Obrazy russkoj rechi [Images of Russian speech]. Leningrad, Leningrad University Publishing House Publ., 1986, 280 p. (In Russian).

15. Nazaryan A. G. Frazeologiya sovremennogo frantsuzskogo yazyka [Phraseology of the modern French language]. Moscow, Higher school Publ., 1987, 288 p. (In Russian).

16. Ozhegov S. I. Tolkovyi slovar russkogo yazyka. (Ed. by) L. I. Skvortsov [Explanatory Russian Dictionary]. $28^{\text {th }}$ edition, revised. Moscow, The World and Education, 2015, 1375 p. ; Tolkovyi slovar S. I. Ozhegova online. 2008-2017. Available at : https://slovarozhegova.ru/ (accessed: 15.03.2021). (In Russian).

17. Popova L. V. On defraseologization of stable combinations. Problema ustojchivosti i variativnosti frazeologicheskih edinits [The problem of stability and variability of phraseological units]. Tula, 1968, pp. 115-119. (In Russian).

18. Paducheva E. V. Russkoe otritsatel'noye predlozhenie [Russian negative sentence]. Moscow, Languages of Slavic culture Publ., 2013, 304 p. (In Russian).

19. Sluzhaeva O. O. A childish case of Vsevolod Nekrasov: metaphysics of emptiness. Aktual'nye problemy gumanitarnyh $i$ estestvennyh nauk [Actual problems of the humanities and natural sciences]. Moscow, 2016, no. 73, pp. 69-72. (In Russian).

20. Sokolova O. V. Diskursy aktivnogo vozdejstviya: teoriya i tipologiya [Discourses of active affecting: theory and typology]. Full text of diss. doct. philol. sciences. Moscow, 2015, 635 p. (In Russian).

21. Sokolova O. V. Discourse-"logophagus": the boundaries of linguocreativity and stereotypes in advertising. Kritika i semiotika [Criticism and semiotics]. Novosibirsk, 2020, no. 1, pp. 114-142. (In Russian).

22. Feshchenko V. V. From linguoaesthetics to linguoheuristics: word creation in artistic and scientific discourses. Kritika i semiotika [Criticism and semiotics]. Novosibirsk, 2020, no. 1, pp. 92-113. (In Russian).

23. Sharonov I. A. Mezhdometiya v rechi, tekste $i$ slovare [Interjections in speech, text and vocabulary]. Moscow, Publishing house of the Russian State University for the Humanities Publ., 2008, 292 p. (In Russian).

24. Sharonov I. A. Communicatives and discourse markers [Papers from the Annual International Conference "Dialogue"]. Moscow, Publishing house of the Russian State University for the Humanities Publ., 2016, pp. 605-615. (In Russian).

25. Yacobson R. O. Izbrannye raboty [Selected works]. Moscow, Progress Publ., 1985, 460 p. (In Russian). 
26. Yanko T. E. Kommunikativnye strategii russkoj rechi [Communicative strategies of Russian speech]. Moscow, Languages of Slavic culture Publ., 2001, 384 p.

27. Ducrot O. Les Mots du discours. Paris, Les Editions de Minuit, 1980, 240 p. (In French).

28. Feshchenko V. V. The Performative turn in Philosophy and Verbal Art: Moscow Conceptualism's Linguistic (non-?)creativity. Zbornik Matica srpske for Slavic studies. Novi Sad, Matica Srpska, 2020, no. 97, pp. 87-104. (In English).

29. Fraser B. What Are Discourse Markers? Journal of Pragmatics. Amsterdam, Elsevier, 1999, no. 31, pp. 931-952. (In English).

30. Merriam-Webster Dictionary. Available at : https://www.merriam-webster.com/ (accessed 01.04.2021).

\section{Информация об авторе}

Захаркив Екатерина Васильевна - младший научный сотрудник Научно-образовательного центра теории и практики коммуникации имени Ю. С. Степанова, Институт языкознания РАН. Почтовый адрес: 125009, Россия, Москва, Большой Кисловский переулок, 1, стр. 1.

\section{Information about the author}

Zakharkiv, Ekaterina - junior research scientist, Institute of Linguistics, Russian Academy of Sciences, Research Educational Centre of Communication Theory and Practice named after Yu. S. Stepanov. Postal address: 1, Bolshoi Kislovsky Lane, Building 1. Moscow, 125009, Russia.

Статья поступила в редакциию 04.04.2021; одобрена после рецензирования 17.04.2021; принята к публикации 20.04.2021.

Submitted 04.04.2021;

approved after reviewing 17.04.2021;

accepted for publication 21.04.2021. 
Иностранные языки в высшей школе. 2021. № 2 (57). С. 57-67.

Foreign Languages in Tertiary Education. 2021;2(57):57-67.

Научная статья

УДК 8-81`1

DOI: $10.37724 /$ RSU.2021.57.2.005

\title{
Кодирование денотата в эвфемизмах и загадках на тему беременности и рождения
}

\author{
Ольга Сергеевна Орлова \\ Институт языкознания РАН, Москва, Россия \\ OrlovaOlgaS@list.ru
}

Аннотация. Целью статьи является описание реализации принципа непрямой номинации в эвфемизмах и загадках на тему беременности и рождения в русскоязычной и англоязычной культурах. Основное содержание исследования составляет когнитивно-культурологический анализ указанных лингвистических феноменов метафорического характера. Установлено, что эвфемизмы и загадки, помимо общеизвестных различий, будучи непрямыми именованиями, обнаруживают сходство в механизме кодирования денотата, выявить которое позволяет когнитивно-культурологический подход. В заключении статьи сформулированы предложения по применению когнитивно-культурологического описания при исследовании непрямых номинаций, не относящихся к эвфемизмам и загадкам.

Ключевые слова: принцип непрямой номинации, эвфемизм, загадка, когнитивная метафора, образ, фрейм, фреймовый анализ, культурологический комментарий, культурная коннотация, когнитивнокультурологическое исследование.

Для цитирования: Орлова О. С. Кодирование денотата в эвфемизмах и загадках на тему беременности и рождения // Иностранные языки в высшей школе. 2021. № 2 (57). C. 57-67. DOI: 10.37724/ RSU.2021.56.1.005.

Original article

\section{Denotation Coding in Euphemisms and Riddles about Pregnancy and Birth}

\author{
Olga S. Orlova \\ Institute of Linguistics, Russian Academy of Sciences, Moscow, Russia \\ OrlovaOlgaS@list.ru
}

Abstract. The aim of the article is to describe the principle of indirect nomination in euphemisms and riddles about pregnancy and birth belonging to Russian-speaking and English-speaking cultures. The research is mainly concentrated on cognitive-cultural analysis of the linguistic phenomena under consideration, which are based on metaphors. The analysis reveals that euphemisms and riddles, having many common differences, also show some similarity in denotation encoding mechanism which can be seen due to research from a cognitivecultural perspective. In conclusion, the paper suggests using cognitive-cultural analysis to study other indirect nominations, apart from euphemisms and riddles.

Keywords: principle of indirect nomination, euphemism, riddle, cognitive metaphor, image, frame, frame analysis, cultural comment, cultural connotation, cognitive-cultural research.

For citation: Orlova O. S. Denotation Coding in Euphemisms and Riddles about Pregnancy and Birth. Foreign Languages in Tertiary Education. 2021;2(57):57-67 (In Russ.). DOI: 10.37724/RSU.2021.57.2.005.

(C) Орлова О. С., 2021 
В современной науке изучение процессов номинации и метафоризации, а также эвфемизации активно переводится в русло когнитивной лингвистики и лингвокультурологии, в связи с чем расширяется проблематика исследований и важнейшим остается вопрос об особенностях кодирования денотатов в языковых знаках непрямой номинации, в том числе в таких культурно-языковых феноменах, как эвфемизмы и загадки.

Под эвфемизмами в науке о языке понимаются «разрешенные слова и выражения, которые употребляются вместо тех, которые запрещены или ограничены в употреблении этикетными, этическими, правовыми, идеологическими нормами и обычаями, принятыми в данном культурно-языковом сообществе» [Ковшова, 2019, с. 36]. Эвфемизмы широко исследуются в номинативном, структурно-семантическом, коммуникативно-прагматическом, социолингвистическом, когнитивном и лингвокультурологическом аспектах [Крысин, 1994 ; Порохницкая, 2018 ; Ковшова, 2019 ; Allan, Burridge, 2006 ; и др.]. Загадки относятся к развлекательным жанрам устного народного творчества, а также литературного творчества. Под загадкой понимается «краткое иносказательное описание предмета, предлагаемое для разгадки» [Даль, 1863, с. 505-506]. В лингвистических исследованиях учеными освещаются вопросы структуры, семантики этого жанра, проводится анализ загадок непосредственно в коммуникации [Левин, 1978 ; Журинский, 1989 ; Топоров, 1994 ; Georges, Dundes, 1963 ; и др.]. У эвфемизмов как знаков языка и загадок как жанров традиционной культуры разный функционал и разные функции. Эвфемизмы употребляются с целью смягчения речи и вуалирования существа дела, выполняя преимущественно этикетную функцию. Загадка в традиционной культуре выступает средством накопления и передачи знания из поколения в поколение, а в современной культуре главным образом выполняет интеллектуальноразвлекательную и педагогическую функции. При этом и эвфемизмы, и загадки построены на сознательной ошибке в таксономии объектов, и эта ошибка обусловлена самими знаковыми функциями этих единиц. Эвфемизмы служат оптимальным средством для нейтрализации нежелательных тем и нацелены на семантическое перефокусирование, отчуждение нежелательного смысла от конкретного денотата. Загадкам свойственно установление дальних связей между объектом номинации и его образным описанием.

Эвфемизмы и загадки участвуют в кодировании культурно маркированных тем, подлежащих непрямому именованию. К таким темам издревле относится тема беременности и рождения. И эвфемизмы, и загадки на тему беременности и рождения являются своеобразными иносказаниями, восходящими к одному проявлению мифологического мышления - табу, то есть «запрету на употребление тех или иных слов, выражений или собственных имён» [Леонтьев, 1990]. Основным способом обозначения объектов, требующих табуирования, является их непрямая номинация. То, что было табуировано, становилось объектом загадывания и служило источником создания первых эвфемизмов. Ср.: загадка «Не помню, не вижу, не знаю (когда родился, как расту, когда умру)» [Митрофанова, 1968, с. 60] и устаревшие эвфемизмы дохаживает последние дни и пеar her time (дословно: «её время близко»), употреблявшиеся в значении «скоро родит». Табу как культурный запрет на прямое называние в эвфемизмах с течением времени выродилось в этикетный запрет, а в загадках трансформировалось в игровой запрет.

Можно утверждать, что эвфемизмы и загадки - особые знаки языка и культуры, поскольку в них отражаются особый взгляд на мир и те фрагменты картины мира, которые требуют особого кодирования, табуирования и в которых «хранится и транслируется культурная информация» [Ковшова, Гудков, 2017, с. 14]. Эвфемизмы и загадки, будучи носителями культурно значимой информации, «в процессе восприятия “считываются” одновременно двумя разными кодами - кодом языка и кодом культуры» [Там же, с. 5].

В эвфемизмах и загадках кодируется денотат. Несмотря на то что кодирование денотата в загадках и эвфемизмах осуществляется с различными целями, способы кодирования денотата в загадках и эвфемизмах обнаруживают сходство, заключающееся в использова- 
нии принципа непрямой номинации. Под принципом непрямой номинации понимается «преднамеренно иносказательное обозначение объекта» [Орлова, 2020, с. 4], наблюдаемое в эвфемизмах и загадках. Ср.: “There was two persons, goin' on, one day. One of them was in the rain. One got wet, and the other didn't get wet (a pregnant woman)" [Taylor, 1951, p. 354] (дословный перевод: «Шли однажды два человека. Один из них был под дождём. Один промок, а второй не промок»); «мы ждём аиста» («у нас будет ребёнок»). Основным способом реализации принципа непрямой номинации в эвфемизмах и загадках на тему беременности и рождения служит метафора. Ср. также: «Под поло́м, поло́м стоит кринка с творого́м (беременная женщина)» [Митрофанова, 1968, с. 52]; “the Birds and the Bees talk" (дословно: «разговор о птицах и пчёлах») - непрямое обозначение разговора с ребенком о том, откуда берутся дети.

Обнаружить сходство в кодировании денотата в эвфемизмах и загадках на тему беременности и рождения позволяет когнитивно-культурологическое исследование эвфемизма и загадки: когнитивный подход определит конституирующие признаки эвфемизма и загадки - те, на основании которых осуществляется кодирование денотата и создается метафора, а культурологический комментарий объяснит использование тех или иных образов в создании метафоры, лежащей в основе эвфемизмов и загадок (о когнитивно-культурологическом исследовании загадок см. также: [Ковшова, Орлова, 2018, 2020]; о когнитивнокультурологическом исследовании эвфемизмов см. также: [Орлова, 2019]).

Когнитивно-культурологический подход в описании эвфемизмов и загадок осуществляется в два этапа: фреймовый анализ и культурологический комментарий. Фреймовый анализ базируется на классической когнитивной структуре фрейма [Демьянков, 1996 ; Fillmore, 1985 ; и др.]; формализация фрейма в виде таблицы позволяет раскрыть когнитивное «устройство» кодирования и в эвфемизмах, и в загадках. При описании механизма кодирования необходимо опираться на приемы, разработанные в лингвокультурологии для экспликации культурной информации. Таким приемом является культурологический комментарий, под которым понимается вслед за М. Л. Ковшовой и Д. Б. Гудковым «модель культурной интерпретации языковых знаков, которая позволяет репрезентировать его культурную значимость» [Ковшова, Гудков, 2017, с. 86]. Культурологический комментарий создается на базе энциклопедических сведений, а также с помощью метода глубокой интроспекции, понимаемого, по В. Н. Телия, как попытка «вжиться» в процесс культурной референции вербального знака к предметной области культуры - ее текстам, концептам, мифологемам, символам, эталонам и т. д. [Телия, 2006].

Проведем когнитивно-культурологический анализ русской традиционной загадки о беременной женщине «В тёмном лесу выросла метлица, не вырвать, не вытащить, пока Бог не пособит» [Митрофанова, 1968, с. 52] (табл. 1).

Когнитивную структуру метафорического «устройства» загадки и эвфемизма составляют: исходная понятийная область-источник; область-цель; типовой сценарий, который отражает характерную для данной сферы последовательность ситуаций; понятийные компоненты, которые создают основу для уподобления; фреймы как структура представления стереотипных ситуаций, выделенные в них данные о существенном, типичном и возможном для такого представления; типовые слоты, элементы ситуации, конкретизация фрейма.

Фреймовый анализ выявляет типовые сценарии, конституирующие признаки и направления иносказательности, характерные для исследуемых объектов. Таким образом выявляется корреляция между признаками области-источника и области-цели. Отметим, что под областью-источником в данной работе понимается мыслимое и ищущее обозначение явление или процесс, а под областью-целью - искомое и найденное в языке средство выражения.

Такой подход отступает от традиционного описания структуры метафоры, в котором термины применяются противоположным образом. В построении фрейма мы исходим из поставленной задачи исследовать механизм кодирования беременности и рождения, ре- 
конструировать процесс трансформации исходной ситуации в ее непрямое преобразованное описание, при этом методологической опорой послужили положения в работе А. Н. Журинского о переходе загаданного объекта из исходного описания в преобразованное (см. подробнее: [Журинский, 1989]). Движение от прямого описания к непрямому предопределило логику построения фрейма, в котором областью-источником является прямое описание, которое движется к своей области-цели, для чего деформируется, элиминируется, искажается, заменяется образом, но в чем-то остается узнаваемым, поскольку для загадки важно быть отгаданной, для эвфемизма важно быть понятым. Таким образом, в структуре нашего анализа исходная понятийная область - область-источник - это кодируемый денотат (или концепт, свойства которого отражаются в иносказательном описании эвфемизмов и загадок), а новая понятийная область - область-цель - это закодированное или завуалированное представление об исходной понятийной области. Между областью-источником и областью-целью выстраивается проекция, которая позволяет выявить конституирующие признаки между этими областями, обнаружить соединяющую их когнитивную метафору (табл. 1).

Таблиия 1

Фреймовый анализ загадки

\begin{tabular}{|c|c|c|}
\hline $\begin{array}{c}\text { Прямая номинация } \\
\text { загаданного объекта } \\
\text { (беременная женщина) }\end{array}$ & $\begin{array}{c}\text { Когнитивная } \\
\text { структура загадки }\end{array}$ & $\begin{array}{c}\text { Иносказательное описание } \\
\text { загаданного объекта } \\
\text { (В тёмном лесу выросла } \\
\text { метлица, не вырвать, } \\
\text { не вытащить, пока Бог } \\
\text { не пособит) } \\
\end{array}$ \\
\hline Область-источник & Конституируюшие признаки & Область-иель \\
\hline $\begin{array}{c}\text { Антропная, } \\
\text { физиологическая, } \\
\text { пространственная, } \\
\text { временна́я, акциональная }\end{array}$ & $\begin{array}{c}\text { Пространственный, } \\
\text { временной, } \\
\text { акциональный }\end{array}$ & $\begin{array}{c}\text { Природная, растительная, } \\
\text { пространственная, временна́я, } \\
\text { акциональная, } \\
\text { духовная }\end{array}$ \\
\hline \multicolumn{3}{|c|}{ 1. Типовые сиенарии } \\
\hline $\begin{array}{c}\text { В течение } 9 \text { месяцев внутри } \\
\text { женщины растет } \\
\text { и развивается ребенок, } \\
\text { который с наступлением } \\
\text { положенного срока } \\
\text { рождается на свет }\end{array}$ & $\begin{array}{c}\text { Элемент 1, локализованный } \\
\text { в пространстве элемента } 2 \\
\text { время t (ситуация 1), } \\
\text { в определенное время покидает } \\
\text { пространство элемента } 2 \\
\text { (ситуация 2) }\end{array}$ & $\begin{array}{c}\text { В течение некоторого времени } \\
\text { в лесу растет метлица, которую } \\
\text { затем срывают }\end{array}$ \\
\hline \multicolumn{3}{|c|}{ 2. Конкретизаиия фрейма в статике } \\
\hline Ребенок & Элемент 1 & Метлица \\
\hline Мать & Элемент 2 & Тёмный лес \\
\hline Матка & $\begin{array}{c}\text { Составная часть элемента } 2 \\
\text { (пространство, в котором } \\
\text { локализован элемент } 2 \text { время t) }\end{array}$ & Земля в лесу \\
\hline \multicolumn{3}{|c|}{ 3. Динамическая конкретизация фрейма как сиенария } \\
\hline $\begin{array}{c}\text { Рост ребенка внутри матери } \\
\text { в течение } 9 \text { месяцев } \\
\end{array}$ & $\begin{array}{c}\text { Ситуация } 1, \\
\text { которая длится время } \mathrm{t} \\
\end{array}$ & $\begin{array}{c}\text { Рост метлицы в лесу } \\
\text { некоторое время }\end{array}$ \\
\hline Время наступления родов & Завершение ситуации 1 & $\begin{array}{c}\text { Воля Божья } \\
\text { («пока Бог не пособит») }\end{array}$ \\
\hline Роды & $\begin{array}{c}\text { Ситуация } 2 \\
\text { (элемент } 1 \text { покидает } \\
\text { пространство элемента 2) }\end{array}$ & Срывание метлицы \\
\hline
\end{tabular}


В таблице 1 показаны конституирующие признаки, составляющие основу для кодирования денотата в загадке. Антропный признак подменяется природным и растительным, благодаря чему мать в тексте загадки «превращается» в темный лес, материнская утроба, дающая жизнь, - в землю, «рождающую» растения, а ребенок, развивающийся внутри матери, - в метлицу, растущую в темном лесу. Физиологический признак подменяется духовным, и положенное время наступления родов описывается в загадке как воля Божья. Пространственный, временной и акциональный конституирующие признаки, общие для области-источника и области-цели, выявляют базовые когнитивные метафоры, на которых построена рассматриваемая загадка о беременной женщине: «беременность - рост» и «рождение - перемещение из одного пространства в другое». Когнитивная метафора как «понимание и переживание сущности одного вида в терминах сущности другого вида» [Lakoff, Johnson, 2008, p. 5] представляет собой наиболее обобщенный образ, которому уподобляется ситуация (событие, явление). При этом важно отметить, что в структуре загадки могут «переплетаться» несколько различных когнитивных метафор. Так, в основе рассматриваемой загадки лежат следующие когнитивные метафоры: «рождение человека - переход из одного пространства в другое» (в образе вырывания из земли сорняка, который трудно вырвать); «земля — мать» (в образе «рождающей» траву земли); «беременность — рост», и «человек - растение», воплощённые в уподоблении ребёнка, растущего и развивающегося в утробе матери, метлице, растущей в тёмном лесу.

Базовые для данной загадки когнитивные метафоры «беременность - рост» и «рождение - перемещение из одного пространства в другое» конкретизируются в тексте загадки в различных образах, прежде всего в природных и растительных, которые «маскируют» конституирующие признаки загадки. Образы, в которых представлены беременность и рождение ребенка в анализируемой загадке русского народа, понимаются в контексте русской традиционной культуры с опорой на ее знание.

Дополним фреймовое описание культурологическим комментарием, чтобы показать, «как "вплетается" в языковую семантику создаваемая в ходе интерпретации семантика культурная» [Ковшова, Гудков, 2017, с. 87], как их взаимодействие формирует семантику языкового знака. «В основе загадки русской традиционной культуры о беременной женщине лежит пространственная метафора. Ребенок, растущий в пространстве материнской утробы, загадывается в образе травы, растущей в земле, в пространстве темного леса; ребенок, покидающий пространство материнской утробы с наступлением положенного срока, представлен в образе травы, которую вырывают из земли - перемещают из того пространства, в котором она росла, в другое. Согласно словарю В. И. Даля, «метлика, метлина, метлица, метличка, метлик - сорная трава в хлебе» [Даль, 1863, с. 919]. Ср.: «Посеяли хлеб, а жнём метлу, да костру, неурожай»; «И велика, да метлика (негодная), и мала, да трава, т. е. съедомая, полезная, кормовая» [Там же].

Рождение ребенка в данной загадке описывается как избавление от сорняка, то есть освобождение от того, что мешает. Подобное сравнение типично для описания беременности в русской культурной традиции. Ср.: устаревшие эвфемизмы на тему беременности и родов, построенные на образном сравнении с ношей и тяжестью: рус. разрешиться от бремени («родить»); в тяготе/тягостях/тягости быть, тяжела, тяжёлая, в грузу, с грузом («беременна»); в труде, в трудах («рожает»), найти хомут («нарожать много детей») и др.; ср. также англ. bear a child («носить ребенка» - «быть беременной»), heavy of foot (дословно: «тяжела на ногу» — «беременна»), in labor, in travail (дословно: «в труде», «в работе» — «в родах») и др.

Растительные образы также часто используются в русской культуре для кодирования темы беременности. Ср.: «За мясной стеной лежит огурчик костяной (младенец в брюхе)» [Садовников, 1876, с. 112]. О зачатии ребенка говорят завязаться, о первенце - первая завязь, о рождающихся один за другим - плестись [Усачева, 2004, с. 499]. Среди русских 
эвфемизмов на тему беременности и рождения встречаются диалектные единицы, включающие растительные образы: наесться бобов, гороха в значении «забеременеть» [Плотникова, 1995, с. 201], найти в крапиве, найти под грибом, найти под ёлкой в значении «родить ребенка» и др.

Когнитивные метафоры «беременность - рост» и «рождение - перемещение из одного пространства в другое», как и растительные образы, в которых они часто конкретизируются, объединяют непрямые номинации на тему беременности и рождения русскоязычной и англоязычной культур. Ср.: "I'm as big as a lentil at six weeks grown / Soon my presence will be known / What am I? (A baby)” (дословный перевод: «Я размером с чечевицу вырос за 6 недель / Скоро моё присутствие станет заметно / Кто я? (малыш)»; have a pea in the pod (дословно: «иметь горошинку в стручке»); swallow a watermelon seed (дословно: «проглотить семечко арбуза»); have a watermelon on the vine (дословно: «иметь арбуз на плети») и др.

Для сравнения механизма кодирования денотата в загадках и эвфемизмах обратимся к когнитивно-культурологическому анализу эвфемизма англоязычной культуры have a watermelon on the vine (дословно: «иметь арбуз на плети») [Holder, 2008, p. 400], употребляющегося для непрямого именования беременности (табл. 2).

Таблииа 2

Фреймовый анализ эвфемизма

\begin{tabular}{|c|c|c|}
\hline $\begin{array}{l}\text { Прямая номинация } \\
\text { (be pregnant } \\
\text { быть беременной) }\end{array}$ & $\begin{array}{c}\text { Когнитивная } \\
\text { структура эвфемизма }\end{array}$ & $\begin{array}{c}\text { Иносказательное } \\
\text { (эвфемистическое) описание } \\
\text { have a watermelon on the vine) }\end{array}$ \\
\hline Область-источник & Конституирующие признаки & Область-цุель \\
\hline $\begin{array}{c}\text { Антропная, физиологическая, } \\
\text { пространственная, временна́я, } \\
\text { акциональная }\end{array}$ & $\begin{array}{c}\text { Пространственный, временной, } \\
\text { акциональный }\end{array}$ & $\begin{array}{c}\text { Природная, растительная, } \\
\text { пространственная, } \\
\text { временна́я, акциональная }\end{array}$ \\
\hline \multicolumn{3}{|c|}{ 1. Типовые сиенарии } \\
\hline $\begin{array}{c}\text { В течение } 9 \text { месяцев внутри } \\
\text { женщины растет } \\
\text { и развивается ребенок. } \\
\text { Когда наступает положенный } \\
\text { срок, ребенок рождается на свет. }\end{array}$ & $\begin{array}{c}\text { Элемент 1, локализованный } \\
\text { в пространстве элемента } 2 \\
\text { время } \mathrm{t} \text { (ситуация 1), } \\
\text { в определенное время покидает } \\
\text { пространство элемента } 2 \\
\text { (ситуация 2) }\end{array}$ & $\begin{array}{c}\text { В течение некоторого } \\
\text { времени арбуз растет } \\
\text { на плети. } \\
\text { Когда арбуз созревает, } \\
\text { его срывают. }\end{array}$ \\
\hline \multicolumn{3}{|c|}{ 2. Конкретизация фрейма в статике } \\
\hline Ребенок & Элемент 1 & Арбуз \\
\hline Мать & Элемент 2 & Огород/грядка \\
\hline Матка & $\begin{array}{c}\text { Составная часть элемента } 2 \\
\text { (пространство, в котором } \\
\text { локализован элемент } 2 \text { время t) }\end{array}$ & Плеть \\
\hline \multicolumn{3}{|c|}{ 3. Динамическая конкретизачия фррейма как сиенария } \\
\hline $\begin{array}{c}\text { Рост ребенка внутри матери } \\
\text { в течение } 9 \text { месяцев }\end{array}$ & $\begin{array}{c}\text { Ситуация } 1, \\
\text { которая длится время } \mathrm{t}\end{array}$ & $\begin{array}{c}\text { Рост } \\
\text { арбуза на грядке }\end{array}$ \\
\hline Время наступления родов & Завершение ситуации 1 & $\begin{array}{c}\text { Время } \\
\text { созревания арбуза }\end{array}$ \\
\hline Роды & $\begin{array}{c}\text { Ситуация } 2 \\
\text { (элемент } 1 \text { покидает } \\
\text { пространство элемента 2) }\end{array}$ & Срывание арбуза \\
\hline
\end{tabular}


В таблице 2 показано, как антропный и физиологический признаки подменяются природным и растительным, благодаря чему мать в эвфемизме представлена в образе огорода/грядки, материнская утроба — плети, ребенок - арбуза, а наступление родов - в образе созревания арбуза. Пространственный, временной и акциональный конституирующие признаки, общие для области-источника и области-цели, определяют базовые когнитивные метафоры, на которых построен рассматриваемый эвфемизм: «беременность - рост», «рождение - перемещение из одного пространства в другое».

Посредством культурологического комментария восстановим то, что «в речи транслируется и воспринимается нерефлексированно, мгновенно, в “свернутом" виде» [Ковшова, Гудков, 2017, с. 88]. В рассматриваемом эвфемизме рост ребенка внутри матери уподобляется росту арбуза на грядке: ребенок растет в животе матери подобно большому арбузу, который вырастает из маленького семечка. Образное сравнение беременной женщины с арбузом также основано на внешнем сходстве: живот будущей матери по форме напоминает арбуз. В традиционной культуре народов мира бахчевые культуры с их длинными плетьми издавна входили в обряды, которые должны были повлиять на продолжение рода [Усачева, 2004, с. 499]. В современной англоязычной культуре большое распространение получили мемы, поздравительные открытки и одежда для беременных с расцветкой или изображениями арбуза. В социальных сетях можно часто встретить фотографии будущих мам, увлекающихся боди-артом, разрисовывающих свой живот под арбуз.

Таким образом, фреймовое описание эвфемизмов и загадок позволяет объяснить механизм кодирования денотата, а интерпретация образа загадки и эвфемизма в пространстве языка и культуры объясняет использование составляющих их основу метафор. Когнитивный подход выявляет конституирующие признаки загадки и эвфемизма, а культурологический комментарий объясняет использование образов, участвующих в их создании. Конституирующие признаки в рассмотренных примерах обнаруживают большое сходство (табл. 3).

Таблица 3

Конституирующие признаки загадки и эвфемизма

\begin{tabular}{|c|c|c|}
\hline Русская загадка & Когнитивная структура & Английский эвфемизм \\
\hline $\begin{array}{c}\text { В тёмном лесу выросла метлица, } \\
\text { не вырвать, не вытащить, } \\
\text { пока Бог не пособит }\end{array}$ & $\begin{array}{c}\text { Конституирующчие } \\
\text { признаки }\end{array}$ & $\begin{array}{c}\text { Have a watermelon } \\
\text { on the vine }\end{array}$ \\
\hline Метлица & Элемент 1 & Арбуз \\
\hline Темный лес & Элемент 2 & Огород/грядка \\
\hline Земля в лесу & $\begin{array}{c}\text { Составная часть элемента } 2 \\
\text { (пространство, в котором } \\
\text { локализован элемент } 2 \text { время t) }\end{array}$ & Плеть \\
\hline $\begin{array}{c}\text { Рост } \\
\text { метлицы в лесу } \\
\text { некоторое время } \\
\end{array}$ & $\begin{array}{c}\text { Ситуация } 1, \\
\text { которая длится время t }\end{array}$ & $\begin{array}{c}\text { Рост } \\
\text { арбуза на грядке } \\
\text { некоторое время } \\
\end{array}$ \\
\hline $\begin{array}{c}\text { Воля Божья } \\
\text { («пока Бог не пособит») }\end{array}$ & $\begin{array}{c}\text { Завершение } \\
\text { ситуации } 1 \\
\end{array}$ & $\begin{array}{c}\text { Время } \\
\text { созревания арбуза } \\
\end{array}$ \\
\hline Срывание метлицы & $\begin{array}{c}\text { Ситуация } 2 \\
\text { (элемент } 1 \text { покидает } \\
\text { пространство элемента 2) }\end{array}$ & Срывание арбуза \\
\hline
\end{tabular}

Образные компоненты эвфемизма и загадки «помещают» на их конституирующие признаки подобно тому, как кирпичи укладывают на фундамент строящегося дома, и таким образом реализуется принцип непрямой номинации в эвфемизмах и загадках. 
Похожий механизм кодирования денотата может использоваться и в других эвфемизмах и загадках на тему беременности и рождения. Так, взяв за основу конституирующие признаки («элемент 1», «элемент 2», «пространство, в котором локализован элемент 2 время t», «ситуация 1, которая длится время t», «завершение ситуации 1 » и «ситуация 2 , в которой элемент 1 покидает пространство элемента 2»), лежащие в основе загадки «B тёмном лесу выросла метлица, не вырвать, не вытащитть, пока Бог не пособит» и эвфемизма have a watermelon on the vine, получим современную загадку англоязычной культуры о ребенке "I'm as big as a lentil at six weeks grown / Soon my presence will be known / What am I? (A baby)” и традиционный эвфемизм have a pea in the pod (дословно: «иметь горошинку в стручке»), употребляющийся для непрямого именования беременности. Ср.: «элемент 1»чечевица/горох (ребенок), «элемент 2»- огород/грядка (мать), «пространство, в котором локализован элемент 2 время $\mathrm{t}$ » - стручок (материнская утроба), «ситуация 1, которая длится время t» - рост чечевицы или гороха в стручке (рост ребенка внутри матери), «завершение ситуации 1»- созревание чечевицы или гороха (время наступления родов), «ситуация 2, в которой элемент 1 покидает пространство элемента 2» - сбор урожая (роды).

Дадим краткий культурологический комментарий к данным примерам. В рассмотренных примерах ребенок внутри матери сравнивается с маленьким зернышком чечевицы или уподобляется горошинке. Особенностью бобовых являются сильно увеличивающиеся в объеме при варке плоды, что во многих культурах мира издревле символизировало зарождение и начало новой жизни [Усачева, 2004, с. 499]. В сказках нередко обыгрывается мотив чудесного зачатия от съеденного плода, как правило из семейства бобовых [Там же]; в народе также существует поверье, что бобовые способствуют плодовитости.

Таким образом, реализация принципа непрямой номинации в загадках и эвфемизмах может осуществляться посредством метафоры или сравнения. Механизм кодирования денотата в загадках и эвфемизмах может быть раскрыт с помощью когнитивно-культурологического исследования. Когнитивный позволяет выявить конституирующие признаки эвфемизма и загадки, а культурологический комментарий объяснить использование тех или иных образов в их создании. Конституирующие признаки, лежащие в основе непрямых номинаций на тему беременности и рождения, соединяются с различными культурно детерминированными образами. Основанием для применения когнитивно-культурологического подхода к объяснению механизма кодирования денотата в загадках и эвфемизмах служит их метафорическое «устройство», содержащее культурно значимую информацию, а значит можно предположить, что применение когнитивно-культурологического подхода в исследовании других непрямых номинаций с насыщенной культурной коннотацией, построенных на метафоре или сравнении, позволит объяснить механизм кодирования их денотатов.

\section{Список источников}

1. Даль В. И. Толковый словарь живого великорусского языка. Ч. 1. - М. : О-во любителей рос. словесности, 1863. - $627 \mathrm{c}$.

2. Демьянков В. 3. Фрейм // Краткий словарь когнитивных терминов / под общ. ред. Е. С. Кубряковой. - М. : МГУ им. М. В. Ломоносова, 1996. - С. 187-189. — URL : http://www.infolex.ru/ Cs27.html (дата обращения: 23.12.2020).

3. Журинский А. Н. Семантическая структура загадки: неметафорические преобразования смысла / отв. ред. Н. В. Охотина. - М. : Наука, 1989. - 128 с.

4. Ковшова М. Л. Эвфемизмы и фразеологизмы: устойчивые структуры в аспекте эвфемизации // Вестник Московского государственного областного университета. Сер.: Русская филология. - 2019. - № 4. - С. 35-48.

5. Ковшова М. Л., Гудков Д. Б. Словарь лингвокультурологических терминов. - М. : Гнозис, 2017. - 192 c. 
6. Ковшова М. Л., Орлова О. С. Загадки о рождении: опыт когнитивно-лингвокультурологического исследования // Когнитивные исследования языка. - Вып. 35. - М. ; Тамбов, 2018. C. 44-51.

7. Ковшова М. Л., Орлова О. С. К вопросу о семантической структуре загадки. Когнитивный и культурологический комментарий как принцип исследования // Тульский научный вестник. Сер.: История. Языкознание. - 2020. - Т. 4. - С. 70-79.

8. Крысин Л. П. Эвфемизмы в современной русской речи // Русистика. - Берлин, 1994. № $1-2$. - С. $28-49$.

9. Левин Ю. И. Семантическая структура загадки // Паремиологический сборник : пословица, загадка : структура, смысл, текст. - М. : Наука, 1978. - С. 283-314.

10. Леонтьев А. А. Табу // Лингвистический энциклопедический словарь / гл. ред. В. Н. Ярцева. — М. : Сов. энцикл., 1990. — 682 с. — URL : http://tapemark.narod.ru/les/501b.html (дата обращения: 20.06.2019).

11. Митрофанова В. В. Загадки. - Л. : Наука, 1968. — 256 с.

12. Орлова О. С. Принцип непрямой номинации в загадках и эвфемизмах на тему рождения и смерти : автореф. дис. ... канд. филол. наук : 10.02.19. - М., 2020. - 22 с.

13. Орлова О. С. Когнитивно-лингвокультурологическое исследование эвфемизмов на тему рождения // Когнитивные исследования языка. - Вып. 36. - М. ; Тамбов, 2019, — С. 403-413.

14. Плотникова А. А. Бобы // Славянские древности : этнолингвист. слов. : в 5 т. / под общ. ред. Н. И. Толстого. - Т. 1. - М. : Ин-т славяноведения РАН, 1995. - С. 201-202.

15. Порохницкая Л. В. Концептуальные модели в семантике эвфемизма : моногр. - М : Моск. гос. лингвист. ун-т, 2018. - 167 с.

16. Садовников Д. Н. Загадки русского народа : сб. загадок, вопросов, притч и задач. - СПб. : Велби, 1876. - 345 с.

17. Телия В. Н. Послесловие. Замысел, цели и задачи фразеологического словаря нового типа // Большой фразеологический словарь русского языка. Значение. Употребление. Культурологический комментарий / отв. ред. В. Н. Телия. - М. : АСТ-Пресс, 2006. — С. 776-782.

18. Топоров В. Н. Из наблюдений над загадкой // Исследования в области балто-славянской духовной культуры. Загадка как текст 1. - М. Индрик, 1994. - С. 10-117.

19. Усачева В. В. Овощи // Славянские древности : этнолингвист. слов. : в 5 т. / под общ. ред. Н. И. Толстого. - Т. 3. - М. : Ин-т славяноведения РАН, 2004. - С. 495-500.

20. Allan K., Burridge K. Forbidden Words: Taboo and the Censoring of Language. - New York : Cambridge University Press, 2006. - 314 p.

21. Fillmore Ch. J. Frames and the semantics of understanding // Quaderni di semantica. — 1985. Vol. 6, no. 2. - Pp. 222-254.

22. Georges R. A., Dundes A. Toward a Structural Definition of the Riddle // The Journal of American Folklore. - 1963. - Vol. 76, no. 300. - Pp. 111-118.

23. Holder R. W. How Not To Say What You Mean. A Dictionary of Euphemisms. $-4^{\text {th }}$ ed. Oxford : The University of Oxford Press, 2008. - 410 p.

24. Lakoff G., Johnson M. Metaphors we live by. - Chicago : The University of Chicago Press, 2008. - $276 \mathrm{p}$.

25. Taylor A. English Riddles from Oral Tradition. Berkeley and Los Angeles. - California : University of California Press, 1951. — 959 p.

26. Our Family World : [сайт]. — URL : https://www.ourfamilyworld.com/fertility-and-pregnancy/ pregnancy-announcements/baby-riddles-and-answers/ (дата обращения: 23.06.2020).

\section{References}

1. Dal V. I. Tolkovy slovar zhivogo velikorusskogo yazyka. Chast 1. [Explanatory Dictionary of the Living Great Russian Language. Part 1]. Moscow, O-vo lyubiteley ros. Slovesnosti Publ., 1863, 627 p. (In Russian).

2. Demyankov V. Z. Frame. (Ed.) Ye. S. Kubryakova. Kratky slovar kognitivnykh terminov [Concise dictionary of cognitive terms]. Moscow, Moscow State University named after M. V. Lomonosov Publ., 1996, pp.187-189. Available at: http://www.infolex.ru/Cs27.html (accessed 23.12.2019) (In Russian). 
3. Zhurinsky A. N. Semanticheskaya struktura zagadki: Nemetaforicheskiye preobrazovaniya smysla [Semantic structure of riddles: Non-metaphorical transformations]. (Ed.) N. V. Okhotina. Moscow, Nauka Publ., 1989, 128 p. (In Russian).

4. Kovshova M. L. Euphemisms and phraseological units: frozen structures from the standpoint of euphemisation. Vestnik Moskovskogo gosudarstvennogo oblastnogo universiteta. Seriya: Russkaya filologiya [Bulletin of the Moscow Region State University. Series: Russian Philology]. 2019, no. 4, pp. 35-48. (In Russian).

5. Kovshova M. L., Gudkov D. B. Slovar lingvokulturologicheskikh terminov [Dictionary of linguacultural terms]. Moscow, Gnozis Publ., 2017, 192 p. (In Russian).

6. Kovshova M. L., Orlova O. S. Riddles about birth: cognitive-linguacultural research. Kognitivnye issledovaniya yazyka [Cognitive Studies of Language]. 2018, no. 35, pp.44-51. (In Russian).

7. Kovshova M. L., Orlova O. S. About the semantic structure of riddles. Cognitive and cultural comment as a means of research. Tulsky nauchny vestnik. Seriya: Istoriya. Yazykoznaniye [Scientific Bulletin of Tula. Series: History. Linguistics.] 2020, no. 4, pp. 70-79. (In Russian).

8. Krysin L. P. Modern Russian euphemisms. Rusistika [Russian Studies]. Berlin, 1994, no. 1-2, pp. 28-49. (In Russian).

9. Levin Yu. I. Semantic structure of riddles. Paremiologichesky sbornik. Poslovitsa. Zagadka (struktura, smysl, tekst) [Paremiological book. Proverb. Riddle (structure, sense, text)]. Moscow, Nauka Publ., 1978, pp. 283-314. (In Russian).

10. Leontyev A. A. Taboo. Lingvistichesky entsiklopedichesky slovar [Linguistic Encyclopaedical Dictionary]. Moscow, Sovetskaya entsiklopediya Publ., 1990. (In Russian). - Available at : http:// tapemark.narod.ru/les/501b.html (accessed 20.06.2019).

11. Mitrofanova V. V. Zagadki [Riddles]. Leningrad, Nauka Publ., 1968, 256 p. (In Russian).

12. Orlova O. S. Printsip nepryamoy nominatsii $v$ zagadkakh $i$ evfemizmakh na temu rozhdeniya i smerti [Principle of indirect nomination in riddles and euphemisms about birth and death: dissertation self-abstract]. Avtoref. dis. ... kand. filol. nauk: 10.02.19. Moscow, Institute of Linguistics RAS Publ., 2020, 22 p. (In Russian).

13. Orlova O. S. Cognitive-linguacultural research of euphemisms about birth. Kognitivnye issledovaniya yazyka [Cognitive Studies of Language]. 2019, no. 36, pp. 403-413. (In Russian).

14. Plotnikova A. A. Beans. (Ed.) N. I. Tolstoy. Slavyanskiye drevnosti. Etnolingvistichesky slovar [Slavic Ancientries. Ethnolinguistic dictionary]. In 5 vols. Vol. 1. Moscow, Institute of Slavic Studies RAS Publ., 1995, pp. 201-202. (In Russian).

15. Porokhnitskaya L. V. Kontseptualnye modeli v semantike evfemizma [Conceptual models in semantics of a euphemism]. Monograph. Moscow, Moscow State Linguistic University Publ., 2018, 167 p. (In Russian).

16. Sadovnikov D. N. Zagadki russkogo naroda. Sbornik zagadok, voprosov, pritch i zadach [Russian folk riddles. Book of riddles, questions, paroemias and puzzles]. Saint-Petersburg, Velbi Publ., 1876, 345 p. (In Russian).

17. Teliya V. N. Afterword. The idea, goals and objectives of a new type phraseological dictionary. (Ed.) V. N. Teliya. Bolshoy frazeologichesky slovar russkogo yazyka. Znacheniye. Upotrebleniye. Kulturologichesky commentary [Big phraseological dictionary of the Russian language. Meaning. Usage. Cultural comment]. Moscow, AST-Press Publ., 2006, pp. 776-782. (In Russian).

18. Toporov V. N. About riddles. Issledovaniya v oblasti balto-slavyanskoy dukhovnoy kultury. Zagadka kak tekst 1 [Research in the field of Balto-Slavic culture. Riddle as text. Part 1]. Moscow, Indrik Publ., 1994, pp. 10-117. (In Russian).

19. Usacheva V. V. Vegetables. (Ed.) N. I. Tolstoy. Slavyanskiye drevnosti. Etnolingvistichesky slova [Slavic Ancientries. Ethnolinguistic dictionary]. In 5 vols. Vol. 3. Moscow, Institute of Slavic Studies, RAS Publ., 2004, pp. 495-500. (In Russian).

20. Allan K., Burridge K. Forbidden Words: Taboo and the Censoring of Language. New York, Cambridge University Press, 2006, 314 p.

21. Fillmore Ch. J. Frames and the semantics of understanding. Quaderni di semantica. 1985, Vol. 6, no. 2, pp. 222-254.

22. Georges R. A., Dundes A. Toward a Structural Definition of the Riddle. The Journal of American Folklore. 1963, vol. 76, no. 300, pp. 111-118. 
23. Holder R. W. How Not To Say What You Mean. A Dictionary of Euphemisms. 4th ed. Oxford, University Press, 2008, $410 \mathrm{p}$. $276 \mathrm{p}$.

24. Lakoff G., Johnson M. Metaphors we live by. Chicago, The University of Chicago Press, 2008,

25. Taylor A. English Riddles from Oral Tradition. Berkeley, Los Angeles, University of California Press, 1951, $959 \mathrm{p}$.

26. Website Our Family World. Available at: https://www.ourfamilyworld.com/fertility-andpregnancy/pregnancy-announcements/baby-riddles-and-answers/ (accessed 23.06.2020).

\section{Ииформация об авторе}

Орлова Ольга Сергеевна - младший научный сотрудник Сектора теоретического языкознания ФГБУН «Институт языкознания РАН». Почтовый адрес: 125009, Москва, Большой Кисловский пер. 1 , стр. 1.

\section{Information about the author}

Orlova, Olga - junior research scientist, Department of theoretical linguistics, The Institute of Linguistics, Russian Academy of Sciences. 1 bld. 1 Bolshoy Kislovsky lane, 125009 Moscow, Russia.

Статья поступила в редакцию 16.04.2021;

одобрена после рещензирования 28.04.2021;

принята к публикаиии 29.04.2021.

Submitted 16.04.2021;

approved after reviewing 28.04.2021;

accepted for publication 29.04.2021. 


\section{РАЗДЕЛ ІІІ \\ ВЛИЯНИЕ УСЛОВИЙ ОБЩЕНИЯ НА ДИСКУРС}

Иностранные языки в высшей школе. 2021. № 2 (57). С. 68-78.

Foreign Languages in Tertiary Education. 2021;2(57):68-78.

Научная статья

УДК 81 '316.772.2

DOI: $10.37724 /$ RSU.2021.57.2.006

\section{О «переключении языкового кода» и смене темы разговора в диалогическом дискурсе терциарной речи}

\section{Владимир Николаевич Бабаян}

Ярославское высшее военное училище противовоздушной обороны, Ярославль, Россия

vladimirbabayan@rambler.ru, https://orcid.org/0000-0002-7044-3419

Аннотация. Исследование посвящено одной из актуальных проблем речевой коммуникации - изучению особенностей диалогического дискурса терциарной речи с «переключением» языка общения и (частичной/полной) сменой темы разговора как результата акта общения всех его участников - активных и пассивных. Терциарная речь представляет собой диалог двух активных участников коммуникативного акта в присутствии третьего молчащего лица (группы лиц), явно не участвующего в акте коммуникации - диалоге - двоих коммуникантов, но своим присутствием оказывающего значительное влияние на вербальное и невербальное поведение общающихся и этим формирующего диалог в триаде при условии осведомленности активных коммуникантов о присутствующем пассивном третьем лице. В работе анализируются триады, в которых в присутствии молчащей третьей стороны в терциарной речи коммуникантов наблюдается «переключение кодов», то есть коммуниканты в процессе общения переходят с одного языка на другой (при билингвизме) или меняют (полностью/частично) тему своего разговора. Кроме того, в речи общающихся могут наблюдаться и иноязычные вкрапления - отдельные лексические единицы и словосочетания другого языка или нескольких языков. Причиной подобных модификаций служит изменение социальной ситуации конкретного речевого акта. Таким образом, молчащий участник диалога, присутствующий при разговоре двоих партнеров по общению, фиксируется коммуникантами в рамках конкретной коммуникативноречевой ситуации и влияет как на содержание, так и на форму диалога. Вследствие этого исследователь и включает молчащего участника в данную коммуникативно-речевую ситуацию и учитывает факт вовлеченности его в конкретный акт коммуникации. Приведены модели диалогов терциарной речи, в которых наблюдается «переключение языкового кода» при билингвизме, производимое коммуникантами, или (полная/частичная) смена темы разговора. Исследовано речевое и невербальное поведение всех - активных и пассивного - участников триадного диалога, выявлена в процессе анализа триадных диалогов роль молчащего наблюдателя в триаде.

Ключевые слова: терциарная речь, диалогический дискурс, триада, триадный диалог, переключение кодов, смена темы разговора, активные члены триады, молчащий наблюдатель.

Для цитирования: Бабаян В. Н. О «переключении языкового кода» и смене темы разговора в диалогическом дискурсе терциарной речи // Иностранные языки в высшей школе. 2021. № 2 (57). C. 68-78. DOI: 10.37724/RSU.2021.57.2.006.

(C) Бабаян В. Н., 2021 
Original article

\title{
On 'Code Switching' and Changing the Conversation Topic in a Tertiary Speech Dialogical Discourse
}

\author{
Vladimir N. Babayan \\ Yaroslavl Air Defence Higher Military College, Yaroslavl, Russia \\ vladimirbabayan@rambler.ru, https://orcid.org/0000-0002-7044-3419
}

\begin{abstract}
The article studies tertiary dialogical discourse with 'code switching' and (complete/partial) changing of the theme as a result of a silent bystander's (group of silent bystanders) presence in a two-person talk. Tertiary communication presents a dialogue of two speakers as active interlocutors in the presence of a silent bystander (silent bystanders) as its third passive participant. The silent bystander's role in a dialogue is quite significant, as his presence influences both the speakers' verbal and nonverbal behavior and results in a special type of a triadic dialogue formation. Tertiary speech implies certain changes in the speakers' verbal behavior if they are aware of the silent bystander's presence in their speech situation. The author analyses the dialogues in a triad characterized by 'code switching' and partial or complete changing of the conversation theme. Besides, with a change in the speech situation, the speakers can use foreign words and phrases while talking. Thus, the presence of a silent bystander is taken into account by the two speakers that have to switch codes or just change the theme of their talk. Therefore, the third silent and passive participant influences both the content and the form of the dialogue produced by its active participants. Thus, the silent bystander is included in the speech situation as his presence affects the dialogical discourse. The article presents models of a tertiary dialogue when the two active participants resort to 'code switching' and complete or partial changing of the theme, and provides analysis of all the active and passive participants' verbal and nonverbal behavior, as well as and the silent bystander's different roles in triadic dialogues.
\end{abstract}

Keywords: tertiary speech, dialogical discourse, triad, triadic dialogue, 'code switching', changing the theme of the talk, active tertiary speech participants, silent bystander.

For citation: Babayan V. N. On 'Code Switching' and Changing the Conversation Topic in a Tertiary Speech Dialogical Discourse. Foreign Languages in tertiary Education. 2021;2(57):68-78. (In Russ.). DOI: 10.37724/RSU.2021.57.2.006.

\section{Введение}

В современном научном сообществе наблюдается усиление интереса к проблеме изучения дискурса. Различные аспекты дискурса становятся предметом исследования все большего числа отечественных и зарубежных ученых [Карасик, 2002 ; Макаров, 2003 ; Борботько, 2006 ; Денисов, 2012; Бабаян, 2016 ; Мельникова, 2019 ; Орлова, Богданова, Крамаренко, 2020; Crystal, 1987, 2005; Fromkin, Rodman, 1988; Garnham, 1994 ; van Dijk, 1996].

В настоящей работе исследуется диалогический дискурс терциарной речи. Понятие «диалогический дискурс» представляет связное речевое произведение (текст) как результат двустороннего речевого обмена партнеров по общению репликами-высказываниями (диалог), в котором они формируют и формулируют свои реплики-высказывания с учетом экстралингвистического фактора присутствия всех участников акта коммуникации с различными ролями, в том числе молчащих некоммуникантов [Бабаян, 2016, с. 26]. Под терциарной речью подразумевается диалог двух активных его сторон (далее АЧТ - активные члены триады) в присутствии третьей молчащей стороны - молчащего наблюдателя (далее МН), которым может быть лицо (лица), явно не участвующее в акте коммуникации, но своим присутствием влияющее на вербальное и невербальное поведение общающихся и тем самым формирующее диалог в триаде. Так, под воздействием присутствия МН общение в диаде трансформируется в диалог в триаде, что приводит к модификации самой формы и содержания диалога АЧТ. Итак, «диалог в триаде» представляет терциарную речь 
АЧТ в присутствии МН [Бабаян, 2016, с. 26]. В настоящей работе представляет интерес сам феномен третьего молчащего лица как члена триадного диалога (MH). Описанная ситуация дает основание включить МН в конкретную коммуникативно-речевую ситуацию [Бабаян, 2006, с. 168]. Очевидно, что два собеседника (АЧТ) в процессе разговора могут неодинаково реагировать на появление либо присутствие МН: партнеры по двустороннему речевому обмену могут о чем-то умалчивать и, наоборот, говорить о том, чего не стали бы говорить в отсутствие МН. В каждой коммуникативно-речевой ситуации воздействие молчащей третьей стороны на общающихся и соответственно на диалог как продукт их совместной речевой деятельности будет различным.

Рассмотрим модель диалога терциарной речи двух активных членов триады (АЧТ), в которой в присутствии МН в их речи происходит «переключение языкового кода» или смена темы разговора. Кроме того, в репликах-высказываниях АЧТ наблюдаются иноязычные вкрапления (отдельные слова и выражения из другого языка). Причиной тому является изменение социальной ситуации определенного коммуникативного акта.

Отметим, что таким образом формируется барьер между АЧТ и МН в определенном акте коммуникации. Разумеется, АЧТ остро ощущают нежелательность присутствия МН при их разговоре и всячески пытаются «отключить» его: АЧТ могут использовать в своей речи и особые термины, незнакомые (вольному/невольному) слушателю их разговора.

Считаем уместным заметить, что термин «переключение языкового кода» представляет собой перевод английского “code-switching” на русский язык. Работы по исследуемой проблеме впервые появились в англоязычной научной литературе в середине 70-х годов XX века.

Д. Кристал рассматривает переключение кодов как использование более одного языка, диалекта или варианта языка в процессе конкретного акта общения [Crystal, 1987, p. $11 ; 2005$, p. 459]. В. Фромкин и Р. Родман, исследуя речь коммуникантов-билингвов, говорящих, помимо испанского, на южных диалектах американского варианта английского языка, отмечают, что у этих коммуникантов-билингвов часто наблюдается переключение языкового кода даже в пределах одного высказывания-реплики (предложения) [Fromkin, Rodman, 1988, p. 269].

Возможность переключения кодов в пределах одной реплики-высказывания отмечает и отечественный лингвист Г.Н. Чиршева, занимающаяся проблемами билингвизма [Чиршева, 2000, с. 29]. Механизмы явления кодовых переключений способствуют лучшему взаимопониманию между партнерами по общению и обеспечивают относительную успешность процесса их вербального акта коммуникации.

Кодовое переключение может быть использовано в акте коммуникации в различных целях. Так, например, переключение кодов может способствовать выражению солидарности коммуниканта с определенной социальной группой. Когда адресант отвечает на переключение кода переключением такого же типа, между адресантом и адресатом образуется определенная связь; в то же время кодовое переключение может быть использовано и для того, чтобы исключить из конкретного разговора (беседы) нежелательных слушателей (третьих лиц), которые не знают язык (код), на который переключаются партнеры по общению.

Итак, из вышесказанного можем заключить, что переключение кодов подразумевает переход коммуниканта (обоих собеседников) с родного языка (диалекта, стиля) на иностранный или с иностранного на родной в прочессе определенного акта коммуникации под воздействием конкретных условий общения.

\section{Анализ материала}

Рассмотрим примеры диалогического дискурса терциарной речи с «переключением кодов» и сменой темы разговора на материале русско- и англоязычных диалогов художественной литературы. 
(1) Рассказ «Слон» А. И. Куприна начинается с описания визита доктора Михаила Петровича к маленькой больной девочке, которую он навещал каждый день. Как пишет автор, «...иногда он [доктор Михаил Петрович] приводит с собою еще двух докторов, незнакомых». Они осматривают девочку и при этом «как-то важно посапывают, лица у них строгие, и говорят они между собою на непонятном (для девочки. - В. Б.) языке».

Потом врачи переходят из детской в гостиную, где их дожидается мать больной девочки. Михаил Петрович рассказывает ей о чем-то серьезно и долго. "Дверь не закрыта, и девочке с ее кровати все видно и слышно. Мама глядит на доктора больщими, усталыми, заплаканными глазами. Прощаясь, главный доктор говорит громко:

- Главное, - не давайте ей скучать. Исполняйте все ее капризы.

- Ах, доктор, но она ничего не хочет!

— Ну, не знаю... вспомните, что ей нравилось раньще, до болезни. Игрушки... какие-нибудь лакомства...

- Нет, доктор, она ничего не хочет...

- Ну, постарайтесь ее как-нибудь развлечь... Ну, хоть чем-нибудь... Даю вам честное слово, что если вам удастся ее рассмешить, развеселить, - то это будет лучшим лекарством. Поймите же, что ваша дочка больна равнодушием к жизни, и больше ничем... До свидания, сударыня! (жирный курсив наш. - В. Б.) [Куприн, 1982, с. 145-146].

При прочтении этого эпизода можно заметить, что в нем наблюдаются два диалога в триаде. Первый диалог состоится между врачами (АЧТ) в присутствии больной девочки эксплицитного молчащего наблюдателя (ЭМН). Автор описывает действия врачей: «Они переворачивают девочку на спину и на живот, случают что-то, приложив ухо к телу, оттягивают вниз нижнее веко и смотрят». Кроме того, при этом осмотре, как говорит А. И. Куприн, «...они (врачи, АЧТ. - В. Б.) говорят между собой на непонятном языке». Таким образом сознательно создается барьер между врачами (АЧТ) и МН в лице больной девочки. Другими словами, переключение языкового кода является вынужденным, врачи считают, что больной девочке не следует знать суть их разговора.

В исследуемой триаде наблюдается альянс, включающий главного доктора Михаила Петровича и двух его коллег, объединенных единой целью и соответствующей тактикой ведения разговора — вылечить больную девочку и не ухудшить ее состояние.

Данная триада схематично представлена на рисунке 1.

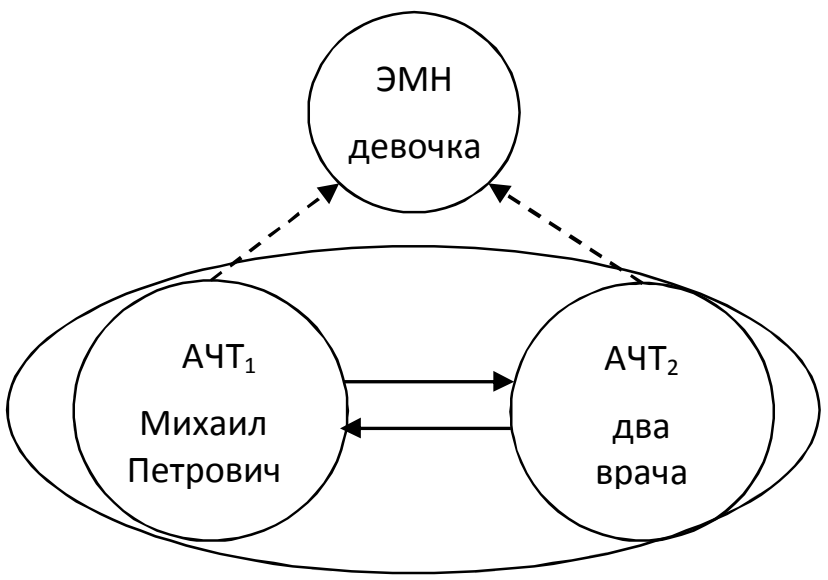

Рuc. 1. Схема триады из рассказа «Слон» А. И. Куприна

Второй диалог ведется между главным доктором (АЧТ 1 ) и матерью больной девочки (АЧТ 2 ) в гостиной. «Михаил Петрович рассказывает ей о чем-то серьезно и долго. Дверь не закрыта, и девочке (ЭМН. - В.Б.) с ее кровати все видно и слышно. Мама глядит на доктора большими, усталыми, заплаканными глазами». 
Диалог насыщен синтаксически короткими предложениями-рекомендациями врача: «...не давайте ей скучать. Исполняйте все ее капризы» и т. д., а также ответными репликами уставшей матери девочки, которая в отчаянии произносит: «Ax, доктор, но она (девочка, ЭМН. - В. Б.) ничего не хочет!»

Заметим, что, помимо Михаила Петровича и матери девочки (АЧТ), в гостиной присутствуют еще два врача, которые вместе с ним осматривали больную девочку, то есть еще два эксплицитных МН, поддерживающих Михаила Петровича (АЧТ 1 ) и соглашающихся с его советами-рекомендациями и тем самым составляющих с ним альянс.

Схема данной триады будет иметь следующий вид (рис. 2).

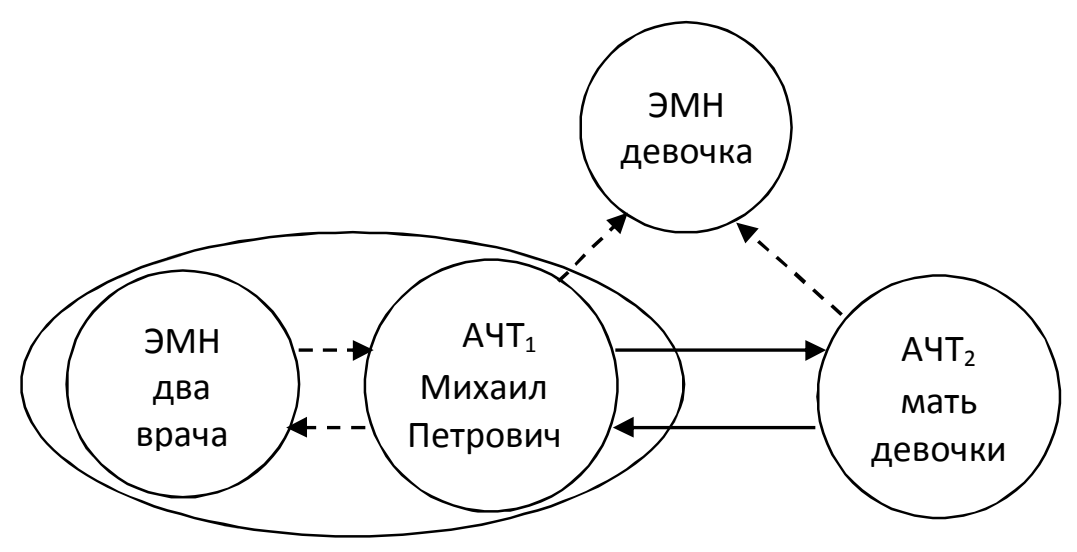

Рuc. 2. Схема триады из рассказа «Слон» А. И. Куприна

Как видим, больная девочка выступает в роли эксплицитного МН в обоих актах коммуникации, однако, если в первом диалоге врачей она ничего не понимает, во втором диалоге Михаила Петровича и ее матери она понимает все, о чем говорят АЧТ, и делает соответствующие выводы о своем состоянии, переживаниях матери и рекомендациях врачей.

(2) Наглядным примером модели диалога терциарной речи со сменой темы разговора служит эпизод из романа «Цитадель» А. Кронина, где Эндрю Мэнсон $\left(\mathrm{AЧT}_{1}\right)$ в присутствии врачей больницы (ЭМН) говорит с молодым специалистом Валленсом (АЧТ 2$)$ о Стилмене, их общем знакомом враче, работающем в США: in America.

...Andrew, with sudden interest, asked him if he had heard of Stillman while he was

"Yes, of course," said Vallance. "They think a lot of him out there. He has no diploma of course, but the State has recognized him, making an exception in his case because of his accomplishments. He gets the most amazing results."

"Have you seen his clinic?"

"No," Vallance shook his head. "I didn't get as far as Oregon."

Andrew paused for a moment, wondering if he should speak. "I believe it's a most remarkable place," he said at length. "I happen to have been in touch with Stillman over a period of years - he first wrote me about a paper of mine published by the Association of American Hygiene. I've seen photographs and details of his clinic. One couldn't wish for a more ideal place to treat one's cases. $<\ldots>$

Andrew broke off, deprecating his own enthusiasm, for a break in the general conversation made everything he said audible to the entire table. "When one thinks of our conditions in London, it seems an unattainable ideal."

Doctor Thoroughgood smiled with dry asperity.

"Our London physicians have always managed to get along very well in these same London conditions, Doctor Manson. We may not have the exotic devices of which you speak. But I venture to suggest that our solid, well-tried methods - though less spectacular - bring equally satisfactory and probably more lasting results." 
Andrew, keeping his eyes lowered, did not answer. He felt that as a new member of the staff he had been indiscreet in voicing his opinion so openly. And Doctor Thoroughgood, to show that he had intended no snub, went on very pleasantly to turn the conversation. He talked about the art of cupping (жирный курсив наш. - В. Б.) [Cronin, 1966, p. 353-354].

Анализируемый диалог терциарной речи представляет двойной интерес: во-первых, тем, что в процессе общения происходит смена темы разговора; во-вторых, тем, что смену темы разговора инициируют не сами АЧТ (Мэнсон и доктор Валленс), а один из присутствующих врачей (доктор Сороугуд). Доктор Сороугуд, как понимает и сам Эндрю Мэнсон, имеет на это право, поскольку он намного старше остальных как по возрасту, так и по должности и считается к тому же «ответственным» за Мэнсона и других молодых врачей. Замечаем и вполне естественную реакцию доктора Сороугуда, МH, на данный разговор ("smiled with dry asperity”), он тактично одергивает Мэнсона, словно хочет сказать: "Дорогой, так говорить в присутствии других нельзя!» Поэтому Эндрю Мэнсон "broke off, deprecating his own enthusiasm," осознавал свое неловкое положение и признавал, что он неправ. И мудрый, опытный Сороугуд решил “very pleasantly to turn the conversation," чтобы не привлекать внимание других присутствующих и не задерживаться на этом поступке. Ему удается подать хороший пример молодым врачам и тем самым сохранить беседу непринужденной.

Схема триадного диалога с ЭМН представлена на рисунке 3.

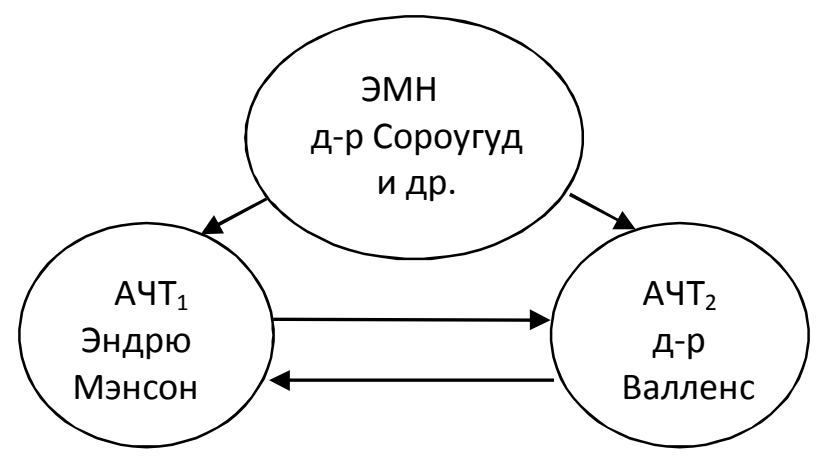

Puc. 3. Схема триады из романа «Цитадель» А. Кронина

Исследуемый диалог интересен также тем, что, в отличие от предыдущего, в нем третья сторона, МН, представлена не одним лицом, а целой группой врачей. Только доктор Сороугуд, один из МН, вербально реагируя на услышанное, становится еще одним коммуникантом, АЧТ.

(3) В романе «Под сетью» Айрис Мердок есть эпизод, в котором описывается, как писатель-переводчик Джейк Донагью приходит в дамскую парикмахерскую в поисках Сэди с просьбой разрешить ему временно поселиться у нее на время ее отъезда. Диалог Джейка Донагью $\left(\mathrm{AЧT}_{1}\right)$ с Сэди $\left(\mathrm{AЧT}_{2}\right)$ происходит в присутствии мастеров и клиентов парикмахерской, эксплицитных МН, реакцию и заинтересованность которых замечаем в процессе разговора АЧТ. Повествование ведется от лица Джейка (АЧТ 1 ):

"Hello, Sadie!" I said, and I didn't have to fake my delighted smile.

"My dear creature," said Sadie, "I haven't seen you for centuries! How lovely! Were you looking for me?"

I said that I was, and I fetched a chair and sat just behind her shoulder. We grinned at each other in the mirror, I thought we were a fine-looking pair. Sadie looked very handsome... $<\ldots>$ I quite involuntarily put my hand on her arm.

"You charming fellow!" said Sadie. "What sports do you devise these days? Tell me all!" $<\ldots>$

"Oh, I'm still at the old writing game. Books, books, you know. I've got about three on hand at the moment. And publishers will keep pestering me." 
"You always were such a clever chap, Jake," Sadie shouted admiringly.

Silence reigned throughout the rest of the shop $\langle\ldots\rangle$, and I could feel every ear strained in our direction (MH. - B. B.). < .. > I settled down to enjoy the conversation. < ...>

"Listen, Sadie," I said, lowering my voice.

"What's that, darling?" shouted Sadie from under the drier.

"Listen!" I shouted back. "I gather that you want to let your flat while you're away."

I couldn't bring myself, in front of such an audience (MH. - B. Б.), to put the matter less delicately. I hoped that Sadie would pick it up with tact.

Sadie's response was even more amiable than I had bargained for.

"My dear boy," she said, "don't speak of letting. I want a caretaker, in fact I want a bodyguard - and you can take on from now if you like."

"Well, I'd be very glad," I said. "The lease of my present place has just expired and I'm pretty well on the streets."

"Then, my dear, you must come at once," roared Sadie. "You'll be most enormously useful if you can just be around the place a little. You see, I'm being persecuted by the most frightful man."

This sounded interesting. I could feel the ears (MH. - B. Б.) being pricked up all round us. I laughed in a masculine way.

"Well, I suppose I'm fairly tough," I said. "I don't mind keeping an eye on things, provided I can get some work done too." $<\ldots>$

"My dear, it's an enormous flat," said Sadie. "You can have a suite of rooms. I'll just feel so much safer if you can come and stay there till I go away. This fellow is quite madly in love with me. He keeps calling and trying to get in at all hours, and when he doesn't call he rings up, and I'm just a nervous wreck."

"You won't start being afraid of me, I suppose?" I said, leering at her in the glass.

Sadie went off into peals of laughter. "Jake, darling, no, you're just too utterly harmless!" she called out.

I didn't so much care for this turn in the conversation. Out of the corner of my eye I could see several elegantly dressed women (MH. - - В.Б.) craning their necks to get a look at me. I felt we should change the subject.

"Who is this intolerable person?" I asked.

"I'm afraid it's the big chief himself, it's Belfounder," said Sadie. "So you can just imagine how embarrassing it all is. I'm simply beside myself." " <.. >

"Are you sure?" I said to Sadie.

"My sweet boy, I know my own boss," said Sadie.

"I mean, sure that he loves you," I said.

"He's absolutely demented about me," said Sadie. "By the way," she said, "how did you know I wanted a caretaker?"

"Anna told me," I said. I was beyond caution now.

$<\ldots>$

"Well, you call on me next Tuesday, early," said Sadie, "and I'll install you. I mean it about this bodyguard act."

"That'll be splendid, Sadie dear," I said automatically, "I'll be sure to come." And I rose. "I have to see my publisher," I explained.

Как пишет далее автор романа, Джейк $\left(\mathrm{AЧT}_{1}\right)$ и Сэди $\left(\mathrm{AЧT}_{2}\right)$ «обменялись ульбками» - “exchanged smiles", и Джейк «замагал к двери, провожаемый множеством восхищзенных женских глаз (МН. - В. Б.)» - "strode out of the place, followed by a large number offascinated female eyes” (жирный курсив наш. — В. Б.) [Murdoch, 2019, p. 56-60].

С лингвистической точки зрения можем отметить, что и Джейк, и Сэди (АЧТ) рады этой встрече. Это подтверждают авторские ремарки и невербальные средства коммуникации, подчеркивающие их хорошее отношение друг к другу и истинное чувство радости 
(«в моей радостной ульбке не было ни капли притворства», «мы улыбались друг другу в зеркале», «я невольно положил руку на ее плечо», «она одарила меня обольстительной ульбккой», «Сэди хохотала долго и звонко»), обращения АЧТ друг к другу в процессе всего диалога (Сэди: «Золото мое!», «Дуся ты мой!», «миленький», «Дорогой мой»; Джейк: «моя дорогая») и, конечно же, сам тон этого диалога, реплики и комплименты Джейка и Сэди в адрес друг друга (Сэди: «Tы всегда был такой умный, Джеейк!», «Ты как-нибудь заходи выпить ко мне домой», «Тогда переезжай немедленно!», "Ты меня страшно выручишь...», «Можешь занять хоть четыре комнаты», «...мне будет спокойнее, если ты поживешь там до моего отъезда»; Джейк: «Когда ты могла бы со мной пообедать, Сэди?», «Ну, кулаки-то у меня крепкие. Я сумею навести в этом доме порядок», «С восторгом, моя дорогая, <...> Приду непременно»).

Обращает на себя внимание тот факт, что за всем происходящим в дамской парикмахерской наблюдают мастера и клиенты, то есть эксплицитные $\mathrm{MH}$, которые то способствуют процессу данного акта коммуникации (развитию триадного диалога), то мешают его продолжению, создавая своим присутствием психологический барьер.

Интересно также отметить, что в процессе общения Джейка и Сэди (АЧТ) эксплицитных МН в лице мастеров и клиентов замечает один из АЧТ, Джейк, и, если в начале диалога они, оставаясь заинтересованными молчащими слушателями, способствуют продолжению разговора Джейка и Сэди, то в конце акта коммуникации присутствие ЭМН заставляет Джейка сначала говорить, понизив голос, затем и вообще сменить тему разговора. Теперь Джейк и Сэди (АЧТ) говорят не о себе, своих делах и своей жизни, а о другом человеке - «невыносимой личности», «самом шефе, Хьюго Белфаундере», который, по словам Сэди, «влюблен в нее до потери сознания» и преследует ее.

В анализируемом дискурсе терциарной речи включенный в триаду эксплицитный МН представлен группой людей (мастера и клиенты).

Представляется интересным в лингвистическом плане указать языковые средства обозначения МН и их реакцию на диалог АЧТ. Действия и реакция МН на услышанное в тексте анализируемого триадного диалога обозначены такими словосочетаниями и предложениями, как «все уши жадно впитывают разговор», «столь многочисленная публика», «окружавшие нас уши навострились», «несколько нарядных женщин вытянули шею, стараясь меня разглядеть», «провожаемый множеством восхищенных женских глаз». Как видим, все эти словосочетания содержат в себе существительные либо во множественном числе (уши, женщины, глаза), либо собирательные существительные в единственном числе (публика), подразумевающие группу людей, то есть МН. А состояние МН и все их действия подчеркивают высокую степень их заинтересованности в разговоре двух АЧТ в лице Джейка и Сэди. Схема данной триады представлена на рисунке 4.

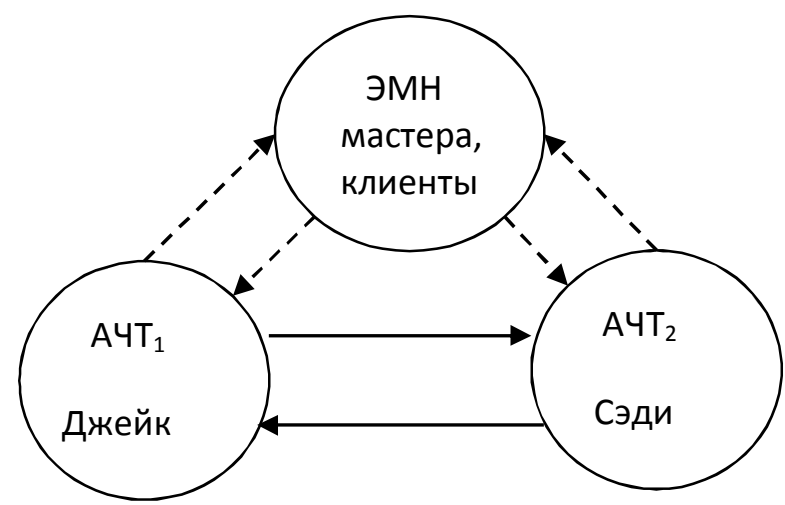

Puc. 4. Схема триады из романа «Под сетью» А. Мердок 
Следует отметить, что эксплицитный МН в лице мастеров и клиентов парикмахерской, где ведут диалог Сэди и Джейка, несомненно, влияет на обоих АЧТ и является значительной стороной триады.

В настоящем диалогическом пространстве терциарной речи альянс не наблюдается.

\section{Выводы}

Таким образом, можно сделать вывод, что анализ приведенных в настоящей работе моделей диалогов с «кодовым переключением» и полной или частичной сменой темы разговора подтверждает идею о том, что именно присутствие нежелательного для коммуникантов молчащего третьего лица (MH) при их разговоре заставляет общающихся переходить на другой язык (включая, например, язык научного общения, непонятный для ребенка) или полностью (частично) менять тему разговора. Иначе говоря, в проанализированных русско- и англоязычных диалогах присутствие третьего молчащего лица (MH) вызывает и инициирует исследуемые в работе явления «переключения кодов» и смены темы разговора. Поведение и реакции коммуникантов и молчащего наблюдателя в каждом диалоге терциарной речи различны. Разнообразны социально-психологические характеристики участников триадного диалога и коммуникативно-речевые ситуации, в которых АЧТ создают свой диалог. Различны и разнообразны и взаимоотношения как самих общающихся в каждой коммуникативно-речевой ситуации, так и их отношение к присутствующему при их разговоре МН. Важно отметить, что во всех исследованных триадных диалогах МН является неотъемлемым и влиятельным участником терциарной речи и ведет себя в них по-разному. Именно присутствие и поведение МН влияет на формирование особой коммуникативной ситуации, в которой коммуникантам приходится переключаться на другой язык, менять тему разговора и продолжать триадный диалог. Учет присутствия МН в диалоге двух коммуникантов позволяет иначе, по-новому взглянуть на двустороннее речевое взаимодействие партнеров по общению (АЧТ), оценить универсальные и специфические характеристики диалогического дискурса терциарной речи, которые довольно трудно определить при анализе диалога без учета роли молчащего третьего лица (МН).

\section{Список источников}

1. Бабаян В. Н. Лакуны в триаде (диалог с молчащим наблюдателем /MH/) // Вопросы психолингвистики. - М., 2006. - № 3. - С. 168-182.

2. Бабаян В. Н. Психолингвистические особенности диалогического дискурса терциарной речи в присутствии эксплицитного молчащего третьего лица // Иностранные языки в высшей школе. - Рязань, 2016. - Вып. 4 (39). - С. 25-33.

3. Борботько В. Г. Принципы формирования дискурса: от психолингвистики к лингвосинергетике. - М. : Либроком, 2006. - 288 с.

4. Денисов К. М. Терминология когнитивной парадигмы англоязычного политического дискурса // Теория и практика иностранного языка в высшей школе. - 2012. - № 8. - С. 9-16.

5. Карасик В. И. Язык социального статуса. - М. : Гнозис, 2002. - 333 с.

6. Куприн А. И. Слон // Собр. соч. : в 5 т. - Т. 3 : Рассказы. 1906-1913. - М. : Правда, 1982. - C. $145-148$.

7. Макаров М. Л. Основы теории дискурса. - М. : Гнозис, 2003. - 280 с.

8. Мельникова К. А. Дискурс с точки зрения корпусной лингвистики // Лингводидактика в неязыковом вузе: традиционные и инновационные подходы : сб. науч. ст. по материалам Междунар. науч.-практ. конф. — Ярославль : Изд-во Ярославл. гос. техн. ун-т, 2019. - С. 94-99.

9. Орлова Н. О. К вопросу о военном дискурсе как особом типе институционального дискурса // Антропоцентрическая направленность лингвистических исследований поликультурного военного и политического дискурса : коллективн. моногр. / под науч. ред. В. Н. Бабаяна. - Ярославль : Цифровая типография, 2020. - С. 27-36. 
10. Орлова Н. О., Богданова О. Ю., Крамаренко О. Л. Основные компоненты военного дискурса как особого типа институционального дискурса // Казанская наука. - 2020. - № 11. C. $161-163$.

11. Чиршева Г. Н. Введение в онтобилингвологию : моногр. - Череповец : Череповецк. гос. ун-т, 2000. - $194 \mathrm{c}$.

12. Cronin A. J. The Citadel. — Moscow : Higher School Publishing House, 1966. - 515 p.

13. Crystal D. The Cambridge Encyclopedia of Language. - Cambridge : Cambridge University Press, 1987. $-480 \mathrm{p}$.

14. Crystal D. The Cambridge Encyclopedia of the English Language. - Cambridge : Cambridge University Press, 2005. - 499 p.

15. Dijk T. A. van. Discourse, power and access // Texts and Practices. Readings in Critical Discourse Analysis / Ed. C. R. Caldas-Coulthard, M. Coulthard. — London ; N.Y. : Routledge, 1996. — Pp. 84-104.

16. Fromkin V., Rodman R. An Introduction to Language. Fourth Edition. - Los Angeles : University of California ; Raleigh : North Carolina State University. Holt, Rinehart and Winston, Inc., 1988. - $474 \mathrm{p}$.

17. Garnham A. Psycholinguistics. Central Topics. — London; New York, 1994. - 269 p.

18. Murdoch I. Under the Net. — London : Vintage Classics, 2019. — 296 p.

\section{References}

1. Babajan V. N. Lacunae in a Triad (dialogue in the presence of a silent bystander). Voprosy psiholingvistiki [Issues of Psycholinguistics]. Moscow, 2006, no. 3, pp. 168-182. (In Russian).

2. Babajan V. N. Psycholinguistic Features of a Tertiary Dialogical Discourse in the Presence of an Explicit Silent Bystander. Inostrannyje jazyki v vysshej shkole [Foreign Languages in Tertiary Education]. Ryazan', 2016, iss. 4 (39), pp. 25-33. (In Russian).

3. Borbotko V. G. Principy formirovanija diskursa: ot psiholingvistiki $k$ lingvosinergetike [Discourse formation principles: from Psycholinguistics to Linguasynergetics]. Moscow, 2006, $288 \mathrm{p}$. (In Russian).

4. Denisov K. M. English political discourse cognitive terminology paradigm. Teoria i praktika inostrannogo yazyka $v$ vysshei shkole [Theory and practice of a foreign language in higher school]. 2012, no. 8, pp. 9-16. (In Russian).

5. Karasik V. I. Jazyk social'nogo statusa [The language of social status]. Moscow, Gnozis, 2002, 333 p. (In Russian).

6. Kuprin A. I. The Elephant. Sobranie sochineniy [Collection]. In 5 vol. Vol. 3. Moscow, 1982, pp. 145-148. (In Russian).

7. Makarov M. L. Osnovy teorii diskursa [Discourse Theory Basics]. Moscow, Gnozis, 2003, 280 p. (In Russian).

8. Melnikova K. A. Discourse through corpus linguistics point of view. Lingvodidaktika v neyazykovom vuze: traditsionnye i innovatsionnye podhody [Linguadidactics in non-language higher educational institution: traditional and innovative approaches]. Collection of scientific works of International research and practical conference. Yaroslavl, 2019, pp. 94-99. (In Russian).

9. Orlova N. O. On the military discourse as a special type of the institutional discourse. (Red. V. N. Babayan) Antropocentricheskaya napravlennost lingvisticheskih issledovaniy polikulturnogo voennogo $i$ politicheskogo diskursa [Anthropological approach to poly-cultural military and political discourse linguistic research]. Yaroslavl, Yaroslavl Higher Military Institute of the Air Defense. 2020, pp. 27-36. (In Russian).

10. Orlova N. O., Bogdanova O. Yu., Kramarenko O. L. Principal components of military discourse as a special type of institutional discourse. Kazanskaya nauka [Kazan science]. 2020, no. 11, pp. 161-163. (In Russian).

11. Chirsheva G. N. Vvedenie v ontobilingvologiu [Introduction to Ontobilinguology]. Cherepovets, 2000, 86 p. (In Russian).

12. Cronin A. J. The Citadel. Moscow, Higher School Publishing House, 1966, 515 p.

13. Crystal D. The Cambridge Encyclopedia of Language. Cambridge, Cambridge University Press, 1987, $480 \mathrm{p}$. 
14. Crystal D. The Cambridge Encyclopedia of the English Language. Cambridge, Cambridge University Press, 2005, 499 p.

15. Dijk T. A. van. Discourse, power and access. (Ed. C. R. Caldas-Coulthard, M. Coulthard). Texts and Practices. Readings in Critical Discourse Analysis. London, N.Y., Routledge, 1996, pp. 84-104.

16. Fromkin V., Rodman R. An Introduction to Language. Fourth Edition. Los Angeles, University of California, Raleigh, North Carolina State University. Holt, Rinehart and Winston, Inc., 1988, 474 p.

17. Garnham A. Psycholinguistics. Central Topics. London, New York, 1994, 269 p.

18. Murdoch I. Under the Net. London, Vintage Classics, 2019, 296 p.

\section{Информация об авторе}

Бабаян Владимир Николаевич - доктор филологических наук, доцент, профессор кафедры иностранных языков Ярославского высшего военного училища противовоздушной обороны. Тел.: +79201188172.

\section{Information about the author}

Babayan, Vladimir - Doctor of Philology, Associate Professor, Professor of the Foreign Languages Department, Yaroslavl Higher Air Defence Military College. Tel.: +79201188172.

Статья поступила в редакичию 18.04.2021;

одобрена после рецензирования 25.04.2021;

принята к публикации 25.04.2021.

Submitted 18.04.2021;

approved after reviewing 25.04.2021;

accepted for publication 25.04.2021. 
Иностранные языки в высшей школе. 2021. № 2 (57). С. 79-86.

Foreign Languages in Tertiary Education. 2021;2(57):79-86.

Научная статья

УДК 811.112 .2

DOI: 10.37724/RSU.2021.57.2.007

\title{
Стилизация устной немецкой речи в современном медийном дискурсе
}

\author{
Елена Александровна Калашникова ${ }^{1}$, \\ Галина Александровна Соколова ${ }^{2}$, \\ Дмитрий Александрович Зимарин ${ }^{3}$ \\ 1,2,3 Московский государственный лингвистический университет, Москва, Россия \\ 1 elk99@mail.ru \\ 2 ga.sokolova@mail.ru \\ 3 live25@yandex.ru
}

Аннотация. В рамках медиариторики в фокусе внимания исследователей оказываются жанры устной коммуникации, передаваемой электронно-техническими средствами. Рассматриваются вопросы стилизации устной спонтанной немецкой речи на сегментном уровне в двух жанрах медийного дискурса - ток-шоу и телесериалах. Авторы выдвигают гипотезу, согласно которой в современных немецких телесериалах и ток-шоу в сценах, имитирующих ситуации бытового общения, говорящие реализуют вариант нормы со сниженным (телесериалы), а также высоким и средним (ток-шоу) артикуляционным напряжением в зависимости от коммуникативно значимого фактора. Данные перцептивно-слухового анализа подтверждают выдвинутые положения.

Ключевые слова: медиариторика, медийный дискурс, литературная норма, вариативность, устная речь, телесериал, ток-шоу.

Для цитирования: Калашникова Е. А., Соколова Г. А., Зимарин Д. А. Стилизация устной немецкой речи в современном медийном дискурсе // Иностранные языки в высшей школе. 2021. № 2 (57). С. 79 86. DOI: 10.37724/RSU.2021.57.2.007.

Original article

\section{Stylization of Oral German Speech in Modern Media Discourse}

\author{
Elena A. Kalashnikova ${ }^{1}$, Galina A. Sokolova ${ }^{2}$, Dmitrij A. Zimarin ${ }^{3}$ \\ ${ }^{1,2,3}$ Московский государственный лингвистический университет, \\ Москва, Россия \\ 1 elk99@mail.ru \\ 2 ga.sokolova@mail.ru \\ 3 live25@yandex.ru
}

Abstract. Within the framework of media rhetoric researchers are interested in the genres of oral communication that can be transmitted through electronic means. The article is devoted to the problem of stylization on the segmental level of oral spontaneous German speech in two genres of media discourse, namely, talk shows and TV series. The authors propose a hypothesis that in modern German TV series and talk shows imitating everyday communication the speakers use a variant of the norm with reduced articulatory tension (TV series) and also with high or medium (talk shows) articulatory tension depending on communicatively significant factors. The results of the perceptual-auditory analysis confirm the proposed hypothesis.

Key words: media rhetoric, media discourse, standard language, variability, oral speech, TV series, talk show.

(C) Калашникова Е. А., Соколова Г. А., Зимарин Д. А., 2021 
For citation: Kalashnikova E. A., Sokolova G. A., Zimarin D. A. Stylization of Oral German Speech in Modern Media Discourse. Foreign Languages in Tertiary Education. 2021; 2(57):79-86. (In Russ.). DOI: 10.37724/RSU.2021.57.2.007.

\section{Введение}

В условиях бурного развития медийной культуры устная речь и произносительная норма, в свою очередь, претерпевают изменения.

Авторитет современного медиадискурса очень высок, поскольку события, которые он перерабатывает и отражает, приобретают для массового зрителя подчас безусловный статус, формируют его картину мира.

Критическим анализом и описанием форм, процессов и продуктов устной коммуникации, передаваемой электронно-техническими средствами, то есть средствами массовой информации, занимается частный раздел риторики - медиариторика [Bose et al., 2016, p. 156].

Основная задача медиариторики заключается в том, чтобы определить, как в средствах массовой информации создаются условия для взаимодействия между участниками интеракции - ведущими, экспертами и телерадиослушателями и в каком соотношении используются вербальные, паравербальные и невербальные средства коммуникации.

Цель данной статьи состоит в том, чтобы проследить, как в медийном дискурсе отражается вариативность произносительной нормы немецкого языка и происходит ее адаптация в ситуациях, имитирующих повседневное общение.

\section{Особенности устной речи в медийном дискурсе}

Одной из основополагающих особенностей медийной устной речи считается так называемая вторичная устность (sekundäre Oralität) [Bose et al., 2016, p. 155], которая подразумевает, что речь ведущих, репортеров и актеров является подготовленной, то есть существует письменный текст, составленный сценаристами, редакторами или спичрайтерами, который затем реализуется говорящими устно, а именно наизусть или при помощи телевизионного суфлера. Исключением является речь участников ток-шоу, которые все же имеют возможность говорить спонтанно, хотя формат ток-шоу предполагает обязательный сценарий и темы беседы известны заранее.

Еще одной важной характеристикой телевизионной устной речи является «обостренная〉 взаимосвязь между неограниченной доступностью данного продукта (любой человек, имеющий радио- или телеприемник может в любой момент подключиться) и созданием иллюзии личного общения, то есть описание и обсуждение будничных и подчас очень личных событий и переживаний. У слушателя возникает впечатление создания доверительных отношений между ним и говорящим с телеэкрана или по радио. Данное псевдоприсутствие и псевдоучастие в медийном дискурсе получило название mediale Intimität [Holly, 1996, р. 247], то есть публичная приватность.

\section{Фоностилистические варианты произносительной нормы немецкого языка}

Как известно, образцом произношения долгие годы являлся театр, точнее речь театральных актеров. Однако в 1950-е годы эта роль перешла к дикторам радио- и теленовостей [Duden, 2005]. В течение семидесяти лет речь дикторов, ведущих радио- и телепередач формирует представление о произносительной норме.

В современных исследованиях, посвященных анализу немецкого произношения (Standardaussprache), выделяется основное свойство литературной нормы немецкого языка - ее вариативность, то есть норма не рассматривается больше как единый и единственно возможный вариант, а отступления от ее реализации как «факты некодифицированного произношения вне понимания орфоэпии» [Петренко А. Д., Петренко Д. А, 2014, с. 151]. 
В рамках актуальной кодификации немецкой орфоэпической нормы немецкого языка, зафиксированной в Словаре немецкого произношения [DAWB, 2009], различают, условно говоря, три варианта произношения - с очень высоким, средним-высоким и сниженным артикуляционным напряжением. Речь идет о фоностилистических вариантах произносительной нормы, которые характеризуются различной полнотой реализации звуков, и их употребление варьируется в зависимости от сферы общения и условий коммуникации. Данный подход к описанию орфоэпической нормы можно охарактеризовать как переход от моноцентризма к полицентризму [Глушак, Калашникова, 2017].

Маркерами выделяемых стилей произношения на сегментном уровне в немецком языке являются, например, наличие или отсутствие твердого приступа, степень выраженности аспирации, количественная и качественная редукция гласных, наличие разных видов ассимиляций, выпадение конечных согласных $t, l, n$, реализация редуцированного гласного [ə] в конечных слогах, аллофоны согласного $r$ в позиции перед гласным и после краткого гласного.

Таким образом, в руках исследователей звучащей речи появился определенный эталон, позволяющий определить, какой вариант нормы использует тот или иной говорящий и насколько фонетическое оформление его речи соответствует ситуации общения.

Стоит отметить, что границы между стилями достаточно размыты, однако совокупность нескольких звуковых модификаций (ослабление твердого приступа, качественные и количественные редукции гласных в служебных и знаменательных словах, тотальные ассимиляции, выпадение конечных и серединных согласных, снижение аспирационного напряжения) является основанием для отнесения анализируемых фрагментов речи к определенному варианту нормы.

Итак, основной характеристикой устной нормы является ее естественность в соответствующей коммуникативной ситуации. Представим себе «разговор по душам» на кухне с чрезмерной артикуляционной четкостью и громкостью. Безусловно, данный вариант будет звучать неестественно и неуместно. Говорящий вольно или невольно подстраивается под ситуацию общения и интуитивно реализует адекватный вариант произношения.

\section{Жанры медийного дискурса}

Пожалуй, самыми любимыми и востребованными жанрами медийного дискурса являются телевизионные сериалы и ток-шоу.

Остановимся на отличиях телевизионных сериалов, столь полюбившихся зрителям по всему миру, от кинофильмов.

Формат телевизионного сериала отличается от полного метра уже тем, что сам телеэкран меньше, а зритель находится соответственно ближе к экрану, что создает ощущение более интимного и доверительного пространства между зрителем и актерами, иногда даже стирая эту грань. Часто это проявляется в том, что актеров телесериалов отождествляют с их героями и считают «своими», вхожими в семью.

Отсутствие существенной дистанции между актером и зрителем работает как экстралингвистический фактор и влияет, в свою очередь, на реализацию коммуникативных средств. Перед телевизионными актерами стоят другие задачи, что приводит, как считается, к редукции невербальных средств выразительности. Интересен факт, что в 1950-е годы, когда телеиндустрия начала активно развиваться, востребованными стали так называемые «тихие» актеры. В конце 1960-х на первый план выходит так называемый Alltagsdarsteller актер, который близок каждому, «сосед» из реальной жизни, имеющий неброскую внешность и говорящий естественно в бытовых игровых сценах [Hickethier, 2012, p. 177].

Тем не менее в 1970-х годах, как отмечает немецкий исследователь кино и телевидения Кнут Хикетье, встраивание героя в ситуацию повседневного общения не означает, что актеры говорят так же, как в жизни, то есть полностью перенося в кадр естественный вариант фонетической нормы, свойственный ситуациям повседневного общения [Hickethier, 2012, p. 177]. 
Изображение ситуаций повседневного общения в телевизионном формате не означает, что в сериалах актеры полностью адаптируют свою речь и выбирают вариант нормы, который они бы использовали в аналогичной ситуации в жизни. Речь идет о некоем соответствии речи актеров нашим ожиданиям и представлениям о естественной речи в ситуациях повседневного общения. Эти представления закреплены в сознании у носителей языка и формируются в том числе и самими средствами массовой информации. Они могут намеренно нарушаться с целью выделения каких-то специфических черт, подчеркивая самобытность и индивидуальность героя.

Наблюдая за современным телевидением, нельзя не отметить, что в последние годы в различных жанрах и форматах передач делается акцент на сближение ведущего и гостей в студии. Данная тенденция особенно явно проявляется в формате ток-шоу.

Современные ток-шоу отличаются большим жанровым разнообразием. Тем не менее классическое ток-шоу представляет собой треугольник: ведущие, гости (эксперты) и зрители в студии, где основная роль отводится ведущим и приглашенным гостям-экспертам. Зрители, как правило, наблюдают за дискуссией и не принимают участия в обсуждении, создавая определенный фон, подтверждающий публичность ситуации. Основным жанрообразующим признаком данного телевизионного формата является вопросно-ответная структура, напоминающая беседу, дискуссию или интервью [Вакурова, Московкин, 1997].

Таким образом, мы можем наблюдать на телеэкране тенденцию к стиранию границ между ведущими и гостями студии. На всех каналах можно увидеть примеры ток-шоу, где в студии воссоздается совершенно домашняя обстановка: участники погружаются в привычные всем ситуации бытового общения и чувствуют себя соответственно расслабленно и непринужденно (разговоры на кухне, на диване у камина, в гостиной комнате за чашкой чая или бокалом шампанского). Ситуации повседневного общения переносятся на телеэкран, но при этом дружеские и доверительные беседы представлены на суд как зрителям в студии, так и массовой аудитории, что приводит к возникновению упомянутой выше так называемой «публичной приватности».

Возникает вопрос: как говорящий адаптирует свою речь к такой искусственно созданной ситуации повседневного общения на телеэкране?

\section{Подготовка и проведение перцептивно-слухового анализа}

Цель проведенного исследования состояла в определении и сопоставлении уровня стилизации обиходного стиля устной немецкой речи в двух жанрах медийного дискурса ток-шоу и телесериалах. Анализ был проведен на материале немецкого телевизионного ток-шоу NDR Talk-Show и известного немецкого криминального телесериала «Место преступления» (“Tatort"). В сериале «Место преступления» каждая серия представляет собой законченную историю, а персонажи, кроме главных героев, меняются от серии к серии.

Аудиокорпус исследования составили образцы речи популярного немецкого актера Вотана Мильке Меринга в серии «Смертельный прилив» (“Tödliche Flut”) в эпизодах непринужденного общения ${ }^{1}$ ) и его выступление на северогерманском телеканале NDR (Norddeutscher Rundfunk) в NDR-Talkshow в гостях у ведущих Барбары Шенебергер и Хубертуса Мейер-Буркхардта, где в студии также имитируется непринужденная обстановка - гости располагаются в удобных креслах за накрытым столом с бокалами шампанского 2 .

В исследовании устно-речевой коммуникации для достижения достоверных результатов очень важно выявить действительно коммуникативно значимые факторы, влияющие на речевое оформление. Ведущим фактором, оказывающим влияние на оформление речи

${ }^{1}$ URL: https://www.daserste.de/unterhaltung/krimi/tatort/videos/toedliche-flut-video-110.html (дата обращения: 09.04.2021).

${ }^{2}$ URL: https://youtu.be/xIh7z_I6bZw (дата обращения: 09.04.2021). 
Вотана Мильке Меринга в телесериале, оказывается заложенная в актерской игре вторичная yстность, то есть актер воспроизводит написанный для сценария текст, и его речь соответственно можно охарактеризовать как «квазиспонтанную». Его же речь в NDR-Talkshow можно считать спонтанной, так как актер, отвечая на вопросы ведущих и поддерживая общую беседу, не имеет исходного текста, и процесс планирования и продуцирования речи осуществляется параллельно, что является главным условием спонтанности. Ведущим коммуникативно значимым фактором, оказывающим влияние на оформление его речи в ток-шоу, становится публичная приватность.

Авторами были выдвинуты две гипотезы:

1. Речь актеров, стилизованная под спонтанную в ситуациях повседневного общения в современных немецких телесериалах, реализуется в рамках нормы со сниженной степенью артикуляционной четкости.

2. В ток-шоу в воссозданной ситуации непринужденного общения, где существенным является фактор публичной приватности, ожидается увеличение степени артикуляционного напряжения и соответственно реализация варианта нормы со средней и высокой артикуляционной четкостью.

Сопоставительный перцептивно-слуховой анализ был проведен на сегментном уровне по следующим звуковым индикаторам:

1) В рамках вокализма:

- реализация/отсутствие твердого приступа гласного в начале слов;

- качественная редукция гласных (наличие слабых форм);

- реализация/выпадение редуцированного гласного [ә] в конечном слоге -en.

2) В рамках консонантизма:

- реализация/ослабление аспирации;

- реализация/выпадение конечных согласных $t, l, n$.

\section{Результаты перцептивно-слухового исследования}

В сериале "Тӧdliche Flut" по результатам проведенного анализа речи Вотана Мильке Меринга были получены следующие данные:

Эпизод 1. Разговор со свидетелем. Место съемки: кафе.

В рамках вокализма:

- отсутствие твердого приступа гласного в начале слов: Imke [imkə] alles ['aləs],

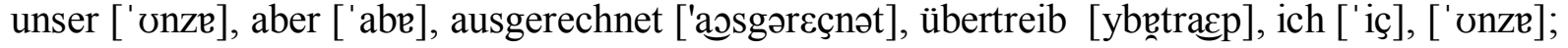

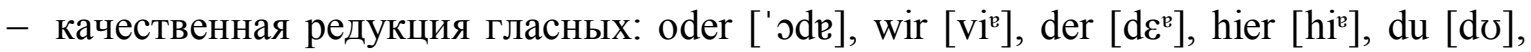
$\operatorname{dir}\left[\mathrm{di}^{\mathrm{b}}\right]$, wir [ $\left.\mathrm{vi}^{\mathrm{i}}\right]$ haben ['habm], spätestens ['Jpetəstṇs];

- выпадение редуцированного гласного [ә] в конечном слоге -en: gehen [ge:n], haben ['habm], zusammen [tsu'zam], können ['kœn].

В рамках консонантизма:

- отсутствие или ослабление аспирации смычно-взрывных согласных $p, t, k$ : Polizei [poli'tsa $\varepsilon$ ], Kollegen [ko'le:gn], kann [kan], tut [tut];

- выпадение конечных согласных $t$, $l$ : ist [Is], und [on], mal [ma].

Эпизод 2. Разговор со свидетелем. Место съемки: зал в Доме культуры.

В рамках вокализма:

- отсутствие твердого приступа гласного в начале слов: es [əs], Insel ['inzl], ermordet

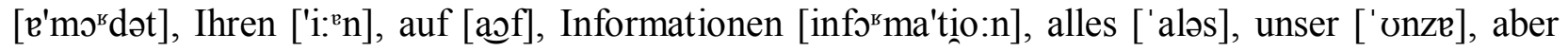
['abe], ausgerechnet ['aəssgəreçnət], ich ['iç], ['vnze];

- качественная редукция гласных: oder ['odv], wir [vi $\left.\mathrm{vi}^{\mathrm{p}}\right]$, der $\left[\mathrm{d} \varepsilon^{\mathrm{p}}\right]$, hier [hip $\mathrm{i}^{\mathrm{p}} \mathrm{du}[\mathrm{dv}]$, $\operatorname{dir}\left[\mathrm{di}^{\mathrm{p}}\right]$, wir $\left[\mathrm{vi}^{\mathrm{k}}\right]$, haben ['habm];

- выпадение редуцированного гласного [ə] в конечном слоге -en: Namen ['na:mn], Stimmenkauf ['ftimņkąof], weitergeben ['wąctrgebm]]. 
В рамках консонантизма:

- отсутствие или ослабление аспирации смычно-взрывных согласных $p$, $t, k$ : Property ['prope $\varepsilon^{\text {sti] }}$, Korruption [koruptsi'o:n], konnte ['kontə];

- выпадение конечных согласных $t$, $l$ : ist [Is], und [on], mal [ma].

Таким образом, мы видим, что в речи актера преобладают слабые формы слов, твердый приступ гласных реализуется в единичных случаях, аспирация смычно-взрывных согласных $p, t, k$ ослаблена, редуцированный гласный в конечном слоге -еn выпадает во всех позициях, конечные согласные $t, l$ также выпадают в часто употребляемых словах $n i c h t$, ist, mal jetzt. Соответственно можно сделать вывод, что реализация индикаторов сегментного уровня типична для варианта нормы со сниженным артикуляционным напряжением.

Ток-шоу. По результатам проведенного анализа речи Вотана Мильке Меринга на северогерманском телеканале NDR в NDR-Talkshow были получены следующие данные:

В рамках вокализма:

- наличие твердого приступа гласного в начале слов: es[рєs], Ankunft [rankunft] [?onze], ankommt [rankomt], Indianer ['rindi'a:ne], aber ['rabe], Ausstattung ['ravsstatun], Abenteuer

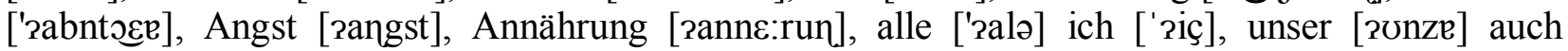

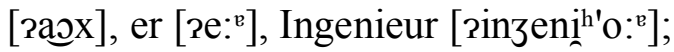

- качественная редукция гласных: oder ['ode], wir [vi $\left.{ }^{\mathfrak{p}}\right]$, der $\left[\mathrm{d} \varepsilon^{\mathrm{v}}\right]$, hier $\left[\mathrm{hi}^{\mathrm{p}}\right], \mathrm{du}[\mathrm{d} v]$, $\operatorname{dir}\left[\mathrm{di}^{\mathrm{e}}\right]$, wir $\left[\mathrm{vi}^{\mathrm{e}}\right]$ haben ['habm];

- выпадение редуцированного гласного [ə] в конечном слоге -en: gehen [ge:n], haben ['habm], zusammen [tsu'zam], können ['kœn], transportieren [transposti: ${ }^{\mathrm{n}} \mathrm{n}$ ], fallen [faln].

В рамках консонантизма:

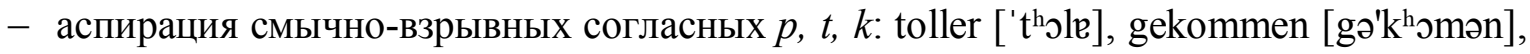
kennen [ $\left.\mathrm{k}^{\mathrm{h}} \varepsilon \mathrm{n}\right]$, ankommt ['ank $\left.{ }^{\mathrm{h}} \curvearrowright \mathrm{mt}\right]$, kennenlernst ['k ${ }^{\mathrm{h}} \varepsilon$ nlernst], Kontakt [kon't $\left.\mathrm{t}^{\mathrm{h}} \mathrm{akt}\right]$;

- выпадение конечных согласных $t$, $l$ : ist [Is], und [ชn] nicht [niç], mal [ma].

В речи Вотана Мильке Меринга преобладает вариант нормы со средней и высокой степенью артикуляционного напряжения, так как актер в большинстве случаев реализует полные формы слов, твердый приступ гласных в начале слов и аспирацию смычно-взрывных согласных $<p, t, k>$ в акцентно выделенных словах. В то же время можно наблюдать выпадение конечных согласных $<t, l>$, количественную и качественную редукцию гласных в местоимениях и служебных словах. В одном случае было также зафиксировано явление фрикатизации смычно-взрывного согласного $<g>$ в интервокальной позиции sage [za: әә] Данные явления на сегментном уровне характерны в целом для устной речи и подтверждают ее спонтанность.

\section{Заключение}

Проведенный перцептивно-слуховой анализ произношения актера Вотана Мильке Меринга в роли комиссара Торстена Фальке в фильме "Tödliche Flut" и его произношения на северогерманском телеканале NDR в NDR-Talkshow позволили осуществить фоностилистическую интерпретацию полученных данных в рамках современной орфоэпической нормы немецкого языка и прийти к следующим выводам:

1. Фоностилистические варианты нормы современного немецкого языка находят свое отражение в медийном дискурсе и представлены, в частности, в телесериалах в сценах непринужденного и доверительного общения и в ток-шоу.

2. Стилизация обиходного стиля устной немецкой речи в современных немецких телесериалах проявляется в сниженной степени артикуляционного напряжения и тем самым адекватно отражает ситуацию повседневного общения по сравнению с телесериалами 1970-1980-х годов.

3. В сравнении с телесериалом речь актеров в ток-шоу характеризуется большей артикуляционной напряженностью, что обусловлено публичностью коммуникации, то есть фактор публичности превалирует над приватностью. 
Таким образом, обе выдвинутые гипотезы нашли свое подтверждение.

В целом стоит отметить, что современная орфоэпическая норма немецкого языка обнаруживает тенденцию к размягчению, то есть к либерализации, и что фоностилистическая реализация обиходного стиля речи вытесняет формы нейтрального стиля, в современной трактовке - варианта нормы со средней и высокой артикуляционной четкостью, ранее свойственной медийному дискурсу.

В связи с тем что современная норма языка во многом формируется средствами массовой информации, задачи медиариторики видятся нам среди прочего в том, чтобы не только фиксировать происходящие в устной речи изменения, но и уделять больше внимания культуре устной речи дикторов и всех участников коммуникации в многообразной палитре жанров медийного дискурса.

\section{Список источников}

1. Глушак В. М., Калашникова Е. А. Подходы к кодификации немецкого произношения в диахроническом аспекте // Вестник Тверского государственного университета. Сер.: Филология. 2017. 一 № 2. - C. 86-89.

2. Вакурова Н. В., Московкин Л. И. Типология жанров современной экранной продукции. М. : Ин-т совр. искусства, 1997. - 62 с.

3. Петренко А. Д., Петренко Д. А. Социофонетические аспекты языковой вариативности // Известия Южного федерального университета. Филологические науки. — 2017. — № 4. - С. 150-160.

4. Bose I., Hirschfeld U., Neuber B., Stock E. Einführung in die Sprechwissenschaft. — 2. Aufl. Tübingen : Narr Studienbücher, 2016. - 290 p.

5. DUDEN : Aussprachewörterbuch. - 6 Aufl. - Bd. 6. - Mannheim : Dudenverlag, 2005. $860 \mathrm{p}$.

6. Hickethier K. Film- und Fernsehanalyse. - 5 Aufl. - Weimar : J. B. Metzler Stuttgart, 2012. $-247 \mathrm{p}$.

7. Holly W. Stichwort Fernsehrhetorik // Historisches Wörterbuch der Rhetorik. - Bd. 3. - Tübingen : G. Ueding, 1996. - Pp. 243-257.

8. Krech E. M., Stock E., Hirschfeld U., Anders L. Deutsches Aussprachewörterbuch. - Berlin : Walter De Gruyter, 2009. — 1076 p.

\section{References}

1. Glushak V. M., Kalashnikova E. A. Approaches to the codification of german pronunciation in diachrony. Vestnik Tverskogo gosudarstvennogo universiteta. Seriya: Filologiya [Vestnik of Tver State University. Series Philology]. 2017, no. 2, pp. 86-89. (In Russian).

2. Vakurova N. V., Moskovkin L. I. Tipologiya zhanrov sovremennoj ekrannoj produkcii [Typology of genres of modern screen production]. Moscow, Institut sovremennogo iskusstva Publ., 1997, 62 p. (In Russian).

3. Petrenko A. D., Petrenko D. A. Sociophonetic aspects of language varietiveness. Izvestiya Yuzhnogo federal'nogo universiteta. Filologicheskie nauki [Proceedings of the Southern Federal University. Philology]. 2017, no. 4, pp. 150-160. (In Russian).

4. Bose I., Hirschfeld U., Neuber B., Stock E. Einführung in die Sprechwissenschaft. 2. Aufl. Tübingen, Narr Studienbücher, 2016, 290 p.

5. DUDEN. Aussprachewörterbuch. Mannheim, Dudenverlag, 2005, Bd. 6, 860 p.

6. Hickethier K. Film- und Fernsehanalyse. 5 Aufl. Weimar, J. B. Metzler Stuttgart, 2012, 247 p.

7. Holly W. Stichwort Fernsehrhetorik. Historisches Wörterbuch der Rhetorik. Bd. 3. Tübingen, G. Ueding, 1996, pp. 243-257.

8. Krech E. M., Stock E., Hirschfeld U., Anders L. Deutsches Aussprachewörterbuch. Berlin, Walter De Gruyter, 2009, 1076 p. 


\section{Информация об авторах}

Калашникова Елена Александровна - кандидат филологических наук, исполняющая обязанности заведующего кафедрой фонетики немецкого языка факультета немецкого языка ФГБОУ ВО «Московский государственный лингвистический университет». Почтовый адрес (раб.): 119034, г. Москва, ул. Остоженка, 38.

Соколова Галина Александровна - кандидат филологических наук, доцент кафедры фонетики немецкого языка факультета немецкого языка ФГБОУ ВО «Московский государственный лингвистический университет». Почтовый адрес (раб.): 119034, г. Москва ул. Остоженка, 38.

Зимарин Дмитрий Александрович - кандидат филологических наук, доцент кафедры фонетики немецкого языка факультета немецкого языка ФГБОУ ВО «Московский государственный лингвистический университет». Почтовый адрес (раб.): 119034, г. Москва, ул. Остоженка, 38.

\section{Information about the authors}

Kalashnikova Elena - PhD (Philology), Associate Professor, Dpt. of German Phonetics, Faculty of the German language, Moscow State Linguistic University. Postal address: 119034, Moscow, Ostozhenka 38.

Sokolova Galina - PhD (Philology), Dpt. of German Phonetics, Faculty of the German language, Moscow State Linguistic University. Postal address: 119034, Moscow, Ostozhenka 38.

Zimarin Dmitrij - PhD (Philology), Dpt. of German Phonetics, Faculty of the German language, Moscow State Linguistic University. Postal address: 119034, Moscow, Ostozhenka 38.

Статья поступила в редакцию 14.04.2021; одобрена после рецензирования 17.04.2021; принята к публикации 17.04.2021.

Submitted 14.04.2021;

approved after reviewing 17.04.2021; accepted for publication 17.04.2021. 


\title{
РУССКАЯ КЛАССИКА И ПРОБЛЕМЫ ЕЕ ПЕРЕВОДА
}

Иностранные языки в высшей школе. 2021. № 2 (57). С. 87-98.

Foreign Languages in Tertiary Education. 2021;2(57):87-98.

Научная статья

УДК $81.25+811.581$

DOI: $10.37724 /$ RSU.2021.57.2.008

\section{Механизмы интертекстуальности и способы их передачи при переводе с русского языка на китайский язык (на примере отрывков из произведений А. П. Чехова)}

\author{
Анастасия Алексеевна Запруднова \\ Рязанский государственный университет имени С. А. Есенина, Рязань, Россия \\ mrs.zaprudnova@gmail.com
}

Аннотация. В статье интертекстуальные включения в ткани принимающего текста рассматриваются как когнитивно выделенные компоненты высказывания, неизбежно оказывающиеся в фокусе внимания адресата. В качестве основного механизма перспективизации интертекстуальных отсылок рассматривается когнитивная операция сопоставления, что позволяет автору видеть в интертекстуальных отсылках метафору. Материалом исследования служат насыщенные аллюзиями произведения А. П. Чехова. Автор классифицирует интертекстуальные включения в текстах А. П. Чехова на мифологические, библейские и литературные и оценивает возможность их сохранения при переводе на китайский язык.

Ключевые слова: интертекстуальность, интертекст, межтекстовое взаимодействие, диалогизм, вторичный текст, прецедентный текст, интертекстуальные включения, интертекстуальные отсылки, аллюзия, когнитивные операции, когнитивно выделенные компоненты высказывания, фокус и перспектива, фигура и фон, сопоставление, метафора.

Для цитирования: Запруднова А. А. Механизмы интертекстуальности и способы их передачи при переводе с русского языка на китайский язык (на примере отрывков из произведений А. П. Чехова) // Иностранные языки в высшей школе. 2021. № 2 (57). C. 87-98. DOI: 10.37724/RSU.2021.57.2.008.

Original article

\section{Mechanisms of Intertextuality and Means of Rendering Them in Translation from Russian into Chinese (illustrated by excerpts from A.Chekhov's works)}

Anastasia A. Zaprudnova

Ryazan State University named for S. A. Esenin, Ryazan, Russia mrs.zaprudnova@gmail.com

Abstract. The paper offers a comprehensive study of cognitive processes and conceptual operations underlying intertextual inclusions, which make them the figure in the ground of the receiving text, thus bringing them to the focus of the addressee's attention. The author suggests that intertextual inclusions can be viewed as metaphorical expressions due to the common mechanism of identification being the basis of the two. To make

(C) Запруднова А. А., 2021 
the research more argumentative the author analyses intertextual allusions in A. Chekov's works which serve as material for research. The studied examples are classified into allusions to mythological, bible and literary works. The author attempts to convey the meaning of the allusions under analysis into Chinese and studies the factors influencing the possibility of the translation process.

Keywords: intertextuality, intertext, intertextual interaction, dialogism, secondary text, precedent text, intertextual inclusions, allusion, cognitive operations, focus and perspective, figure and ground, identification, metaphor.

For citation: Zaprudnova A. Mechanisms of Intertextuality and Means of Rendering Them in Translation from Russian into Chinese (illustrated by excerpts from A. Chekhov's works). Foreign Languages in Tertiary Education. 2021;2(57):87-98. (In Russ.). DOI: 10.37724/RSU.2021.57.2.008.

Новый текст, как известно, формируется на предшествующей ему текстовой среде, вбирая в себя основные культурно значимые параметры, с одной стороны, и обогащаясь новыми смыслами, которые привносит в него творческая личность автора, - с другой.

Изучение межтекстовых взаимодействий и выявление их роли в выражении концептуального смысла вторичного текста на основе его связи с текстом-источником осуществляется в рамках интертекстуального подхода к исследованию текста.

Понятие интертекстуальности как одной из основных текстовых категорий было введено еще в 1967 году теоретиком постструктурализма Юлией Кристевой, однако границы термина «интертекстуальность» до сих пор не определены.

Существующие трактовки интертекстуальности можно объединить в две большие подгруппы.

В широком смысле интертекстуальность понимается как реализация в новом тексте всего культурно-исторического опыта личности - как вербального, так и невербального, накопленного как в пределах собственной, так и в отношении мировой культуры. Интертекстуальность в широком понимании изучали французские философы, представители постструктурализма Р. Барт, Ю. Кристева и др.

Однако такое рассмотрение всякого текста как интертекста «растворяет сами понятия текста и интертекстуальности» [Баженова, 2003, с. 105] и не только не позволяет выявить различные типологические формы интертекстуальности, но и ведет к исчезновению авторства и автора: "Il n'est pas de texte que d'intertexte” («Нет текста кроме интертекста» ${ }^{1}$ ). [Grivel, 1997, с. 68].

В соответствии с более узким подходом, которого придерживались Н. А. Кузьмина, И. П. Смирнов, Н. А. Фатеева, В. Е. Чернявская, М. Б. Ямпольский, под интертекстуальностью понимается «слагаемое широкого родового понятия... имеющего в виду, что смысл художественного произведения полностью или частично формулируется посредством ссылки на иной текст, который отыскивается в творчестве того же автора, в смежном искусстве, в смежном дискурсе или предшествующей литературе» [Смирнов, 1985, с. 12]. При этом не только автор намеренно и осознанно включает в свой текст фрагменты иных текстов, но и адресат верно понимает авторскую интенцию и воспринимает текст в его диалогической отнесенности. Кроме того, необходимо, чтобы между автором и читателем создавался определенный резонанс и вследствие этого понимание интертекстуальной природы произведения.

В настоящее время термин интертекстуальность рассматривается как важнейшая категориальная характеристика текста, отражающая его «разгерметизацию» и открытость другим смысловым системам, способность текста вступать в контакт с другими - предшествующими текстами, которые различные исследователи называют также прототекстами или предтекстами, а также как специфическая стратегия текстопостроения в различных сферах коммуникации [Чернявская, 2007, с. 49].

\footnotetext{
1 Здесь и далее перевод наш. - A. 3.
} 
Если интертекстуальность в лингвистике понимается как текстовая категория, отражающая соотнесенность одного текста с другим, диалогическое взаимодействие текстов в процессе их функционирования, обеспечивающее приращение смысла произведения [Баженова, 2003, с. 104], то под интертекстом понимается совокупность текстов, однородно интертекстуально маркированных. Тексты, интертекстуально однородно маркированные, это тексты, содержащие отсылки к одному и тому же источнику или друг к другу, иными словами, включающие одну пресуппозицию, то есть «акт отсылки к факту, который известен (предполагается известным) слушателю» [Ван Дейк, 1978, с. 298].

Такие однородно маркированные элементы интертекста оказываются когнитивно выделенными компонентами смысла произведения, то есть «чужое слово» (термин Бахтина) в ткани принимающего текста становится объектом фокусирования внимания адресата [Бахтин, 1979].

В психологии «организационная тенденция восприятия» была впервые описана датским гештальтпсихологом Э. Рубином, который для обозначения перцептивной связи между объектом фокусирования и остальной частью перцептивного поля предложил использовать термины фигура (figure) и фон (ground). Впоследствии термины, предложенные Э. Рубином, Л. Талми ввел в когнитивную лингвистику. Исследованию вопросов о связи языковых форм со структурами человеческого знания, процессов концептуализации и языковой репрезентации фокусировки внимания посвящены также работы Дж. Лакоффа [Lakoff, 1980], Ч. Филлмора [Филлмор, 1981], Р. Лэнекера [Langacker, 1991], Р. Тейлора [Taylor, 1995], Е. Кубряковой [Кубрякова, 2004] и др.

В случае интертекстуальных включений именно они становятся фигурой и выносятся на передний план - в фокус внимания, в то время как контекст принимающего текста воспринимается как второстепенный и, следовательно, отодвигается на задний план в качестве фона.

В этом отношении можно обратиться к Ч. Филлмору, который отмечал, что, воспринимая любое языковое выражение, человек имеет дело одновременно с фоновой сценой, которой это выражение принадлежит, и с перспективой, которая налагается на эту сцену. Выбор какого-либо конкретного выражения вызывает у воспринимающего представление о целой сцене, активизирует её в сознании реципиента, но в то же время выносит на передний план, в перспективу, какой-то конкретный аспект или участника сцены [Филлмор, 1981, с. 519]. То есть прецедентный феномен, активизируемый в сознании читателя посредством отсылки к иному тексту, ситуации, имени или высказыванию, налагается на фоновую сцену принимающего текста в качестве перспективы, вынося на передний план некоторую ее часть, при этом «перспективизация одного компонента ситуации вытесняет другие компоненты на задний план, а иногда и вовсе подавляет и скрывает их» [Taylor, 1995, с. 90].

П. Фонтаньер, описывая когнитивные аспекты интертекстуальности, упоминает еще один важный механизм, участвующий в актуализации смысла интертекстуальных включений, а именно механизм сопоставления. Он отмечает, что аллюзии «дают возможность уловить наличие связи между одной вещью, о которой говорят, с другой вещью, о которой не говорят ничего, но представление о которой возникает благодаря этой связи» [Fontanier, 1977, c. 125].

Феномен сопоставлений - естественный способ языковой организации жизненного опыта. Именуя объекты действительности (явления, процессы, свойства и т. п.), мы устанавливаем их сходство с уже известными нам классами объектов, таким образом раздвигая их границы. Сопоставление пронизывает всю языковую и концептуальную системы. Происходит это как в пределах одного признака, так и по целому набору признаков. В ходе такого сопоставления может быть установлена аналогия или выявлен контраст в отношении одного или нескольких признаков сопоставляемых объектов/явлений/процессов и т. п., а результатом становится чаще всего метафора. 
За счет механизма сопоставления реализуется сближение двух фрагментов текста явленного в тексте физически и фрагмента прецедентного текста, который присутствует у читателя в памяти. Так, благодаря механизму сопоставления, два текста становятся семантически смежными. Кроме того, вышесказанное позволяет нам видеть в интертекстуальных отсылках метафору. При этом под метафорой мы понимаем когнитивную операцию над понятиями, которая выступает как «средство концептуализации и позволяет человеку осмыслить ту или иную область действительности в терминах понятийных структур, изначально сложившихся на базе опыта, который был получен человеком в других областях» [Запруднова, 2017, с. 16].

Однако не всегда автор может быть уверен, что реципиент правильно интерпретирует то, что автор хотел сказать, ссылаясь на тот или иной текст. С точки зрения когнитивной лингвистики основу интертекстуальной компетенции реципиента составляют его когнитивные структуры. В. В. Красных определяет данные образования как неделимые и нечленимые когнитивные единицы, хранящие «свернутое» знание и/или представление [Красных, 1998, С. 65]. Когнитивные структуры подразделяются на феноменологические, представляющие собой совокупность знаний и представлений об экстралингвистических и собственно лингвистических явлениях (исторические события, реальные личности, законы природы, произведения искусства и т. п.), и лингвистические, составляющие основу языковой и речевой компетенции.

В сущности, процесс восприятия и интерпретации интертекстуальных включений базируется в большей степени на актуализации именно феноменологических когнитивных структур, активизирующих прецедентные знания и представления реципиента.

Логично заключить, что при переводе интертекстуальных включений встает ряд вопросов: хранится ли текст-источник, к которому отсылает нас автор оригинала, в активной памяти читателя перевода? не случится ли так, что прецедентный феномен ничего не скажет читателю и сможет быть обнаружен лишь эрудитами? Ведь в таком случае произойдет смена фокуса внимания и интертекстуальный элемент перейдет из центра в периферию. Как компенсировать потерю смысла, если эксплицитное обращение к тексту, к которому отсылает нас интертекст имплицитно, невозможно? Задача читателя разглядеть отсылки к прецедентному тексту и расшифровать их смысл. Задача переводчика заключается прежде всего в эксплицировании имплицитных отсылок, в выявлении тех смыслов, которые присутствуют в интертексте скрыто. Обнаружить источник - значит, по выражению Н. Пьеге-Гро, «демонтировать механизм» сопоставления, «чтобы затем с его помощью косвенным образом вписать в текст перевода требуемый смысл» [Пьеге-Гро, 2008, С. 94].

В качестве материала исследования нами используются произведения великого русского классика А. П. Чехова и их переводы на китайский язык.

Тексты А. П. Чехова - будь то реплики отдельных персонажей или целостные эпические и драматические произведения - насыщены цитатами, аллюзиями, парафразами, перекличками, реминисценциями, стилизациями, пародиями, параллелями, проекциями и т. П., что свидетельствует об интертекстуальном характере его произведений.

В ранних работах писателя обнаруживаются многочисленные интертекстуальные включения в виде цитат, аллюзий к мифологическим, библейским, литературным персонажам, историческим личностям, писателям, художникам и др.

Мифологические отсылки в произведениях А. П. Чехова служат, как правило, для создания иронической характеристики героев. При сравнении персонажей с известными образами мифологии автор часто прибегает к механизму аналогии и образует метафору, сочетая при этом слова разной стилистической окрашенности, в результате чего рождается ирония. 
Так, например, в рассказе «Тряпка», Чехов нетерпение своего героя, который вынужден стоять за дверью, потому что его не пускают на званый вечер, описывает следующим образом:

«У секретаря затрепетало под сердцем. Муки Тантала ${ }^{2}$ были ему не по силам».

Ввиду того что Тантал ${ }^{3}$ как персонаж греческой мифологии малоизвестен китайскому читателю, при сохранении аллюзии в тексте перевода она сможет быть угадана только благодаря довольно объемному пояснению, которое и приводится в сноске в издании《契诃夫小说全集》(《Полное собрание коротких рассказов А. П. Чехова»):

《秘书心口底下发颤。他可经不住坦塔罗斯(4)的磨难埃。

（4）希腊神话中吕底亚的国王，因触犯主神宙斯而受罚，站在齐颈的水中，头上悬有 果子, 但他要喝水时, 水就退去, 他要吃果子时, 果子就上升离去, 因此永远又饥又渴。》

Нам представляется возможным компенсировать разрыв текста и, наряду с аллитерацией, использовать описательный перевод, который позволит не имплицитно, а эксплицитно выразить признак аналогии.

Наи перевод:

《秘书心里点态的等待。到这儿就好像坦塔洛斯因得罪众神被罚到了冥土永受饥渴

之苦。而该磨难他受不了。»

Подстрочник:

«Сердце секретаря трепетало в ожидании. Он стоял там (за дверью), словно Taнmaл, наказанный за оскорбление богов, сосланный в загробный мир и обреченный на вечные муки голода и жажды. Эти мучения были невыносимы» (здесь и далее по тексту перевод наш. - A. 3.)

В «Скуке жизни» генерал-самодур в споре с женой использует фразу:

«Ю口итер, ты сердишься, значит, ты не прав» ${ }^{4}$.

Автор перевода вновь прибегает к пояснениям с помощью ссылок:

《朱庇特 (7)呀，你生气了，那么可见你不对。哈哈。

(7) 古罗马神话中最高的神, 即希腊神话中的宙斯。》

В данном случае нам представляется возможным замена механизма аналогии с имплицитного на эксплицитный и использование сравнения вместо метафоры. При этом мы усиливаем комический эффект, расширяя метафору, и вводим обращение «моя царица» (по аналогии с «Юпитер — царь богов»).

Наш перевод:

《我的女王，你似朱庇特要是生气，就意味着你错了。»

${ }^{2}$ В приведенных примерах из произведений А. П. Чехова аллюзии и их перевод выделены нами. - $A .3$.

${ }^{3}$ В греческой мифологии Тантал, царь Фригии (называемый также царем Лидии), был любимцем богов, которые часто приглашали его на свои пиршества. Но, возгордившись своим положением, он оскорбил богов, за что и был жестоко наказан. По Гомеру («Одиссея», 11, 582-592), наказание его состояло в том, что, низвергнутый в Тартар (ад), он вечно испытывает нестерпимые муки жажды и голода; он стоит по горло в воде, но вода отступает от него, как только он наклонит голову, чтобы напиться; над ним нависли ветви с роскошными плодами, но, как только он протягивает к ним руки, ветви отклоняются. Отсюда и возникло выражение «муки Тантала», имеющее значение: нестерпимые муки вследствие невозможности достигнуть желанной цели, несмотря на ее близость [URL : https://citaty.su/category/grecheskie-mify (дата обращения: 13.12.2020)].

${ }^{4}$ Крылатое выражение из сатиры древнегреческого писателя Лукиана (II в.), в которой разгневанный Юпитер, не находит более убедительного «аргумента» для своего оппонента Прометея, чем громовая стрела. В ответ на это Прометей говорит: «Ты берешься за молнию вместо ответа, — значит, ты не прав». Выражение адресуется человеку, который излишне горячится в споре, демонстрируя тем самым, что у него нет доказательств своей правоты, кроме собственных эмоций [URL : https:/www.litres.ru/natalya-viktorovna-b/hudozhestvennayaliteratura-i-mnogoe-drugoe-dlya-lubo/ (дата обращения: 13.12.2020)]. 


\section{Подстрочник:}

«Моя царица, если ты, подобно Юпитеру, злишься, значит, ты не права».

В пьесе «Иванов» персонаж Шабельский негативно характеризует всех врачей, называя их шарлатанами, преследующими материальную выгоду, и использует следующую аллюзию к греческой мифологии:

«Может быть, в какой-нибудь Аркадии ${ }^{5}$ попадаются исключения из общего правила, но... я в свою жизнь пролечил тысяч двадцать и не встретил ни одного доктора, который не казался бы мне патентованным мошенником».

В китайском издании 2014 года предлагается следующий перевод рассматриваемой реплики:

《也许，在阿尔卡吉亚，常列里边或许有几个例外，可是啊...我这一辈子里头，在医 生身上花去的就有两万左右, 可是我从来没有遇见过一个医生, 叫我觉着他不是一个领了 执照的骗子的。”

Переводчик не предлагает никаких пояснений относительно того, что такое Аркадия, и, как следствие, аналогия утеряна. В издании 1955 года предлагается более удачный вариант:

《除非在阿爾卡狄亞那種君子國，通則之中也許有個别的例外，可是......我這一辈子在 醫生身花過不下兩萬盧布, 可是, 據我看, 不是公然掛牌來騙人的醫生, 還一個也没有。》

\section{Подстрочник:}

«Если только в стране джентльменов ${ }^{6}$, вроде Аркадии...»

В этом варианте переводчик предлагает удачный симбиоз аллитерации и компенсации в виде отсылки к другому источнику — китайской мифологии, а именно к «Книге гор и морей» ${ }^{7}$.

Мы считаем также возможной замену аллюзии на 《世外桃源》 из поэмы «Персиковый источник» Тао Юаньмина ${ }^{8}$, которое не только представляет собой прецедентный феномен в принимающей культуре со значением страны блаженства, земного рая, но и образует отдельный интертекст в китайской литературе, так как на него ссылались многие поэты, в том числе Ли Бай ${ }^{9}$.

В ранних произведениях А. П. Чехова встречаются также многочисленные библейские аллюзии, которые, подобно мифологическим отсылкам, создают комичность ситуации и придают высказыванию ироничный тон. В рассказе «Тряпка»:

«Порисовавшись и поломавшись вдоволь, он уже взял секретаря под руку, и уже секретарь был у входа в Эдем, как послышался крик...» ${ }^{10}$.

В издании《契诃夫小说全集》(《Полное собрание коротких рассказов А. П. Чехова») вновь предлагается пояснение в виде сноски:

${ }^{5}$ Аркадия - центральная гористая часть Пелопоннеса, население которой в древности занималось скотоводством и земледелием, в классической литературе XVII-XVIII вв. изображалась как страна, где протекает счастливая, идиллическая жизнь земледельцев и пастухов. Отсюда в образной речи название этой страны и выражение «аркадская идиллия» употребляются (часто иронически) как синонимы счастливой страны и счастливой, беззаботной жизни [URL: https://citaty.su/category/grecheskie-mify (дата обращения: 13.12.2020)].

6 君子国 (миф.) - страна джентльменов, страна совершенных людей, с идеальными обычаями и нравами.

7 山海经 «Книга гор и морей» - древнекитайский трактат, описывающий реальную и мифическую географию Китая и соседних земель и обитающих там созданий.

8 晋·陶渊明. 《桃花源记》: 「这花园依山傍水, 四面苍松翠柏, 绿树成荫, 仿佛是世外桃源。」

9 唐. 李白. 古风诗五十九首之三十一：「一往桃花源, 千春隔流水。」

10 Эде́ - райский сад в Библии (Быт. 2:8), место первоначального обитания людей. 
《他不停的指手画脚, 装腔作势, 然后正要换住秘书的胳膊, 而且秘书也已经走到伊 甸园(10)门口，不料远处传来一声喊叫......

(10) 基督教传说中的天堂。»

Можно заметить, что переводчик предпочитает пользоваться комментариями в примечании, нам же представляется возможной образная замена на более близкие китайскому читателю религиозные понятия:

Наш перевод:

《秘书差点儿就迈过天堂门槛儿.......

Подстрочник:

«Секретарь чуть было не переступил порог рая...»

Есть среди интертекстуальных включений данного рассказа и источники литературного происхождения. Например, главный герой цитирует строки из известного монолога Татьяны Лариной из «Евгения Онегина» ${ }^{11}$ :

«А ведь сиастье было так близко, так возможно! - подумал секретарь, заглянув в открывшуюся дверь».

Наи перевод:

《“而那时幸福似乎已在望, 它就在眼前！ ${ }^{12}$ ”秘书看一眼敞打开的门里边, 暗暗想道。》

В данном случае нам представляется достаточным использование подстрочной ссылки, поясняющей источник цитаты, которую, впрочем, можно опустить, так как в данном примере в фокусе внимания оказывается не собственно источник цитаты, а комический эффект, и достаточно передать ироничный смысл высказывания.

Отсылки к литературным персонажам используются в основном именно в общепринятом понимании - для сокращения поясняющих характеристик и комментариев. В этом отношении излюбленным автором А. П. Чехова является В. Шекспир.

В рассказе «Ниночка» для описания склонности главной героини к неоправданной бурной ревности А. П. Чехов использует метафору «Отелло в юбке» (《穿裙子的奥赛罗»), а в «Истории неизвестного человека» в значении «ревновать» встречается выражение «разыгрывать Отелло» (《扮演奥赛罗»). В пьесе «Иванов» главный герой называет позором сравнение с «лишними людьми» («多余人») или «гамлетами» («哈姆雷特》). Знаковые фигуры и классические произведения мировой литературы хорошо знакомы китайскому читателю, поэтому не вызывают трудностей в процессе перевода и с большой степенью вероятности будут опознаны и декодированы в тексте перевода.

Особый интерес представляют случаи интертекстуальности, отсылающие читателя к невербальным источникам, а именно к живописи и историческим событиям, как, например, в рассказе «Тряпка».

«Там кипела жизнь! А бедный секретарь стоял перед дверью в позе кающегося грешника, à la Генрих в Каноссе, и глядел на дверь» ${ }^{13}$.

11 «А счастье было так возможно,

Так близко!.. Но судьба моя

Уж решена» [Пушкин, 1978, с. 139].

(Ответ Татьяны на письмо Евгения Онегина, в котором она признается ему в любви, но говорит о том, что она вышла замуж и, как верная жена, останется верна своему мужу.)

12 《叶甫盖尼・奥涅金》作者: [俄] 普希金

13 Эдуард Швойзер «Генрих в Каноссе» - сюжет картины посвящен эпизоду из истории средневековой Европы, известному также как Хождение в Каноссу или как Каносское унижение. Генрих IV, монарх Священной Римской империи, будучи недоволен тем, что папа римский Григорий VII на высокие посты назначает только своих людей, попытался отлучить его от церкви. Однако победу в конфликте одержал Папа. Генрих, чтобы принести покаяние Папе, отправился босой, в покаянной власянице к неприступной крепости Каносса, 
Haа перевод:

《在他们那儿生活正沸腾呢！而可怜的秘书却在门口站着, 现出忓悔的罪人的姿态, 好比画上的卡诺莎的享利。》

Подстрочник:

«У них там жизнь кипела! А бедный секретарь стоял у двери в позе кающегося грешника, совсем как на картине "Генрих Каносский”"».

Или в другом отрывке:

«Но, описывая живую картину “Юдифь и Олоферн”, в которой участвовала моя дочь, он... Бог знает что! Меч, говорит, который держала в руках Юдифь, так, говорит, длинен, что им можно зарезать только издали или же взлезши на крышу...» ${ }^{14}$.

Hаш перевод:

《那篇文章写到有我女儿参加的戏剧性场面“优尤季芙与奥罗费尔恩”...... 天知道是怎 么回事! 那篇文章说, 尤季芙手里拿的剑太长, 原来用于把巴比论统帅杀死了, 拯救了被困 难的犹太人，那篇文章说，要用那把剑砍人，只能站得很远，或者干脆爬到房顶上去。》

Подстрочник:

«В той статье писали о драматической сцене “Юдифь и Олоферн” с моей дочерью... Бог знает, что такое! В статье говорилось, что меч в руке Юдифь был слишком длинным. Меч, который использовался для того, чтобы убить вавилонского полководца и спасти бедных евреев! Так вот, в статье говорилось, что тот меч можно использовать, только если встать подальше или залезть на крышу».

Такие случаи, несомненно, нуждаются в пояснениях и комментариях, которыми мы сопровождаем текст перевода, а при возможности и в иллюстрациях, которые могли бы усилить комический эффект подобных сопоставлений.

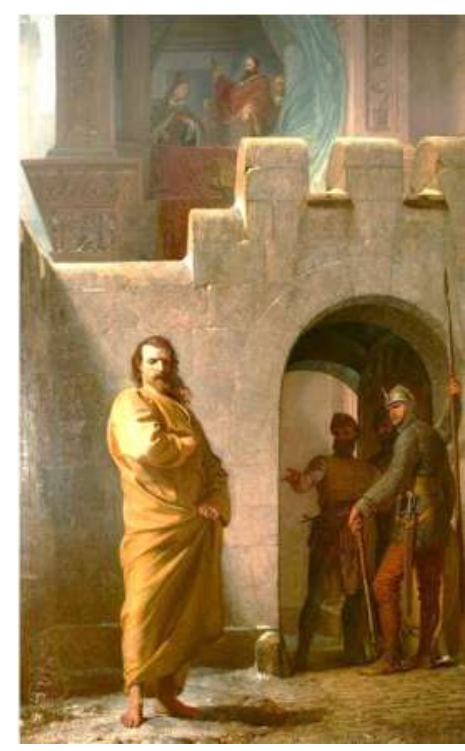

Эдуард Швойзер.

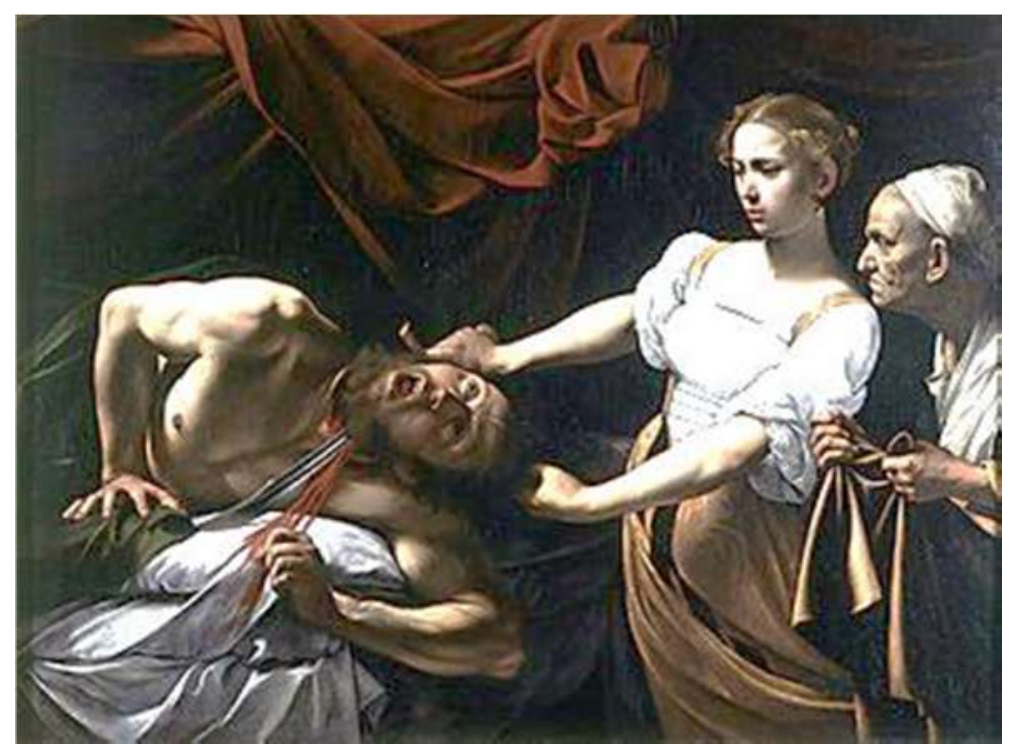

Микеланджело да Караваджо.

где находился понтифик. Лишь после трех дней стояния у закрытых ворот Генриха впустили и позволили в слезах вымолить прощение у Папы. Выражение «идти в Каноссу» используется в значении «соглашаться на унизительную капитуляцию» [URL: https:/w.histrf.ru/articles/article/show/gienrikh_iv_11_11_1050_goslar_07_ 08 1106 liezh (дата обращения: 13.12.2020)].

${ }^{\mathrm{T} 4}$ Микеланджело да Караваджо «Юдифь и Олоферн» (итал. Giuditta e Oloferne) — картина по мотивам ветхозаветной книги Иудифи. Олоферн был полководцем, вторгшимся в Иудею, где жила целомудренная молодая вдова Юдифь. Надежды не было никакой. Тогда надев красивые одежды, она со служанкой отправилась в стан врага и вошла в доверие Олоферна. Когда в один из вечеров он заснул, она отрезала ему голову и вернулась в родной город. Вражеская армия, оказавшись без военачальника, в панике разбежалась [URL : https://amp.ru.autograndad.com/1659830/1/yudif-i-olofern-kartina-karavadzho.html (дата обращения: 13.12.2020)]. 
Генрих в Каноссе. 1077 г.

Юдифь и Олоферн. 1599 г.

Проведенное исследование показывает, что интертекстуальность является важной категориальной характеристикой текста, назначение которой - обогатить текст новыми смыслами за счет диалогических отношений с предшествующими вербальными и невербальными источниками. Анализ механизмов интертекстуальности помогает не только лучше понять смысл произведения, но и осуществить более качественный перевод его на другой язык. При разности культур и экстралингвистического опыта различных языковых сообществ встает вопрос о возможности и необходимости сохранения интертекстуальных отсылок на языке перевода. Мы пришли к следующему выводу: имеет место зависимость перевода от степени прозрачности аллюзий, от локальности/всеобщности опыта и от близости/ отдаленности прецедентного текста во времени. При невозможности сохранить источник интертекста необходимо вскрыть механизм основополагающей ассоциации, чтобы затем с его помощью косвенным образом компенсировать в тексте перевода требуемый смысл. В то же время, если анализ оригинала показывает, что аллюзивная отсылка находится в периферии, а не в фокусе внимания адресата, возможно ее опущение в тексте перевода.

\section{Список источников}

1. Баженова Е. А. Интертекстуальность // Стилистический энциклопедический словарь русского языка / под ред. М. Н. Кожиной. - М. : Флинта : Наука, 2003. - С. 104-108.

2. Бахтин М. М. Эстетика словесного творчества / сост. С. Г. Бочаров, примеч. С. С. Аверинцева и С. Г. Бочарова. - М. : Искусство, 1979. - 423 с. — URL : http://teatr-lib.ru/Library/ Bahtin/esthetic/ (дата обращения: 13.12.2020).

3. Дейк Т. А. ван. Вопросы прагматики текста // Новое в зарубежной лингвистике. - Вып. 8 : Лингвистика текста. - М., 1978. - С. 259-336.

4. Запруднова А. А. Теория концептуальной интеграции как метод оценки адекватности перевода (на примере анализа перевода отрывков пьесы А. П. Чехова «Иванов») // Иностранные языки в высшей школе. - 2017. - № 2 (41). - С. 7-18.

5. Красных В. В. От концепта к тексту и обратно. К вопросу о психолингвистике текста // Вестник Московского университета. - Сер. 9 : Филология. - 1998. - № 1. - С. 53-70.

6. Кристева Ю. Бахтин, слово, диалог и роман // Французская семиотика: от структурализма к постструктурализму / пер. с фр., сост., вступ. ст. Г. К. Косикова. - М. : Прогресс, 2000. - C. 427-457.

7. Кубрякова Е. С. Язык и знание: На пути получения знаний о языке : части речи с когнитивной точки зрения. Роль языка в познании мира. - М. : Языки славянской культуры, 2004. - 560 с.

8. Кузьмина Н. А. Интертекст и его роль в процессах эволюции поэтического языка. - 3-е изд., испр. и доп. - М. : КомКнига, 2006. - 272 с.

9. Пушкин А. С. Евгений Онегин. Драматические произведения // Полн. собр. соч. : в 10 т. Л.: Наука, 1978. - С. 121-141.

10. Пьеге-Гро Н. Введение в теорию интертекстуальности : пер. с фр. / общ. ред. и вступ. ст. Г. К. Косикова. - М. : ЛКИ, 2008. - 240 с.

11. Смирнов И. П. Порождение интертекста (элементы интертекстуального анализа с примерами из творчества Б. Пастернака). - 2-е изд., испр. и доп. - СПб. : С-Петербург. ун-т, 1985. - $193 \mathrm{c}$.

12. Фатеева Н. А. Контрапункт интертекстуальности, или интертекст в мире текстов. - М. : Агар, 2000. - $280 \mathrm{c}$.

13. Филлмор Ч. Дело о падеже открывается вновь // Новое в зарубежной лингвистике. Вып. 10 : Лингвистическая семантика. - М. : Прогресс, 1981. - С. 496-531.

14. Чернявская В. Е. Интерпретация научного текста: стиль, текст, дискурс : учеб. пособие. 4-е изд. - М. : ЛКИ, 2007. - 127 с.

15. Чехов А. П. Собр. соч. : в 18 т. - Т. 12 : Пьесы. 1889-1891. — М. : Наука, 1978. — 926 с. 
16. Чумак-Жунь И. И. Художественный текст как феномен культуры: интертекстуальность и поэзия. - М. : Директ-Медиа, 2014. - 228 c. — URL : https://biblioclub.ru/index.php?page=book\&id= 235178 (дата обращения: 13.12.2020).

17. Ямпольский М. Б. Память Тиресия. Интертекстуальность и кинематограф. - М. : Культура, 1993. - $464 \mathrm{c}$.

18. Barthes R. Theory of the Text // Image Music Text / trans. Stephen Heath. - London : Fontana, 1977. - $220 \mathrm{p}$.

19. Fontanier P. Les Figures du discours. - Paris : Flammarion : Champs Classiques, 1977. — 125 p.

20. Grivel Ch. Tesis preparatorias sobre los intertextos // Intertextualité: Francia en el origen de un término y el desarrollo de un concepto. - La Habana : Casa de las Américas, 1997. — 215 p.

21. Lakoff G., Johnson M. Metaphors we live by. - Chicago : University of Chicago Press, 1980. $-354 \mathrm{p}$.

22. Langacker R. Concept, image, and symbol : the cognitive basis of grammar. - Berlin ; New York : Mouton de Gruyter, 1991. — 395 p.

23. Rubin, E. Figure and ground // Readings in perception / (Eds.) D. C. Beardslee, M. Wertheimer. Princeton, NJ : D. Van Nostrand, 1958. - Pp. 194-203.

24. Talmy L. Toward a Cognitive Semantics. - Vol. 1. - Cambridge : MIT Press, 2000 - URL : https://wings.buffalo.edu/linguistics//people/faculty/talmy/talmyweb/TCS.html (дата обращения: 13.12.2020).

25. Talmy L. Attention Phenomena // The Oxford handbook of cognitive linguistics / ed. by Dirk Geeraerts and Hubert Cuyckens. - NJ : Oxford University Press, 2007. - Pp. 264-293.

26. Taylor J. R Linguistic Categorization : Prototypes in Linguistic Theory. — Oxford : Clarendon Press, 1995. - $312 \mathrm{p}$.

27. 《伊凡诺夫·海鸥》[俄] 契诃夫 上海译文出版社 / 2014年11月. (Чехов А. П. Иванов. Чайка. Шанхай : Изд-во переводов, 2014.)

28. 伊凡諾夫 契訶夫著 人民文學出版社出版/ 一九五五年诃北京. (Чехов А. П. Иванов. Пекин : Жэньминьвэньсюэ, 1955.)

29. 《叶甫盖尼·奥涅金》作者: [俄] 普希金 (Пушкин А. С. Евгений Онегин. 一 URL : https:// www.gezhongshu.com/forum.php?mod=viewthread\&tid=11293 (дата обращения: 13.12.2020).

30. 《契诃夫小说全集》(Полное собрание рассказов А. П. Чехова. - URL : https:// www.doc88.com/p-31778741272.html (дата обращения: 13.12.2020)).

\section{References}

1. Bazhenova E. A. Intertextuality. Stilisticheskij enciklopedicheskij slovar' russkogo yazyka [Stylistic Encyclopedic Dictionary of the Russian Language]. Moscow, Flinta, Science Publ., 2003, pp. 104-108.

2. Bakhtin M. M. Estetika slovesnogo tvorchestva [Aesthetics of verbal creativity]. Moscow, Art Publ., 1979, 423 p. Awailable at: https://teatr-lib.ru/Library/Bahtin/esthetic/ (accessed 13.12.2020)

3. Dijk T. A. van. Questions of the pragmatics of the text. Novoye $v$ zarubezhnoy lingvistike Vip. 8. Lingvistika teksta [New Trends in Foreign Linguistics. Iss. 8. Linguistics of the text]. Moscow, 1978, pp. 259-336.

4. Zaprudnova A. A. Conceptual Integration Theory as a Basis for Assessing the Adequacy of Translation (illustrated by excerpts from A. Chekhov's "Ivanov" translated into Chinese). Inostrannye yazyki v vysshei shkole [Foreign Languages in Tertiary Education]. 2017, no. 2 (41), pp. 7-18.

5. Krasnykh V. V. From concept to text and back. On the question of the psycholinguistics of the text. Vestnik moskovskogo universiteta [Moscow University Bulletin]. Ser. 9. Philology. 1998, no. 1 , pp. 53-70.

6. Kristeva J. Bakhtin, word, dialogue and novel. Frantsuzskaya semiotika: ot strukturalizma $k$ poststrukturalizmu [French semiotics: From structuralism to poststructuralism]. Tr. from French. Moscow, Progress Publ., 2000. pp. 427-457. 
7. Kubryakova E. Yazayk i znaniye: na puti polucheniya znaniy o yazyke: chasti rechi s kognitivnoy tochki zreniya. Rol' yazyka v poznanii mira [Language and knowledge: On the way to gaining knowledge about language: Parts of speech from a cognitive point of view. The role of language in the knowledge of the world]. Moscow, Languages of Slavic culture Publ., 2004, 560 p.

8. Kuzmina N. A. Intertekst I yego rol'v protsessakh evolyutsii poeticheskogo yazyka [Intertext and its role in the evolution of poetic language]. 3rd ed., rev. and compl. Moscow, KomKniga Publ., 2006, 272 p.

9. Pushkin A. S. Eugene Onegin. Dramatic works. Polnoye sobraniye sochineniy v 10 tomakh [Collected works]. In 10 vols. Leningrad, Science Publ., 1978, pp. 121-141.

10. Piegay-Gros N. Vvedeniye v teoriyu intertekstual'nosti [Introduction to the theory of intertextuality]. Tr. from French. Introduction by G. K. Kosikov. Moscow, LKI Publ., 2008, 240 p.

11. Smirnov I. P. Porozhdeniye interteksta (elementy intertekstual'nogo analiza s primerami iz tvorchestva B. Pasternaka) [Generation of intertext (elements of intertextual analysis with examples from the work of B. Pasternak)]. 2nd ed., corrected and supplemented by the author. Sankt-Peterburg, Peterburgskii gos. un-t Publ., 1995, 193 p.

12. Fateeva N. A. Kontrapunkt itertekstual'nosti, ili intertekst $v$ mire tekstov [The counterpoint of intertextuality, or intertext in the world of texts]. Moscow, Agar Publ., 2000, 280 p.

13. Fillmore Ch. The case of the case reopens. Vip. 10. lingvisticheskaya semantika Novoye $v$ zarubezhnoy linvistike [New trends in foreign linguistics. Iss. 10. Linguistic semantics]. Moscow, Progress Publ., 1981, pp. 496-531.

14. Chernyavskaya V. E. Interpretatsiya nauchnogo teksta: stil', tekst, diskurs: ucheb. posobiye [Interpretation of scientific text: Style, text, discourse: tutorial]. 4th. ed. Moscow, LKI Publ., 2007, 127 p.

15. Chekhov A. P. Sobraniye sochineniy v 18 tomakh. Tom 12. P'yesy 1889-1891 [Collected works in 18 vols. Vol. 12. Plays 1889-1891]. Moscow, Science Publ., 1978, 926 p.

16. Chumak-Zhun I. I. Khudozhestvenniy tekst kak phenomen kul'tury: intertekstual 'nost' $i$ poeziya [Artistic text as a cultural phenomenon: intertextuality and poetry]. Moscow, Direct-Media Publ., 2014, 228 p. Awailable at: https://www.biblioclub.ru/index.php?page=book\&id=235178 (accessed 13.12.2020).

17. Yampolsky M. B. Pamyat' Tiresiya. intertekstual'nost' $i$ kinematograf [Memory of Tiresias. Intertextuality and cinematography]. Moscow, Culture Publ., 1993, 464 p.

18. Barthes R. Theory of the Text. Image Music Text. Trans. Stephen Heath. London, Fontana, $1977,220 \mathrm{p}$.

19. Fontanier P. Les Figures du discours. Paris, Flammarion "Champs", 1977, 125 p.

20. Grivel Ch. Tesis preparatorias sobre los intertextos. Intertextualité: Francia en el origen de un término y el desarrollo de un concepto. La Habana, Casa de las Américas, 1997, 215 p.

21. Lakoff G., Johnson M. Metaphors we live by. Chicago, University of Chicago Press, 1980, 354 p.

22. Langacker R. Concept, image, and symbol: the cognitive basis of grammar. Berlin, New York, Mouton de Gruyter, 1991, 395 p.

23. Rubin E. Figure and ground. D. C. Beardslee, M. Wertheimer (Eds.) Readings in perception. Princeton, NJ, D. Van Nostrand, 1958, pp. 194-203.

24. Talmy L. Toward a Cognitive Semantics. Vol. 1. Cambridge, MIT Press, 2000. Awailable at: https://wings.buffalo.edu/linguistics//people/faculty/talmy/talmyweb/TCS.html (accessed 13.12.2020)

25. Talmy L. Attention Phenomena. Ed. by Dirk Geeraerts, Hubert Cuyckens. The Oxford handbook of cognitive linguistics. NJ, Oxford University Press, 2007, pp. 264-293.

26. Taylor J. R Linguistic Categorization: Prototypes in Linguistic Theory. Oxford, Clarendon Press, 1995, $312 \mathrm{p}$.

27. 伊凡诺夫·海鸥 [俄] 契诃夫 上海译文出版社 / 2014年11月. (Chekhov A. P. (Rus.). Ivanov. Seagull. Shanghai Translation Publishing House, 2014) (In Chinese).

28. 伊凡諾夫 契訶夫著 人民文學出版社出版/ 一九五五年诃北京. (Chekhov A. P. Ivanov. Beijing, Renmin Wenxue Chubanshe, 1955) (In Chinese).

29. 《叶甫盖尼·奥涅金》作者：[俄] 普希金 (Pushkin A. S. Eugene Onegin) (In Chinese). Awailable at: https:// www.gezhongshu.com/forum.php?mod=viewthread\&tid=11293 (accessed 13.12.2020).

30. 《契诃夫小说全集》(Complete Collection of Short Stories by A. P. Chekhov) (In Chinese). Awailable at: https://www.doc88.com/p-31778741272.html (accessed 13.12.2020). 


\section{Информация об авторе}

Запруднова Анастасия Алексеевна - ведущий специалист по учебно-методической работе научно-образовательного подразделения «Институт Конфуция» Рязанского государственного университета имени С. А. Есенина, старший преподаватель кафедры восточных языков и методики их преподавания института иностранных языков РГУ имени С. А. Есенина. Почтовый адрес: 390000, г. Рязань, ул. Свободы, д. 46. Тел. (раб.): (4912) 97-15-15 (доб. 2047).

\section{Information about the author}

Zaprudnova, Anastasia - Senior Education Management Officer of Confucius Institute, Ryazan State University named for S. A. Esenin, Senior Lecturer, Dpt. of. Oriental Languages and Language Teaching Methodology, Foreign Languages Institute, Ryazan State University named for S. A. Esenin, Postal address: 46 Svobody St., Ryazan, 390000, Russia. Tel.: (4912) 97-15-15 (ext. 2047).

Статья поступила в редакциию: 03.04.2021;

одобрена после рецензирования: 23.04.2021;

принята к публикации: 23.04.2021.

Submitted: 03.04.2021;

approved after reviewing: 23.04.2021;

accepted for publication: 23.04 .2021 . 
Иностранные языки в высшей школе. 2021. № 2 (57). С. 99-107.

Foreign Languages in Tertiary Education. 2021;2(57):99-107.

Научная статья

УДК $821.161 .1+81$ '255

DOI: $10.37724 /$ RSU.2021.57.2.009

\section{Перевод и изучение творчества И. А. Крылова в Китае}

\section{Ли Чуньюй}

Институт иностранных языков Сямэньского университета, Сямэнь, Китай

wjlichunyu@163.com

Аннотация. В статье прослеживается история перевода и распространения в Китае басен И. А. Крылова - первого русского писателя, чьи произведения были переведены на китайский язык, широко известны и распространены в Китае. Сравниваются прозаические и стихотворные переводы басен И. А. Крылова в разные периоды, анализируются также состояние и перспективы крылововедения в Китае. вод, Китай.

Ключевые слова: басня, драматургия, И. А. Крылов, поэтический перевод, прозаический пере-

Для цитирования: Ли Чуньюй. Перевод и изучение творчества И. А. Крылова в Китае // Иностранные языки в высшей школе. 2021. № 2(57). С. 99-107. DOI: 10.37724/RSU.2021.57.2.009.

Original article

\section{Translation and Study of I. A. Krylov's Works in China}

\section{Li Chunyu}

Xiamen University, Xiamen, China

wjlichunyu@163.com

Abstract. Krylov is the first Russian writer whose work was translated into Chinese. Krylov's fables are widely known and spread in China. This article traces the history of translation and publication of Krylov's fables in China, compares prosaic and poetic translations in different periods. The status and prospects of the study of Krylov in China are also analyzed.

Keywords: fable, drama, I. A. Krylov, poetic translation, prose translation, China.

For citation: Li Chunyu. Translation and Study of I. A. Krylov's Works in China. Foreign Languages in Tertiary Education. 2021;2(57):99-107. (In Russ.). DOI: 10.37724/RSU.2021.57.2.009.

\section{Введение}

И. А. Крылов - один из трех известнейших баснописцев мира, наряду с Эзопом (620-564 до н. э.) и Жаном Де Лафонтеном (1621-1695). При этом китайские ученые сходятся во мнении, что «по обаянию и художественной ценности произведений Крылов превзошёл его предшественников» [Хэ Маочжэн, 2000, с. 51]. Об этом свидетельствует широкое распространение басен Крылова по всему Китаю в самых разных изданиях. На официальном сайте Китайской национальной библиотеки по ключевому слову “克雷洛夫寓言” («басни Крылова») найдутся 78 разных изданий (без учета многократных переизданий многих из них). Другим убедительным доказательством большой популярности басен Крылова в Китае служит и тот факт, что, помимо китайского языка, они переведены еще и на языки 
четырех национальных меньшинств Китая, что очень редко бывает в истории перевода иностранной литературы в Китае: на казахский (Урумчи : Синьцзянское нар. изд-во, 1981, 2010), корейский (Шэньянь : Шэньянское нар. изд-во, 1983), монгольский (Хух-Хото : Образовательное изд-во Внутренней Монголии, 2006) и уйгурский (Урумчи : Синьцзянское нар. изд-во, 2007). Кроме того, басни Крылова издавались «Китайским книжным издательством» (г. Пекин) также и на английском языке в переводе британца Бернарда Пэйрза в целях изучения английского языка: в 2004 году они были опубликованы с переводом на китайский язык, а в 2007 году - без перевода.

\section{История перевода басен И. А. Крылова в Китае}

И. А. Крылов - самый первый русский писатель, чьи произведения были переведены на китайский язык. Впервые китайские читатели познакомились с баснями Крылова более 120 лет тому назад. С декабря 1899 года по май 1900 года в 131-136 номерах одного из самых влиятельных китайскоязычных периодических изданий того времени - журнала “Review of the Times” («万国公报 Wànguó gōngbào»), созданного в 1868 году в Шанхае американским миссионером Янгом Дж. Алленом (1836-1907), печаталась частями книга «Политика и обычаи Российской империи» (《俄国政俗通考》), куда вошли три басни Крылова: «Дружба собак», «Щука» и «Лисица и сурок». Переводы басен с английского на вэньянь - традиционный книжный язык Китая, принадлежат перу самого создателя и главного редактора журнала Я. Дж. Аллена и его китайского помощника Жэнь Тинсюя. В качестве формы, следуя китайской традиции написания басен, они применяли прозу. Бичуя лицемерие, взяточничество и несправедливое правосудие, эти басни отражали состояние китайского общества того времени. Стоит особо отметить, что переводные тексты были дополнены лаконичными и меткими рассуждениями переводчиков, написанными в манере Крылова, и поэтому вполне могут рассматриваться как органическая составная часть произведений. Так, например, дополняет перевод басни «Щука» следующее рассуждение: «До чего хитра лиса! Уговорила тех, кто приговорил Щуку к смерти, отпустить убийи на волю! А обманутые даже нисколько не сомневаются в честности лисы. Разве судьи, злоупотребляющие своим служебным положением в интересах преступников, прочитав басню, не чувствуют свою вину?» [Чэнь Цзяньхуа, 1996, с. 98].

С начала XX века до 30-40-х годов на фоне антифеодальной и антиимпериалистической борьбы народа страны китайская интеллигенция в большом количестве переводила произведения русской и советской литературы, которые сравнивались основоположником современной китайской литературы Лу Синем с боеприпасами, доставляемыми контрабандой восставшим рабам. В этой связи наибольшей популярностью пользовались посвященные Гражданской и Великой Отечественной войне повествовательные прозаические произведения советских писателей, такие, как «Разгром» и «Молодая гвардия» А. Фадеева, «Железный поток» А. Серафимовича, «Как закалялась сталь» Н. Островского и т. д. На этом фоне басни Крылова отошли на второй план.

После образования Китайской Народной Республики басни Крылова снова привлекли к себе внимание. В 50-х годах XX века появилось несколько изданий переводов его басен. Так, в 1951 году в Шанхае в издательстве «Эпоха» вышел первый в Китае сборник басен Крылова в переводе Мэнхая (настоящее имя - Чэнь Цзюньши), куда вошли 20 басен, а в новом издании 1955 года, опубликованном в Пекине в издательстве «Китайская молодежь», число включенных произведений увеличилось до 84. В 1954 году известный переводчик английской литературы У Янь предложил к изданию перевод сборника с 201 басней (Шанхай : Новая литература и искусство). В отличие от Мэнхая, переводившего непосредственно с русского, У Янь переводил с английской версии, выполненной британцем Бернардом Пэйрзом, которая по праву считается самой удачной среди всех англоязычных вер- 
сий. Оба перевода осуществлялись в прозе, как и Янгом Дж. Алленом, только на повседневном разговорном языке - байхуа. Перевод У Яня, благодаря высокому уровню мастерства, получил широкое признание и рекомендовался ЦК комсомола и Министерством образования Китая молодым читателям, многократно переиздавался и до сих пор считается одним из лучших. Помимо вышеупомянутых изданий, в 1955 году басни Крылова вышли в свет в иллюстрированном виде в переводе Чэнь Цифэна (Пекин : Народное художественное изд-во), а в 1960 году издан небольшой сборник басен Крылова на китайском и русском языках, ориентированный на изучающих русский язык.

С середины 1960-х до середины 1970-х годов в связи с проходившей в Китае культурной революцией (1966-1976), стали практически невозможными перевод и издание русской и советской литературы в целом и басен Крылова в частности как сатирических произведений. С конца 1970-х годов переиздания Крылова возобновились, в первую очередь в переводах Мэн Хая и У Яня в прозе, позже появились новые переводы в стихах. С вступлением в новый век по всему Китаю басни Крылова выходят большими тиражами в самых разных изданиях. Из существующих 78 изданий около 60 вышли в свет в течение 2000-2019 годов, то есть по три издания ежегодно. Число произведений, включенных в эти издания, колеблется от десятков басен до двухсот и более. Помимо изданий в адаптированном или сокращенном виде, предназначенных главным образом для детей, существуют как минимум 27 полноценных и независимых переводов на китайский язык, выполненных 33 переводчиками.

В трудностях перевода басен Крылова признается практически каждый китайский переводчик. У Янь в послесловии к новому изданию 1979 года, ссылаясь на В. Г. Белинского, отметил: «Строго говоря, басни Крылова непереводимы» [У Янь, 1979, с. 329]. Несмотря на многократное переиздание и широкое признание, У Янь самокритично относится к своему прозаическому переводу, который, по его словам, «носит переходный характер и всего лишь временная замена до того, как появится изящный стихотворный перевод непосредственно с русского» [У Янь, 1979, с. 330]. В 1983 году в переводе Хэ Шиина наконец вышел в свет самый первый стихотворный перевод басен Крылова на китайский язык (Гуанчжоу : Хуачэн). Признавшись в «несовершенстве своего перевода», переводчик представил его с желанием «привлечь внимание к басням Крылова, все еще ожидающим достойного стихотворного перевода на китайский язык» [Хэ Шиин, 1983, с. 403]. В 1992 году известный переводчик Синь Вэйай предложил свой стихотворный перевод (Шанхай : Шанхайское изд-во переводной литературы), который вызвал оживленный спор. Исследователь Хань Гуйлян первым из китайских ученых провел тщательный анализ стихосложения, размера, рифмовки басен Крылова, на основе чего убедительно указал на существенные недостатки перевода Синь Вэйая, включая перемещение строк, рифмовку и т. д. В качестве примера можно привести перевод эпимифия басни «Госпожа и две служанки»:

$* * *$

Так выбраться желая из хлопот, Нередко человек имеет участь ту же:

Одни лишь только с рук сживет,

Глядишь — другие нажил хуже!

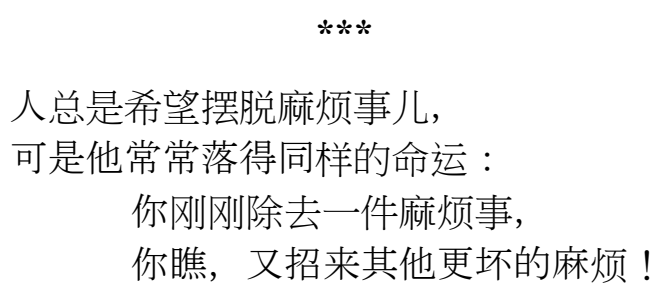

你瞧，又招来其他更坏的麻烦！

Как видно из приведенного примера, в оригинале применяется вольный ямб и перекрестная рифмовка, а переводной текст сочиняется вообще без рифмы. В то же время переводчик механически копирует особую стихотворную графику, подчеркивающую различную длину строк различным их отступом от левого края, что непривычно для китайского стихосложения на байхуа и вызывает недоумение у читателей. 
Недостатки стихотворных переводов басен Крылова на байхуа исследователь объясняет, «с одной стороны, непереводимостью басен Крылова, а с другой стороны, недостаточной развитостью современной китайской поэзии и отсутствием у нее общепринятого стандарта» [Хань Гуйлян, 1994, с. 67]. Исходя из таких же соображений, известный переводчик, поэт, каллиграф Чэнь Цыюань прибегал к классической поэзии, отличающейся от современной поэзии общепринятыми правилами стихосложения. В пятом номере журнала «Советская литература» за 1985 год были напечатаны переводы шести басен Крылова («Лещи», «Кукушка и орёл», «Вельможа» «Волк на псарне», «Пёстрые овцы», «Волк и пастухи») с традиционной длиной строки из пяти или семи иероглифов. Так, например, в конце басни «Волк на псарне» [Чэнь Цыюань, 1985, с. 67] соблюдены в переводном тексте каноны древних семисловных стихов:

\begin{tabular}{ll}
\multicolumn{1}{c}{$* * * *$} & \multicolumn{1}{c}{$* * *$} \\
Послушай-ка, сосед, - & 猎手插口把狼斥: \\
Тут ловчий перервал в ответ, - & “休得鼓舌如笙簧! \\
Ты сер, а я, приятель, сед, & 倘谓汝毛老成灰, \\
И волчью вашу я давно натуру знаю; & 而我己白发苍苍! \\
А потому обычай мой: & 狠性狡戏早看透, \\
С волками иначе не делать мировой, & 谈和无非屈膝降。 \\
Как снявши шкуру с них долой». & 与汝相交只一途, \\
И тут же выпустил на Волка гончих стаю. & 立将汝皮剥精光!” \\
& 言毕放出猎犬群, \\
& 直扑灰毛老恶狼。
\end{tabular}

Каждая строка состоит из семи иероглифов, и все четные строки заканчиваются одной и той же рифмой — “ang”: 簧(huang)-苍(cang)-降(xiang)-光(guang)-狼(lang). Данная попытка довольно интересна, хотя по сравнению со свободной стихотворной формой оригинала, имеющей фольклорные корни, перевод получился слишком строгим.

Начиная с середины 1990-х годов один за другим вышли новые стихотворные переводы басен И. А. Крылова, среди которых можно выделить переводы Хэ Маочжэна (Ханчжоу : Чжэцзянское изд-во литературы и искусства, 1997), Гу Юя (Пекин : Яньшань, 2004 ; Пекин : Народная литература, 2019) и Ши Госюна (Наньцзин : Илинь, 2017). Но тем не менее прозаический перевод У Яня по сравнению с этими стихотворными переводами нисколько не теряет своего значения благодаря простоте и образности языка, что особенно привлекает юных читателей.

\section{Изучение жизни и творчества И. А. Крылова в Китае}

Что касается изучения биографии И. А. Крылова, то оно началось только после образования Китайской Народной Республики. В 1950 году была опубликована в Шанхае издательством «Эпоха» в переводе Мэн Хая на китайский язык книга С. Н. Дурылина «И. А. Крылов. Краткий очерк жизни и творчества» (М. : Гослитиздат, 1944), а в 1983 году вышла в свет в Харбине в Хэйлунцзянском народном издательстве в переводе Хэ Маочжэна и Тянь Баоши книга Н. Л. Степанова «И. А. Крылов. Жизнь и творчество» (М. : Гослитиздат, 1949). Именно эти публикации положили начало китайскому крылововедению; на них часто ссылаются и по сей день. Первая научная статья о Крылове опубликована в 1957 году. Высоко оценив боевой характер и прогрессивность басен Крылова, обладающих «вечными нравственными и эстетическими ценностями» [Шэн Мэйди, 1957, с. 19], автор статьи в то же время отметил, что «из-за ограниченности своей эпохи в некоторых баснях отражаются противоречивые мысли. В баснях «Чиж и ёж» и «Василёк» отражается иллюзорная мечта 
о добром царе... и консервативное мировоззрение писателя» [Шэн Мэйди, 1957, с. 19]. Стоит отметить, что такое мнение, характерное для той эпохи, когда идейности в обществе отводилась ключевая роль, было довольно распространено среди китайских учёных вплоть до 80-х годов XX века. Так, учёные считали, что «Чиж и ёж» - это ода Александру I и что баснописец самокритично рассказывает о своем даре, сравнивая себя со скромным Чижом. На самом же деле, эта басня не столько скромная ода, сколько остроумный отказ от похвального хора, в ней нетрудно заметить ироническое отношение баснописца как к талантливым соловьям, под которыми понимаются прославлявшие императора поэты - Г. Р. Державин, Н. М. Карамзин и В. А. Жуковский, так и к самому императору, ставшему спасителем Европы исключительно за счет усилий и таланта «смоленского князя» М. И. Кутузова, которого Крылов неоднократно восхвалял в своих произведениях («Ворона и курица», «Волк на псарне», «Обоз»). Более того, ни для кого не секрет, что Александр I часто фигурирует в баснях Крылова в образе льва, демонстрируя свое лицемерие, жестокость и коварность («Пестрые овцы», «Рыбья пляска»).

Комментируя басни Крылова, китайские исследователи часто прибегают к сравнительному подходу. Кроме Эзопа и Жана де Лафонтена, с кем часто сравнивают Крылова русские исследователи, китайские учёные также сопоставляют его с отечественными писателями, например с Лю Цзунъюанем (773-819), известным поэтом и баснописцем династии Тан, внёсшим наиболее существенный вклад в развитие китайских басен. Путем сопоставления исследователи пришли к выводу, что, несмотря на разницу в форме (Крылов пишет в стихах, а Лю - в прозе) и стиле (у Крылова больше иронии, а у Лю - острой критики), творчество обоих баснописцев сближает общая идейная направленность, заключающаяся в разоблачении правящих классов и защите прав угнетенных [Хэ Цзинсян, Ян Ваньи, 2011, с. 43-46]. Чэнь Цыюань, анализируя стиль Крылова, сравнил его с известным поэтом династии Тан - Бо Цзюйи (772-846), который тоже стремился к тому, чтобы его стихотворения без труда понимали как маленькие дети, так и неграмотные старухи [Чэнь Цыюань, 1985, c. 126-130]. Другой исследователь Хуан Футун также сопоставил басни Крылова с известнейшим классическим романом Китая - «Сон в красном тереме» Цао Сюэциня (1715-1763). Несмотря на имеющиеся отличия, произведения обоих писателей обладают общим достоинством: «...если Крылов своим остроумным пером описывает мир персонифицированных животных, то Цао Сюэцинь поэтическим языком рассказывает о мире людей, деградирующих в животных. При этом оба писателя направляют свой удар феодальной аристократии и правящим классам своего времени. И оба во избежание цензуры прибегают к аллегорической форме» [Хуан Футун, 1979, с. 20].

В целом изучение творчества Крылова с позиций литературоведения и перевода значительно отстает от популярности его басен у китайских читателей. В национальной базе научных публикаций Китая (CNKI - China National Knowledge Infrastructure) по ключевым словам “克雷洛夫”, “克雷洛夫寓言” («Крылов», «Басни Крылова») найдутся всего около 70 статей и диссертаций, опубликованных в течение 70 лет после образования Китайской Народной Республики. На сегодняшний день нет ни одной монографии.

Однако отрадно отметить, что в последние годы наблюдается тенденция повышения научного интереса к басенному творчеству Крылова, чему начали посвящаться диссертации на соискание степени магистра филологических наук. Среди них особо выделяются следующие: аспирант Ляонинского университета Ван Лицзя рассматривала басни Крылова, посвященные Отечественной войне 1812 года [Ван Лицзя, 2013], аспирант Сямэньского университета Чжао Гуйи исследовала особенности эмоционально-оценочной лексики в баснях Крылова [Чжао Гуйи, 2014], аспирант Гуандунского университета иностранных языков и внешней торговли Шао Лили анализировала логоэпистему в баснях Крылова [Шао Лили, 2017], а аспиранты Сюй Шуаншуан из Шанхайского университета иностранных языков и Цяо Нинань из Сычуаньского университета иностранных языков изучали перевод басен 
Крылова на китайский язык с точки зрения теории адаптации [Сюй Шуаншуан, 2018] и в ракурсе теории текста [Цяо Нинань, 2019] соответственно. Различные научные подходы, применяемые при исследовании басен Крылова в вышеупомянутых диссертациях, дают основание говорить о грядущем расцвете изучения басен Крылова в Китае.

Одно из самых приоритетных, на наш взгляд, направлений в данной сфере - это конкретное влияние басен Крылова на творчество современных китайских баснописцев. Известный китайский специалист по басням Тань Сюйдун отметил, что «именно благодаря Крылову и Лафонтену, современные китайские баснописцы осознали возможность сочетания художественности басен с критической остротой и народностью» [Тань Сюйдун, 2012]. Однако нет научных исследований, доказывающих прямую творческую связь между Крыловым и современными китайскими баснописцами. А такая связь, без всякого сомнения, существует. В качестве примера можно привести сюжеты басен Фэн Сюэфэна (1903-1976), основоположника современной китайской басни, некоторые из которых явно заимствованы у Крылова. Например, в басне «Змея и заяц» Фэн Сюэфэна рассказывается о том, как змея, ставшая судьей, легализовала охоту на зайцев. Образ вороватого судьи часто встречается и в баснях Крылова в облике лисицы («Крестьянин и овца») и волка («Волки и овцы»). Убедительным примером является также басня «Колодец и река» Фэн Сюэфэна, по содержанию и морали - почти точная копия «Пруда и реки» Крылова. Колодец, как и пруд, символ самодовольных, топчущихся на месте, - противопоставляется реке - символу постоянно развивающихся, идущих в ногу со временем. В результате колодец и пруд обречены на гибель, а реку ждет полноценная жизнь и успех.

Кроме того, заслуживает углубленного изучения также и драматургия Крылова. Отсутствие перевода драматургии Крылова на протяжении долгих лет привело к тому, что в Китае мало кто знает о Крылове-драматурге. То же самое можно сказать и о сатирической прозе Крылова, опубликованной в журналах «Почта духов», «Зритель» и «Санкт-Петербургский Меркурий». Изучение драматургии, публицистики и прозы Крылова не только позволяет нам лучше освоить его литературное наследие, но и помогает осознать их глубину, понять суть и особенности его басен. В этом смысле значительным событием можно назвать издание в Китае сборника пьес Крылова в 2020 году, представленного Сычуаньским народным издательством в рамках серии переводов «Золотая Россия», куда вошли все 13 драматических произведений Крылова. В предисловии к сборнику переводчик высоко оценил художественную ценность пьес Крылова, доказав явное влияние его «Урока дочкам» на «Ревизора» Н. В. Гоголя [Ли Чуньюй, 2020, с. 20]. Недаром Ма Линь сравнивает Крылова-драматурга с «мостом, связывающим классицизм XVIII века с реализмом XIX века в истории русской драматургии» [Ма Линь, 2020, с. 93]. Со временем, по нашему убеждению, драматургия Крылова привлечет к себе все больше внимания со стороны китайских исследователей и читателей.

\section{Заключение}

Басни Крылова, «кристаллизация ума, опыта и силы» [Хуан Футун, 1979, с. 23], известны в Китае каждой семье и каждому дому. Начиная с 1899 года переводом басен Крылова на китайский язык занималось не одно поколение переводчиков. В течение более 80 лет существовали только прозаические переводы, сначала на вэньяне (Янг Джон Аллен и Жэнь Тинсюй), потом на байхуа (Мэн Хай, У Янь). После появления самого первого стихотворного перевода в 1983 году, Хэ Маочжэн, Гу Юй, Ши Госюн и многие другие выдающиеся переводчики стараются изо всех сил предложить достойный оригинала стихотворный перевод. И, судя по всему, эта работа будет продолжаться в течение долгого времени. По сравнению с широким распространением басен Крылова состояние крылововедения в Китае оставляет желать лучшего. Но положительная тенденция последних лет в целом и издание пьес Крылова в частности дают нам основание говорить о грядущем расцвете исследования наследия Крылова в Китае. 


\section{Список источников}

1. 陈次园.试译克雷洛夫寓言诗六首.《苏联文学》, 1985年第5期, 126-130页。Чэнь Цыюань. Перевод шести басен И. А. Крылова на китайский // Советская литература. - 1985. - № 5. C. $126-130$.

2. 陈建华.从《俄人寓言》到《克雷洛夫寓言》一一谈谈中国早期的俄国文学译介.《中国比 较文学》, 1996年第1期, 90-100页。 Чэнь Цзяньхуа. От «Басни русского народа»к «Басням Крылова» - о раннем этапе распространения русской литературы в Китае // Китайская сравнительная литература. - 1996. - № 1. - С. 90-100.

3. 杜雷林著, 梦海译. 《克雷洛夫评传》.上海 : 时代出版社, 1950年, 95页。Дурылин C. Н. И. А. Крылов. Краткий очерк жизни и творчества / пер. Мэн Хая. — Шанхай : Эпоха, 1950. — 95 с.

4. 韩桂良.克雷洛夫寓言是诗一一读辛译《克雷洛夫寓言集》的几点感想.《外国语》1994年 第1期, 第65-70页。 Хань Гуйлян. Басня Крылова - это стихотворение : рецензия к «Сборнику басен Крылова» в переводе Синь Вэйая // Иностранные языки. - 1994. — № 1. - С. 65-70.

5. 何静翔, 杨万毅. 柳宗元与克雷洛夫寓言作品比较研究的意义综述. 《昌吉学院学报》, 2011年第1期, 43-46页。 Хэ Цзинсян, Ян Ваньи. Значение сопоставления басен Лю Цзунъюаня и И. А. Крылова // Вестник Чанцзийского института. — 2011. — № 1. - С. 43-46.

6. 何茂正. 我译克雷洛夫寓言全集. 《俄罗斯文艺》, 2000年第1期, 51-56页。Хэ Маочжэн. Как я переводил сборник басен Крылова // Русская литература и искусство. - 2000. - № 1. C. $51-56$.

7. 何世英. 译后记. 《克雷洛夫寓言诗集》, 广州 : 花城出版社, 1983年, 403页。Хэ Шиин. Послесловие к переводу // Сборник басен Крылова. - Гуанчжоу : Хуачэн, 1983. - 403 с.

8. 黄弗同. 满纸荒唐言, 一把辛酸泪——读克雷洛夫寓言散记.《外国文学研究》, 1979年第2 期, 20-23页。 Хуан Футун. Сопоставление басен Крылова со «Сном в красном тереме» Сао Сюэциня // Исследование по иностранной литературе. - 1979. - № 2. - С. 20-23.

9. 李春雨. 克雷洛夫的戏剧创作 (译序). 《法国侯爵一一克雷洛夫剧作集》, 成都：四川 人民出版社，2020年，572页。Ли Чуньюй. Драматургическое творчество Крылова (Предисловие) // Крылов И. А. Сборник пьес Крылова. - Чэнду : Сычуаньское нар. изд-во, 2020. - 572 с.

10. 马琳. 克雷洛夫戏剧创作的喜剧性. 《戏剧文学》, 2020年第8期, 93-103页。 Ма Линь. Комедийность драматургического творчества Крылова // Драматургия. - 2020. - № 8. C. 93-103.

11. 谯妮楠. 克雷洛夫寓言汉译的语篇翻译研究. 硕士研究生学位论文, 四川外国语大学, 2019。 Цяо Нинань. Исследование перевода басен И. А. Крылова на китайский язык в ракурсе теории текста : дис. ... магистра филол. наук. — Сычуань, 2019.

12. 邵丽丽. 克雷洛夫寓言中的语言信息单位分析. 硕士研究生学位论文, 广东外语外贸大学, 2017。 Шао Лили. Анализ логоэпистемы в баснях И. А. Крылова : дис. ... филол. наук. - Гуандун, 2017.

13. 盛美娣. 读克雷洛夫寓言札记. 《语文学习》, 1957年第7期, 17-19页。Шэн Мэйди. Басни Крылова на мой взгляд // Изучение китайского языка. — 1957. — № 7. — С. 17-19.

14. 斯捷潘诺夫著, 何茂正、田宝石译. 《克雷洛夫传》.哈尔滨 : 黑龙江人民出版社, 1983年, 339页。Степанов Н. Л. И. А. Крылов. Жизнь и творчество / в пер. Хэ Маочжэна и Тянь Баоши. Харбин : Хэйлунцзянское народное изд-во, 1983. - 339 с.

15. 谭旭东. 寓言文学的传统与创新.《贵州民族报》，2012年2月17日，第C03版。 Тань Сюйдун. Традиция и инновация басни // Гуйчжоуский народ. - 2012, 17 февр.

16. 王莉佳. 浅析克雷洛夫矢于 1812 年战争的寓言及克雷洛夫寓言的特点. 硕士研究生学位论 文, 辽宁大学, 2013年。Ван Лицзя. Характеристика басен И. А. Крылова вообще и басен Крылова о войне 1812 года в частности : дис. магистра филол. наук. - Ляонин, 2013.

17. 吴岩. 译后记. 《克雷洛夫寓言》, 南昌 : 江西人民出版社, 1979年, 330页。У Янь. Послесловие к переводу // Крылов И. А. Басни Крылова. — Наньчан : Цзянсиское нар. изд-во, 1979. — 330 с. 
18. 徐双双. 顺应论视角下的克雷洛夫寓言翻译研究. 硕士研究生学位论文, 上海外国语大学, 2018年。 Сюй Шуаншуан. О переводе басен И. А. Крылова на китайский язык с точки зрения теории адаптации : дис. магистра филол. наук. - Шанхай, 2018.

19. 赵桂一. 语用学视角下感情评价色彩词语特点的分析一以克雷洛夫寓言译本为例. 硕士 研究生学位论文, 厦门大学, 2014。Чжао Гуйи. Анализ эмоционально-оценочной окраски слов с точки зрения прагматики на примере перевода басен И. А. Крылова : дис. магистра филол. наук. - Сямэнь, 2014.

\section{References}

1. 陈次园. 试译克雷洛夫寓言诗六首.《苏联文学》, 1985年第5期, 126-130页。Chen Ciyuan. Translation of six fables by I. A. Krylov into Chinese. Soviet Literature. 1985, no. 5, pp. 126-130.

2. 陈建华. 从《俄人寓言》到《克雷洛夫寓言》一一谈谈中国早期的俄国文学译介. 《中国比 较文学》, 1996年第1期, 90-100页。Chen Jianhua. From «Russian fable» to “Krylov's fables” — about the early stage of Russian literature distribution in China. Chinese Comparative Literature. 1996, no. 1 , pp. $90-100$.

3. 杜雷林著, 梦海译. 《克雷洛夫评传》.上海：时代出版社, 1950年, 95页。Durylin S. N., trans. Meng Hai, I. A. Krylov. A brief sketch of life and creativity. Shanghai, Times Press, 1950, 95 p.

4. 韩桂良. 克雷洛夫寓言是诗一一读辛译《克雷洛夫寓言集》的几点感想. 《外国语》 1994 年第1期, 第65-70页。Han Guiliang. Krylov's fables are poetry — review of the "Collection of Krylov's fables" translated by Xin Weiai. Foreign Languages. 1994, no. 1, pp. 65-70.

5. 何静翔, 杨万毅. 柳宗元与克雷洛夫寓言作品比较研究的意义综述. 《昌吉学院学报》, 2011年第1期, 43-46页。He Jingxiang, Yang Wanyi. The significance of the comparative study of Liu Zongyuan and Krylov's fables. Bulletin of the Changji Institute. 2011, no. 1, pp. 43-46.

6. 何茂正. 我译克雷洛夫寓言全集. 《俄罗斯文艺》, 2000年第1期, 51-56页。He Maozheng. How I translated collection of Krylov's fables. Russian Literature and Art. 2000, no.1, pp. 51-56.

7. 何世英. 译后记. 《克雷洛夫寓言诗集》, 广州 : 花城出版社, 1983年, 403页。He Shiying. Afterword to the translation. Krylov I. A. Collection of Krylov's Fables. Guangzhou, Huacheng Press, 1983, $403 \mathrm{p}$.

8. 黄弗同. 满纸荒唐言, 一把辛酸泪一一读克雷洛夫寓言散记.《外国文学研究》, 1979年第2 期, 20-23页。Huang Futong. Comparison of Krylov's fables with Cao Xueqin's "Dream of the Red Mansion”. Research on Foreign Literature. 1979, no. 2, pp. 20-23.

9. 李春雨. 克雷洛夫的戏剧创作 (译序). 《法国侯爵一一克雷洛夫剧作集》, 成都: 四川人 民出版社, 2020年, 572页。 Li Chunyu. Krylov's theatrical creation (Foreword). Krylov I. A. Collection of Krylov's Drama. Chengdu, Sichuan People's Publishing House, 2020, 572 p.

10. 马琳. 克雷洛夫戏剧创作的喜剧性. 《戏剧文学》，2020年第8期，93-103页。 Ma Lin. The comic nature of Krylov 's plays. Theatrical Literature. 2020, no. 8, pp. 93-103.

11. 谯妮楠. 克雷洛夫寓言汉译的语篇翻译研究. 硕士研究生学位论文, 四川外国语大学, 2019。 Qiao Ninan. Research of translation of I. A. Krylov's fables into Chinese from the perspective of text theory. Dissertation for the master's degree in literature. Sichuan International Studies University, 2019.

12. 邵丽丽. 克雷洛夫寓言中的语言信息单位分析. 硕士研究生学位论文, 广东外语外贸大学, 2017. Shao Lili. Analysis of linguistic units in the fables of I. A. Krylov. Dissertation for the master's degree in literature. Guangdong University of Foreign Studies, 2017.

13. 盛美娣. 读克雷洛夫寓言札记. 《语文学习》, 1957年第7期, 17-19页。 Sheng Meidi. Reading Krylov's fables. Learning Chinese. 1957, no. 7, pp. 17-19.

14. 斯捷潘诺夫著, 何茂正、田宝石译.《克雷洛夫传》.哈尔滨：黑龙江人民出版社, 1983年, 339 页。Stepanov N. L., trans. He Maozheng, Tian Baoshi. I. A. Krylov. Life and work. Harbin, Heilongjiang People's Publishing House, 1983, 339 p.

15. 谭旭东. 寓言文学的传统与创新. 《贵州民族报》, 2012年2月17日, 第C03版。 Tan Xudong. The tradition and innovation of fable. Guizhou people's Daily. 17.02.2012, p. C03. 
16. 王莉佳. 浅析克雷洛夫矢于1812年战争的寓言及克雷洛夫寓言的特点. 硕士研究生学位论 文, 辽宁大学, 2013年。Wang Lijia. Characteristics of I. A. Krylov's fables in General and Krylov's fables about the war of 1812, in particular. Dissertation for the master's degree in literature. Liaoning University, 2013.

17. 吴岩. 译后记. 《克雷洛夫寓言》, 南昌 : 江西人民出版社, 1979年, 330页。Wu Yan. Afterword to the translation. Krylov I. A. Krylov's fables. Nanchang, Jiangxi People's Publishing House, $1979,330 \mathrm{p}$.

18. 徐双双. 顺应论视角下的克雷洛夫寓言翻译研究. 硕士研究生学位论文, 上海外国语大学, 2018年。Xu Shuangshuang. About the translation of I. A. Krylov's fables into Chinese from the point of view of adaptation theory. Dissertation for the master's degree in literature. Shanghai Foreign Studies University, 2018.

19. 赵桂一. 语用学视角下感情评价色彩词语特点的分析一以克雷洛夫寓言译本为例. 硕士 研究生学位论文, 厦门大学, 2014。Zhao Guiyi. Analysis of the emotional and evaluative coloring of words from the point of view of pragmatics on the example of the translation of Krylov's fables. Dissertation for the master's degree in literature. Xiamen University, 2014.

\section{Информация об авторе}

Ли Чуньюй - кандидат филологических наук, старший преподаватель Института иностранных языков Сямэньского университета. Почтовый адрес: КНР, 361005, пров. Фуцзянь, г. Сямэнь, р-н Сымин, пр. Сыминнаньлу, д. 422. Тел.: 1595-927-2892.

\section{Information about the author}

Li Chunyu - Ph. D. (Philology), Assistant professor, Foreign Languages College, Xiamen University. Postal address: Xiamen University, Si Ming Campus, 361005, Fujian, China. Tel.: 1595-927-2892.

Статья поступила в редакциию 11.04.2021;

одобрена после рецензирования 25.04.2021;

принята к публикации 26.04.2021.

Submitted 11.04.2021;

approved after reviewing 25.04.2021;

accepted for publication 26.04.2021. 


\title{
РАЗДЕЛ V \\ К 8О-ЛЕТИЮ НАЧАЛА ВЕЛИКОЙ ОТЕЧЕСТВЕННОЙ ВОЙНЫ
}

Иностранные языки в высшей школе. 2021. № 2 (57). С. 108-117.

Foreign Languages in Tertiary Education. 2021;2(57):108-117.

Научная статья

УДК 81'255.4

DOI: $10.37724 /$ RSU.2021.57.2.010

\section{Выразительность текста \\ в парадигме «поэтика - поэзия - перевод»}

\author{
Яков Моисеевич Колкер ${ }^{1}$, Елена Сергеевна Устинова ${ }^{2}$ \\ ${ }_{1,2}$ Рязанский государственный университет имени С. А. Есенина, Рязань, Россия \\ ${ }^{1}$ kolker1937@yandex.ru \\ 2 e.ustinova@365.rsu.edu.ru
}

Аннотация. В статье с переводческой позиции рассматривается эмоциональный эффект, производимый короткими стихотворениями о Великой Отечественной войне. Предметом исследования является выразительность, понимаемая не как экспрессивность тропов, фигур речи или авторских окказионализмов, а как эффект воздействия на читателя, достигаемый всей совокупностью средств письменного художественного текста. Особое внимание уделяется неброским проявлениям выразительности, приобретающим смысл только в конкретном тексте. Исследуется взаимодействие и взаимозависимость лексических, синтаксических, фонетических и пунктуационных способов выразительности, их смысловой потенциал, пути достижения компрессии, а также способы передачи создаваемого впечатления в переводе. Авторы предлагают свое видение основной задачи поэтики в отношении поэтических произведений с присущей им компрессией, где любая самая мелкая единица текста, включая знаки пунктуации, участвует в создании тона, авторского голоса и производимого эмоционального впечатления. Исследование выполнено на материале четырех стихотворений отечественных классиков середины XX века А. А. Ахматовой, А. Т. Твардовского, К. М. Симонова и А. А. Тарковского. Переводы стихотворений на английский язык сделаны авторами статьи.

Ключевые слова: поэтика, выразительность, голос автора, тон, компрессия, контраст, экспликация, неприметность, цельность впечатления.

Для цитирования: Колкер Я. М., Устинова Е. С. Выразительность текста в парадигме «поэтика поэзия - перевод // Иностранные языки в высшей школе. 2021. № 2 (57). С. 108-117. DOI: 10.37724/ RSU.2021.57.2.010.

Original article

\section{The Affective Aspect of the "Poetics - Poetry — Translation" Paradigm}

Yakov M. Kolker ${ }^{1}$, Elena S. Ustinova ${ }^{2}$

${ }_{1,2}$ Ryazan State University named for S. A. Esenin, Ryazan, Russia

${ }^{1}$ kolker1937@yandex.ru

2 e.ustinova@365.rsu.edu.ru

Abstract. The paper examines, through the lenses of a translator, the emotional effect produced by short poems about the Great Patriotic war. The study focuses on the notion of expressiveness, but not the kind of expressiveness that catches the eye with original tropes and figures of speech or the author's nonce-words. It is

(C) Колкер Я. М., Устинова Е. С., 2021 
treated as the effect produced upon the reader by a whole array of descriptive and expressive means employed in written texts. The authors examine the interaction and interdependence of lexical, syntactical, and, especially, less conspicuous phonetic and punctuation means of meaning-making. It is stated that a compressed and unaffected manner of expression in poetry may have a far greater impact than an excessive use of tropes or most inventive nonce-words. The authors suggest their vision of poetics in reference to poetry, with its tendency for compression, where every component, however unobtrusive (like punctuation signs, for instance), participates in creating the right tone, in rendering the poet's voice and producing the intended emotional impression. The research is based on four Russian poems written in the 1940's-1970's by Anna Akhmatova, Alexander Tvardovsky, Konstantin Simonov, and Arseny Tarkovsky. The translations belong to the authors of the paper.

Keywords: poetics, inconspicuous expressiveness, poet's voice, tone, compression, contrast, explication, comprehensive impression.

For citation: Kolker Ya. M., Ustinova E. S. The Affective Aspect of the "Poetics - Poetry Translation" Paradigm. Foreign Languages in Tertiary Education. 2021;2(57):108-117. (In Russ.). DOI: 10.37724/RSU.2021.56.1.012.

В статье исследуется проблема выразительности слова в художественном тексте, прежде всего в поэтическом, и в его переводе. Теория художественной литературы еще со времен Аристотеля обозначается филологами — литературоведами и лингвистами - термином «поэтика». Большой энциклопедический словарь трактует поэтику как «раздел теории литературы, изучающий систему средств выражения в литературных произведениях» [БЭС, 2000]. Б. В. Томашевский высказывает аналогичное мнение: «Задачей поэтики (иначе теории словесности или литературы) является изучение способов построения литературных произведений. Объектом изучения в поэтике является художественная литература. Способом изучения является описание и классификация явлений и их истолкование» [Томашевский, 1999]. В такой трактовке поэтика мало чем отличается от стилистики. Но стилистика не дает системы единиц, определяющих все уровни создания художественного высказывания на письме. Стилистика носит «точечный», а не всеобъемлющий характер, определяет роль каждого средства, но не объединяет их в единой парадигме выразительных средств.

Б. В. Томашевский подчеркивает мысль, ранее высказанную Р. Якобсоном, о сосредоточенности художественного произведения не на внешней «идее», а на самом себе: «Интерес, пробуждаемый в нас поэзией, и чувства, возникающие при восприятии поэтических произведений, психологически родственны интересу и чувствам, возбуждаемым восприятием... музыки, живописи, танца, орнамента» [Томашевский, 1999].

Р. Якобсон и уподобляет, и противопоставляет воздействие художественного слова впечатлению, производимому другими видами искусства: "Poetics deals primarily with the question, "What makes a verbal message a work of art? " Because the main subject of poetics is the differentia specifica of verbal art in relation to other arts and in relation to other kinds of verbal behaviour, poetics is entitled to the leading place in literary studies" [Jacobson, 1987, p. 63]. С одной стороны, Якобсон считает, что поэтика не ограничивается словесным искусством, а с другой стороны, поэтика — это лингвистическая наука.

Поэтика, по большому счету, есть наука о системе выразительных средств. В отличие от поэтической функциии, подчиняющей себе в художественной речи другие функции языка, поэтика как наука, изучающая воздействие художественного текста на реципиента, учитывает взаимодействие всех функций языка. Говоря о близости лингвистических дисциплин, занимающихся изучением текстов, Ц. Тодоров подчеркивал, что «поэтика примыкает к семиотике, объединяющей весь цикл исследований, отправной точкой которых является понятие знака» [Тодоров, 1975, с. 46]. Но не лингвистикой единой жива поэтика, а очень сложными взаимоотношениями между языком и социально-психологическими, логическими и другими факторами, где лингвистическая составляющая пересекается с эстетической, социокультурной и этической. 
Роль этического фактора особенно велика, когда речь идет о такой теме в поэзии, как Великая Отечественная война, оставившая непреходящий след в памяти народа, в его духовном опыте. Поэзия, в отличие от прозы, в силу необходимости компрессии не может полагаться на детальное воссоздание событий, чтобы обеспечить эмоциональный отклик. Поэзия может обеспечивать смысловую емкость за счет своих приемов, связанных с метафоричностью или метонимичностью языка, когда одна художественная деталь воссоздает в воображении читателя всю картину. Именно это качество поэзии имеет в виду Л. И. Тимофеев, приводя в книге «Слово о стихе» следующие высказывания мастеров слова, где, по сути, оба поэта и великий прозаик выражают одну и ту же мысль:

- «Стихи пишутся затем, чтобы сказать больше, чем можно в прозе». - В. Брюсов.

- «Пришло бы место, где моя мысль потребовала бы больше сжатости, силы, законченности, и вышли бы стихи». - Л. Толстой.

- «Мне нужен... сжатый язык, почти поговорочный в прозе, или - стихотворение». - А. Блок [Тимофеев, 1982, с. 3].

Компрессия дает возможность выразительности стиха без излишней патетики слога, с ёмкостью образности, не перегруженной метафорами, и тем самым развивает у читателя новое видение, помогает «находить общий язык с изменяющимся миром»: 'Poets, by creating new ways of seeing and perceiving, help to create the new ways of thinking that bring us to terms with the changing world" (Hayakawa, Hayakawa, 1990, p. 142). Поэтому в стихе искренность поэтического тона, искренность голоса поэта самой своей правдивостью создает выразительный художественный образ.

Понятие «выразительность», на первый взгляд, передается и внутриязыковым, и межъязыковым переводом как «экспрессивность» (expressiveness). Но это есть сугубо стилистическое понимание выразительности как использования тропов, фигур речи или стилистического регистра, далекого от нейтральности. В таком понимании экспрессивность всегда эксплицитна и привлекает внимание читающего. Но в данном случае под выразительностью мы имеем в виду не стилистическую экспрессивность, а то, что точнее всего передается понятием «смысловая значимость, смыслообразующая роль» (meaning-making). Тон стиха - это смыслообразующий фактор, то есть он выразителен, даже если абсолютно нейтрален. Именно верный тон, искренний голос поэта и даже свойственные разговорной речи плеонастические повторы так подкупают в стихотворении Александра Твардовского «Я знаю, никакой моей вины...»:

***
Я знаю, никакой моей вины
В том, что другие не пришли с войны,
В том, что они - кто старше, кто моложе -
Остались там, и не о том же речь,
Что я их мог, но не сумел сберечь, -
Речь не о том, но всё же, всё же, всё же...

Поэт разговаривает с читателем, как бы «не заботясь о форме», он делится чувством невольной вины со своими современниками, такими же ветеранами, как и он, - и тем самым вызывает то же чувство у современного читателя, родившегося после войны. Выразительность стихотворения - не от стилистических приемов, а от самого дыхания стиха: ритма повторов, пауз, попыток «неискушенного в риторике» человека высказать то, что давно наболело на душе. Основным выразительным средством является пауза, маркируемая тире, запятыми, многоточием: именно благодаря ей поэт пишет, как дышит, и именно благодаря ей в финале у исповедующегося (не только перед читателем!) и у читателя перехватывает дыхание. 
В переводе важно воссоздать тот же разговорный исповедальный тон. Но отдаленность читателя во времени от той грозной эпохи дает переводчику право на усиление образа погибших. Нейтральная фраза «...они - кто старше, кто моложе - // Остались там» в переводе трансформируется в метафору. Погибшие всё еще на поле боя, их сердца переполнены «благородной яростью», им еще предстоит выиграть битву:

I am not guilty, though hurt and sore,

That other soldiers didn't come from war,

That they are there, feeling deadly rage

And having still a mortal fight to wage.

I could not save them, though I had the will.

I'm not to blame. And still, and still, and still...

Пер. Я. Колкера

Этим строкам Александра Твардовского созвучно по теме стихотворение Арсения Тарковского «Суббота 21 июня», датированное годом окончания войны. Тарковский, военный корреспондент, участник боевых действий, потерявший на войне ногу, представляет фантастическую ситуацию: возможность вернуться в прошлое накануне войны и предостеречь от грозящей опасности тех, чья судьба ему уже известна. В стихотворении причудливо переплетаются мечта о такой возможности - и будто бы сбывшееся погружение в прошлое, взволнованный монолог о шансе на спасение - и безучастность прохожих (возможно потому, что они не видят и не слышат лирического героя, будучи из другого времени), послевоенная реальность - и жутковатый финал, где лирический герой забывает о своей миссии и обречен остаться в прошлом, чтобы вновь пережить войну... Стихотворение повествовательно, причем один и тот же нарратор создает внешнюю канву повествования (погружение в прошлое) и внутреннюю (драматический монолог - глас вопиющего в пустыне). Выразительность стихотворения в равной мере достигается эмотивно-побудительной лексикой (надежда на спасенье, предупредить, необходимо, иди сюда, я знаю, мне все известно) и контрастом между взволнованным монологом и отсутствием реакции на него, а также забвением своей провидческой миссии. Этот последний поворот сюжета, нередкий у писателей-фантастов, звучит особенно зловеще в стихотворении, где игра воображения переплетается с реальностью. Выразительность поддерживается и целым рядом контрастов внутри большинства двустиший (выживет - умрет в плену; окажется героем - будет расстрелян; вражеские солдаты в Сталинграде - русская пехота штурмует Берлин; я говорю - не слушают).

\section{Суббота 21 июня}

Пусть роют щели хоть под воскресенье.

В моих руках надежда на спасенье.

Как я хотел вернуться в до-войны, Предупредить, кого убить должны.

Мне вон тому сказать необходимо: «Иди сюда, и смерть промчится мимо».

Я знаю час, когда начнут войну, Кто выживет, и кто умрет в плену,

И кто из нас окажется героем, И кто расстрелян будет перед строем, 
И сам я видел вражеских солдат, Уже заполонивших Сталинград,

И видел я, как русская пехота Штурмует Бранденбургские ворота.

Что до врага, то все известно мне, Как ни одной разведке на войне.

Я говорю - не слушают, не слышат, Несут цветы, субботним ветром дышат,

Уходят, пропусков не выдают, В домашний возвращаются уют.

И я уже не помню сам, откуда

Пришел сюда и что случилось чудо.

Я все забыл. В окне еще светло,

И накрест не заклеено стекло.

Основная трудность перевода состоит в том, чтобы избежать монотонного ритма двустиший. Поэт чередует пары строк с мужской и женской рифмой. Поскольку для английского стиха женские рифмы не типичны, их отсутствие вполне компенсируется рифмами-дифтонгами и особенно трифтонгами, акустически удлиняющими строку. И если в пределах драматического монолога это только вопрос благозвучия в противовес монотонности ритма, то как минимум в двух двустишиях растяжка строки и замедление ритма необходимы в целях смысловой выразительности (meaning-making) - в предпоследнем двустишии, где герой погружается в «забвение будущего», а также - и это самое важное в девятом двустишии, где всё дышит покоем, летним теплом и беззаботностью. В переводе почти в каждом слове этого двустишия - либо дифтонг, либо долгий гласный звук, то есть смысл в равной мере выражен лексически и фонетически.

Другая трудность - возможно, неточное выражение Тарковского: «Уходят, пропусков не выдают...». Очевидно, поэт имел в виду, что в этот последний предвоенный день можно было гулять, где вздумается и сколько вздумается, без необходимости предъявлять свой пропуск. Поэтому в переводе фразу необходимо эксплицировать с помощью добавления. Для читателей, незнакомых с бытом и порядками военного времени, желательно детализировать суровый уклад жизни, о котором мирный город пока не ведает, например: «Нет ни комендантского часа, ни пропусков, ни военного положения...».

Кроме того, для иностранцев дата «суббота, 21 июня» может быть лишена импликации, понятной всем нашим соотечественникам. И это неудивительно: ведь и мы зачастую незнакомы с точными датами, вызывающими ассоциации у других народов. Пример из собственного опыта межкультурного общения: в неформальной беседе американский коллега, рассказывая о скоропостижной смерти своего отца, добавил: "Just think that, of all days, it should have happened on the $7^{\text {th }}$ of December!" - «И подумать только, что это произошло именно 7 декабря». Видя недоумевающий взгляд, он пояснил: «День нападения японцев на Перл-Харбор». Поэтому в нашем переводе англоязычное название стихотворения называет не дату, а ее трагический смысл - «Накануне войны».

\section{On the Eve of War}

Dig hidey holes before it is too late!

Salvation in my hands, I can avert your fate.

If I could only dive into pre-war

And warn all those who soon would be no more! 
I'd say to men, while they were still alive,

"Come here to dodge the bullet - and survive!"

I know the very hour of the attack,

I know who'll perish and who will come back,

I know whose valour will be crowned with fame,

And who'll be sentenced to a death of shame.

I saw the times of bitterness and woe,

Like Stalingrad invaded by the foe,

And witnessed Russian soldiers storming in

To seize the Nazi stronghold in Berlin.

I can disclose the foe's strategic plan

Far better than a secret service man.

...They pay no heed - those final peaceful hours

Are full of warmth and breeze and smell of flowers.

No curfew, need for passes, martial law, -

One's home the safest place for ever more!

...And suddenly I cease to be aware

Of my fantastic transfer from elsewhere.

My mind is blank. The lingering day will pass.

There's no tape yet across the window-glass.

\section{Пер. Е. Устиновой}

На ту же тему - вторжение войны в мирную жизнь - написано стихотворение Константина Симонова «Тот самый длинный день в году». Но тон стихотворения - иной. Это взгляд на события многолетней давности и их неизгладимый след в памяти живых. Это реквием по погибшим на войне и по тем, кто пополняет этот скорбный список. Среди них и ветераны, пережившие войну, но ушедшие из жизни до срока, и те, чьи останки на полях сражений много лет ждали опознания и достойного погребения. А «лишняя» строка в последней строфе - клятва свято хранить память о них. Стихотворение написано в 1971 году.

Тот самый длинный день в году

С его безоблачной погодой

Нам выдал общую беду

На всех, на все четыре года.

Она такой вдавила след

И стольких наземь положила,

Что двадцать лет и тридцать лет

Живым не верится, что живы.

А к мертвым, выправив билет,

Все едет кто-нибудь из близких,

И время добавляет в списки

Еще кого-то, кого нет...

И ставит,

ставит

обелиски. 
Фраза «выправив билет», скорее всего, означает, что близкий человек захоронен гдето очень далеко - возможно, за пределами отечества, и путь туда сопряжен с трудностями. «Выправить» документ издавна означало преодолеть некоторые трудности, чтобы добиться оформления документа. В переводе это устаревающее слово компенсировано выражением духовной потребности посетить место упокоения близкого человека. Время - олицетворенный «персонаж» стихотворения, и в переводе олицетворение подчеркивается заглавной буквой и эпитетом “old".

Самая последняя строка разбита на три - и опять ритм становится смыслообразующим фактором, в дополнение к повтору «ставит». Выразительности завершающей строки способствует и многоточие, ибо Времени предстоит поставить еще немало обелисков, ведь недаром А. В. Суворову приписывают такие слова: «Пока не будет предан земле последний погибший солдат — война не окончена!» ${ }^{1}$.

Лексика стихотворения подчеркнуто обыденна. Ее можно отнести к общеупотребительно-разговорному регистру (выдал общую беду, наземь положила, выправив билет). К. Симонов позволяет себе лишь поэтический образ времени, ведущего списки и воздвигающего монументы. Минимизация метафоричности и исключение выспренности - это и есть ключ поэта к выразительности стихотворения.

Приводим его перевод:

That day, the longest of the year, With bluest sky and warmest sun, Brought a disaster - mad, severe, Engulfing all and everyone.

It left its mark on homes bereaved, On countless graves, young talents gone...

And we, the living, can't believe That we survived, that life goes on.

And, urged by instincts of the soul, We seek our dead, forever missed. Old Time keeps record of the list Adding new names to the sad toll ... And keeps erecting obelisks.

\section{Пер. Е. Устиновой}

Четвертое, и последнее, стихотворение принадлежит Анне Ахматовой. Оно отличается от трех предыдущих, поскольку его предназначение - убеждать, призывать и объединять слушателей. Это редкий случай, когда поэзия звучит откровенно побудительно, то есть на первый план выходит функция языка, которую И. А. Арнольд называет волюнтативной [Арнольд, 2010, с. 15] и которая организует взаимодействие остальных функций эмотивной, контактоустанавливающей, эстетической. Стихотворение написано в 1942 году в блокадном Ленинграде. И слово великой поэтессы о великом русском Слове само по себе звучало как призыв к мужеству.

1 «Пока не похоронен последний солдат...». URL : https://nvo.ng.ru/nvo/2018-09-13/1_1013_excavations.html (дата обращения: 16.05.2021). 


\section{Анна Ахматова}

\section{Мужество}

Мы знаем, что ныне лежит на весах

И что совершается ныне.

Час мужества пробил на наших часах, И мужество нас не покинет.

Не страшно под пулями мертвыми лечь, Не горько остаться без крова, И мы сохраним тебя, русская речь, Великое русское слово.

Свободным и чистым тебя пронесем, И внукам дадим, и от плена спасем Навеки.

В этой коммуникативной ситуации, где к слушателям обращалась звучащая речь, был необходим высокий слог, - высокий, но не выспренний. Самую простую русскую речь Ахматова превращает в гимн грядущей победе. И еще нужна была лаконичность и емкость поэтического высказывания. Призыв сохранить родную речь звучит, как колокол. Поэтому поэтесса избрала амфибрахий с его замедленной торжественностью.

Знаменательно, что и Ахматова, и Симонов используют один и тот же риторический прием - отделенную от структуры стиха последнюю строку. У Ахматовой слово «навеки» звучит словно клятва, повторяемая тысячами голосов. Размеренность ритма, оттененная завершением «Навеки», создает впечатление спокойной уверенности в победе.

Это стихотворение можно переводить почти дословно. И всё же иногда стремление к точности может подвести переводчика. Если вторую строку «И что совершается ныне» передавать дословно (“And what is happening now”), то замена общеупотребительно-литературного слова «совершается» на нейтральное "happening” обеспечивает лексическую точность, но изменяет точности тона автора. Теряется многозначность смысла. Строка «И что совершается ныне» относится к чудовищному преступлению гитлеровцев против мирных жителей города и одновременно подчеркивает духовную стойкость измученных блокадой, но не сломленных ленинградцев. И эхо вечевого колокола было слышно по всей стране. Поэтому в переводе вместо буквализма "what is happening now" дается строка "in times of disaster and chaos", суммирующая и трагедию блокады, и нелегкую ситуацию первого года войны для всей страны, и готовность народа вынести все тяготы войны во имя победы.

\section{Anna Akhmatova}

\section{Courage}

We know what scales our fortitude weigh In times of disaster and chaos.

The hour of courage our clock has proclaimed, And courage will never betray us.

We are not afraid of the bullets and grave, That roofs might burn down to ashes.

It is our Word we are ready to save,

The tongue that is dear and precious.

The Word as the symbol of Russia has risen.

We'll save it from slavery, torture, and prison

Forever. 
Таким образом, поэтика стиха, как и поэтика художественной прозы, изучает выразительность текста как органичное единство всех его компонентов. Выразительность текста состоит не только и даже не столько в обилии свежих тропов, фигур речи, авторских неологизмов и других броских приемов привлечения внимания, поэтика изучает и ту неприметную выразительность, которая на письме почти незаметна глазу и может выражаться в звуковой гармонии или нарочитой дисгармонии, в ускорении или замедлении темпа, в паузах, выражаемых знаками препинания, в неожиданной смене длины предложения, в оборванности фразы и т. д. В стихотворении, в отличие от прозы, эти малозаметные выразительные средства часто имеют не локальный, а общий смыслообразующий эффект. Поэтому перевод, необязательно сохраняя их с буквальной точностью, обязан воссоздавать, пусть даже иными средствами, текстообразующий эффект «неприметной выразительности».

Соответственно задача поэтики, в отличие от стилистики, состоит в создании «единой теории поля» применительно к художественному тексту, где каждая единица текста от запятой до центрального образа - есть часть смыслового единства с его благородной естественностью и где нельзя ничего ни убавить, ни прибавить, не нарушив цельности производимого впечатления.

\section{Список источников}

1. Арнольд И. В. Стилистика. Современный английский язык. - М. : Флинта : Наука, 2010. $-384 \mathrm{c}$.

2. Большой энциклопедический словарь (БЭС), 2000. — URL: https://dic.academic.ru/dic.nsf/ enc3p/242178 (дата обращения: 25.05.2021)

3. Тимофеев Л. И. Слово в стихе. - М. : Советский писатель, 1982. - 343 с.

4. Тодоров Ц. Поэтика // Структурализм: за и против : сб. ст. - М. : Прогресс, 1975. — C. $37-113$.

5. Томашевский Б. В. Теория литературы. Поэтика : учеб. пособие. - М. : Аспект Пресс, 1999. - 334 c. - URL : https:/www.textologia.ru/literature/teoria-literatury/literaturovedenienauka/poetika-opredelenie-zadachi-osobennosti/1772/?q=471\&n=1772 (дата обращения: 20.04.2021)

6. Hayakawa S. I., Hayakawa Alan R. Language in Thought and Action. - Orlando ; Austin ; New York; San Diego ; London : First Harvest edition, 1990. — 196 p.

7. Jacobson R. Language in literature / ed. by K. Pomorska, S. Rudy. - Cambridge (Massachusetts) ; London (England) : The Belknap Press of Harvard University Press, 1987. — 548 p.

\section{References}

1. Arnold I. V. Stilistika. Sovremennyi angliyskiy yazyk [Stylistics. Modern English]. Moscow, Flinta, Science Publ., 2010, 384 p. (In Russian).

2. Big Encyclopedic Dictionary (BES), 2000. Available at : https://dic.academic.ru/dic.nsf/ enc3p/242178 (accessed 25.05.2021).

3. Timofeev L. I. Slovo v stikhe [The Word in a poem]. Moscow, Soviet Writer Publ., 1982, 343 p. (In Russian).

4. Todorov Tz. Poetics. Structuralism: za i protiv [Structuralism: For and Against]. Collection of papers. Moscow, Progress Publ., 1975, pp. 37-113. (In Russian).

5. Tomashevsky B. V. Teoriya literatury. Poetica [Theory of Literature. Poetics]. Moscow, Aspect Press Publ., 1999, 334 p. Available at: https://www.textologia.ru/literature/teoria-literatury/ literaturovedenie-nauka/poetika-opredelenie-zadachi-osobennosti/1772/?q=471\&n=1772 (In Russian). (accessed 20.04.2021).

6. Hayakawa S. I., Hayakawa Alan R. Language in Thought and Action. Orlando, Austin, New York, San Diego, London, First Harvest edition Publ., 1990, 196 p.

7. Jacobson R. Language in literature (Ed. by) K. Pomorska, S. Rudy. Cambridge, Massachusetts, London, The Belknap Press of Harvard University Press, 1987, 548 p. 


\section{Информация об авторах}

Колкер Яков Моисеевич - кандидат педагогических наук, профессор кафедры лингвистики и межкультурной коммуникации института иностранных языков Рязанского государственного университета имени С. А. Есенина, почетный работник высшего профессионального образования (РФ), член Союза российских писателей (отделение перевода - поэзия).

Устинова Елена Сергеевна - кандидат педагогических наук, доцент, кафедра лингвистики и межкультурной коммуникации, руководитель Центра глобального образования института иностранных языков Рязанского государственного университета имени С. А. Есенина, почетный работник высшего профессионального образования РФ. Почтовый адрес: 390000 , г. Рязань, ул. Свободы, д. 46. Тел. (раб.): 8 (4912) 21-57-23.

\section{Information about the authors}

Kolker, Yakov (Jacob) - Ph. D. (Language Teaching Methodology), Professor of Linguistics and Intercultural Communication Dpt., Institute of Foreign Languages, Ryazan State University named for S. A. Esenin, Merited Educator of Tertiary Education of the Russian Federation, Member of the Professional Organization "Union of Russian Writers" (poetry).

Ustinova, Elena - Ph. D. (Language Teaching Methodology), Associate Professor, Linguistics and Intercultural Communication Dpt., Head of Global Education Centre, Institute of Foreign Languages, Ryazan State University named for S. A. Esenin, Merited Educator of Tertiary Education of the Russian Federation. Postal address: 46 Svobody St., Ryazan, 390000, Russia. Tel.: (4912) 21-57-23.

Статья поступила в редакциюю 25.04.2021;

одобрена после рецензирования 30.04.2021;

принята к публикации 11.05.2021.

Submitted 25.04.2021;

approved after reviewing 30.04.2021;

accepted for publication 11.05.2021. 


\section{Требования к публикациям и правила представления рукописей авторами}

(The Requirements for publication are also available in English at: http://fljournal.rsu.edu.ru/en/)

Учредитель - Федеральное государственное бюджетное образовательное учреждение высшего образования «Рязанский государственный университет имени С.А. Есенина».

Журнал «Иностранные языки в высшей школе» выходит с 2004 года с периодичностью (с 2009 года) - один раз в три месяца.

Журнал зарегистрирован Федеральной службой по надзору за соблюдением законодательства в сфере связи, информационных технологий и массовых коммуникаций (Роскомнадзор) 20 марта 2018 года. Регистрационный номер ПИ № ФС 77-72456.

Подписной индекс журнала — № 55170 в каталоге «Объединенный каталог Пресса России».

Журналу присвоен международный стандартный серийный номер (ISSN) 2072-7607.

Журнал с 1 декабря 2015 года входит в перечень рецензируемых научных изданий, в которых должны быть опубликованы основные научные результаты диссертаций по филологии (языкознание) на соискание ученой степени кандидата наук и на соискание ученой степени доктора наук.

Начиная с 2021 года публикации бесплатны, при этом учредитель ограничивает количество печатных экземпляров, обеспечивая только обязательную рассылку и рассылку по подписке. Авторам бесплатно высылается электронный макет журнала, подготовленный к отправке в НЭБ (РИНЦ). Желающие приобрести печатный экземпляр могут заблаговременно оформить подписку на соответствующий квартал.

Журнал принимает статьи по методике преподавания иностранных языков, если они содержат лингвистическую составляющую: «исследование особенностей использования сопоставлений на разных уровнях, выявление особенностей восприятия, употребления, типичных лингвокультурных ошибок и особенностей использования в разных языковых общностях» (см. «Паспорта научных специальностей»: http://vak.ed.gov.ru/316).

Значительное внимание уделяется проблемам теории и практики перевода, в том числе художественного перевода.

Список специальностей научных статей, публикуемых в журнале «Иностранные языки в высшей школе»

\begin{tabular}{|l|l|c|}
\hline Индекс & \multicolumn{1}{|c|}{ Специцальности } & Науки \\
\hline 10.02 .20 & Сравнительно-историческое, типологическое и сопоставительное языкознание & филологические \\
\hline 10.02 .19 & Теория языка & филологические \\
\hline 10.02 .04 & Германские языки & филологические \\
\hline 10.02 .05 & Романские языки & филологические \\
\hline
\end{tabular}

В журнале публикуются статьи российских и зарубежных авторов на русском языке или на английском как языке межнационального общения. В порядке исключения возможна публикация на других ведущих европейских языках — немецком или французском.

\section{Условия и порядок приема публикаций}

1. Редакционный совет принимает к публикации статьи, отличающиеся высокой степенью научной новизны, теоретической и практической значимости и соответствующие тематике журнала. Научные статьи направляются на независимую экспертизу и при положительном заключении, являющемся основанием для публикации, включаются в очередной номер журнала в порядке поступления.

2. К публикации принимаются научные статьи, соответствующие этическим принципам опубликования научных работ (см. раздел на сайте www.fljournal.rsu.edu.ru «Этика научных публикаций»). 
3. Авторами статей могуг быть ученые-исследователи, докторанты, аспиранты, соискатели.

4. Для аспирантов и соискателей кандидатских диссертаций обязательно наличие отзыва научного руководителя.

5. Сведения об авторах представляются на русском и английском языках:

- фамилия, имя, отчество автора (полностью; буква «ё» не должна заменяться на «е»);

- ученая степень, звание, должность, место работы без сокращений (с точным, официальным названием кафедры, вуза, страны); для аспиранта либо соискателя - место учебы (кафедра, вуз), научная специальность предполагаемой защиты (для аспирантов и докторантов);

- наличие наград и почетных званий (по желанию);

- приблизительное количество научных публикаций (монографий, учебно-методических пособий, статей);

- основные направления научных исследований;

- средства оперативной связи в процессе подготовки статьи к печати: личная электронная почта, мобильный телефон, при наличии - WhatsApp (личные данные, кроме электронной почты, в журнале не публикуются).

6. Статьи должны быть оформлены в строгом соответствии с техническими требованиями.

7. Статьи присылаются по электронной почте на адрес e.ustinova@365.rsu.edu.ru. Отзыв научного руководителя (для аспирантов и соискателей) присылается по почтовому адресу: 390000, Рязань, ул. Свободы, д. 46, Рязанский государственный университет, Институт иностранных языков, Устиновой Елене Сергеевне. Электронный вариант отзыва научного руководителя присылается вместе со статьей как приложение в формате, воспроизводящем подпись и печать.

8. Окончательное решение о приеме научной статьи к публикации принимается редакционным советом журнала «Иностранные языки в высшей школе». Извещение о решении редакционной коллегии направляется автору.

\section{Требования к оформлению статей}

1. Индекс УДК. Для публикации статье должен быть присвоен классификационный индекс универсальной десятичной классификации.

2. Название статьи (на русском и английском языках) пишется строчными буквами, используя заглавные только там, где это необходимо. избегая аббревиатур и сокращений.

3. Аннотаџия (на русском и английском языках) объемом 100-300 слов, избегая использование аббревиатур и сокращений. Аннотация должна отражать цель исследования, его новизну, суть авторского видения проблемы, основные положения, выдвигаемые автором, и результаты. Англоязычная аннотация может представлять собой перевод русскоязычной аннотации, но может быть и более развернутой, чтобы создать у читателей, не владеющих русским языком, более полное впечатление о сути исследования и его результатах.

4. Ключевые слова (на русском и английском языках). Ключевые слова должны отражать основное содержание статьи, по возможности не повторять термины заглавия и аннотации, использовать термины из текста статьи, а также термины, определяющие предметную область и включающие другие важные понятия, которые позволяют облегчить и расширить возможности нахождения статьи средствами информационно-поисковой системы. Минимальный объем - 10 ключевых слов; ключевое словосочетание не должно превышать 5 слов. Ключевые слова и словосочетания разделяются (;) точкой с запятой. Недопустимо использование любых аббревиатур и сокращений.

5. Текст статьи. Рекомендуется деление статьи на основные части с помощью подзаголовков. Все аббревиатуры и сокращения должны быть развернуты при первом использовании. Недопустимо использование расставленных вручную переносов. Объем статьи с учетом информативности текста может варьироваться от 0,3 до 1,0 авторского листа, или от 12 до 40 тыс. знаков. В зависимости от материала произведения 1 авторский лист равен: для прозаического текста 40 тыс. печ. знаков, для стихотворного текста - 700 строк, для изобразительного материала - 
3 тыс. см ${ }^{2}$ площади изображений. Текст статьи следует оформлять в 1,5 интервала при шрифте 14 Times New Roman стилем «Строгий» Microsoft Office Word. Редакционный совет оставляет за собой право сокращать статью (по согласованию с автором) или рекомендовать автору расширить статью.

6. Таблицы и рисунки. Каждый рисунок должен быть пронумерован, подписан и сгруппирован (то есть не «разваливаться» при перемещении и форматировании). Таблицы и рисунки должны иметь порядковую нумерацию, при этом нумерация рисунков и таблиц ведется раздельно. В тексте статьи на таблицы и рисунки обязательно должны быть отсылки.

7. Список использованной литературы (источников) оформляется в соответствии с ГОСТ P 7.0.5-2008 «Библиографическая ссылка. Общие требования и правила составления».

7.1. Чтобы все авторы публикации были учтены в системе цитирования, необходимо в библиографическое описание вносить всех авторов.

7.2. Недопустимо сокращать название статьи, книги, отечественного журнала, кроме тех случаев, когда сокращение имеется в предписанном источнике информации. Название англоязычных журналов следует приводить в соответствии с общепринятыми сокращениями.

7.3. В периодических или продолжающихся изданиях указывается текущий номер и (в скобках) валовой, то есть номер с момента основания издания.

7.4. Во всех случаях, когда у цитируемого материала есть цифровой идентификатор (Digital Object Identifier - DOI), его необходимо указывать в самом конце библиографической ссылки. В этом случае электронный адрес опускается.

8. Библиографическая ссылка оформляется в соответствии с ГОСТ Р 7.0.5-2008 «Библиографическая ссылка».

8.1. Приветствуется наличие ссылок на иноязычные публикации зарубежных исследователей.

8.2. При ссылках на электронные ресурсы следует указывать дату обращения.

8.3 Ссылки на Википедию недопустимы.

9. References.

9.1. Список использованной литературы на латинице (References) составляется в порядке, полностью идентичном русскоязычному варианту.

9.2. При описании изданий без авторов (коллективных монографий, сборников, материалов конференций) указывается отв. редактор (под редакцией), но не более двух.

Ниже приведены примеры описания использованных источников (литературы) и References.

\section{Книги, монографии}

\begin{tabular}{|c|c|}
\hline Список литературы & References \\
\hline \multicolumn{2}{|c|}{ Несколько авторов } \\
\hline $\begin{array}{l}\text { Железняк Ю. Д., Петров П. К. Основы научно- } \\
\text { методической деятельности в физической культуре } \\
\text { и спорте : учеб. пособие для вузов. - Ростов н/Д : } \\
\text { Академия, 2002. - } 264 \text { с. }\end{array}$ & $\begin{array}{l}\text { Zheleznyak Iu. D., Petrov P. K. Osnovy nauchno- } \\
\text { metodicheskoy deyatel'nosti v fizicheskoy kul'ture } \\
\text { i sporte [Bases of scientific and methodical activity in } \\
\text { physical culture and sport]. Rostov-on-Don, Academy } \\
\text { Publ., 2002, } 264 \text { p. (In Russian). }\end{array}$ \\
\hline
\end{tabular}

\section{конференций) \\ Периодические издания (статьи из журналов, сборников научных трудов, материалов}

\begin{tabular}{|c|c|}
\hline Список литературы & References \\
\hline \multicolumn{2}{|c|}{ Несколько авторов } \\
\hline $\begin{array}{l}\text { Загайнов С. С., Митчелл П. Д. История развития } \\
\text { военных словарей-разговорников как малого ли- } \\
\text { тературного жанра // Вестник Тамбовского уни- } \\
\text { верситета. Сер.: Гуманитарные науки. - Тамбов, } \\
\text { 2016. - Т. 21, вып. } 11 \text { (163). - C. 46-51. DOI : } \\
\text { 10.20310/1810-0201-2016-21-11(163)-46-51. }\end{array}$ & $\begin{array}{l}\text { Zagaynov S. S., Mitchell P. D. The history of the } \\
\text { development of military phrase books as a small literary } \\
\text { genre. Vestnik Tambovskogo universiteta. Seriya } \\
\text { "Gumanitarnye nauki" [Tambov University Review. } \\
\text { Series "Humanities"]. 2016, vol. 21, no. } 11 \text { (163), } \\
\text { pp. 46-51. (In Russian). DOI: 10.20310/1810-0201- } \\
\text { 2016-21-11(163)-46-51. }\end{array}$ \\
\hline
\end{tabular}


Материалы конференций

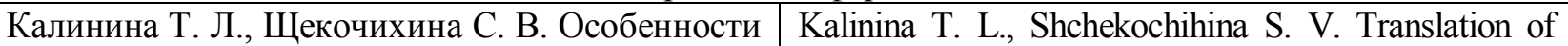
перевода парадоксов на материале перевода пьес Paradoxes in O. Wilde's plays. Ignatovich Yu. (ed.) О. Уайльда // Язык в различных сферах коммуни- Materialy Mezhdunarodnoj nauchnoj konferencii кации : материалы Междунар. науч. конф. / под "Yazyk v razlichnyh sferah kommunikacii" [Papers of ред. Т. Ю. Игнатович. - Чита : Забайкал. гос. ун-т, the International scholarly conference "Language in 2014. - C. 233-236.

Various Spheres of Communication"]. Chita, Zabaikal'sky State University Publ., 2014, pp. 233-236. (In Russian).

\section{Электронные ресурсы}

\begin{tabular}{|c|c|}
\hline Список литературы & References \\
\hline \multicolumn{2}{|c|}{ Электронный журнал } \\
\hline $\begin{array}{l}\text { Рыбаков С. Ю. Проблема духовности в педагоги- } \\
\text { ческом аспекте // Теория и практика общественно- } \\
\text { го развития. - 2014. - № 16. - URL : http:// } \\
\text { teoriapractica.ru/rus/files/arhiv_zhurnala/2014/16/ } \\
\text { pedagogics/rybakov.pdf (дата oбращения: 10.09.2016). }\end{array}$ & $\begin{array}{l}\text { Rybakov S. Iu. The problem of spirituality in the context } \\
\text { of education. Teoriya } i \text { praktika obshchestvennogo } \\
\text { razvitiya [The Theory and Practice of Social } \\
\text { Development]. 2014, vol. 16. (In Russian). Available } \\
\text { at: http://teoria-practica.ru/rus/files/arhiv_zhurnala/ } \\
\text { 2014/16/pedagogics/rybakov.pdf (accessed 10.09.2016). }\end{array}$ \\
\hline
\end{tabular}

Направляя статью для публикации в журнале «Иностранные языки в высшей школе», автор тем самым дает согласие на ее размещение на сайте журнала (https://fljournal.rsu.edu.ru/), a также в Российской научной электронной библиотеке на условиях открытого бесплатного полнотекстового доступа.

Электронные адреса и контактные телефоны:

e.ustinova@365.rsu.edu.ru (4912) 21-57-23, (4912)97-15-15 (доб. 1030) 


\title{
Иностранные языки в высшей школе
}

\author{
Научный журнал \\ Выпуск 2 (57)
}

\author{
2021 \\ Главный редактор
Колкер Яков Моисеевич \\ Редакторы иностранного текста: \\ Е. С. Устинова (английский язык) \\ Ван Цзиньлин (китайский язык) \\ Е. В. Игнатова (немецкий язык)
}

Редактор Ю. А. Филатова

Технический редактор Н. Н. Кулешова

Дата выхода в свет 23.06.2021. Цена свободная.

Гарнитура Microsoft YaHei, MingLiU, MS Gothic, MS Mincho, PMingLiU, SimSun, Times New Roman.

Бумага офсетная. Печать цифровая. Формат 60х84\% $1 / 8$.

Усл. печ. л. 14,18. Уч.-изд. л. 10,0. Заказ № 64. Тираж 200 экз.

Федеральное государственное бюджетное образовательное учреждение высшего образования

«Рязанский государственный университет имени С. А. Есенина»

Адрес издателя:

390000, г. Рязань, ул. Свободы, 46

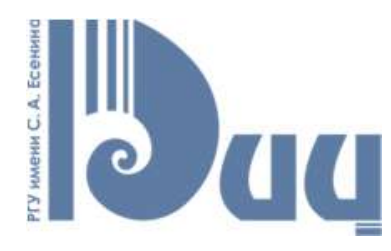

Адрес типографии:

Редакционно-издательский центр РГУ имени С. А. Есенина

390023, г. Рязань, ул. Ленина, 20а 